\title{
China's Business Reforms
}

China's recent economic reforms have led to impressive growth, and an unprecedented enthusiasm for establishing foreign enterprises in China. Since 1993, China has been the second largest recipient of foreign direct investment in the world after the USA and is now considered to be the world's third biggest economy after the USA and Japan. Its greater economic integration with the rest of the world, especially since its accession to the World Trade Organisation (WTO), has further accelerated its marketoriented economic reforms. China is now opening its protected markets and beginning to submit to the rule of international law. This ongoing transition and increasing participation in the world economy has resulted in significant changes in human resource, management and social welfare practices in China's enterprises. The book examines the key areas, all of which are linked, where China is grappling with institutional reforms as it opens up to the outside world - state-owned enterprise reform; capital markets and financial reform; human resources and labour market reform; social welfare reform; and China's accession to the WTO and the growth of the private sector.

Russell Smyth is Professor of Economics and Director of the Asian Business and Economics Research Unit, Monash University. His research interests include Chinese economic reform, law and economics and applied time series econometrics. He has published widely in these areas. He is Editor of Economic Papers, the policy journal of the Economic Society of Australia and Associate Editor of Asia Pacific Law and Economics Review.

On Kit Tam is Professor and Associate Dean International, Faculty of Business and Economics, Monash University. He is Co-Director of the Monash Governance Research Unit, and Director of China Research Center, Monash Asia Institute. His research interest is in corporate governance, China's economic reform, financial development and foreign investment policy.

Malcolm Warner is Professor and Fellow, Wolfson College and Senior Research Associate, Judge Institute of Management, University of Cambridge. He has written extensively on management and is the Editor-in-Chief of the International Encyclopedia of Business and Management. He is also Co-Editor of the Asia Pacific Business Review and is on the editorial boards of many international journals.

Cherrie Jiuhua Zhu is Associate Professor and Director of the China Program in the Faculty of Business and Economics, Monash University. She has published papers in the areas of human resource management and international management. Her current research interests are globalization, marketization, social protection reform and their impact on management in China. 



\section{China's Business Reforms}

Institutional challenges in a globalized economy

\section{Edited by}

Russell Smyth, On Kit Tam, Malcolm Warner and Cherrie Jiuhua Zhu

Routledge
(2)
Toylor \& Francis Group
LONDON AND NEW YORK 
First published 2005

by RoutledgeCurzon

Published 2017 by Routledge

2 Park Square, Milton Park, Abingdon, Oxon OX14 4RN

711 Third Avenue, New York, NY 10017, USA

Routledge is an imprint of the Taylor \& Francis Group, an informa business

Copyright (c) 2005 Editorial matter and selection, Russell Smyth, On Kit Tam, Malcolm Warner and Cherrie Jiuhua Zhu; individual chapters,

the contributors

The Open Access version of this book, available at

www.tandfebooks.com, has been made available under a Creative

Commons Attribution-Non Commercial-No Derivatives 4.0 license.

British Library Cataloguing in Publication Data

A catalogue record for this book is available from the British Library

Library of Congress Cataloging in Publication Data

A catalog record for this book has been requested

ISBN 978-0-415-34517-0 (hbk) 


\section{Contents}

List of figures vii

List of tables $\quad$ ix

List of contributors xiii

1 Institutional challenges for China's business reforms 1 in a globalised economy

RUSSELL SMYTH, ON KIT TAM, MALCOLM WARNER AND CHERRIE JIUHUA ZHU

SECTION ONE

2 Industrial restructuring and corporate governance in China's large-scale state-owned enterprises

DIC LO AND RUSSELL SMYTH

3 Regional comparative analysis of China's banking system

KYM BROWN AND MICHAEL SKULLY

4 Solving agency problems in a cross-border environment: Ten 46 years of Chinese company listings in Hong Kong

ALICE DE JONGE

5 Foreign banks - market entry and foreign investment

ON KIT TAM

6 Accounting for intangible assets and the relevance of financial statements in developed and emerging capital markets: Australia and China

JAYNE M. GODFREY AND WEI LU 
vi Contents

\section{SECTION TWO}

7 Changing structure of Chinese enterprises and human resource management practices in China

SHUMING ZHAO

8 The management of human resources in Shanghai A case study of policy responses to employment and unemployment in the People's Republic of China

GRACE O. M. LEE AND MALCOLM WARNER

\section{SECTION THREE}

9 Employee perceptions of social protection reform in Shanghai: diversity across ownership forms and occupations

CHERRIE JIUHUA ZHU, CHRIS NYLAND AND BRIAN COOPER

10 Pension reform in China: imperatives, constraints and outcomes

PETER SAUNDERS AND SUN LUJUN

11 Globalization and occupational health and safety regulation in China

CHRIS NYLAND, RUSSELL SMYTH AND CHERRIE JIUHUA ZHU

\section{SECTION FOUR}

12 China's entry to the WTO

Effects of reducing tariff and non-tariff barriers and endogenous productivity growth

YINHUA MAI

13 Raw entrepreneurship and the rise of the new private sector in western China The Hope Group of Chengdu, Sichuan province MARIKA VICZIANY AND GUIBIN ZHANG 


\section{Figures}

3.1 Growth of domestic credit and GDP in China 32

3.2 Domestic and international bank financing 33

3.3 World Economic Forum: financial market indicators for China 41

3.4 World Economic Forum: soundness of banks 42

$\begin{array}{ll}\text { 7.1 China economic growth after } 1978 \text { reform } & 107\end{array}$

7.2 A comparison of different forms of corporations in China 112

8.1 Chinese labour market model 130

8.2 GDP growth of China and Shanghai, 1980-2001 135

8.3 Re-employment of laid-off workers in China and 135

Shanghai, 1998-2000

12.1 Tariff reductions and endogenous productivity growth 201 



\section{Tables}

2.1 Value-added of China's industrial enterprises, 1978-2001 14

2.2 Liability-to-asset ratio and loss-to-output ratio, 1995, 15 1998,2000

2.3 Relative per enterprise value-added, 1985-2001 17

3.1 Financing patterns 30

3.2 Macroeconomic variables (all expressed as percentages) 32

3.3 Bank financing across Asia (\% of GDP) 33

3.4 Banking sector, international banking: loans to deposits ratio 34 (all expressed as percentages)

3.5 Commercial bank descriptive statistics (2001) 35

3.6 Banking sector risk and non-performing loans 36

$\begin{array}{ll}3.7 & \text { Banking powers across countries } \\ 37 & 37\end{array}$

3.8 Commercial banks' securities and equities (billions of US dollars) 38

$\begin{array}{ll}3.9 \text { Bank supervision } & 39\end{array}$

3.10 Government ownership of top 10 banks $\quad 40$

3.11 Niche business activities of foreign banks in Asia 41

3.12 Internet banking in Asia $\quad 42$

5.1 CAMEL analysis of bank strength 68

5.2 China's WTO commitment to the opening of its banking system, 73 2002

5.3 Regulation of foreign banks in China - basic elements 74

5.4 Conditions for foreign banks to add a new branch 77

5.5 Selected requirements for Chinese shareholding banks to open $\quad 77$ new branches

5.6 Chinese shareholding banks total assets (end of 2000) 78

6.1 Summary of current requirements for accounting for intangibles 84 in Australia and China

6.2 Sample selection 93

6.3 Industry distributions $\quad 94$

6.4 Descriptive statistics $\quad 98$

6.5 Regression of market value of equity on capitalized intangible $\quad 100$ assets and other balance sheet items 
6.6 Incremental explanatory power of capitalized intangible assets 103 to models of the market value of equity

7.1 Characteristics of personnel management before $1978 \quad 108$

7.2 The development of the personnel system in China since the 109 early 1980 s

7.3 Number of corporations and ownership structure of enterprises $\quad 110$ in China (December 31, 1996)

7.4 Number of corporations, ownership structure, number of employees and percentage of employees of each type in firm (December 31, 2001)

7.5 Survey results of salary for key positions in foreign-invested firms in Guangzhou (2002-2003, RMB)

7.6 Compensation for top management in top 20 Chinese listed firms 118 2003

7.7 Compensation for the top 20 independent directors of Chinese listed companies

7.8 Stock options for the top 20 chairmen of the board in Chinese listed firms 2003

7.9 Stock options for the top 20 general managers in Chinese listed firms 2003

8.1 Institutional changes in the Chinese labour market

9.1 The ranking of 'hotspot' social topics among urban citizens (multiple choice)

9.2 Hotspot social topics most concerned among different social strata in cities in $2002(\%$, multiple choice)

9.3 Profile of survey respondents

9.4 Social protection measures by ownership

9.5 Social protection measures by occupation

9.6 Multiple regression analysis of independent variables on satisfaction with social protection policies

10.1 Living arrangements among the urban aged in China in 164 2000 (percentages)

10.2 Urban aged: mean incomes by age and gender in 1992 and 166 2000 (RMB per month and percentage)

10.3 Urban aged: mean expenditures on basic necessities by age and gender in 1992 and 2000 (RMB per month and percentage)

10.4 Changes in subjective well-being among the urban and rural aged, 1992 to 2000

10.5 Preferred forms of preparation for old age for young people, 2000 (percentages)

10.6 Percentage who think that their children are filial, 1992 and 2000

10.7 The incidence and amount of children's financial support for aged parents in urban and rural areas, 1992 and 2000 (percentages) 
11.1 Work-related fatalities and injuries in China $\quad 182$

$\begin{array}{ll}\text { 11.2 Fatalities in coal mines } & 183\end{array}$

12.1 Baseline: history and forecasts of average annual growth 200 2000-2006

12.2 Macro effects of reducing tariff and non-tariff barriers; 202 percentage deviation from baseline by 2006

12.3 Effects of reducing tariff and non-tariff barriers: sectoral output; percentage deviation from baseline by 2006

12.4 Effects of reducing tariff and non-tariff barriers: exports and imports by commodity; percentage deviation from baseline by 2006

12.5 Effects of reducing tariff and non-tariff barriers: gross output by region; percentage deviation from baseline by 2006

A.1 Reductions in tariffs and tariff equivalents of non-tariff barriers and endogenous productivity improvements; percentage change between 2002-2006

13.1 Breakdown of private enterprises by sectors in 2002 (percentages)

13.2 Geographical distribution of private firms (2001)

13.3 The economic cost of material and energy in the production of Hope pig feed 



\section{Contributors}

Kym Brown is from the Department of Accounting and Finance, Monash University.

Brian Cooper is from the Department of Management, Monash University.

Alice de Jonge is from the Department of Business Law and Taxation, Monash University.

Jayne M. Godfrey is from the Department of Accounting and Finance, Monash University.

Grace O. M. Lee is from City University of Hong Kong.

Dic Lo is from the Department of Economics, School of Oriental and African Studies, University of London.

Wei Lu is from the Department of Accounting and Finance, Monash University.

Lujun Sun is from the China Research Centre on Ageing, Beijing.

Yinhua Mai is from the Centre of Policy Studies, Monash University.

Chris Nyland is from the Department of Management, Monash University.

Peter Saunders is from the Social Policy Research Centre, University of New South Wales.

Michael Skully is from the Department of Accounting and Finance, Monash University.

Russell Smyth is from the Department of Economics, Monash University.

On Kit Tam is from the Faculty of Business and Economics, Monash University.

Marika Vicziany is from the Monash Asia Institute.

Malcolm Warner is from Judge Institute of Management, University of Cambridge.

Guibin Zhang is from the Monash Asia Institute. 


\section{xiv Contributors}

Shuming Zhao is from the School of Business, Nanjing University and School of Graduate Studies, Macau University of Science and Technology.

Cherrie Jiuhua Zhu is from the Department of Management, Monash University. 


\title{
1 Institutional challenges for China's business reforms in a globalized economy
}

\author{
Russell Smyth, On Kit Tam, Malcolm Warner and \\ Cherrie Jiuhua Zhu
}

\subsection{Introduction}

The reform of China's economy and business environment and the opening up to the outside world over the last 25 years have occurred against a backdrop of increasing globalization and integration into the world economy. Indeed, we will argue that it is likely that the latter changes have been the driving force behind the former. Most observers of China's reforms are united in the view that these have been successful in terms of promoting economic growth and improving the living standards of the masses, often with reservations vis-a-vis the increasing inequality of income and wealth. Few would question that the average Chinese is better off today than when the market reforms commenced in the late 1970s. 'Winners', on the whole, are likely to outnumber 'losers'.

However, China has clearly encountered problems and challenges in the building of new institutions required for the economy and society to function and thrive in the complex processes of marketization and globalization. Foremost among these from the perspective of business is the restructuring of Chinese state-owned enterprises (SOEs), reform of the financial and banking system and concomitant reforms to labour markets and social welfare provision, albeit with 'Chinese characteristics'. China has now moved to a more efficient system of resource allocation. The link between economic restructuring and globalization was most recently brought into sharp focus following China's accession to the World Trade Organisation (WTO), with China's enterprises confronted with increasing levels of competition from foreign sources.

The essays in this edited volume collectively provide an overview of how China's economic reforms have evolved and how policy-makers and market participants are responding to the challenges of increased global competition. Many of them provide a fair degree of detailed analysis about how this has come to pass. Section One of the book, which consists of the next five chapters, examines corporate governance reform in SOEs and listed companies and the development and restructuring of China's financial sector. It is fair to say that these are the two major institutional reforms that have occupied the business policy agenda in China over the last decade. Section Two of the book contains chapters on the evolution of human resource management (HRM) and labour market reform. One of the accompanying features of the increasing 


\section{Russell Smyth, On Kit Tam, Malcolm Warner and Cherrie Jiuhua Zhu}

marketization of SOEs and corporate governance reform in listed companies has been the evolution of HRM in China and the growing pressures of unemployment as SOEs change their work practices. The chapters in Section Two review these developments.

Section Three of the volume focuses on the changing nature of social welfare provision. There is increasing recognition among many scholars that globalization is more than likely a 'double-edged sword' (see Guan 2001a, Kapstein 2000, Milanovic 2003). While the globalization process has contributed to rising incomes in developing countries such as China through increased trade and investment flows, it has also made the need to create a sophisticated social protection regime to protect those who are made vulnerable from increased competition more pressing. These include the elderly, the unemployed and those in poor health. The chapters in Section Three examine how China has responded to the need to develop a social protection regime to protect the 'losers' from the globalization process and, at the same time, make the marketization process sustainable into the future. The final section of the book contains two chapters assessing the impact of China's accession to the WTO on the economy and the emergence of the private sector and new breed of entrepreneur in China. We conclude the book with these two chapters since both examine topics that look to the future of Chinese business. How China adapts to being a member of the WTO will be probably the most important issue for business in China in coming years. The emerging importance of private enterprises has been one of the major developments in China's business reforms in recent times and it is likely that private enterprise will play an even greater role in the future as the state-owned sector shrinks further. In the remainder of this chapter, we provide an overview of the institutional challenges facing China's reforms and examine the contents of the chapters that make up the balance of this volume in greater detail.

\subsection{Section one: corporate governance and financial reform}

Effective corporate governance, most authorities in the field agree, helps protect and enhance the interests of stakeholders in a company, particularly shareholders. Corporate governance now occupies the centre stage of enterprise reform in China (Tenev et al. 2002). The Fourth Plenum of the Chinese Communist Party's Fifteenth Central Council, held in September 1999, identified corporate governance as 'the core' of the modern enterprise system. The main tenet of China's approach to corporate governance development is the adoption of key features from the Anglo-American model of corporate governance, which requires the existence of certain institutional conditions including a well functioning financial and regulatory system for it to operate effectively (Tam 1999). The 1997 Asian financial crisis and the problematic mass privatization in Russia have highlighted the importance of having effective corporate governance arrangements in emerging and transitional economies (Frydman et al. 1996, Estrin and Rosevear 1999, Claessens et al. 2000). For a developing 'transitional economy' such as China, in which the government 
retains considerable influence, even if the apparatus of the old command economy has been virtually dismantled, the role of corporate governance is now widely accepted by scholars and policy-makers to be critical to the country's enterprise and financial reform and to the development of a globally competitive economy (Chen 2003, Clarke 2003, Walter and Howie 2003). Globalization and corporate governance issues are now more intertwined than ever before, problems of corruption notwithstanding. With fast expanding international trade and inward foreign direct investment, the need to develop effective corporate governance and an efficient financial and banking system has taken on added significance.

Chapter 2 by Dic Lo and Russell Smyth, Chapter 4 by Alice de Jonge and Chapter 6 by Jayne Godfrey and Wei Lu examine different aspects of corporate governance development in Chinese enterprises. In Chapter 2, Lo and Smyth provide an overview of reform of SOEs, focusing on the contribution of large SOEs and enterprise groups. There is a spirited debate in the literature on the role of large SOEs. Some authors see large SOEs as inefficient 'dinosaurs' dragging down the state-owned sector (see for example McNally and Lee 1998, Shieh 1999). Others, more controversially, argue that large SOEs have played a vital role in China's economic success through supplying producer goods and establishing substantial linkages which have fuelled growth in downstream industries (Nolan 1996, Nolan and Zhang 2002). Lo and Smyth, whose sympathies lie with the second camp, focus on the positive contribution of large SOEs at a time when the role of the state sector has been shrinking. To explain how the share of large SOEs has held up over time, they offer a 'non-orthodox' account of industrial restructuring and changing corporate governance, focusing on the match (or mismatch) between the institutions and external demand conditions.

In Chapter 4, de Jonge examines the emerging corporate governance structures of listed companies, focusing on the internal structure of Chineseincorporated companies listed on the Hong Kong Stock Exchange (H-share enterprises). This démarche is particularly timely in a period when high profile accounting and corporate governance scandals in the United States have emphasized to the business community the need for improved corporate governance standards in securities markets throughout the world. De Jonge examines the way in which recent developments and reforms in laws and regulations governing $\mathrm{H}$-share enterprises have started to alter the composition of boards and the relationship between shareholders and management. The chapter demonstrates both how things are changing for the better and the many deficiencies that still need to be addressed.

Another aspect of corporate governance reform, which was highlighted by the US-based Enron and WorldCom collapses and other non-US 'basket-cases' such as the Italian conglomerate Parmalat, has been the need to develop sound financial reporting practices. Godfrey and Lu positively address this issue in Chapter 6. Existing research points to differences in the manner in which investors in developed countries value the intangible assets reported in firms' financial statements. There is no research, however, into the association between the market value of firms in developing countries and their book values 


\section{Russell Smyth, On Kit Tam, Malcolm Warner and Cherrie Jiuhua Zhu}

of intangible assets. Since the promulgation of China's first 'Western-style' accounting standard in 1992, accounting standards and regulations issued by the Chinese government have become increasingly internationally compatible. This move opened up opportunities to examine the economic relevance of accounting in the emerging economy of China. Using a large sample of Australian and Chinese companies, Godfrey and $\mathrm{Lu}$ investigate the value relevance of capitalized intangible assets, both in aggregate and as individual capitalized items. One of their main findings is that in China, the book value of intangible assets is a very small proportion of the book value of total assets and none of the capitalized, intangible asset book values are significantly associated with the market value of equity. They cogently discuss the implications of this for financial reporting reform.

The 1990s saw the establishment of new nationwide shareholding banks, significant expansion of the insurance sector, development of a domestic capital market and the emergence of consumer and housing finance. The financial sector and particularly the securities market, however, still face many challenges that are inextricably tied up with corporate governance reform and in particular reform of the SOEs. These state firms receive the bulk of funds allocated through the formal credit system and non-commercial considerations, such as the need to sustain loss-making SOEs, continue to influence bank lending (see OECD 2002 for an overview). In 1999 the Chinese government announced an equity-for-debt swap (EDS) scheme to restructure the SOEs and clear up the bad loans of the state-owned banks. As Kym Brown and Michael Skully discuss in Chapter 3, official figures reported before the asset management companies took over bad loans were that non-performing loans were in the 25-30 per cent range, but in practice the actual percentage of non-performing loans was much higher. The limited empirical evidence which is available suggests that to this point the EDS has had limited success in restructuring SOEs or improving the bad loan situation of the banks. The problem is that in the end the EDS is only a financial scheme, an accounting solution to the problem of bad debts, while SOE reform is a real socio-economic problem that is subject to serious socio-economic and political constraints (see Smyth et al. 2004).

Different aspects of the relationship between enterprise reform, foreign investment and banking reform in China are emphasized in Chapter 3, by Brown and Skully, and Chapter 5 by On Kit Tam. Brown and Skully compare China's financial system with others in the Asia-Pacific region, emphasizing the banking system and its reform progress. The international perspective is interesting given China's emerging financial importance in East Asia. As a proportion of GDP, China has the largest domestic banking system in East Asia and, when combined with international borrowings, it is third behind Hong Kong and Singapore. Brown and Skully make several recommendations for further reform to China's financial sector, including: the full publication of financial statistics; the continued workout of non-performing loans; more bank supervisors; the development of other financing options for investors; and the removal of unprofitable SOE funding to policy banks.

In Chapter 5, Tam analyses the main issues influencing the entry of foreign banks into China's banking sector, with particular reference to the government's 
aim to promote economic development in the western region. It is generally recognized that the Chinese banking sector has lagged behind other sectors in the reform process. As demonstrated by the beneficial impacts from the entry of foreign insurance companies in China during the last decade, Tam argues that an increase in the level of market competition in China's banking sector from foreign banks will help the reform of this important economic sector while at the same time enhancing the country's foreign investment environment, particularly in the western region. One of the implications of China's integration into the global economy has been increasing regional disparities between the coastal provinces that attract the bulk of foreign investment and the lower-income central and western provinces. In response to these income divergences, through the ninth Five-Year Plan (1996-2000) and the State Council's special administrative office, the Leading Group for Western Development, development of western China is now seen as a priority. Multilateral lending agencies are also targeting funds towards the development of western China. Tam argues that more rapid liberalization of market entry for foreign banks will assist in the economic development of China's western region. He discusses how the entry of foreign banks into the region can have a positive effect on the flow of foreign direct investment into the region, thereby reducing the big regional income disparities.

\subsection{Section two: human resources and labour market reform}

China's labour force has experienced a profound transformation since the late 1970s, which has been a direct as well as an indirect result of enterprise restructuring to improve global competitiveness vis-a-vis the wider forces of globalization (see Warner 1995). In 1978, most of the labour force was employed in rural communes or in urban SOEs; by the end of the 1990s, one third of the rural labour force was engaged in non-agricultural activities and about three-fifths of the urban labour force was employed outside the state sector, in urban collectives, joint ventures and private enterprises (Fleisher and Yang 2003). Prior to 1978, HRM in China was characterized by the 'three irons' policy consisting of the 'Iron armchair' (tie jiaoyi), 'Iron rice-bowl' (tie fanwan) and 'Iron pay' (tie gongzi). Labour arrangements under central planning were characterized by labour allocation by labour bureaus, the hukou (residence registration system), and strict control of the dang'an (personal file) by the danwei (work unit or employing organization; see Meng 2000).

However, as Shuming Zhao discusses in Chapter 7, since the commencement of market reforms, HRM has undergone somewhat of a revolution. The labour contract system, earlier pioneered in Shenzhen, was first introduced nationally by way of a Labour Regulation in 1986 to cover new entrants into state and collective enterprises. In 1987, regulations calling for an extension of fixedterm contracts to incumbent workers were introduced. This step provided enterprises with some autonomy to make hiring decisions for the first time, and increased the risk of being laid off for employees who did not meet their employment obligations (Fleisher and Yang 2003), although these same 


\section{Russell Smyth, On Kit Tam, Malcolm Warner and Cherrie Jiuhua Zhu}

regulations left a large residual role for planners to meet regional employment targets (Meng and Kidd 1997). A managerial responsibility system has also been introduced to link managerial performance and compensation (Groves et al. 1995), and by the second half of the 1990s some managers in SOEs were being employed on three-year contracts, which could be terminated for failure to meet performance criteria (Morris et al. 2001: 711). As Zhao considers in more depth in Chapter 7, there have been related reforms to the hukou and dang'an systems to make labour markets more flexible.

Since the late 1990s, unemployment has become a major problem in China, with huge numbers of workers being laid off from SOEs. The xiagang (lay-off) reforms were first experimented with in 1994 and were officially launched in 1997 with the intention of resolving the problem of inefficiency in the state sector by furloughing a quarter of its workers within four years (1997-2001) (Appleton et al. 2002). Between 1998 and 2002 there were 26 million workers laid off from SOEs (Armitage 2003, Solinger 2003). This large-scale shedding of labour has become a major socio-economic problem given that studies have found that those workers who have borne the brunt of the redundancies are the least able to find alternative work. This situation has the potential to create a 'lumpenproletariat' with feelings of betrayal (Morris et al. 2001). For example, using household survey data for 1999/2000, Appleton et al. (2002) found that the risk of retrenchment was highest for the most vulnerable in society - namely women, the less educated, the low-skilled and the middle-aged, and that the duration of unemployment was longest for those in poor health, the less educated and women with children. The problem of redundancies has been exacerbated by China's integration into the global economy, as the state-owned sector has been confronted with increasing levels of competition from the time of China's accession to the WTO. Over the last two decades the 'Gini coefficient', measuring income inequality, has gone up from around 0.20 in the Maoist days to over 0.45 in the post-Deng era, more in line with other Asian economies.

In Chapter 8, Grace Lee and Malcolm Warner argue that unemployment, hand in hand with poverty, now poses a serious threat to both social stability and the rule of the Chinese Communist Party, and that this demands an urgent human resources policy response. This concern is reflected in widespread documentation of worker unrest, with labour protest an everyday event in China's cities (Morris et al. 2001, Solinger 2003). In their chapter Lee and Warner first examine the issues of employment and unemployment in China, explaining that the low official rate of joblessness of around 4 per cent, is in reality double that figure (possibly, indeed, even more), then move on to explain the institutional changes that brought the problem about, using Shanghai as a case study to explore the policy responses. However, although they find that the labour programme in Shanghai may have been relatively successful at first, they conclude by arguing that this does not necessarily mean that it would also succeed if implemented nationwide; its success in Shanghai, they suggest, is due primarily to the particularly rapid growth of the local economy there. 


\subsection{Section three: social welfare reform}

Prior to the introduction of market reforms, China's social security system was predominantly a danwei-based (work-unit-based), defined-benefit, 'pay-as-yougo' type, primarily restricted to the public sector and confined to urban areas. For those who qualified, coverage was comprehensive. This policy included: old age care; health care; insurance for injury, disability or death irrespective of whether they were work-related; maternity benefits; and funeral subsidies (see Dong and Ye 2003 for an overview). However, by the mid-1980s it was clear that social security was lagging behind economic reform. The main problem was that that the danwei-based welfare system undermined the competitiveness of SOEs because it imposed a significant financial burden on the enterprise. The strategy now is to offload more of the welfare costs, either onto the individual or the community, or both.

In response to the increasing financial pressure on SOEs, commencing with the 'Decision of the Chinese Communist Party Central Committee on the Reform of the Economic System' in October 1984, the state has adopted a series of social welfare reforms nationally. A critical feature of the 'Decision' was the requirement that enterprises practise independent accounting and assume responsibilities for their own profits and losses, therefore breaking the traditional tie between government and work-based social security (Dong and Ye 2003). Subsequent reforms have centred on the implementation of a number of social insurance programmes designed to cover the major risks confronting individuals working in both public and private sectors in a market economy (Saunders and Shang 2001, Zhu 2002, Whiteford 2003). The new social insurance regime is financed by individuals, enterprises and government. It has two major objectives (Nyland et al. 2004). One is to relieve enterprises in the public sector of the full responsibility for welfare provision and ensure that the burden is shouldered fairly between the major stakeholders. The other is to have the same social security system established in the private sector to protect employees and to curtail the prevalence of free-riding.

Currently, all firms are required to pay a prescribed amount of social insurance. The national regulations mandate that employers must contribute 20 per cent of the wage bill for pension insurance, although in practice the amount varies between provinces from 15 per cent to 30 per cent. Employers are also required to contribute 6 per cent of payroll for health insurance (although this varies in different areas; in Shanghai, for example, it is 12 per cent), 2 per cent of payroll for unemployment insurance and 1 per cent of payroll each for industrial injury and maternity insurance (Whiteford 2003). Employees contribute 5 per cent of payroll for pension insurance, 2 per cent of payroll for health insurance and 1 per cent of payroll for unemployment insurance (Zhu 2002).

In Chapter 9 Cherrie Zhu, Chris Nyland and Brian Cooper extend existing perception research for China by examining the diversity of employees' views on social protection reform that prevail across firms with differing ownership forms and occupations. This is an interesting exercise because, as they point out, existing research on perceptions of social welfare coverage in China has tended 


\section{Russell Smyth, On Kit Tam, Malcolm Warner and Cherrie Jiuhua Zhu}

to concentrate on views among workers in SOEs at a time when the Chinese government is committed to policies that are reducing the number and relative significance of SOEs while extending coverage in other ownership forms. Therefore, extant studies that focus on perceptions in SOEs are likely to tell only part of the story. The chapter suggests that ownership form has a significant impact on employee perception of social protection reform, with employees in private enterprises having a more positive attitude towards personal risk management, labour mobility and the role of trade unions, and a greater sense of security and satisfaction with social insurance policies than employees in either foreign-invested firms or SOEs.

One notable demographic problem in China is the rapid increase in the dependency ratio in recent times. In 1978, China's old-age dependency ratio (number of pensioners to number of active contributors) was 1:30. This figure changed to 1:5.4 in 1989 and 1:3.5 in 2001 and is projected to be 1:1.69 in 2050 (Zhu 2002: 42). Peter Saunders and Lujun Sun tackle this issue through examining pension reform in the context of a broader study of income support for the aged in Chapter 10. In contrast to most recent studies of pension reform in China, Saunders and Sun emphasize the importance of looking beyond pensions (and by implication, beyond pension reform) in understanding the factors that contribute to wellbeing in old age and the opportunities to influence it. Specifically, the chapter reports some results from a project that is examining the living standards of the aged in China in 2000 and how these have changed in the time since 1992, a period characterized by rapid and expensive reform of policies affecting the aged. Saunders and Sun investigate what effect these policies have had on the economic status of older people, the role played by the family and how attitudes have changed towards these issues. Saunders and Sun consider the role of pensions in providing income support for the aged, how this has changed, and its consequences for support provided by family.

Over the last decade China has emerged as the 'world's factory floor', and occupational health and safety (OHS) laws, regulations and implementing agencies are struggling to keep up with China's rapid economic growth (Brown and O'Rourke 2003: 299). In Chapter 11 Chris Nyland, Russell Smyth and Cherrie Zhu examine the interplay between fast rates of economic growth, globalization and recent developments with OHS and industrial injury insurance legislation. Nyland, Smyth and Zhu argue that marketization and globalization have had a dual effect on OHS. On the one hand, providing an effective social protection mechanism is a precondition for further marketization and opening up to the outside world. On the other hand, providing the institutional mechanisms to protect workers' occupational health and safety is an integral part of protecting workers from the vicissitudes of globalization. Based on interviews with key stakeholders in Beijing, the chapter examines how China has managed this tension and discusses the extent to which the institutional and legal framework that it has put in place is effective in protecting workers' health and safety in the face of increasing levels of global competition. 
Institutional challenges for China's business reforms in a globalized economy 9

\subsection{Section four: implications of China's accession to the WTO and the rapid growth of the private sector}

The Chinese government has consistently argued that its decision to join the WTO is a 'win-win' deal for both sides (see for example People's Daily 18 January 2000, Economic Daily 21 January 2000). Others are more sceptical. For instance, Nolan (2002) expresses grave doubts about the ability of China's large firms to compete on a global level playing field. Warner $(2002,2003 a)$ and Lee and Warner in this volume emphasize that China's entry into the WTO, by speeding up the structural adjustment of industries, will put serious strain on the management of human resources and will increase employment pressures in the coming years as globalization increases. For this reason, as in any major economic restructuring process, China's entry into the WTO is unlikely to be 'Pareto-improving' (in the sense that some are made better off, while no-one is made worse off). Instead, there are bound to be both 'winners' and 'losers' from the process, as suggested earlier.

The real issue, therefore, is whether or not the potential gains outweigh the losses. Interest in estimating the potential effects of China joining the WTO on both the Chinese and world economies has led to a substantial and still growing computable general equilibrium (CGE) literature. The benefits from reductions in tariff and non-tariff barriers as estimated in the existing CGE literature are generally low, in the range 0.08 to 2.20 per cent of real GDP (see Gilbert and Wahl 2002 for an overview of existing studies). Yinhua Mai contributes to this literature in her examination of the effect of tariff and non-tariff barrier reductions in China in a CGE framework in Chapter 12. In contrast to the existing CGE literature, Mai takes account of the effect of endogenous productivity growth, which has been considered to be one possible reason for previous low estimates. She concludes that China's gain in real GDP from the tariff reductions is much higher with the endogenous productivity growth than without it. With endogenous productivity growth, China's real GDP is likely to be 2 per cent higher than the baseline by 2006, while without endogenous productivity growth China's real GDP is likely to be 1 per cent higher than the baseline by 2006. Mai also draws some interesting conclusions about the regional effects of China joining the WTO, with the coastal cities/provinces such as Tianjin, Shanghai, Jiangsu, Zhejiang, Guangdong, and Fujian (which have high levels of export-oriented light manufacturing industries) expected to benefit most from tariff reductions.

The private sector in China has experienced spectacular growth over the last few years (see Krug 2004). Between 1996 and 2001, private enterprises in China grew at an average annual rate of about 24 per cent. The final chapter, by Marika Vicziany and Guibin Zhang, contains a case study of the Hope Group, which is a particularly interesting example of private entrepreneurship because it has its origins in western China where the private sector is far smaller and less dynamic than in the more prosperous (and more often studied) coastal provinces. One of the reasons for this, as Tam discusses in Chapter 5 and elsewhere (Tam 2004), is the lack of access to capital. In spite of this obstacle the Hope Group has emerged as one of the most successful private companies in China and, 
according to Forbes magazine, the Liu brothers who founded it are the richest men in China today.

\subsection{Conclusion}

We can conclude from the above discussion that the quest for economic growth and modernization through marketization and globalization has set the scene for a wide range of structural and infrastructural changes in the Chinese economy. The transformation of the economic system and the growing involvement of China in the international economy since the Open Door policy was launched in 1978 has resulted in the abandonment of structures of the old command economy and the building of new institutions created either from the grass roots or in a top-down fashion, reflecting China's gradual and experimental approach to reform and development. China today is dramatically different from what it was when the Open Door policy began, let alone in Mao's times. The contributions to this volume exemplify this theme in their respective ways but all reveal the breadth as well as the depth of change that has taken place. They have shown that on the whole China has dealt with the challenges in pragmatic and effective ways in creating a more vibrant and functioning business environment that contains sectors capable of competing in the global market, although there are clearly areas that require more fundamental changes.

In many ways and for a variety of reasons, the Chinese government has tried to keep its changes ostensibly 'Chinese' (see Warner 2003a). Similarly to the development experience of other countries, it is clear that adaptation to the wider processes of globalization may often have a distinctly 'national' flavour. The transition to a market economy and a competitive society may well be mitigated by China's historical and cultural incubus. However, a determination to keep control of the extension of market forces that may ultimately undermine the domination of the Party and state apparatus has also played a critical role in shaping the country's economic and societal transformation in recent years.

The last decade has nonetheless seen an even bolder foray into the world economy and greater political institutionalization, as well as further steps to 'civility' and 'legality' (Dittmer 2003), all of which suggest that outgoing President Jiang Zemin's political legacy, intertwined with ex-Premier Zhu Rongji's pragmatic economic steering, was in fact more important than most observers would initially have expected. The next 'Fourth' generation of leadership has a tricky balancing act to perform. Already President Hu Jintao and Premier Wen Jiabao have, since their elevation to high office in late 2002, indicated their willingness to carry the torch of reform one pace further, but at the same time shown their compassion towards the 'poor' and the 'laid off'. The message is clearly that 'winners' must support 'losers', if political stability and social cohesion in contemporary China are to be maintained. 


\section{SECTION ONE}





\title{
2 Industrial restructuring and corporate governance in China's large-scale state-owned enterprises
}

\author{
Dic Lo and Russell Smyth
}

\subsection{Introduction}

China's record of economic development in the last two decades of the twentieth century was spectacular by international comparison. Whilst most parts of the non-Western world were experiencing sluggish economic growth or outright stagnation, China's per capita income on average increased by 9 per cent a year over a period of more than twenty years. This record, in particular, stands in contrast to the economic depression in countries of the former Soviet bloc which also underwent similar processes of systemic transformation. However, while China's development record is generally admired, the explanation for its achievement has been a matter of debate among observers. A prominent assertion, mostly in journalistic writings but also in the scholarly literature, has been that China's success has occurred in spite, rather than because, of its theoretically dubious approach to systemic transformation. Indeed, orthodox economists tend to argue that. by avoiding or delaying mass privatization and rapid liberalization in certain key sectors (such as finance), China's systemic transformation is likely to have contributed, on balance, negatively to economic development. The outstanding record of actual development, therefore, has rested on factors other than those attributable to the reformed economic system. Understandably, this assertion has been confronted with counter-arguments by scholarly studies from heterodox orientations.

At the heart of the debate is the division of opinion in assessing the reform and development of China's state-owned enterprises (SOEs). Given the predominance of SOEs in the economy (particularly in industry) throughout most years of the reform era, the division thus amounts to a fundamental divide over the success or failure of the systemic transformation in toto. The process of industrial restructuring, and with it the evolution of corporate governance, has also been viewed in this light. Orthodox economists and lending agencies offer a three-part argument. First, large-scale SOEs are 'dinosaurs' which represent a drag on the state-owned sector and illustrate the dangers of the relationship between government and enterprise being too close, which was the root cause of the Asian financial crisis (McNally and Lee 1998, Shieh 1999). McNally and Lee (1998: 46) reflect the orthodox view on promoting large SOEs: 


\section{Dic Lo and Russell Smyth}

The Achilles heel of [developing large enterprise groups] is that this policy can easily lead to the formation of large, unmanageable and monopolistic corporate empires that are closely tied to the state. It is exactly this type of 'incestuous' government-enterprise relations that are held responsible for the Asian financial crisis.

Second, the gross inefficiency of the corporate governance of SOEs is responsible for all, or most, of the alleged problems in the Chinese economy, such as unsustainable public debts, ballooning non-performing loans of state banks and the distortions that exacerbate mass unemployment. Third, the proliferation of small enterprises and the thriving non-state sector is responsible for China's growth (Sachs and Woo 1994, World Bank 1997a, OECD 2002).

The first claim in particular has been disputed by non-orthodox scholars on empirical and conceptual grounds. There is an emerging literature which argues that large-scale SOEs have been crucial to explaining China's growth (Nolan 1996, 2001; Nolan and Yeung 2001a, 2001b; Nolan and Wang 1999; Nolan and Zhang 2002; Lo 1997, 1999b; Smyth 1997, 2000b). Nolan (1996) argues that there has been rapid growth in upstream industries and that through supplying producer goods and establishing substantial linkages this has fuelled growth in downstream industries, which are usually depicted in market-oriented accounts of China's growth record as the engines of growth. Lo (1999a) shows that the share of industrial output of large and medium enterprises, most of which are SOEs, has increased over the reform period and that the financial performance of large and medium size enterprises has been as good as, or better than, smallscale industries. Holz (2002) goes further and questions the second and third orthodox claims. He argues that the performance gap between SOEs and nonSOEs can be explained by two factors: SOEs face higher circulation tax rates than non-SOEs and SOEs have higher capital intensity. Holz (2002) further suggests that the decline in SOE profitability over time reflects economic transition factors, that non-SOE profitability declined following a similar time pattern, and that non-SOEs are no better-suited to withstand downturns than SOEs.

This chapter offers a (re)interpretation of China's industrial restructuring and changing corporate governance, with a view to shedding new light on the debate over the performance of SOEs as well as on China's systemic transformation as a whole. The objectives are twofold. First, we base our interpretation of China's industrial performance on well-developed economic theories of institutions and development, particularly those derived from studies of East Asian industrialization. Second, we present, and attempt to interpret some empirical observations that are arguably of central importance to the understanding of the industrial restructuring and changing corporate governance. In particular, the chapter analyses the significance of the reform and development of China's large-scale industrial enterprises (LEs), which have been at the core of the state sector and of Chinese industry as a whole.

The chapter is organized as follows. The next section discusses the process of industrial restructuring and provides an initial assessment of its general significance. Section 2.3 turns to central issues associated with institutional 
evolution in large SOEs. By linking up these issues with the empirical observations on industrial restructuring in section 2.2, and through drawing on relevant theories of institutions and development, the section seeks to clarify the strength and weakness of China's reformed economic system. Section 2.4 summarizes the chapter's main arguments and findings and provides some speculative observations on the future prospects for China's ongoing economic transformation.

\subsection{Industrial restructuring: observations and (re)interpretation}

China's market-oriented systemic reform has coincided with the shrinking share of SOEs in the economy, particularly in industry. As can be seen from Table 2.1, between 1978 (the starting year of reform) and 2001, SOEs' share of valueadded in Chinese industry as a whole decreased massively, from 78 per cent to 34 per cent. There are three important points to note concerning this trend. First, the rate of decrease was much slower in the first half of the reform era than in the second half, with the value-added share still at a high level of 60 per cent in 1989. More than half of the decrease in the value-added share occurred in the few years from 1994 to 1997, which was due to a state-sponsored downsizing drive (the significance of which will be discussed in the next section). Second, throughout most years of the reform era, SOEs still registered positive growth in their value-added; the only years in which there was negative growth were 1994 and 1995. On average, the real growth rate per year from 1978 to 2001 was a respectable 7 per cent. It was the much faster rate of growth, of 11 per cent a year, for Chinese industry as a whole that has accounted for the decreasing value-added share for SOEs. Third, the much faster rate of growth in total industrial value-added has been largely due to the expansion of rural, informal industrial enterprises. These enterprises, however, are not in direct competition with SOEs. Regarding their position in the formal sector of Chinese industry, the value-added share of SOEs did decrease but at a much less dramatic pace, from 82 per cent in 1978 to 74 per cent in 1989 and further to 52 per cent in 2001.

Another important aspect of China's industrial growth record has been the good performance of LEs. Not only did these enterprises manage to retain their vital position in Chinese industry, but they actually increased their value-added share from 31 per cent in 1978 to 34 per cent in 2001. This occurred despite the take-off in rural industrialization and hence the massive expansion of informal, small-scale enterprises over this period. The average real growth rate per annum of the value-added of LEs was 0.4 percentage points above Chinese industry as a whole over this period of more than twenty years. But it is of note that most LEs are in fact SOEs. Before 1992, the year when the state began to implement its reform measure of transforming SOEs into various forms of shareholding corporations, virtually all LEs were SOEs. In 1993, SOEs accounted for 87 per cent of the value-added of LEs. The share subsequently decreased to 74 per cent by 1997, along with the expansion of shareholding firms in the country. In view 
14 Dic Lo and Russell Smyth

Table 2.1 Value-added of China's industrial enterprises, 1978-2001

\begin{tabular}{|c|c|c|c|c|c|c|c|c|}
\hline & \multicolumn{4}{|c|}{$\begin{array}{l}\text { Shares of value-added (at current } \\
\text { prices) in Chinese industry as a whole }\end{array}$} & \multicolumn{4}{|c|}{ Real growth rates (\%) } \\
\hline & Formal & SOEs & SOEs+ & LEs & Total & Formal & SOEs & LEs \\
\hline 1978 & $95 \%$ & $78 \%$ & & $31 \%$ & & & & \\
\hline 1979 & $94 \%$ & $79 \%$ & & $31 \%$ & 8.7 & 7.7 & 9.5 & 8.9 \\
\hline 1980 & $90 \%$ & $74 \%$ & & $37 \%$ & 12.7 & 7.7 & 5.7 & 32.8 \\
\hline 1981 & $89 \%$ & $73 \%$ & & $29 \%$ & 1.7 & 0.3 & 0.3 & -20.0 \\
\hline 1982 & $89 \%$ & $72 \%$ & & $29 \%$ & 5.8 & 5.7 & 4.4 & 7.4 \\
\hline 1983 & $91 \%$ & $71 \%$ & & $30 \%$ & 9.7 & 12.1 & 9.2 & 12.1 \\
\hline 1984 & $90 \%$ & $70 \%$ & & $35 \%$ & 14.9 & 14.2 & 12.7 & 34.2 \\
\hline 1985 & $89 \%$ & $67 \%$ & & $32 \%$ & 18.2 & 17.1 & 12.7 & 8.7 \\
\hline 1986 & $84 \%$ & $62 \%$ & & $30 \%$ & 9.6 & 3.6 & 1.8 & 3.0 \\
\hline 1987 & $82 \%$ & $61 \%$ & & $32 \%$ & 13.2 & 9.9 & 10.8 & 19.1 \\
\hline 1988 & $80 \%$ & $58 \%$ & & $30 \%$ & 15.3 & 12.9 & 10.8 & 10.0 \\
\hline 1989 & $81 \%$ & $59 \%$ & $60 \%$ & $32 \%$ & 5.1 & 6.7 & 5.8 & 11.2 \\
\hline 1990 & $80 \%$ & $57 \%$ & & $33 \%$ & 3.4 & 1.5 & 0.8 & 6.7 \\
\hline 1991 & $79 \%$ & $55 \%$ & & $33 \%$ & 14.4 & 12.7 & 9.3 & 14.7 \\
\hline 1992 & $75 \%$ & $50 \%$ & & $32 \%$ & 21.2 & 14.8 & 11.8 & 18.4 \\
\hline 1993 & $91 \%$ & $51 \%$ & & $35 \%$ & 20.1 & 46.3 & 22.5 & 29.8 \\
\hline 1994 & $76 \%$ & $41 \%$ & & $32 \%$ & 18.9 & -0.6 & -5.7 & 9.7 \\
\hline 1995 & $62 \%$ & $34 \%$ & & $30 \%$ & 14.0 & -6.2 & -6.1 & 5.3 \\
\hline 1996 & $62 \%$ & $30 \%$ & $36 \%$ & $27 \%$ & 12.5 & 11.6 & 0.6 & 1.4 \\
\hline 1997 & $61 \%$ & $28 \%$ & $34 \%$ & $27 \%$ & 11.3 & 9.9 & 5.0 & 11.2 \\
\hline 1998 & $58 \%$ & & $33 \%$ & $27 \%$ & 8.9 & 3.5 & 6.3 & 11.2 \\
\hline 1999 & $61 \%$ & & $35 \%$ & $30 \%$ & 8.5 & 14.7 & 13.1 & 18.2 \\
\hline 2000 & $65 \%$ & $18 \%$ & $35 \%$ & $32 \%$ & 9.8 & 16.2 & 12.0 & 18.5 \\
\hline 2001 & $67 \%$ & $15 \%$ & $35 \%$ & $34 \%$ & 8.9 & 11.3 & 6.1 & 14.7 \\
\hline
\end{tabular}

Sources: Zhongguo Gongye Jingji Tongji Nianjian (China Industrial Economics Statistical Yearbook), Zhongguo Tongji Nianjian (China Statistical Yearbook), and Zhongguo Tongji Zhaiyao (China Statistical Abstract), various years; and Renmin Ribao (People's Daily), 2 December 2002.

Notes

Total $=$ Chinese industry as a whole; Formal $=$ township-and-above independently accounting industrial enterprises before 1998, and all state-owned enterprises plus above-designated-size nonstate-owned enterprises from 1998; SOEs = state-owned enterprises; SOEs+ = state-owned enterprises plus state-controlled shareholding enterprises; LEs = large-scale industrial enterprises. Except for Total, all the value-added figures before 1992 are converted from net output data. The SOEs' real growth rates refer to those of SOEs+ from 1998.

of the fact that state-controlled shareholding firms typically account for around 6 per cent of total industrial value-added and that most of these firms are LEs, the value-added share in LEs of SOEs and state-controlled shareholding firms combined is likely to have remained at around 80 per cent even after 1997. 
The implication is that, because of the gradualist nature of China's market reform, SOEs did dominate Chinese industry in most years of the reform era, and that to a significant extent this position still remains. In this connection, the expansion of LEs is of particular importance. It should be noted that LEs in fact form the core of state industry, and that they have been the main carrier of the most important reform measures. Any appraisal of the efficiency attributes of the changing corporate governance in Chinese industry, indeed of the systemic reform as a whole, must take these observations into account.

However, before moving on to the discussion on corporate governance, it is useful also to look at LEs' relative performance in financial terms, in addition to that of output growth. Orthodox observers highlight that the weakness of China's economic transformation lies mainly in the financial sphere, often to the degree that it is argued that the weak financial performance of industrial enterprises has threatened the economy as a whole. Pessimists have even predicted that a financial crisis of the type that affected East Asia in 1997 is most likely to occur in China precisely because of this weakness. Whether or not these predictions are valid, again, in view of available evidence, it is clear that LEs have outperformed the rest of Chinese industry in this regard. Of immediate concern, in the efforts to avoid an 'East Asian-type' crisis, LEs have managed to reduce their liability-to-asset ratio from 61 per cent in 1995 to 57 per cent in 2000. This compares with the reduction from 66 per cent to 60 per cent for all SOEs, and from 65 per cent to 60 per cent for all formal industrial enterprises. Meanwhile, as can be seen from Table 2.2, LEs have performed much better than other firms in coping with the problem of loss-making. For large and medium enterprises combined, the ratio of losses of loss-making enterprises to total output of all enterprises decreased from an all-time high level of 14 per cent in 1998 to 6 per cent in 2000. This compares with a decrease from 16 per cent to 7 per cent for all SOEs, and from 14 per cent to 7 per cent for all formal industrial enterprises. These figures indicate that, contrary to orthodox accounts,

Table 2.2 Liability-to-asset ratio and loss-to-output ratio, 1995, 1998, 2000

\begin{tabular}{lccccccc}
\hline \multicolumn{5}{c}{ Liability-to-asset ratio } & \multicolumn{2}{c}{ Loss-to-output ratio } \\
& Formal & SOEs & LEs & Formal & SOEs & LEs & \multicolumn{1}{c}{ LMEs } \\
\hline 1995 & $65.31 \%$ & $65.81 \%$ & $61.42 \%$ & $11.68 \%$ & $11.68 \%$ & $6.30 \%$ & $8.58 \%$ \\
1998 & $63.19 \%$ & $63.74 \%$ & $60.24 \%$ & $13.84 \%$ & $16.22 \%$ & & $14.10 \%$ \\
2000 & $60.12 \%$ & $60.34 \%$ & $57.08 \%$ & $6.66 \%$ & $6.93 \%$ & & $5.56 \%$ \\
\hline
\end{tabular}

Sources: Zhongguo Gongye Jingji Tongji Nianjian (China Industrial Economics Statistical Yearbook), Zhongguo Tongii Nianjian (China Statistical Yearbook), and Zhongguo Tongji Zhaiyao (China Statistical Abstract), various years; and Renmin Ribao (People's Daily), 2 December 2002.

Notes

LMEs = large- and medium-scale industrial enterprises. Loss refers to the losses of loss-making enterprises. Output refers to output value of all enterprises in each category, and is proxied by sales revenue minus cost. 


\section{Dic Lo and Russell Smyth}

Chinese industrial enterprises, and LEs in particular, have survived the most difficult period of reform quite well.

Long term, it is perhaps even more important to note that, along with Chinese industry as a whole, since 1998 LEs have managed to reverse the trend of secular decline in profit rates. This is no small achievement given the strong correlation between the (declining) industrial profitability and the (also declining) industrial investment since the mid-1990s. In this respect, the strong performance of LEs relative to other firms is of particular importance. The pretax profit rate of LEs has exceeded that of Chinese industry as a whole, by a substantial margin, throughout the reform era. Moreover, available evidence suggests that the relatively good performance of LEs is not a reflection of their monopolistic position in the market. Up until 1998, the profitability gap between LEs and the industrial total had tended to widen despite the process of progressive marketization of the economy. Even in the least liberalized industrial sectors, competition became acute in the 1990s. In the extreme cases of the petroleum extraction industry and the tobacco processing industry, for instance, by 1997, there were 83 enterprises (of which 52 were SOEs) and 398 enterprises (of which 289 were SOEs), respectively, making it difficult to characterize them as monopolistic. Even if these two sectors were excluded, the pre-tax profit rate of LEs still exceeded that of the industrial total in most years of the reform era.

\subsection{Institutional reform: depictions and assessment}

These empirical observations should be seen in the context of the peculiar characteristics of China's systemic transformation. An important feature of China's reforms is the gradual shift in the orientation of the state from socialist commitments to developmental concerns. The massive shrinkage of the output share of SOEs in Chinese industry is a clear indication of the decline in socialist commitments, given that SOEs are by nature the most socialist in the economy in terms of the positions of workers in both production and distribution.

\subsubsection{Promoting state-owned big business}

The Chinese government's approach to promoting large-scale SOEs, which was reaffirmed at the Fifteenth Congress of the Chinese Communist Party (CCP) in September 1997, is reflected in the slogan zhuada fangxiao ('grasp the large and let go of the small'). The centrepiece of the zhuada reforms is the promotion of a number of large state-owned enterprise groups (qiye jituan) including 120 groups known as the 'national team'. Running parallel with these reforms, in 1997 the government announced preferential support for 512 key large and medium enterprises, at least 74 of which were core members of the national team (XGTGZ 1999: 325-333). While these 512 firms accounted for just 1 per cent of all SOEs, they were responsible for 55 per cent of assets, 60 per cent of sales and 80 per cent of taxes of the state industrial sector (CDBW, 14 January 1998, cited in Sutherland 2001). Supporting the establishment of the 120 
enterprise groups and 512 key large and medium-sized enterprises, in 1994 the government began experimenting with the introduction of a 'modern enterprise system' in 100 large and medium enterprises (Smyth 1998). Of the 100 enterprises, 28 were classified as super-large and 67 as large and medium-sized enterprises. Together the 100 enterprises employed 1.5 million people and most were members of large enterprise groups in their own right (Sutherland 2001).

The retention of a sizeable and expanding sector of LEs under state control indicates that the state has not reoriented itself to embrace the orthodox free market model. It denotes instead a primarily developmental concern: that the state is to retain control over the commanding heights of the economy and thereby to direct the path of overall development, amid the increasing integration of the country into the world market. This is in the spirit of the East Asian, or South Korean-Japanese model of late industrialization (Amsden 1989, Wade 1990, Burkett and Hart-Landsberg 2000). It is also in this spirit that the Chinese state has adopted a policy of promoting the development of Korean-Japanesetype business conglomerates. Paradoxically, rather than being deterred by the outbreak of the East Asian crisis, it was precisely in the years 1998-2000 that the policy made considerable headway in promoting enterprise groups. As can be seen from Table 2.3, which gives data on relative value-added per firm (that is the evolution of firm scale), there was a trend of relative decline of LEs until 1998 because of the market reform. In the subsequent years, though, the trend was reversed: the average scale of LEs relative to the industrial total increased from 290 times in 1998 to 332 times in 2001.

The late industrialization perspective suggests that there is considerable precedent for building large firms and diversified business groups, based on the experience of other late industrializing countries (Amsden and Hikino 1994). Amsden $(1989,1992)$ stresses that the development path of conglomerates in late industrializing countries has been different from that in industrialized countries. Large firms in industrialized countries first specialized in producing a

Table 2.3 Relative per enterprise value-added, 1985-2001

\begin{tabular}{lllll}
\hline & Formal/Total & SOEs/Total & SOEs + /Total & Large/Total \\
\hline 1985 & 13 & 49 & & 669 \\
1990 & 15 & 61 & & 664 \\
1995 & 9 & 28 & & 342 \\
1998 & 28 & & 41 & 290 \\
1999 & 30 & & 45 & 302 \\
2000 & 32 & & 53 & 322 \\
2001 & 33 & & 62 & 332 \\
\hline
\end{tabular}

Sources: Zhongguo Gongye Jingii Tongji Nianjian (China Industrial Economics Statistical Yearbook), Zhongguo Tongii Nianjian (China Statistical Yearbook), and Zhongguo Tongji Zhaiyao (China Statistical Abstract), various years; and Renmin Ribao (People's Daily), 2 December 2002. 


\section{Dic Lo and Russell Smyth}

narrow product line based on core competences and then diversified into related industries. This was possible because large industrial enterprises that developed in Europe and the USA achieved Schumpeterian organizational and technological breakthroughs, which created international oligopolies. However, as its definition suggests, late industrialization is a process devoid of innovation (Amsden 1992). Hence, in contrast to firms in industrialized countries, firms in late industrializing countries have been forced to import and adapt foreign technologies and depend on learning through doing to compensate for the absence of core innovation.

A common criticism of the zhuada process is that enterprises have been forced together via administrative mergers and, as a result, lack specific business strengths. For example, Shieh (1999: 54) states: 'There have been a number of reports that government authorities have pressured successful conglomerates to acquire loss-making enterprises - raising concerns that conglomerates are, in some cases, being formed on the basis of political considerations rather than economic ones.' However, it can equally be argued that these sorts of concerns misconstrue the real economic rationale for merging big business groups with smaller loss-making firms in transitional economies, which is precisely to foster business strengths. Nolan and Wang (1999: 190) observe:

Merger can be an especially powerful process of advancing business capabilities in a transitional economy, since business and technical skills are not so widely available as in an advanced economy. The merger process led by capable firms with advanced technological and management skills can have a powerful positive externality effect, spreading business capability more rapidly than would be the case in the absence of merger. Moreover, the pressure for mergers is reinforced in a poor transitional economy such as China. [In China there are] especially large incentives for merger that are consequent upon the underdeveloped state of market institutions, which inhibits the capacity to obtain needed inputs easily and reliably through contracts mediated by the market mechanism.

This last point has been stressed more generally by Khanna and Palepu (1997), who emphasize the knowledge-augmenting function of diversified business groups in overcoming institutional deficiencies in developing countries. Khanna and Palepu (1997) argue that business groups add value through diversification because they are better able to imitate the functions of institutions in advanced capitalist economies. Thus, while there has been a shift to more focused strategies in recent times in advanced capitalist economies, it does not follow that focused strategies will give the best results in emerging markets given institutional voids. Khanna and Palepu (1997: 51) point out:

[Groups] should not break up simply because their competitors are focused foreign companies from advanced economies. Western companies have access to advanced technology, cheap financing and 
sophisticated managerial know-how. In the absence of institutions providing these and other functions in emerging markets, diversification may be the best way to match-up with the competition.

\subsubsection{Enterprise-level reform}

The gradual shift in state orientation from socialist commitments to developmental concerns is even more clearly evident in the evolution of China's enterprise-level systemic reform. This evolution can be divided into four phases, which are well documented in the literature (see Choe and Yin 2000, Groves et al. 1994, Hay et al. 1994, Lo 1997 chapter 4, Yao 1997). The four stages of enterprise reform were the profit retention reform during 1979-83, the tax-forprofit reform during 1983-86, the adoption of the contract management system during 1987-92, and the corporatization of SOEs after 1992. This represents a gradual transition towards the establishment of a kind of institutional framework where SOEs and, to a lesser extent, collectively-owned enterprises, while institutionalizing their own interests, maintained close relationships with state authorities at various levels. The close state-enterprise relationships, though, were in no sense intended to preserve the socialist character of the enterprise system.

In the first phase of reform, in the profit retention reforms from 1979 to 1983 enterprises began to be allowed to retain part of their profits at their own disposal, rather than handing in all profits to the state authorities. They were also granted autonomy in decision-making at the margin (in other words autonomy after fulfilling state planning targets). This represented a first step of departure from the central planning system where enterprises operated under state mandatory planning and were in nature just like divisions of the state administrative apparatus.

The second phase was the tax-for-profit reform from 1983 to 1986. Its objective was to gradually substitute a uniform system of income taxes for the case-by-case bargaining regime of profit remittance, thereby leaving all enterprises to be responsible for their own profits and losses and to engage on an equal footing with each other in market competition. This reform was in pursuit of the separation of the government and enterprises, and was clearly inspired by the standard Walrasian-type notion of the 'pure' market. The problem, however, was that the state was not only the government (which collected taxes) but also the owner (which collected 'dividends' that were bound to vary across enterprises). Theoretically, it is seldom possible for the state to have an arm'slength relationship with SOEs. In practice, the state thus had to introduce an adjustment tax, the rate of which was negotiable for individual enterprises, in order to even out differences in profit-making across enterprises due to factors that were outside their control. The case-by-case bargaining regime was thus resumed.

The third phase of reform was dominated by the adoption of the contract management system. This system abandoned the pursuit of a standardized, generally applicable rate of state-enterprise division over enterprise profits. 


\section{Dic Lo and Russell Smyth}

Instead, its aim was to fix the base of tax-and-profit remittance and to allow enterprises to keep all the above-base profits - that is, it required enterprises to ensure steady increases in tax-and-profit remittance over the pre-contract amount which was taken as the base. In essence, this reform was in pursuit of the separation of ownership and control. While recognizing that the state as the owner needs to be involved in case-by-case bargaining over enterprise remittance ('dividends'), the reform sought to make the bargaining formal rather than ad hoc. And the bargaining was mainly to be done between the state and other outside interested parties through a unified contract-issuing committee, on the one hand, and the enterprise management which represented all the inside members, on the other. In practice, though, the inevitable asymmetry in information between the management and the owner tended to result in softbudgeted behaviour. There was serious asymmetry between responsibility for profits and responsibility for losses. As a result, enterprises tended to overexpand in good times, and to ask for re-negotiation over profit remittance in bad times. The state had serious difficulties in checking such behaviour, because, ultimately, it had almost unlimited responsibility for the survival of the enterprises. This systemic feature distinguished Chinese SOEs under the contract management system from capitalist corporations that operate under separation of ownership and control.

The fourth phase of reform was the corporatization of SOEs, which was initiated after 1992 with the aim of addressing this problem. It was implemented in order to separate socialist ownership, broadly defined to include the state's responsibility for the survival of enterprises, from the state-owner's property rights in enterprises. By transforming SOEs into different kinds of limited liability companies or shareholding companies, the state would have limited responsibility (up to the actual capital it invests) for enterprises - and the latter would have to be responsible for their own profits and losses, up to the point of bankruptcy. In terms of control, the state would reserve the power over the selection of the top management of enterprises and over their strategic decisionmaking. Enterprises would receive investment from the state (or, more precisely, state authorities of different levels and localities) and other legal entities, and the state would enjoy proportional returns from enterprise profits. Thus, after almost two decades of evolution, the Chinese authorities have a vision for the country's enterprise system that appears to be akin to state-owned firms in capitalist economies.

At the heart of the evolution described above is the changing relationship between the state and inside members of enterprises (that is workers), along with other main stakeholders such as local communities, the banks, and related business partners. Clearly the difficult process of negotiation over tax-and-profit remittance is no more than a bargaining over the distribution and redistribution of enterprise surplus between the two sides. More fundamentally, the unlimited responsibility of the state for enterprise survival is a reflection of the implicit contract between the state and workers, where the former was obliged to guarantee job security and a certain level of welfare provision for the latter. The corporatization of SOEs after 1992, by imposing a limit on state-owner responsibility for enterprises and enterprise responsibility for their workers, 
amounts to a breakdown of the contract. In this respect the state-sponsored downsizing drive in 1994-97 appears to be a necessary condition for the state to carry out the corporatization of SOEs. However, whereas the central government's stated policy was to transform most small and medium-scale SOEs into shareholding co-operatives, local authorities at different levels simply seized the opportunity to sell off the assets of enterprises and lay off workers thus passing liabilities onto the centre.

The corporatization of SOEs is not only about distribution. It has far-reaching ramifications for economic development as well. Up until the mid-1990s, the process of enterprise reform was characterized by a series of compromises among the main stakeholders including the state. As a result, the governance structure tended to be characterized by a complex web of checks and balances among these stakeholders, each having some degree of long-term commitment with the enterprise. This was particularly true for the workers, who had a strong collective voice in influencing the decisions of enterprises over surplus distribution as well as their bargaining positions vis-à-vis outside interested parties. It also appeared to be true for the banks, which, being the main source of external financing for industrial enterprises, continued to provide credit to enterprises despite the secular decline in industrial profitability.

On the whole, the governance structure of industrial enterprises up until the mid-1990s could be characterized as comprising a system of rigid institutions the employment relationship, the finance-industry relationship, the stateenterprise relationship, and so on - with a systemic focus on long-term orientation. What distinguished this system from the pre-reform system was the formation and consolidation of the distinctive interests of enterprises, that is of the inside members as a group, through the reform. What distinguished the system from that of a typical capitalist corporation was the indicated implicit contract between the state-owner and the inside members, and hence the state's responsibility for enterprise survival. Finally, what distinguished this Chinese system from the canonical East Asian enterprise was that, in the Chinese case, egalitarianism tended to be the norm both in intra- and inter-firm income distribution: intra-firm because of the strong collective voice of workers, and inter-firm because of the implicit contract between the state and virtually the entire urban population.

\subsubsection{Comparative efficiency attributes of institutions}

The rigid institutions described above appear in nature antithetical to the principle of the market, and hence are prone to cause allocative inefficiency. Indeed, it is precisely these systemic features that have been held responsible for the alleged economic problems indicated in the beginning of this chapter. However, the reformed enterprise system should be assessed against broader criteria of economic development, rather than just allocative efficiency alone. In the literature on East Asian industrialization, there is a range of arguments which suggest that an enterprise system of stakeholder accountability does have its distinctive advantages vis-à-vis one of shareholder accountability (see for 


\section{Dic Lo and Russell Smyth}

example Aoki 1986, 1990, 1995, 1996, Amsden 1991, Lo 1999a). This literature suggests that the long-term commitment of major stakeholders of enterprises offers potential for collective learning and intensive horizontal co-operation, leading to incremental and continuous innovations that could form an important source of enterprise competitiveness. In other words, the possible sacrifice of allocative efficiency under the long-term-oriented system could be compensated by gains in productive efficiency that would be less likely to materialize under a system of shareholder accountability.

The contract responsibility system made management in large SOEs autonomous from the government. It established a close relationship between firm performance and the prosperity of the regional authorities to which handovers were made (Nolan and Wang 1999: 186). As a result, local authorities gave managers a high degree of autonomy in return for meeting the contracted hand-overs (Nolan and Wang 1999, Nolan 2001). This in turn forged a strong link between profits on one hand and retained earnings and capacity expansion on the other (Jefferson and Rawski 1994: 52-55). When management is left to focus on long-term growth and maintaining workers' earnings, the government becomes in effect an external stakeholder. This is exactly what occurred in industries such as pharmaceuticals and steel where large-scale SOEs are dominant. Writing about Capital Iron and Steel (Shougang) and Sanjiu in the early 1990s, Nolan and Yeung (2001: 463) write that senior management 'worked for growth within their industries, rather than short-term profit maximization'. This is similar to the stakeholder arrangements in the stylized Japanese firm. In the stylized Japanese firm most of the capital is reserved inside the firm to finance further expansion; hence, the dividend to profit ratio is much lower than in other advanced capitalist economies. Most of the large SOEs and enterprise groups in China also plough back a large proportion of retained earnings to finance further expansion and modernization. For example, in the mid-1990s in Shougang 60 per cent of all retained earnings were devoted to technological modernization and improving production capabilities (Steinfeld 1998: 176). Reflecting this trend, using data on a panel of 22,000 large and medium enterprises, Jefferson et al. (2003) found that between 1994 and 1999 research and development activity in large firms became much more intensive, with the number of patents almost doubling.

This is symbolic of more general similarities between the institutional structure of large SOEs and the stylized Japanese firm in terms of promoting incremental innovation. One criticism of the main bank system in Japan is that the close relationship between the main bank and the Japanese firm is allocativeinefficient. Because the risk bearing and control functions of the main bank are asymmetric, the Japanese firm benefits from some degree of soft budget constraint. However, an important offsetting feature of the traditional Japanese firm is that the major stakeholders - banks, shareholders and workers - make a long-term commitment to the firm. Aoki (1990) argues that this promotes productive efficiency through cushioning the firm from the full rigours of financial and labour markets. The planning time horizon of the banks also tends to be longer in the stylized Japanese firm, which is conducive to collective learning or continuous incremental technical change in productivity growth. 
This is similar to large SOEs, suggesting that a trade-off exists between allocative and productive efficiency (Lo 1997, 1999a). Lo (1997: 116) states that 'the rigidities characteristic of China's reformed enterprises, particularly in terms of low labour mobility and close government ties, though detrimental to allocative efficiency, might have been conducive for productive efficiency'.

Similar to Japan, enterprise groups in China have used a high proportion of retained profits to import technologies and adapt them to local conditions. During the Meiji era in Japan (1868-1912), an important reason for high growth was the cultivation of so-called Meiji technologies from existing methods, which were better suited to local climatic conditions than their imported western counterparts. After the Second World War Japanese enterprises also imported technologies from Europe and the United States, making improvements through incremental innovation. The practice of importing and reverse engineering second-hand foreign technologies to meet local conditions has been well documented in a number of large Chinese SOEs. For example, Nolan and Yeung (2001: 446-447) and Steinfeld (1998: 201-202) discuss how the giant Shougang made large purchases of low-price second-hand equipment from Europe and the United States (circa 1950) and then updated it with a four-stage investment process.

These arguments can be generalized to suggest a trade-off between the concepts of stakeholder accountability and shareholder accountability. Here we provide a brief outline of the conceptual framework (a detailed exposition of the conceptual framework is provided in Smyth and Lo 2000 and Lo and Smyth 2004). The starting point is that there are three basic organizational forms: markets, hierarchies and networks. These organizational forms are founded on different concepts of the division of labour and have their own efficiency attributes. The two principles of the division of labour are the detailed division of labour and the social division of labour. The detailed division of labour refers to the hierarchical relationship between capital and labour within the firm. The social division of labour refers to the relationship between capitalists in competition with each other as independent entities (Fine 1982: 41). The two concepts can also be considered in terms of their respective cognitive bases. For the detailed division of labour, productivity growth is generated by the separation of conception and execution within the confinement of a given cognitive framework. The concrete manifestation in modern economies is the transition from the craft system to the factory system, and this transition has often been interpreted as being driven by the expansion of the scale of exchange. This is reflected in Adam Smith's (1776 [1976]) often quoted dictum that 'the division of labour is limited by the extent of the market'. In contrast, the social division of labour, which is characterized by the integration of conception and execution and productivity growth, is generated by the process of exploration between deepening the given cognitive framework and selecting a new cognitive framework (see Piore 1992: 165-167).

The market and hierarchy organizational forms are based on the principle of detailed division of labour because of the central importance that both attach to the notion of information. The relevant efficiency attribute is allocative efficiency or economies of scale. The network organizational form is based on 


\section{Dic Lo and Russell Smyth}

the principle of the social division of labour because it centres on the notion of knowledge which is generated through collective learning. The relevant efficiency attribute is productive efficiency or economies of scope. The creation of knowledge stems from self-motivated learning by participants in the production process and from active co-operation between them. The concepts of reciprocity and social norms which underpin networks have been suggested as being responsible for re-integrating the social division of labour (Piore 1992). Both reciprocity and social norms required for facilitating collective learning are outgrowths of long-term relationships and are not reducible to individualistic rational choices.

To sum up the preceding discussion, a corporate governance structure of stakeholder accountability, as evident in the stylized Japanese firm, is based on networks and exhibits the attribute of economies of scope founded on the principle of the social division of labour. Meanwhile, a structure of shareholder accountability, reflected in the stylized Anglo-American model of the firm, is based on either markets or hierarchies and exhibits the attribute of either allocative efficiency or economies of scale, both of which are founded on the detailed division of labour. The comparative efficiency of shareholder and stakeholder accountability depends, ultimately, on the appropriate match or otherwise between the organizational forms and the external, demand-side environment.

Shareholder accountability is consistent with the situation where the degree of ex ante planning is zero. In this scenario the market is characterized by perfect competition and the external environment is highly unstable from the perspective of individual firms. Under such circumstances, the market is the appropriate institutional arrangement. Firms in perfect competition have a shortterm orientation and have institutional arrangements that are conducive to providing the highest degree of flexibility. This allows the firm to make a series of adjustments in response to rapid fluctuations in the external environment. When the external environment is unstable, such firms are comparatively efficient, and the main source of their competitiveness is allocative efficiency. Shareholder accountability is also consistent with the situation at the opposite end of the spectrum where the degree of planning is high and flexibility is not an important factor in accounting for the comparative efficiency of the firm. In this scenario hierarchies are the appropriate institutional mode. The focus of the firm is on ex ante and centralized planning, which has the advantage of maximizing the comparative efficiency of the detailed division of labour within the firm. The main source of competitiveness is economies of scale.

Stakeholder accountability is consistent with the intermediate case where the external environment is continuously changing in a steady but not violent fashion. In this situation networks are the appropriate institutional mode. The focus of the firm is on decentralized collective learning, which has the advantage of generating continuous and incremental innovations both to adapt to and to govern the changes in the external environment. In these circumstances, the main source of competitiveness is economies of scope.

From this theoretical reasoning, and based on the observations on performance indicated in the previous section, it is thus possible to make an 
overall assessment of the corporate governance of Chinese industry depicted above. In a nutshell, in the context of China's specific pattern of economic development and systemic change, the governance structure of large-scale enterprises has appeared to be on balance conducive to the creation of comparative efficiency vis-à-vis the rest of Chinese industry. We conclude this section by stressing three features of the reforms, which are consistent with our argument.

First, against the backdrop of the institutionalization of their distinctive interests, LEs have still continued to maintain close and long-term relationships with their stakeholders. This is unlike small and medium firms (SOEs or otherwise) which have now been mostly marketized. This point can be illustrated with reference to the extreme case of firms which have been listed on the stock market. While being the most marketized of all LEs, these firms have retained close and long-term relationships with their stakeholders (see ZGFB 2000, chapters 26 and 28). Second, market demand in most Chinese industries has been steadily expanding, although at different speeds in different periods, despite the widespread existence of excess capacity since the early 1990s, which has been caused by the lack of exit options for failed firms. Third, in an environment of expanding market demand cum excess capacity and hence acute competition, LEs have done better financially than small firms (Cheng and Lo 2002). The connection between relative performance and the characterized institutions rests on two observations. One is that although profitability indicators are much better for LEs, loss-making indicators are similar between firms of different scales. The other observation is that the profitability gap between LEs and other firms was much bigger in the boom periods of 19861988 and 1993-1997 than in the demand-stagnant period of 1998-2000. Both of these observations are consistent with LEs having more rigid institutional arrangements and, unlike small firms, not having an exit option.

\subsection{Future prospects and conclusions}

The exposition in the preceding section, while delineating the strength of the process of industrial restructuring and the evolution of corporate governance in Chinese SOEs, also clarifies their weakness. The comparative efficiency of the reformed enterprise system, as indicated, depends on its appropriate match or otherwise with the external demand-side environment. The implication is that the appropriate match that has been achieved so far over the reform era in China is inherently unstable, and the future prospects rest on the capability of enterprises in continuously adjusting their institutional arrangements in relation to the changing environment. Anything less than that could result in severe difficulty for enterprises, as was clearly evident in the developments in the second half of the 1990s.

Prima facie, the outbreak of the East Asian financial and economic crisis was the immediate cause of the worsening demand conditions faced by Chinese industry, particularly for LEs - a main symptom being the fact that deflation began to occur in China from late 1997. However, it is worth noting that demand 


\section{Dic Lo and Russell Smyth}

deficiency had already been very serious in the preceding years. The gradual erosion of the egalitarian pattern of income distribution under the marketoriented reform had undermined mass consumption in the domestic market. The enterprise downsizing drive in 1994-97, by causing mass unemployment and thereby the slowdown in the expansion of consumption, only exacerbated the situation. This resulted in a fundamental re-orientation of state economic policy from 1998 to 2000, from pursuing fast marketization to the adoption of a range of market-supplanting anti-crisis policies, which stabilized the trend of worsening demand deficiency. Central to this change in focus were Keynesiantype fiscal stimulus policies, welfare-state policies, measures for revitalizing SOEs and tighter regulations over external transactions. With these policies Chinese industrial enterprises, and LEs in particular, have since been able to substantially improve their financial performance.

Looking forward to the future, one might speculate that the need for Chinese industrial enterprises to adjust their institutional arrangements will become even more pressing. Now that most small and medium-scale SOEs have been liquidated, and that the collectively-owned sector is in a state of stagnation, the pattern of income distribution is likely to become increasingly uneven. Mass consumption in the domestic market is thus likely to be undermined. Chinese industrial enterprises are also facing direct competition from multinational corporations following China's accession to the World Trade Organisation in late 2001. The transition towards a largely market-based system, in short, implies that demand deficiency is likely to be a prevailing feature. In this context, a major source of hope for Chinese industrial enterprises is the possibility of opening up foreign markets as a supplementary source of demand. This is not all wishful thinking. There is ample evidence that, after two and a half decades of reform and rapid economic development, Chinese industrial enterprises have largely increased their international competitiveness in a wide range of industries. How well they will perform into the future will be an even more severe test for the comparative efficiency of their corporate governance structure. 


\title{
3 Regional comparative analysis of China's banking system
}

\author{
Kym Brown and Michael Skully
}

\subsection{Introduction}

China's banking system is massive, providing some US $\$ 2.1$ trillion of its domestic financial sector's US\$3.3 trillion at the end of 2002. Faced with the massive inefficiencies of the banking system that formally supported stateowned enterprises (SOEs), and a substantial informal banking sector that grew along with economic growth, the Chinese government had few options but to agree to more foreign participation by signing the World Trade Organisation (WTO) agreement on Trade in Services. Like other transitional and developed economies, China is in the process of reforming and liberalizing its banking sector from full state ownership. Inextricably connected with this banking reform are social and economic issues concerning SOEs, which had traditionally received funding from state-owned banks (SOBs), regardless of credit risk. Quandaries with such moves include the SOBs then employing fewer staff and requiring risk assessment of potential outcomes - a change in culture from past practices reliant on state direction and full employment for the people. ${ }^{1}$

Reform of the Chinese banking and financial system covers several areas. First, we review the bank restructuring literature for transitional economies. Claessens (1996) recommends that new entrants to the banking sector may help to invigorate the prior centrally planned system and that SOBs could be privatized. At the same time regulatory, legal and accounting standards need to be improved to support market-based systems, and compliance needs to be strengthened. Dziobek and Pazarbasioglu (1997) highlight an important policy decision that losses need to be suitably shared between the state, the banks and the public. A key indicator of progress is that a country publishes statistical data (see Jaffee and Levonian 2001). Based on Eastern European and Central Asian countries' experiences, Zoli (2001) found that the fiscal cost of restructuring a system depended on the size of bad loans inherited from the centrally planned system and weaknesses in the restructuring policies. The usual pathway for transitional economies begins with the provision of entrepreneurial finance, including self-financing from friends and family, trade credit and micro finance from the government. Then, as a firm grows, it will be able to access bank finance. Finally capital markets develop, domestically and perhaps internationally (see Bonin and Wachtel 2003). 
Second, the foreign bank entry literature cites a number of advantages for their participation within an economy. These advantages include: the cost of finance for domestic firms; the fact that foreign banks will be more independent of the government; improvement of existing banks through the efficiency, technology and management skills of foreign banks; increased competition; and further development of bank supervision and the legal system (see Peek and Rosengren 2000; Crystal, Dages, and Goldberg 2001). Other possible advantages include encouraging the presence of rating agencies and auditors, and the fact that foreign banks are not as vulnerable to macroeconomic shocks within any one host country (see Montgomery 2003). One disadvantage, however, is the reduced ability of regulators to control the banking system (see Buch and Golder 2001). Initially foreign entry was thought inappropriate; however, with rapid development of banking systems in Hungary, Poland and the Czech Republic following such a policy decision, other countries followed (see Bonin and Wachtel 2003).

All Chinese-influenced economies in the East Asian region were net providers of international bank funds in 2002. Most banking markets within the region have decreased in size since the 1997 financial crisis period; however, China and South Korea have both grown with the former by some 50 per cent. China and Indonesia are the riskiest markets, with Chinese non-performing loans (NPLs) estimated as high as 45 per cent of total loans. While the Chinese people do trust Chinese banks, inefficiencies and direct controls have encouraged the development of a sizeable informal market. It is suggested that supervision be expanded with more bank supervisors per bank. Foreign banks are expected to maintain their operations in niche markets even with further reform and accession possibilities.

This chapter seeks to provide a comparative overview of the Chinese financial system, with an emphasis on the banking system and its reform progress. Initially an overview is provided of current reforms. Second, the Chinese banking system is compared with those of other economies in the region. Finally a conclusion is provided, with conjectures about the future possibilities of Chinese banking reform.

\subsection{Developments in the Chinese Bank reform process}

Before 1978 one mono-bank, the People's Bank of China, served as both the central and commercial bank. In 1979 four state banks were established. ${ }^{2}$ These four now dominate Chinese banking, with 90 per cent of banking assets and 70 per cent of the lending in 2000 (see Bonin and Huang 2001). Further reforms included the establishment of three policy banks in $1994^{3}$ to assume the nonprofitable funding role of SOBs to SOEs. However, the funding of SOEs by SOBs continues. By 2001-2002 non-SOEs were receiving approximately 50 per cent of funding from SOBs (see Standard and Poors 2003b). A number of jointstock owned commercial banks have evolved since 1986. Also there are over 100 regional, provincial and city commercial banks with joint-stock ownership. Ownership generally consists of provincial governments, state enterprises and 
some foreign banks. International trust and investment corporations were created to facilitate foreign trade and investments. Rural areas and some cities are serviced by over 42,000 credit cooperatives. Lastly, foreign banks are found in the eastern export-oriented cities (see Asiamoney 2002). ${ }^{4}$

NPLs need to be removed from bank balance sheets, as has already been done to some extent with four asset management companies (AMCs) ${ }^{5}$ in China for the four SOBs. In 1998, the government injected RMB40 billion for them to purchase NPLs from SOBs, thus providing some relief, although levels have persisted (see Bonin and Huang 2001). Their working out of loans has been difficult, with the AMCs finding the NPLs difficult to offload even to foreign purchasers (see Ma and Fung 2002). Limited creditor rights within the current legal system are part of the problem, as is the cultural preference not to sell equity to foreign interests. AMCs also employed debt-equity swaps, whereby the SOE debt (outstanding prior to 1996) was swapped for equity. Some RMB1,400 billion was provided to some 600 SOEs in this manner by 2001 (Steinfeld 2001). However, while the balance sheets of the SOEs improved, their fundamentals (such as efficiency) did not change (see Steinfeld and Hulme 2000).

The AMCs' removal of NPLs in 1999 and 2000 helped state banks' balance sheets. The reported NPL levels still remain high, however. This may be because of new NPLs and better disclosure of previous problem loans. Past problem loans had limited provisioning, as the Ministry of Finance (MoF) imposed a limit of 1 per cent for bad loans, given that taxation was tied to bank revenue. ${ }^{6}$ This has supposedly now been lifted to 2-3 per cent, but the Central Bank, the People's Bank of China, and the new regulator China Banking Regulatory Commission are pressing for NPLs now to be reduced to 1-2 per cent per year. ${ }^{7}$

One of the latest reforms has been the establishment in March 2003 of a bank regulator separate from the central bank, called the China Banking Regulatory Commission. Regional offices will be established for the regulator to aid supervisory practices. Another development is a national payments system for credit cards that prohibits foreign credit cards, and so can be used by the government initially to keep domestic customers loyal to domestic banks. Foreign banks will be able to compete in the future. Further reforms include a trial of portfolio performance-based remuneration for bank managers in Wenzhou city, where illegal financiers have previously been the main provider of funds. ${ }^{8}$

Informal credit markets are common in transitional states, even though they charge higher rates (see Chow and Fung 2000). Table 3.1 illustrates the level of informal credit under the heading 'other'. If informal financing numbers could be included, perhaps China would rival Japan more closely than expected in financing efforts simply within its borders. According to Tsai (2002), less than 1 per cent of the national banking system was funding private enterprise at the end of 2000. Therefore entrepreneurs were relying on informal sources including interpersonal borrowing, trade credit, credit cooperatives and private unsanctioned banks (which are illegal). Furthermore, Tsai challenges the notion that reforms in property rights are required for economic prosperity given the 
successful growth of China based on the current system with high levels of informal credit. ${ }^{9}$

Arduous restrictions have been placed on foreign bank participants. A nonoperational representative office has to be established for two years before a bank may apply for branch approval. Foreign banks must have at least US $\$ 20$ billion of assets globally and minimum capital of RMB300 million locally. Other requirements include capital levels, and operations were limited first to single branches, wholly owned subsidiaries or joint sino-foreign joint ventures in specific cities. In addition, foreign banks have only been permitted to service foreign clients, joint-venture enterprises or Chinese nationals and enterprises for import/export services or approved foreign currency lending (see OECD 2002). Capital restrictions also apply in China whereby profits only can be moved offshore.

China signed the WTO agreement in December 2001. The current bank reform process is stepped from 2002. Initially foreign banks were allowed to manage all foreign currency transactions with foreigners and after one year also with residents. Two years later, RMB transactions with Chinese firms are to be allowed, whilst by 2006 foreign banks should be able to accept Chinese deposits without geographical restrictions. Prior to that they needed to fund loans with foreign capital (see: Li and Yau 2001, Bang 2002). Therefore Chinese banks need to be reformed and competitive by 2006 when geographical and currency restrictions will no longer apply. Stephens (2003) believes, however, that the Chinese authorities will slow their reform process owing to concerns over growing NPLs. Proposals against the character of the WTO agreement include limiting RMB lending by foreign banks based on the size of the bank rather than credit, and limiting the number of new branches each year.

Table 3.1 Financing patterns

\begin{tabular}{lllccc}
\hline & $\begin{array}{l}\text { Total } \\
\text { External } \\
\text { Finance } \%\end{array}$ & $\begin{array}{l}\text { Bank } \\
\text { Finance } \%\end{array}$ & Equity \% & $\begin{array}{l}\text { Operations } \\
\text { Finance } \%\end{array}$ & Other \% \\
\hline China & 32.62 & 10.67 & 2.56 & 3.95 & 15.44 \\
Indonesia & 20.47 & 16.09 & 0.00 & 2.19 & 2.19 \\
Malaysia & 57.61 & 16.27 & 10.88 & 24.57 & 5.88 \\
Philippines & 36.03 & 19.27 & 1.69 & 10.88 & 4.19 \\
Singapore & 39.07 & 24.07 & 7.13 & 6.02 & 1.85 \\
\hline
\end{tabular}

Source: Beck, Demirguc-Kunt and Maksimovic (2002).

Note

External finance includes financing from banks, equity, operations and other finance. Bank finance includes financing from domestic as well as foreign banks. Operations finance is the sum of leasing and supplier credit. Other financing includes financing from development banks, money lenders, public sector and other sources. 


\subsection{The Chinese banking sector in comparison to regional East Asia}

A background of historical development within the Chinese banking system was provided in the previous section. This section begins with a preliminary assessment of China's macroeconomic environment before comparing its banking system with regional economies. For the purposes of analysis, Hong Kong and Taiwan are treated as separate economies to China as their banking markets are different.

The real GDP growth for China in 2001 was 10.3 per cent, which was by far the highest for the region (see Table 3.2). South Korea followed at 6.3 per cent(2002) with other countries in the sample falling well behind. Domestic credit has outstripped GDP growth progressively since 1998 and by 2002 it was some US $\$ 860$ billion more than GDP (see Figure 3.1). This is of some concern as it may reflect over-financing. The ration of quasi money to GDP was 111.1 per cent at the end of 2002, third only to Hong Kong at 217.8 per cent and Taiwan at 153.8 per cent. This ratio represents the degree to which people are willing to place their deposits within the banking system. It usually suggests the depositors' view of safety and the degree to which the system offers something close to a real return. Therefore it can be inferred that Chinese depositors currently trust the banking system. The money supply indicator M2 growth for China was 16.8 per cent, which was ahead of Australia at 13.2 per cent in 2002. Meanwhile, per capita GDP was only US\$959, the third lowest in the region, with Indonesia at US\$785 and the Philippines at US\$928 for 2002 . By analysing outstanding banking, securities and equity market financing to GDP, the size of each economy's financial sectors can be compared. China had a ratio of 264 per cent in 2002 as compared to 159 per cent in 1997. As of December 2002 China's total financing ${ }^{10}$ level ranked seventh in the same eleven-economy sample. Therefore more finance is becoming available, but its predominant form in China is by domestic bank lending. ${ }^{11}$

Initially the banking markets are evaluated with an overall assessment of their size. The measurement is based on total domestic credit by the banking sector and outstanding international bank liabilities to GDP, including off-balance sheet items for each economy. Both Singapore and Hong Kong have had high levels of bank finance outstanding, given their importance as international financial centres, although it is interesting to note their proportional decline since 1997 (see Table 3.3). By December 2002, Singapore had dropped by 36 per cent to 222.6 per cent of GDP and Hong Kong by some 20 per cent to 295.3 per cent. For Hong Kong this can be attributed to structural changes after the resumption of Chinese rule. The largest growth in domestic banking markets since 1997 was in South Korea and China, where both countries borrow relatively small amounts internationally. China had the largest levels of domestic 
32 Kym Brown and Michael Skully

Table 3.2 Macroeconomic variables (all expressed as percentages)

\begin{tabular}{|c|c|c|c|c|c|c|c|c|c|}
\hline & \multicolumn{2}{|c|}{ Real GDP Growth } & \multicolumn{2}{|c|}{$\begin{array}{l}\text { Domestic Credit } \\
\text { GDP }\end{array}$} & \multicolumn{2}{|c|}{$\begin{array}{l}\text { Money Supply } \\
\text { (M2) Growth }\end{array}$} & \multicolumn{3}{|c|}{ Quasi Money/Gross Dom. } \\
\hline & 1997 & 2002 & 1997 & 2002 & 1997 & 2002 & 1997 & 2002 & 2002 \\
\hline Australia & 3.7 & 3.5 & 85.0 & $96.9^{c}$ & 7.3 & $13.2^{\mathrm{c}}$ & 45.3 & $49.1^{c}$ & $22.0^{\mathrm{a}}$ \\
\hline China & 9.6 & $10.3^{c}$ & 106.2 & 161.6 & 17.3 & 16.8 & 76.1 & 105.8 & 38.5 \\
\hline Hong Kong & 5.0 & 2.2 & 165.4 & 143.2 & 8.4 & 10.4 & 157.1 & 217.8 & 29.2 \\
\hline Indonesia & 4.6 & $3.3^{\mathrm{c}}$ & 44.4 & 223.3 & 27.7 & 4.7 & 44.4 & 40.2 & 21.1 \\
\hline Japan & 1.9 & 0.1 & 292.3 & 119.6 & 3.0 & 3.4 & 71.6 & 53.1 & $28.0^{\mathrm{a}}$ \\
\hline Malaysia & 7.3 & -0.7 & 129.9 & 117.9 & 18.5 & 5.8 & 68.2 & 76.5 & 41.8 \\
\hline Philippines & 5.1 & $3.3^{\mathrm{c}}$ & 78.5 & 55.4 & 20.5 & 9.6 & 51.0 & 46.5 & $17.3^{\mathrm{a}}$ \\
\hline Singapore & 8.5 & $-2.0^{c}$ & 73.6 & 77.8 & 10.3 & -0.3 & 68.3 & 92.7 & $45.8^{\mathrm{b}}$ \\
\hline South Korea & 5.0 & 6.3 & 69.4 & 108.2 & 14.7 & 10.4 & 37.1 & 76.4 & 26.1 \\
\hline Taiwan & 6.8 & -2.2 & N/a & $\mathrm{N} / \mathrm{a}$ & 8.0 & $4.4^{\mathrm{c}}$ & N/a & N/a & $23.5^{\mathrm{b}}$ \\
\hline Thailand & -1.3 & $1.7^{\mathrm{c}}$ & 131.9 & 102.0 & 16.4 & 1.4 & 82.6 & 86.8 & $31.4^{\mathrm{b}}$ \\
\hline
\end{tabular}

Sources: Statistics are from the IMF IFS, ADB and EIU.

Notes

Indonesian GDP in 2002 was only \$US47.6, compared with US\$93.1 in 1997.

a Gross National Savings/GNP

b 2000

c 2001

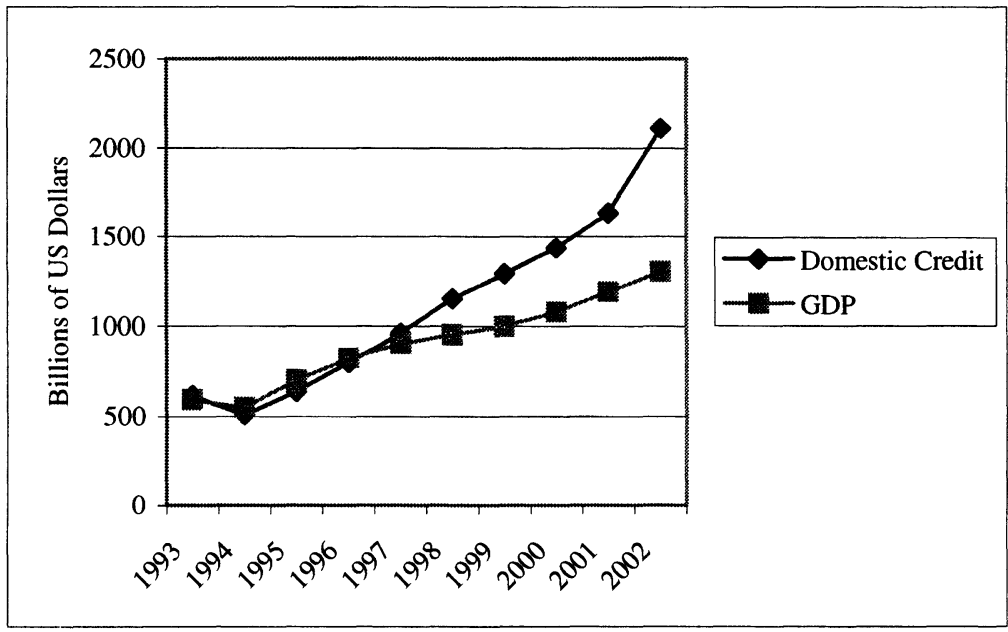

Figure 3.1 Growth of domestic credit and GDP in China 
Regional comparative analysis of China's banking system 33

credit in the region in 2002 at 170.3 per cent of GDP. At the same time, China was the smallest borrower of international funds in the region, though total Chinese bank borrowings are fast approaching those of Singapore (see Figure 3.2). The domestic Chinese market was therefore the largest in the region by 2002. Therefore, the sheer size of the Chinese banking system makes the reform process a huge task, even without its linkage to SOE reform.

Table 3.3 Bank financing across Asia (\% of GDP)

\begin{tabular}{|c|c|c|c|c|}
\hline & \multicolumn{2}{|c|}{ Domestic Credit by Banking Sector } & \multicolumn{2}{|c|}{ International Banking Credit } \\
\hline & 1997 & 2002 & 1997 & 2002 \\
\hline Australia & 85.0 & 96.9 & 34.1 & 46.7 \\
\hline China & 106.2 & 170.3 & 9.5 & 3.5 \\
\hline Hong Kong & 165.4 & 143.2 & 206.7 & 152.1 \\
\hline Indonesia & 58.5 & 61.5 & 47.5 & 19.3 \\
\hline Japan & 129.5 & 119.6 & $\mathrm{~N} / \mathrm{a}$ & 12.0 \\
\hline Malaysia & 129.9 & 118.0 & 46.9 & 53.9 \\
\hline Philippines & 78.4 & 56.0 & 38.3 & 27.7 \\
\hline Singapore & 73.5 & 77.9 & 277.2 & 144.7 \\
\hline South Korea & 69.3 & 108.2 & 40.0 & 17.2 \\
\hline Taiwan & $\mathrm{N} / \mathrm{a}$ & 143.6 & 13.1 & 14.6 \\
\hline Thailand & 131.8 & 102.0 & 73.3 & 28.1 \\
\hline Totals & $1,027.5$ & $1,197.2$ & 786.6 & 519.8 \\
\hline
\end{tabular}

Sources: IMF IFS statistics and Bank for International Settlements.

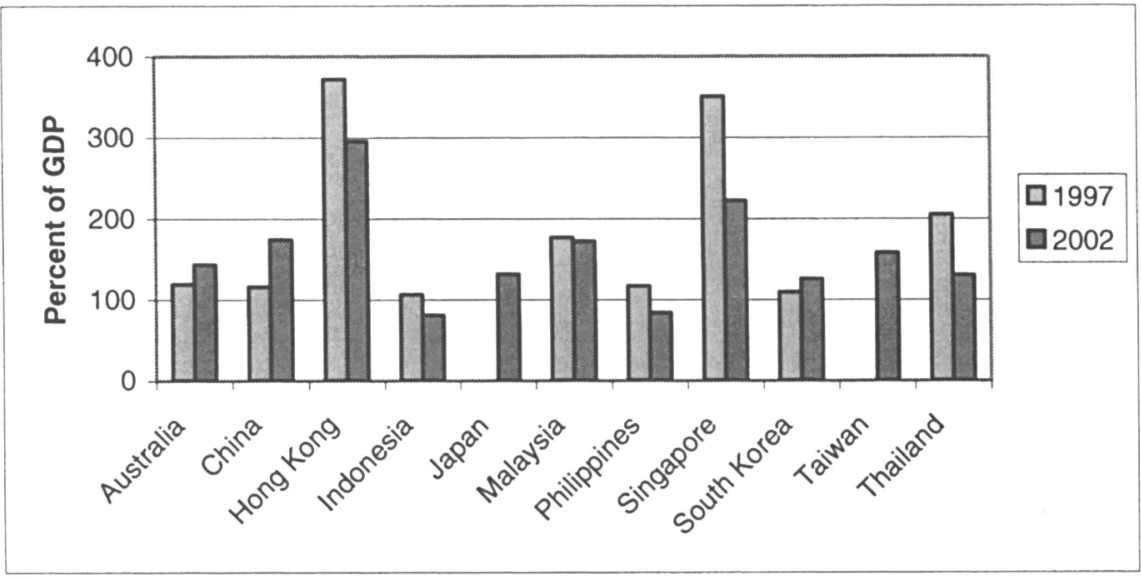

Figure 3.2 Domestic and international bank financing

Sources: IMF IFS statistics and Bank for International Settlements. 


\section{Kym Brown and Michael Skully}

Since the implementation of the banking laws of 1996, Chinese banks have been required to meet certain ratios of assets to liabilities. It is noteworthy that China, Hong Kong, Singapore and Taiwan were all net providers of funds to the international banking markets as at the end of 2002 with loan to deposit ratios below 100 per cent (see Table 3.4). Therefore it is not surprising that these economies have high savings rates on a worldwide basis. Only Japan and Taiwan were net providers in 1997, although these results do not include off balance-sheet obligations. The small ratio of loans to deposits in 2002 for China of just 35 per cent supports the correspondingly small 3.5 per cent international bank credit figure from Table 3.3.

Overall, Chinese bank performance data is difficult to obtain; however, based on a large sample, some conclusions can be drawn. The Chinese market is second only to that of Japan (as noted), with at least US $\$ 1.8$ billion in assets at the end of 2001 (Table 3.5). Although the four SOBs have a huge proportion of the market, their concentration ratios, CR3 and CR5, are in accordance with other economies. ${ }^{12}$ The interest margin is also comparable, although interest rates are controlled. ${ }^{13}$ The 2001 ROAE and ROAA appear good for China; however, the SOBs in particular had reportedly poor profitability levels in the late 1990s. The cost-to-income ratio is one measure of bank efficiency by measuring the costs incurred by a bank against the income level. China had a rate of 56.7 per cent in 2002, ranking sixth. Unfortunately as Chinese NPLs are not provisioned at their true levels, this figure may provide a misleading guide.

Table 3.4 Banking sector, international banking: loans to deposits ratio (all expressed as percentages)

\begin{tabular}{lll}
\hline & Dec 1997 & Dec 2002 \\
\hline Australia & 182 & 142 \\
China & 110 & 35 \\
Hong Kong & 194 & 50 \\
Indonesia & 302 & 103 \\
Japan & 85 & 110 \\
Malaysia & 226 & 150 \\
New Zealand & 400 & 331 \\
Philippines & 143 & 108 \\
Singapore & 138 & 77 \\
South Korea & 178 & 162 \\
Taiwan & 67 & 34 \\
Thailand & 857 & 144 \\
\hline
\end{tabular}

Source: Bank for International Settlements.

Note

External loans are liabilities and external deposits are assets to the salient country. 
Regional comparative analysis of China's banking system 35

Table 3.5 Commercial bank descriptive statistics (2001)

\begin{tabular}{|c|c|c|c|c|c|c|c|c|}
\hline & \multicolumn{4}{|l|}{ Size } & \multicolumn{4}{|c|}{ Performance (\%) } \\
\hline & $\begin{array}{l}\text { Total } \\
\text { Assets } \\
\text { (bill } \\
\text { USD) }\end{array}$ & $\begin{array}{l}\text { Equity } \\
\text { (bill } \\
\text { USD) }\end{array}$ & $\begin{array}{l}\text { CR3 } \\
(\%)\end{array}$ & $\begin{array}{l}\text { CR5 } \\
(\%)\end{array}$ & $\begin{array}{l}\text { Net } \\
\text { Interest } \\
\text { Margin }\end{array}$ & ROAE & $R O A A$ & $\begin{array}{l}\text { Cost/ } \\
\text { Income }\end{array}$ \\
\hline Australia & 445.2 & 31.0 & 64.0 & 85.1 & 1.9 & .81 & -0.1 & 69.4 \\
\hline China & $1,811.5$ & 93.9 & 64.8 & 86.2 & 2.2 & 8.8 & 0.4 & 56.7 \\
\hline $\begin{array}{l}\text { Hong } \\
\text { Kong }\end{array}$ & 449.1 & 45.0 & 71.2 & 79.5 & 2.9 & 9.4 & 1.4 & 57.3 \\
\hline Indonesia & 82.7 & 5.38 & 58.9 & 74.3 & 4.2 & 11.5 & 1.1 & 55.4 \\
\hline Japan & $5,088.0$ & 204.3 & 34.4 & 48.9 & 1.9 & -9.7 & -0.4 & 69.7 \\
\hline Korea & 477.9 & 22.4 & 46.9 & 64.7 & 2.4 & 16.9 & 0.6 & 48.4 \\
\hline Malaysia & 131.8 & 11.2 & 43.9 & 57.0 & 2.9 & 9.5 & 1.0 & 43.6 \\
\hline Philippines & 45.3 & 5.8 & 52.8 & 71.1 & 3.6 & 3.4 & 0.5 & 74.2 \\
\hline Singapore & 158.1 & 18.3 & 80.5 & 98.2 & 2.0 & 12.3 & 1.0 & 44.6 \\
\hline Taiwan & 501.0 & 37.4 & 28.7 & 42.3 & 2.3 & 1.6 & 0.2 & 53.5 \\
\hline Thailand & 134.8 & 6.7 & 50.2 & 51.3 & 1.6 & 11.6 & 2.6 & 110.6 \\
\hline
\end{tabular}

Source: Bankscope database.

Up to this point the empirics have been good for China. On the negative side, a large proportion of bank loans are unlikely to be repaid. Table 3.6 clearly illustrates that the Chinese banking market is problematic, with NPLs estimated as up to 45 per cent with only a 20 per cent recovery rate. China ranks last in this regard. The lowest levels of risk and NPLs are found in Australia, Hong Kong and Singapore. The economic and industry risk levels for China are rated 'very high' because of the risks involved when liberalizing an economy from a transitional state.

The central bank estimated NPLs for the SOBs at just 27 per cent in 2001 (see OECD 2002); independent assessments, however, were much higher. The low figure reported in 2001 was after the removal of billions of NPLs to the AMCs. Figures reported before the AMCs took over bad loans were also in line with the 25-30 per cent range, but obviously were much higher in reality. The regulator would like NPLs to reduce to 15 per cent by 2005 . While this is a commendable goal, Chinese NPL figures are often reported as what bank officials would like rather than the actual position (Standard and Poors 2003c). 
Table 3.6 Banking sector risk and non-performing loans

\begin{tabular}{|c|c|c|c|c|c|c|}
\hline Economy & $\begin{array}{l}\text { Economic } \\
\text { Risk }\end{array}$ & $\begin{array}{l}\text { Industry } \\
\text { Risk }\end{array}$ & $\begin{array}{l}\text { Gross } \\
\text { Problematic } \\
\text { Assets } \\
\\
(\%) \\
\end{array}$ & $\begin{array}{l}\text { Estimated } \\
\text { Peak NPLs } \\
\text { end 1997- } \\
1998 \text { crisis } \\
\text { (\%) }\end{array}$ & $\begin{array}{l}\text { Estimated } \\
\text { NPL end- } \\
2003 \\
(\%)\end{array}$ & $\begin{array}{l}\text { Estimated } \\
\text { Recovery } \\
\text { Rate on } \\
\text { NPLs } \\
(\%)\end{array}$ \\
\hline Australia & Low & $\begin{array}{l}\text { Moderately } \\
\text { low }\end{array}$ & $5-15$ & $<1$ & $<1$ & 70 \\
\hline China & Very high & Very high & $35-70$ & n.a. & $44-45$ & 20 \\
\hline $\begin{array}{l}\text { Hong } \\
\text { Kong }\end{array}$ & Moderate & $\begin{array}{l}\text { Mod. low - } \\
\text { mod. }\end{array}$ & $10-20$ & 7 & $5-6$ & 50 \\
\hline Indonesia & Very high & Very high & $35-70$ & $75-80$ & $15-17$ & 15 \\
\hline Japan & Mod. low & $\begin{array}{l}\text { Moderately } \\
\text { high }\end{array}$ & $15-30$ & 9 & $12-13$ & 30 \\
\hline Korea & Moderate & $\begin{array}{l}\text { Moderately } \\
\text { high }\end{array}$ & $15-30$ & 22 & $6-7$ & 35 \\
\hline Malaysia & $\begin{array}{l}\text { Mod. } \\
\text { high }\end{array}$ & $\begin{array}{l}\text { Moderately } \\
\text { high }\end{array}$ & $25-40$ & 27 & $13-14$ & 45 \\
\hline $\begin{array}{l}\text { New } \\
\text { Zealand }\end{array}$ & Mod. low & Mod. low & $10-20$ & $<1$ & $<1$ & 70 \\
\hline Philippines & High & High & $25-40$ & 30 & 30 & 25 \\
\hline Singapore & Mod. low & $\begin{array}{l}\text { Mod. low - } \\
\text { mod. }\end{array}$ & $10-20$ & 11 & $7-8$ & 75 \\
\hline Taiwan & Moderate & $\begin{array}{l}\text { Moderately } \\
\text { high }\end{array}$ & $15-30$ & 18 & 10 & 40 \\
\hline Thailand & High & $\begin{array}{l}\text { Mod. High } \\
\text { - high }\end{array}$ & $35-70$ & 50 & $28-29$ & 30 \\
\hline
\end{tabular}

Source: Standard and Poors (2003a, 2003c).

Notes

Gross Problematic Assets represent the potential peak in the ratio of gross problematic assets as a percentage of domestic credit to the private sector and non-financial public enterprises during a potential cyclical downturn.

Holz and Zhu (2002) believe that NPLs are due to firms' poor compliance with accounting standards and avoidance of debt repayment. For instance 32,140 firms, including SOEs, managed to avoid paying 18.51 billion RMB to the SOBs in 2000 simply by changing their structure. The courts have not upheld creditors' rights, thus frustrating recovery efforts. Another example is based on the period 1993 to 1995 when 1,520 enterprises were bankrupted with just a 9.2 per cent recovery rate.

Local banking supervision practices can further explain country differences. Table 3.7 shows that the Chinese banking sector is quite restricted in other activities such as securities, insurance and real estate. With further reform this will probably change. Barth, Dopico, Nolle and Wilcox (2002) performed a large-scale worldwide study on bank supervisory practices. Banks were found to be increasingly able to undertake other activities to extend 
services and profitability. These activities were classified under securities, insurance and real estate. ${ }^{14}$ Many countries place restrictions on banks' insurance and real estate activities to some extent (see Barth, Dopico, Nolle and Wilcox 2002); China is therefore not unique in that regard, but reportedly imposes higher levels of restrictions.

Following from Table 3.7, which illustrates the tight restrictions of Chinese banks, an analysis of a sample of bank balance sheets (from the Bankscope database) can clearly indicate how the various banking markets differ in their use of debt securities and equities (see Table 3.8). Security investments (assets) by Chinese banks have fallen from US $\$ 4.1$ billion in 1997 to just US $\$ 0.9$ billion in 2001, ranking Chinese bank use of debt securities assets the lowest in the region. Nevertheless, Chinese banks have issued an increasing quantity of shortterm money market instruments (liabilities) and reduced amounts of 'other funding', which in this case was mainly classified as 'other bonds' (not convertible bonds). Since the 1997/98 financial crisis banks in the region have increasingly been issuing domestic debt securities.

Table 3.7 Banking powers across countries

\begin{tabular}{lllll}
\hline Economy & $\begin{array}{l}\text { Securities } \\
\text { Activities }\end{array}$ & $\begin{array}{l}\text { Insurance } \\
\text { Activities }\end{array}$ & $\begin{array}{l}\text { Real Estate } \\
\text { Activities }\end{array}$ & $\begin{array}{l}\text { Index of } \\
\text { Restrictiveness }\end{array}$ \\
\hline Australia & Unrestricted & Permitted & Restricted & 6 \\
China & Prohibited & Restricted & Prohibited & 11 \\
Indonesia & Permitted & Prohibited & Prohibited & 10 \\
Japan & Restricted & Prohibited & Restricted & 10 \\
South Korea & Permitted & Permitted & Permitted & 6 \\
Malaysia & Permitted & Permitted & Restricted & 7 \\
Philippines & Unrestricted & Permitted & Permitted & 5 \\
Singapore & Unrestricted & Permitted & Restricted & 6 \\
Taiwan & Unrestricted & Prohibited & Prohibited & 9 \\
Thailand & Permitted & Permitted & Permitted & 6 \\
\hline
\end{tabular}

Source: Barth, Dopico, Nolle and Wilcox (2002).

Notes

Unrestricted - the full range of activities can be conducted directly in the bank.

Permitted - the full range of activities can be conducted, but some activities must be housed in affiliates of the bank rather than directly in the bank.

Restricted - less than a full range of activities is permitted.

Prohibited - banks are not permitted to engage in the activities.

Securities activities include underwriting, dealing and brokerage services for securities and mutual funds. Insurance activities include underwriting and selling for all kinds of insurance, and acting as a principal or agent. Real estate services include investment, development and management.

Index of Restrictiveness: range 0-12 (higher values indicate more restrictions) 
Table 3.8 Commercial banks' securities and equities (billions of US dollars)

\begin{tabular}{|c|c|c|c|c|c|c|c|c|}
\hline \multirow[b]{2}{*}{ 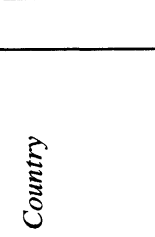 } & \multicolumn{6}{|c|}{ Assets (Investments) } & \multicolumn{2}{|c|}{ Liabilities (Issued) } \\
\hline & & 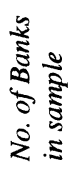 & 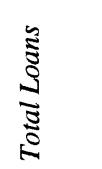 & 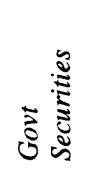 & 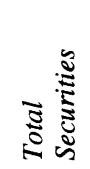 & 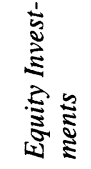 & 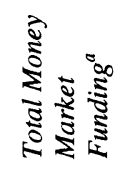 & 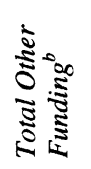 \\
\hline \multirow[t]{2}{*}{ Australia } & 1997 & 22 & 269.2 & - & 35.8 & 16.1 & 37.7 & 22.2 \\
\hline & 2001 & 21 & 312.6 & - & 40.8 & 18.4 & 51.5 & 49.1 \\
\hline \multirow[t]{2}{*}{ China } & 1997 & 28 & 728.1 & 0.07 & 4.1 & - & 0.3 & 31.3 \\
\hline & 2001 & 25 & $1,016.1$ & 0.7 & 0.9 & - & 4.6 & 7.6 \\
\hline \multirow[t]{2}{*}{ Hong Kong } & 1997 & 37 & 168.1 & - & 14.4 & 8.5 & 19.4 & 3.1 \\
\hline & 2001 & 35 & 195.3 & - & 65.2 & 19.3 & 15.4 & 2.8 \\
\hline \multirow[t]{2}{*}{ Indonesia } & 1997 & 40 & 38.8 & 0.1 & 2.8 & 0.1 & 2.3 & 12.4 \\
\hline & 2001 & 43 & 19.1 & 37.4 & 42.7 & 0.1 & 1.1 & 8.7 \\
\hline \multirow[t]{2}{*}{ Japan } & 1997 & 125 & $3,768.3$ & 271.6 & 706.7 & 301.8 & 352.4 & 495.5 \\
\hline & 2001 & 118 & $3,108.6$ & 491.7 & 982.5 & 236.4 & 325.9 & 319.0 \\
\hline \multirow[t]{2}{*}{ Malaysia } & 1997 & 25 & 52.7 & 2.8 & 11.6 & 1.3 & 7.5 & 0.9 \\
\hline & 2001 & 26 & 85.4 & 6.9 & 17.6 & 2.9 & 6.7 & 1.2 \\
\hline \multirow[t]{2}{*}{ Philippines } & 1997 & 26 & 24.9 & 0 & 1.4 & 0.4 & 5.0 & 0.03 \\
\hline & 2001 & 23 & 22.7 & - & 1.1 & 0.4 & 3.7 & 0.1 \\
\hline \multirow[t]{2}{*}{ Singapore } & 1997 & 10 & 54.9 & 0.2 & 1.2 & 2.4 & 0.5 & 0.8 \\
\hline & 2001 & 9 & 57.5 & 0.2 & 3.4 & 15.2 & 0.1 & 7.0 \\
\hline \multirow[t]{2}{*}{ South Korea } & 1997 & 15 & 145.8 & 1.5 & 33.6 & 0.8 & 18.5 & 16.4 \\
\hline & 2001 & 15 & 286.8 & 2.1 & 103.5 & 6.8 & 32.0 & 26.0 \\
\hline \multirow[t]{2}{*}{ Taiwan } & 1997 & 37 & 297.8 & 4.0 & 18.5 & 4.8 & n.a. & 5.0 \\
\hline & 2001 & 40 & 339.3 & 8.4 & 38.5 & 8.6 & n.a. & 7.7 \\
\hline \multirow[t]{2}{*}{ Thailand } & 1997 & 14 & 98.0 & 2.8 & 7.1 & 1.0 & 0.2 & 6.3 \\
\hline & 2001 & 14 & 76.6 & 23.0 & 28.8 & 1.3 & 0.02 & 7.0 \\
\hline
\end{tabular}

Source: Bankscope database.

Notes

a Total Money Market Funding includes certificates of deposit, commercial papers, debt securities and securities loaned.

b Total Other Funding includes convertible bonds, mortgage bonds, hybrid capital and subordinated debt.

China has explicit insurance for the SOBs in order to avoid massive bank runs and consequent liquidity problems or even bankruptcy for the government. Other domestic banks have implicit insurance, meaning that it is expected that the government would help repay depositor monies (they are not. however, officially obligated). According to Barth, Dopico, Nolle and Wilcox (2002), central bank supervisors are more restrictive on regulations. The structure of bank supervision has been found to have little effect on the performance of banks, however (Barth, Dopico, Nolle and Wilcox 2002). It is worth noting the low level of professional bank supervisors per bank in China at just 0.9 
supervisors per bank in 2000 (see Table 3.9). Only Singapore has a lower level, with only 0.7 per bank; that is quite well justified, however, given the geographically small country size and its large number of foreign banks.

China had the highest level of government ownership of banks in 1995 and 1970 in our sample of countries, based on the study by La Porta, Lopes-DeSilanes and Shleifer (2002). Interestingly, Taiwan was the only market with increasing levels of government ownership (see Table 3.10). Worldwide the trend is declining, and China also has experienced declining government ownership of banks. ${ }^{15}$ When the government has a larger level of bank ownership, politically directed loans are more likely to occur and so bank efficiency and development are generally lower (see Barth et al. 2002). Therefore a decline in government ownership is a signal of reform. Governments generally own banks when per capita income is low and property rights are poorly protected (see La Porta, Lopes-De-Silanes and Shleifer, 2002). Control of the banking system has enabled China's socialist government to influence large industries within the economy.

Table 3.9 Bank supervision

\begin{tabular}{|c|c|c|c|c|}
\hline Economy & Licensing Authority & $\begin{array}{l}\text { No. of } \\
\text { banks }\end{array}$ & $\begin{array}{l}\text { Total no. } \\
\text { professional } \\
\text { bank } \\
\text { supervisors }\end{array}$ & $\begin{array}{l}\text { No. of bank } \\
\text { supervisors } \\
\text { per bank }\end{array}$ \\
\hline China & People's Bank of China & 105 & 100 & 0.9 \\
\hline Indonesia & Bank Indonesia & 165 & 300 & 1.8 \\
\hline Japan & $\begin{array}{l}\text { The Financial Services } \\
\text { Agency }\end{array}$ & 294 & 350 & 1.1 \\
\hline South Korea & $\begin{array}{l}\text { Ministry of Finance \& } \\
\text { Economy }\end{array}$ & 21 & 518 & 24.6 \\
\hline Malaysia & Ministry of Finance & 34 & 160 & 4.7 \\
\hline Philippines & Bangko Sentral ng Pilipinas & 51 & 359 & 7.0 \\
\hline Singapore & $\begin{array}{l}\text { Monetary Authority of } \\
\text { Singapore }\end{array}$ & 138 & $<100$ & 0.7 \\
\hline Taiwan & $\begin{array}{l}\text { Bureau of Monetary Affairs, } \\
\text { MOF }\end{array}$ & 34 & 643 & 18.9 \\
\hline Thailand & Ministry of Finance & 13 & 503 & 38.6 \\
\hline
\end{tabular}

Source: World Bank Database, Bank Regulation and Supervision (2001).

Note

These data are not current. The new regulator for China from March 2003 has been the China Banking Regulatory Commission. 
40 Kym Brown and Michael Skully

Table 3.10 Government ownership of top 10 banks

\begin{tabular}{lccc}
\hline Economy & 1995 & 1970 & $G C 10$ \\
\hline Australia & 12.3 & 20.8 & 20.9 \\
China & 99.4 & 100 & 100 \\
Hong Kong & 0 & 0 & 0 \\
Indonesia & 42.9 & 74.8 & 42.9 \\
Japan & 0 & 6.9 & 0 \\
South Korea & 25.4 & 56.6 & 41.56 \\
Malaysia & 9.9 & 20 & 9.93 \\
Philippines & 27.2 & 52.1 & 34.41 \\
Singapore & 13.5 & 12.8 & 34.35 \\
Taiwan & 76.5 & 50.4 & 100 \\
Thailand & 17.0 & 24.0 & 21.78 \\
\hline
\end{tabular}

Source: La Porta, Lopes-De-Silanes and Shleifer (2002).

Notes

1995: Share of government ownership in top 10 banks in 1995.

1970: Share of government ownership in top 10 banks in 1970.

GC10: Sum of assets of all government owned banks divided by total assets of 10 largest banks in country in 1995.

Foreign banks in China are currently primarily involved in foreign exchange activities, but also in trade financing, wholesale banking and corporate lending (see Table 3.11). As noted earlier foreign banks are quite restricted in China. As the reform process continues however, it is not expected that foreign banks will dominate (see Stephens 2003; OECD 2002). Foreign banks have managed to take over markets to a greater extent in Latin America and Eastern Europe than within Asia. Generally foreign banks are expected to have their niche markets where they offer services that supplement domestic bank services. Domestic banks in China already have a diverse branch network across the country and strong customer relations. Given the currently poor ability to recover NPLs, foreign banks are unlikely to vie for large-scale domestic lending (see Stephens 2003). ${ }^{16}$

Business executives within China report improvements in financial market sophistication, access to credit for their business, soundness of banks and access to bank loans (see Figure 3.3). ${ }^{17}$ The reforms are clearly moving sentiments forward regarding the banking and financial system development and reform. Chinese banks, along with most regional economies, have improved the perceived strength of their balance sheets since 1998 (see Figure 3.4). Given that 1998 was at the uncertain time of the Asian financial crisis, this improvement is not surprising. 
Table 3.11 Niche business activities of foreign banks in Asia

\begin{tabular}{|c|c|c|c|c|c|c|c|}
\hline & $\begin{array}{l}\text { Project } \\
\text { Financing }\end{array}$ & $\begin{array}{l}\text { Trade } \\
\text { Financing }\end{array}$ & $\begin{array}{l}\text { Foreign } \\
\text { Exchange }\end{array}$ & $\begin{array}{l}\text { Wholesale } \\
\text { Banking }\end{array}$ & $\begin{array}{l}\text { Investment } \\
\text { Offshore } \\
\text { Banking }\end{array}$ & $\begin{array}{l}\text { Retail } \\
\text { Banking }\end{array}$ & $\begin{array}{l}\text { Corporate } \\
\text { Lending }\end{array}$ \\
\hline China & & $\sqrt{ }$ & $\sqrt{ } *$ & $\sqrt{ }$ & & & $\sqrt{ }$ \\
\hline Hong Kong & & & $\sqrt{ }$ & $\sqrt{ } *$ & $\sqrt{ }$ & & $\checkmark$ \\
\hline Indonesia & & $\sqrt{ } *$ & $\sqrt{ }$ & & & & $\sqrt{ }$ \\
\hline Japan & & $\checkmark$ & $\sqrt{ } *$ & $\checkmark$ & & & $\sqrt{ }$ \\
\hline Malaysia & & $\sqrt{ }$ & $\sqrt{ }$ & $\sqrt{ }$ & & $\sqrt{ } *$ & $\checkmark$ \\
\hline Philippines & & $\checkmark$ & $\sqrt{ }$ & $\sqrt{ }$ & $\checkmark$ & & \\
\hline Singapore & & $\sqrt{ }$ & $\sqrt{ }$ & $\sqrt{ } *$ & $\sqrt{ }$ & $\checkmark$ & $\checkmark$ \\
\hline South Korea & & & & $\sqrt{ }$ & $\checkmark$ & $\sqrt{ }$ & \\
\hline Taiwan & & & & $\sqrt{ }$ & & $\sqrt{ }$ & $\sqrt{ }$ \\
\hline Thailand & & $\sqrt{ }$ & $\checkmark$ & $\sqrt{ } *$ & $\sqrt{ }$ & & \\
\hline
\end{tabular}

Source: OECD (2002, p. 255).

Note

* primary activity.

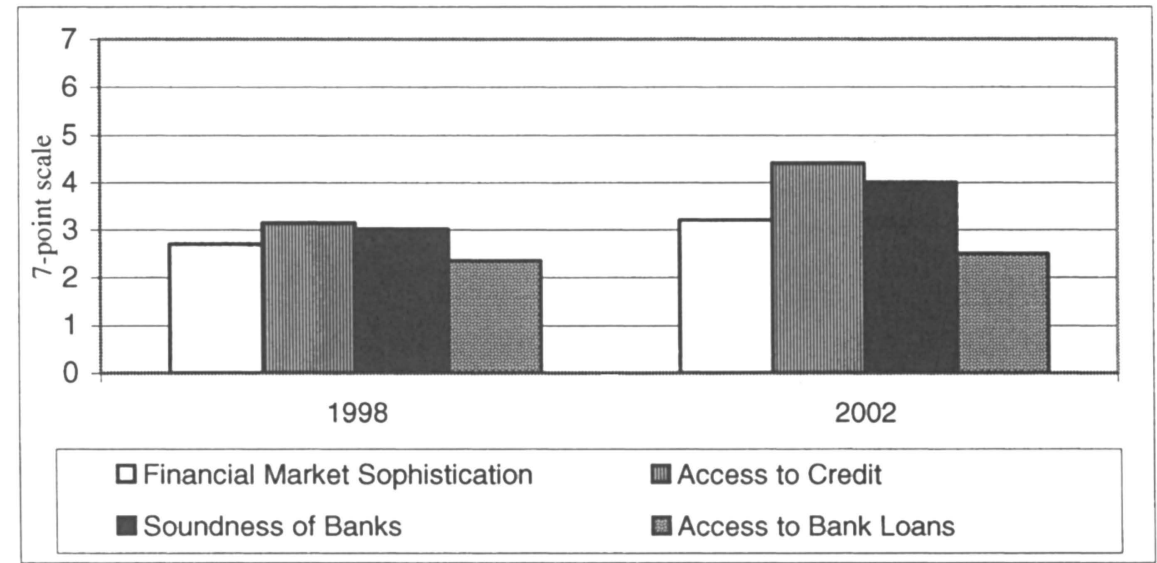

Figure 3.3 World Economic Forum: financial market indicators for China

Source: World Economic Forum $(1998,2003)$.

Internet banking may also offer possible future cost-effective solutions in China. EBucks in South Africa, for instance, part of FirstRand Bank, has implemented a new online banking system involving the combination of Gemstone and Sun Microsystems products and was able to save one third on costs compared with traditional computing online systems. Claessens, Glaessner and Klingebiel (2002) note that if internet banking develops in emerging countries, then 


\section{Kym Brown and Michael Skully}

emphasis on development of bank supervision and guarantee over deposits is not so important except for local banks. This is because of the increasing use of foreign banks with home country regulators. Table 3.12 illustrates the use of online banking; data for China were not, however, available. Online banking is limited by online computer access. The uptake of the internet in China by 2003 was only 5.2 per cent of the whole population, but even this represents a massive client market.

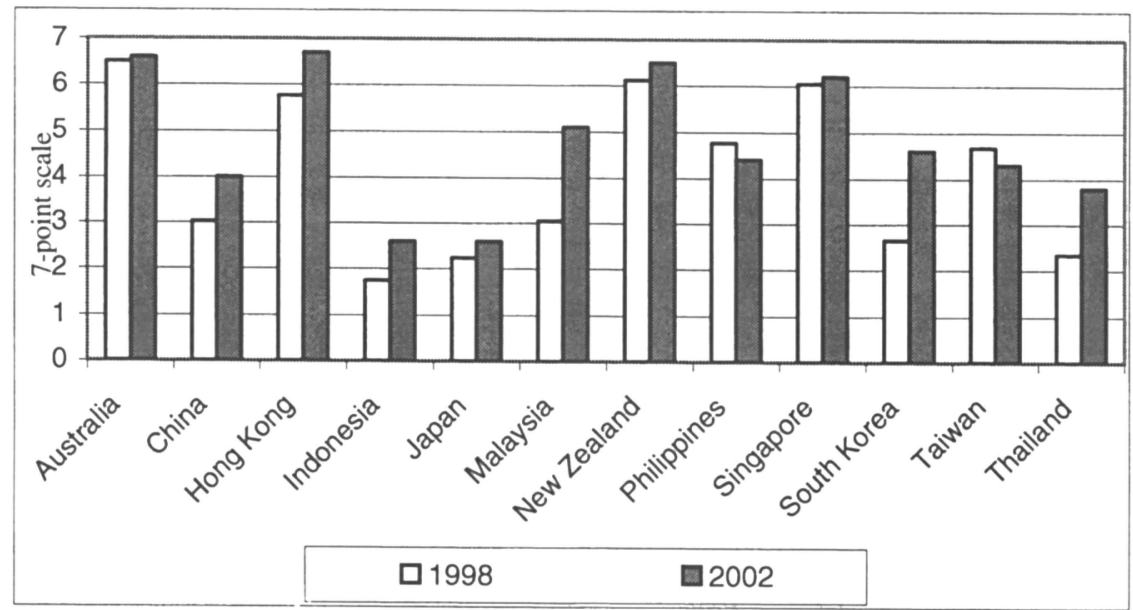

Figure 3.4 World Economic Forum: soundness of banks

Source: World Economic Forum (1998, 2003).

Table 3.12 Internet banking in Asia

\begin{tabular}{lllr}
\hline & $\begin{array}{l}\text { Banks Offering Online } \\
\text { Services }-2000 \\
(\%)\end{array}$ & $\begin{array}{l}\text { Bank Customers Using } \\
\text { Online Banking - 2000 } \\
(\%)\end{array}$ & $\begin{array}{l}\text { Internet Population } \\
\text { Penetration 2003 (\%) }\end{array}$ \\
\hline Australia & 90 & 4 & 63.3 \\
China & N/a & N/a & 5.2 \\
Hong Kong & 25 & $<2$ & 67.0 \\
Indonesia & 0 & 0 & 1.8 \\
Malaysia & 10 & $<1$ & 32.5 \\
Philippines & 15 & $<1$ & 2.4 \\
Singapore & 95 & 5 & 54.6 \\
South Korea & 90 & 3 & 56.1 \\
Taiwan & 10 & 0 & 49.7 \\
Thailand & 0 & 0 & 7.6 \\
\hline
\end{tabular}

Source: Claessens, Glaessner and Klingebiel (2002), Internet World Statistics. 


\subsection{Conclusions}

China has the largest domestic banking system to GDP in the East Asian region even with its tight prudential restrictions on other activities permissible to banks. When combined with international borrowings, it is third only to the international financial centres of Hong Kong and Singapore. Nevertheless, China faces the massive task of tackling 45 per cent NPLs that are proving difficult to recover or sell. The Chinese banking market has the highest level of government ownership in the region, although reform may gradually reduce this. Unlike in other transitional states such as Russia, people still trust the banking system and maintain extremely high savings rates (over 38 per cent and quasimoney to GDP of 111 per cent in 2002). The true debt position is not known, as the figure when reported excludes many items such as the bad loans of the SOBs.

Provided depositors do not change their views, Chinese banks are likely to continue with adequate liquidity because of the high savings rates. While the capital adequacy levels fall short of the required 8 per cent, the explicit deposit insurance for SOBs provides some security. Even as the formal financial system is developed and further regulated there is still the massive informal sector. Until the banks can offer lower cost finance to entrepreneurs, these informal financiers are likely to continue operating. The number of supervisors per bank needs to be increased, especially given the geographical size of the country. Other financing options need to be developed in China also, such as the equity and bond markets (see OECD 2002). In 2002 the government agreed to work with the IMF to improve the statistical reporting situation, which is a good signal of reform.

Statistical data (such as NPLs) need to be reported regardless of positive or negative information content. Publishing negative financial information may help to force reform. NPLs should not be further removed from the SOBs by the AMCs, which will then keep bank management under media scrutiny (Woo 2002). There have been calls for further removal of NPLs from SOBs' balance sheets; however, after the massive injection of funds to AMCs in 1998, high levels of NPLs persisted with some defaulters obtaining further finance (see Steinfeld 2001). Chinese bank managers are best left to deal with NPLs, though it is acknowledged that prior state-directed loans were not within their control.

The consensus seems to be that China will survive the reform process and that foreign banks will develop their niche markets. Cynics do not believe that China will fully comply with WTO agreements given their massive problems. Yet with continued economic growth and NPLs held constant, it would be possible for China to outgrow the problem within nine years (see Holz and Zhu 2002). Standard and Poors (2003b) provide a less positive assessment, with NPL recovery estimated to take some 23 years. 


\section{Notes}

1 In fact, analysis and research of China's financial system is stimulating because large structural issues need to be addressed, while in the future academics and economists can concentrate on micro issues such as the effects of changing interest rates by 1 per cent (see Perkins 2002).

2 The four SOBs are: Agricultural Bank of China, Bank of China, China Construction Bank and Industrial and Commercial Bank. In 1978 over 91 per cent of SOBs' loans were directed to SOEs, and in 2000 the figure was approximately 80 per cent (see Holz and Zhu 2002).

3 China Development Bank, Export-Import Bank of China and the Agricultural Development Bank of China.

4 According to Leung, Rigby and Young (2003) bank size and international diversification have a significant positive impact on the probability of entry into China. Banks from Asia have particular cultural and locational advantages and are found to be more likely to enter the market. Improved political conditions and increasing international trade are also significant determinants of the timing of entry.

5 The Asset Management Companies (AMCs) are: Xinda AMC (for China Construction Bank), Dongfang (for Bank of China), Changcheng (for the Agricultural Bank of China), and Huarong (for the Industrial and Commercial Bank). Collectively they took over RMB1.4 trillion (US\$169 billion), which was estimated as being 40 per cent of outstanding loans for SOBs in NPLs (see Ma and Fung 2002).

6 If purchasers of NPLs are uncertain about their abilities to collect, owing to factors such as inconsistencies in the courts, it becomes difficult for them to price such a portfolio; hence the difficulty in selling NPLs in China. Another problem with the NPLs was the time it took before recognizing a loan as bad. Loans were classified as 'doubtful' when they were two years overdue, and as 'bad debts' if the firm was bankrupt or in liquidity (see Bonin and Huang 2001). Rolled-over working capital loans with non-payment were not classified as bad. The international standard is now being implemented with five loan categories: pass (borrower can honour loan); special-mention (borrowers are able to service loan although specific factors may affect future ability); substandard (borrowers' abilities to service their loans are in question); doubtful (borrowers cannot repay principal and interest in full); and loss (only a small portion of principal and interest can be recovered) (see Standard and Poors 2003b).

7 As is often the case for Chinese financial statistics, poor figures are rarely reported. Banks with improved NPLs tend to release their data whilst others do not.

8 Geographically Wenzhou is located near Taiwan, and historically it has not been well funded from the provincial Zheijang government budget. Interest rates are being allowed to float with managers' performance based on loan yields and capital management. Formerly, private illegal FIs were the main providers of capital to private entrepreneurs. NPLs were extremely low for legitimate banks in Wenzhou, at just 5 per cent, with private enterprise producing some 96.7 per cent of the city's output. The government was forced to try a more capitalist position, given their lack of control over the regulation of illegal financing. The trial commenced in February 2003 (see People's Daily 2003a).

9 A problem with informal finance is that the government has no control. When these institutions fail, people are angry and may demonstrate in the streets.

10 Total financing measurement includes domestic credit by the banking sector, international bank borrowings, domestic and international debt securities and equity market capitalization. 
11 This is part of another project currently being undertaken by the authors.

12 These measure the size of the third and fifth largest banks in each country based on total assets.

13 The central bank has previously kept interest rates within the band of a set rate. For SOEs the band was 20 per cent, whilst for non-SOEs the band was 30 per cent above or 10 per cent below the set interest rate. As part of the reform process it has been proposed to lift the interest rate ceiling to allow credit evaluation policies to develop, whilst maintaining the minimum rate.

14 Securities activities included underwriting, dealing and brokerage services for securities and mutual funds. Insurance activities included underwriting and selling for all kinds of insurance and acting as a principal or agent. Real estate services included investment, development and management (see Barth, Dopico, Nolle and Wilcox 2002).

15 Worldwide in 1995, government ownership of banks was at 42 per cent, having declined from 59 per cent in 1970.

16 By the end of 2001, 233 foreign bank representative offices existed in China (Bang 2002).

17 The World Economic Forum undertakes an annual survey worldwide asking executives to rank the business environment and conditions. 


\title{
4 Solving agency problems in a cross- border environment
}

\author{
Ten years of Chinese company listings in \\ Hong Kong
}

Alice de Jonge

\subsection{Introduction}

In 1993 a new phenomenon appeared on the Chinese securities scene: the Hshare. H-shares are shares issued by enterprises located in China and incorporated under Chinese law, but which are listed and traded on an overseas stock exchange. H-shares are denominated in renminbi (RMB), the Chinese national currency, but are subscribed for and traded in the foreign currency of the market of listing. In New York, $\mathrm{H}$-shares are traded in the form of American or Global Depository Receipts, which are receipts for shares in a non-American company entitling the holder to all dividends and capital gains in relation to the underlying shares. Whatever the jurisdiction of listing, $\mathrm{H}$-shares can only be held and traded by foreign (that is non-Chinese) nationals.

$\mathrm{H}$-shares issued by Tsingtao Brewery Corporation, the first Chinese company ever to issue equities outside of the mainland, began trading on the Hong Kong Stock Exchange (HKSX) on 7 July 1993. Since then, another 77 Chinese companies have followed suit, and the number is rising rapidly (as at May 2003). To begin with, H-share issues were approved in 'batches', and separate lists of the successful applicants for listing approval were released periodically. Thus Tsingtao Brewery was part of the first batch of nine companies approved for overseas listing in 1993, followed by a second batch of 22 companies which gained the requisite approval in late 1994. By the end of the 1990s, however, individual companies had much more control over the timing of their own $\mathrm{H}$ share IPOs, and applications were being considered and decided upon separately rather than in batches. Recent examples of significant $\mathrm{H}$-share listings include the HK \$2.23-billion IPO and subsequent Hong Kong listing by China Oilfield Services (a subsidiary of China Offshore Oil) in November 2002, and China Telecom's US\$1.43-billion IPO and dual listings in New York and Hong Kong. While Hong Kong remains by far the most popular destination for Chinese firms issuing shares overseas, twelve such firms also have equities traded in New York, while three have chosen London as a second base for their overseas listings. The need for improved corporate governance standards in securities markets throughout the world has become particularly obvious in recent years. Some of the most serious problems that need to be tackled are those presented by the separation of ownership from management in the modern corporation. 
Much has been said about the problems of agency which exist when shareholders are forced to rely so much on the honesty of managers and directors for the proper management of the company. The particular purpose of this chapter is to analyse how these problems are dealt with in the unique crossborder environment of the Chinese-incorporated firm with shares listed in Hong Kong.

Chinese companies that have listed H-shares in Hong Kong are regulated by both Chinese law and Hong Kong law. On the mainland side, these firms are regulated, inter alia, by:

- Company Law of the PRC (1994)

- Securities Law (1988)

- Special Regulations of the State Council concerning Floating and Listing of Shares Overseas by Companies Limited by Shares (August 1994)

- Memorandum of Understanding between the China Securities Regulatory Commission (CSRC) and the Hong Kong Stock Exchange (1993) ${ }^{1}$

- Notice on the Implementation of Essential Clauses in Articles of Association of Companies Listed Overseas (August 1994); establishing the Essential Clauses in Articles of Association of Companies Listed Overseas

On the other side of the border, modern-day Hong Kong is generally considered to offer a well-established and transparent legal system providing efficient protection for individuals and businesses in the conduct of commercial activities. The two most important rules governing the issue, listing and trading of H-shares in Hong Kong are the recently enacted Securities and Futures Ordinance (2003) and the Hong Kong Stock Exchange Listing Rules especially Chapter 19A. These laws are policed and enforced by the Securities and Futures Commission (a statutory body) and the Hong Kong Stock Exchange (itself a company listed on the Exchange). Both regulatory authorities are vested with extensive powers of investigation and prosecution.

Under the framework established by this combination of Chinese and Hong Kong laws, there are three tiers for the exercise of decision-making powers within every $\mathrm{H}$-share enterprise. The highest level is the shareholders' general meeting which, in theory at least, exercises ultimate power to supervise and control the company's business activities, as well as the power to appoint and dismiss directors and supervisors. The second level consists of the board of directors (responsible for managing the company according to the shareholders' direction) and the supervisory committee (responsible for supervising the decision-making of directors and management). The third level is the general manager and other senior executive personnel who are responsible for the dayto-day operation of the firm. This framework, while meant in theory to protect shareholders' interests, has rarely achieved this aim in practice. The result is that holders of $\mathrm{H}$-shares have always been, and remain, exposed to a number of risks not shared by holders of other equities traded in Hong Kong.

Foreign investors have recognized the risks discussed above, and the $\mathrm{H}$-share market has long traded at a significant discount to the Chinese domestic A-share 
market as a result. In order to bolster confidence in the $\mathrm{H}$-share market, and also as part of their overall package of reforms to ensure compliance with China's protocol of accession to the World Trade Organisation, the Chinese authorities have recently implemented various measures to improve protection of shareholder rights. Laura Cha-Shih, the recently appointed vice-chairman of the China Securities Regulatory Commission (CSRC), has been particularly instrumental in maintaining the reform momentum. And some of the most important recent reforms have been those aimed at establishing a more equitable balance of powers within the tripartite structure of the modern $\mathrm{H}$-share firm.

\subsection{Changing ownership structure of listed Chinese firms}

Probably the most important risk factor for the rights of all H-shareholders is the dominant presence of the state-controlled shareholder in nearly all Chinese public corporations. At the end of 1995, state shares made up 54 per cent of the total shares of listed Chinese companies. A number of policies have since ensured a decline in this figure to 47.7 per cent of total shares by the end of 2001 (Jiang 2002). It remains true, however, that the dominance of the state-owned shareholder in most listed firms remains more than large enough to seriously compromise the independence of company management. And many of the Chinese state-owned enterprises (SOEs) that hold a controlling interest in listed $\mathrm{H}$-share firms are in financial trouble, with heavy debt burdens. As controlling shareholder, the parent SOE therefore has a strong incentive to nominate and ensure the election of directors and supervisors willing to provide various forms of assistance, even at the expense of other shareholders. As many senior officials and government members have recognized, the ability of the controlling shareholder to divert capital belonging to the listed enterprise into areas such as high-risk speculative investments in the hope of making a quick financial gain remains a serious problem. Funds have been diverted in the interests of the controlling SOE through a variety of stratagems. Large loans from the listed company to the parent SOE are all too common. In other cases, listed companies have purchased mainland-based assets, often of dubious value, from the parent SOE.

Another reason for the extra risks that holders of China-based shares are exposed to is the lack of institutional investor-presence in the Chinese securities market. What this means is that most non-state shareholders in China are individual Chinese citizens who have neither the experience nor the motivation necessary to attend shareholders' meetings regularly or monitor the performance of company management. So far as foreign holders of $\mathrm{H}$-shares are concerned, geographical distance and lack of familiarity with the on-ground operations of Chinese firms also mean that few are able to scrutinize the decisions and actions of management with any degree of effectiveness. And this remains the case despite the large number of international financial institutions, multinational corporations and professional personnel (lawyers, accountants, market researchers and investment advisers) in Hong Kong able to make credible market intelligence readily available to shareholders. 
The dominant position of state-owned entities as controlling shareholders is certainly not unique to China. However, the nature of the Chinese listing process has served to compound the risks of conflicts between controlling and minority shareholders. Listing and parent companies have often been in the same business sector, and may compete with each other. Even where there exists no direct business competition between parent and listed subsidiary after the restructuring and listing process has been completed, they almost always still have significant business and financial links with each other. In some cases, the listed company may depend on the rest of the group for distributing products or supplying raw materials. Senior managers often work for both the listed and unlisted parts of the group. This type of interdependence between listed companies and their parent firms creates fertile ground for agency problems.

Corporate control mechanisms and shareholder activism can do little to alleviate such agency problems under the existing ownership structure. The high degree of ownership concentration and the non-tradability of such a large proportion of the shares issued by a firm imply a low contestability of control.

One recent reform with the potential to alter the ownership structure problems inherent in the typical listed Chinese firm is the recent introduction of the Qualified Foreign Institutional Investor (QFII) scheme which allows foreign institutional investors, for the very first time, to invest in China's A-share markets (Provisional Measures on Administration of Domestic Securities Investments of Qualified Foreign Institutional Investors, December 2002). Since 1 November 2002, foreign investors have also been legally allowed to own nontradable corporate shares and state-owned shares of listed companies, as permitted by the Notice on Relevant Issues concerning the Transfer of StateOwned Shares and Corporate Shares of Listed Companies to Foreign Investors.

China's domestic funds, such as the 124.1 billion RMB National Social Security Fund, are also being allowed into the market, where they will further strengthen the presence of an independent, minority shareholder voice in corporate decision making (Bei 2003a).

There are, in addition, two new sets of rules - the Administration of the Takeover of Listed Companies Procedures and the Interim Provisions for Foreign Investors to Merge Domestic Enterprises - which enable foreign investors to become involved in mergers and takeovers of listed Chinese companies. $^{2} \quad$ The Using Foreign Investment to Re-organise State-Owned Enterprises Tentative Provisions also establishes a mechanism aimed at ensuring greater foreign and institutional presence in the management and operation of enterprises now controlled solely by the state.

There remain, however, a number of significant obstacles in the way of foreign investors wishing to take ownership of formerly state or corporate shares in a Chinese listed company. These include:

- the requirement for foreign investors to hold their investments for at least 12 months; and 
- the need to ensure that the proposed investment does not violate China's 'Industrial Catalogue for Foreign Investments', which lists industries closed to foreign investment. ${ }^{3}$

The changes wrought by the new sets of rules and procedures outlined above are, it would seem, likely to be very slow and very incremental in practice - not least because of the sheer inertia created by the historically heavy influence of a bulky state presence in the market. If one looks at each of the nine enterprises in the first batch of companies approved for H-share issues in 1993, for example, there have been virtually no changes to the dominant presence of the state in the ownership structure of these firms over the past ten years. But change is beginning to occur, however gradually. Tsingtao Brewery, the first $\mathrm{H}$-share to appear in Hong Kong, provides a good example of how this is happening.

By the end of 1993, after the restructuring of the company and the issuing process was completed and Tsingtao had been fully transformed from an entirely state-owned enterprise to a partly-privatized public company, the state still remained by far the largest holder of equity in the company. The state, in the case of Tsingtao, was represented by the Qingdao State-Owned Assets Bureau, which held $399,820,000$ state shares or 44.42 per cent of the company's total authorized share capital of $900,000,000$ shares in 1993. Also non-tradable, were the 53,330,000 PRC legal person shares issued by Tsingtao, comprising 5.93 per cent of total share capital and owned primarily by state-controlled 'legal persons' such as the Bank of China Shandong Province Branch (3.25 per cent of total share equity from 1993 to 2000), and the People's Construction Bank of China, Qingdao Branch (2.12 per cent for 1993-2000). There were 100,000,000 tradable A-shares of the company listed in Shanghai, and 346,850,000 tradable $\mathrm{H}$-shares listed in Hong Kong.

This ownership structure remained unchanged until 2001, when the total authorized share capital of the company was increased to $1,000,000,000$ shares. An additional 100,000,000 ordinary A-shares were issued and listed in Shanghai, bringing the total number of PRC-listed tradable A-shares to $200,000,000$. Most of the listed A-shares by this stage were held by securities investment funds and other institutional investors.

On 21 October 2002, Tsingtao entered into a strategic alliance with Anheuser-Busch Companies Inc (A-B), the world's largest brewery, and agreed to issue an aggregate of approximately USD182 million convertible bonds to A$\mathrm{B}$ in three tranches. The conversion of the first tranche of convertible bonds into $60,000,000$ additional new overseas-listed foreign-invested shares was completed by mid-2003, bringing the total share capital of the company to $1,060,000,000$ shares. The 2002 strategic investment agreement also laid the groundwork for the conversion of the second tranche of convertible bonds into $134,000,000$ additional new overseas-listed shares, and conversion of the third tranche of convertible bonds into $114,219,178$ foreign-invested shares, both within seven years.

Upon the conversion of all three tranches of convertible bonds into a total of $308,219,178$ additional new overseas-listed shares, the registered capital of the 
company will rise to RMB $1,308,219,178$ and the share structure of Tsingtao will be 1,308,219,178 ordinary shares, of which the Qingdao State-Owned Assets Administration Office will hold 399,820,000 shares, holders of domestic invested shares listed in the PRC will hold 200,000,000, legal-person A-share holders will own 53,330,000, and holders of overseas-listed foreign-invested shares will hold $655,069,178 .{ }^{4}$ In other words, state-controlled equity in the company will fall to 30.56 per cent, and foreign-controlled equity will rise to 50.07 per cent. If all goes well, Tsingtao Brewery will be transformed from a majority state-owned enterprise, to a majority foreign-owned company. And this in turn will help to transform the composition of that company's management team, as will be discussed further below.

\subsection{Protection for the rights and interests of minority shareholders}

The PRC Company Law is substantially different from Hong Kong Company Law, particularly in the area of shareholders' protection and directors' duties towards a company and its shareholders. Protection for minority shareholders is particularly notable for its absence. The lack of shareholder protection under PRC Company Law is compensated only to a limited extent by the introduction of Mandatory Provisions in the articles of association of all Chinese companies listed on the HKSX. These Mandatory Provisions resulted from joint efforts by the Hong Kong Securities Commission and the State Restructuring Commission of the PRC to facilitate the offer and listing of PRC companies overseas, and to regulate the behaviour of companies with shares listed overseas. In Hong Kong, the Mandatory Provisions are required under, and supplemented by, the HKSX Listing Rules. In the PRC they are enforced through, and supplemented by, the Special Regulations.

\subsubsection{The shareholders' meeting}

Chapter VII of the Mandatory Provisions deals with the rights and obligations of shareholders and the powers of the shareholders' meeting. Two or more shareholders with combined title to 10 per cent or more of shares with voting rights at a shareholders' meeting may require the board of directors to convene an interim shareholders' meeting or a meeting of a specific category of shareholders (Article 72). Shareholders representing 5 per cent or more of the company's shareholders with voting rights have the power to raise proposals for agenda inclusion and discussion at a shareholders' meeting.

The shareholders' meeting is the company's most powerful authority, and exercises its decision-making powers, including inter alia the power to elect and replace directors and supervisors of the company, and determine their remuneration. $^{5}$ If the company wishes to expand, reduce or otherwise alter its share capital and/or share composition, or amend its articles of association, the approval of at least two-thirds of the shareholders who are present at an annual or interim meeting must first be obtained (Article 71). The board of directors 
also cannot dispose of major fixed assets of the company without the approval of the shareholders' meeting (Article 89).

Article 47 expressly restricts the rights and powers able to be exercised by a controlling shareholder. A controlling shareholder is defined broadly, and includes any shareholder who is in a position to: control the election of a majority of directors; exercise control over 30 per cent or more of the company's voting rights, or over 30 per cent or more of the company's issued shares; or to exercise actual control over the company in any other way.

A controlling shareholder is prohibited from exercising per cent voting rights to make decisions on the following matters which harm the interests of all or some shareholders:

- To relieve a director or supervisor from his/her responsibility on the basis that this is in the best interests of the company;

- To approve that a director or supervisor, whether for his/her own interests or another's interests, expropriate company property using any means including (but not limited to) any opportunity which is beneficial to the company;

- To approve that a director or supervisor, whether for his/ her own interests or another's interests, divest other shareholders of individual rights and interests including (but not limited to) any distribution rights and voting rights, but not including where the matter is submitted to the shareholders' meeting for adoption in accordance with the company's articles of association that there be a reorganization of the company.

\subsubsection{Individual shareholder rights}

Hong Kong law permits minority shareholders to start a derivative action in the name of such shareholders in cases where directors have breached their fiduciary duties. The PRC Civil Procedure Law does not provide for any such procedure. The closest thing to a derivative action under PRC law is Article 111 of the Company Law, which gives shareholders the right to initiate proceedings in the People's Court to restrain any resolution adopted by shareholders in the general meeting or meeting of the board of directors if the resolution is in breach of any law or infringes the lawful rights and interests of the shareholders. There is no attempt in the Company Law however to guard against or deal with oppression of minority shareholders by the majority shareholders of a listed firm. It was therefore left for the Hong Kong authorities, under the HKSX Listing Rules, to ensure that all listed $\mathrm{H}$-share enterprises contain in their articles of association provisions which allow minority shareholders to commence action against defaulting directors, and which also accord minority protection similar to that available under Hong Kong law.

Until recently, however, political hang-ups and the absence of a case-law system in China have presented major obstacles to such actions (Lawrence 2002a). But then in January 2002, the Supreme People's Court in Beijing issued a circular effectively allowing stock investors to sue for compensation from 
fraudulent listed companies (Bei 2002b). The Questions Concerning the Acceptance of Civil Tort Dispute Cases Arising from Misrepresentation in the Securities Market Circular effectively lifted a four-month freeze on shareholder actions against companies found to have falsified information. More importantly, it was followed by the introduction of the necessary detailed trial guidelines to allow such actions to proceed. The Trial of Civil Damages Cases Arising from Misrepresentation in the Securities Market Several Provisions (the Provisions) came into effect on 1 February 2003. Containing 37 Articles, the Provisions not only solve important procedural questions, but also operate to significantly expand the scope of legal avenues available for aggrieved shareholders to pursue. Then in early November 2002, a 60 year-old Shanghai housewife became the first mainland stock investor to win a settlement from a mainland-listed company for false disclosure (Bei 2002b).

A new set of 'Guidelines for Corporate Governance of Listing Companies' issued by the CSRC in early 2002 also places significance on shareholder rights. Chapter One of the Code deals specifically with shareholder rights, while Chapter Two deals with the particular position and behaviour of the controlling shareholder. Article 2 states that minority shareholders should have equal status with other shareholders, while Article 4 gives all shareholders the right to protect their interests through civil litigation and other legal action. Article 8 requires that companies make a genuine effort to use modern technologies in shareholders' annual general meetings to improve shareholder participation. Also, Article 11 gives institutional investors more weight in the decision-making processes, including the nomination of directors.

\subsection{The introduction of independent directors in Chinese listed companies}

The board of directors is the critical link between ownership and corporate governance. This is the setting where governance takes place and some of the solutions to corporate governance problems can be sought. Thus, perhaps the most important implication of the dominant role of state ownership in China's listed companies is the control the government can exercise over directorship and managerial appointments and incentives, and thereby over companies' behaviour.

According to the Company Law, a board of directors should consist of five to 19 directors. The Mandatory Provisions then establish the typical corporate structure whereby the board of directors is made directly accountable to the shareholders' meeting, and under which directors, supervisors and managers owe specific fiduciary duties to the company and its owners. A certain degree of independence is required of all directors and supervisors in that they must avoid conflict-of-interest situations in the performance of their duties. Directors must make full disclosure and must not vote in respect of any board resolution in which they have a direct or indirect interest. A director, supervisor, manager or other member of senior company personnel must not incite or be implicated in the doing by any related party of any act which the director, supervisor, manager 


\section{Alice de Jonge}

or other senior management officer may not do. Related parties are defined broadly to include any family member, partner, trustee or controlled company of the director, supervisor, manager or member of senior personnel concerned. The Mandatory Provisions also specifically prohibit the company from giving any loan, or providing any guarantee to secure a loan made, to any director, supervisor or officer of the company. Share ownership and remuneration levels of directors, supervisors and senior management must be disclosed in every annual report.

In 2002, the business journal Asiamoney conducted a corporate governance poll of companies throughout the Asian region. Of 121 firms a total 197 companies polled responded to the survey; 12 of the respondents came from China. Given the care taken in designing the survey methodology and in selecting candidates for polling, the survey results can be taken as a fair representation of what counts as the 'average' Asian country, at least at a superficial level. Responses provided by the 12 Chinese firms that returned completed questionnaires indicate that in the average Chinese firm:

- the board of directors has about 15 directors, of whom perhaps three or four are independent non-executives;

- the full board formally meets for two or four meetings per year; and

- most Chinese companies take votes at shareholder meetings through a poll (proportionate to the number of shares held) rather than through a show of hands (Asiamoney 2002: 36).

By far the greatest majority of directors of $\mathrm{H}$-share companies are nominated by the controlling shareholder (the state), but this situation is beginning to change, especially for those companies such as Tsingtao Brewery which have invited a greater level of foreign involvement, and where nomination committees have been established.

In the case of Tsingtao, when the company began trading on 15 July 1993, its board of directors comprised nine directors, of which six were executive directors. Of the three non-executive directors, two came from the statecontrolled bank sector and had significant connections and experience in local branches of state-controlled banks. ${ }^{6}$

Following the 2003 conversion of the first tranche of convertible bonds issued to Anheuser-Busch into $60,000,000$ overseas-listed shares, A-B became entitled to nominate a non-executive director and one supervisor to the board and supervisory committee of Tsingtao respectively. Then, at the Extraordinary General Meeting held in August 2003, shareholders were asked to amend the company's articles of association to provide for a board of directors of 10 directors, of whom at least half would be external (that is non-executive) directors. At least one third of the board would be comprised of independent directors, with at least one of the independent directors to be an accounting professional. The supervisory committee would grow to eight supervisors, with the chairman of the supervisory committee to be elected by at least two thirds of the committee. Five of the supervisors would be shareholder representatives 
elected by shareholders in general meeting, and three supervisors would be elected to represent staff and workers of the company. There is little doubt that the role played by the state in the management of Tsingtao will be altered significantly as a result of these changes.

Other companies are also making changes to the composition and operation of their boards to ensure compliance with the 'Guideline Regarding Independent Directors in Listing Companies' (the 'Independent Director Guidelines') issued by the CSRC in August 2001, and the 'Guidelines for Corporate Governance of Listing Companies' issued by the CSRC in early 2002. It is worth noting that the Independent Director Guidelines are at least as strict as, and in some cases stricter than, similar provisions contained in the 'Code of Best Practice' found in Appendix 14 of the Hong Kong Main-Board Listing Rules. The rest of this chapter outlines the newly reformed system for independent directors in $\mathrm{H}$-share firms, and highlights some of the more important shortcomings of that system.

The Independent Director Guidelines provide that by 30 June 2003 all listed companies must ensure that at least one third of the board of directors are independent directors (Article I(3)). Independent directors can be nominated by the board of directors, the supervisory board or any shareholder holding more than 1 per cent of shares issued by the company. All nominations must first be examined and approved by the CSRC. Independent directors serve the same length of term as the other directors of the company, but can be re-elected only once and cannot serve any consecutive term in excess of six years.

In principle, an independent director may only concurrently hold the position of independent director in a maximum of five listed companies. If an independent director fails to attend a board meeting in person for three consecutive times, he or she may be removed from his or her position at the next shareholders' meeting. The only other reason for which an independent director may be removed from office is where the independent director concerned fails to meet the 'independence' requirements imposed by the Guidelines, or becomes no longer qualified to hold the position of a director as stipulated in the Company Law. A person fails to meet the 'independence' requirements of the Guidelines if:

- the person, or any of his or her relatives, holds a position in the listed company or its affiliates;

- the person, or any of his or her relatives, holds more than 1 per cent of the shares of the listed company directly or indirectly, or shares in any of the 10 largest shareholders of the listed company;

- the person, or any of his or her relatives, holds a position in any unit which holds more than 5 per cent of the shares of the listed company directly or indirectly, or any unit which ranks amongst the five largest shareholders of the listed company;

- the person met any one of the three conditions mentioned above at any time during the 12 months immediately preceding the date of nomination or appointment as independent director; or 
- the person is not qualified to act as independent director for any other reason spelt out in the listed company's articles of association or as determined by the CSRC (Article III).

The Guidelines also operate to provide independent directors with the protection of guaranteed security of tenure for the entire period of the term for which they have been appointed. If an independent director resigns or is removed from office, the CSRC in China and the HKSX in Hong Kong must be notified (Article IV of the Guidelines; and in Appendix 14 of the Hong Kong Listing Rules see Articles 7 and 12).

The role of the independent director is to safeguard the overall interests of the company with particular attention paid to protecting the rights and interests of minority shareholders (Article I(2)). Independent directors are specifically vested by the Guidelines with special powers additional to those stipulated in the Company and other relevant laws and regulations. In particular, all major related party transactions must first be vetted by each independent director before being submitted to the board of directors for discussion.?

In addition, with the approval of at least half of all the independent directors, any independent director may:

- independently engage the services of an external auditing or consulting organization;

- propose to the board of directors the appointment or removal of an accounting firm engaged by the company;

- propose the holding of an interim shareholders' meeting; or

- solicit proxies before the holding of a shareholders' meeting.

The independent directors of a listed company must provide an independent opinion on any of the following matters coming before the board of directors or the shareholders' meeting:

- nomination, appointment or replacement of any director or member of senior management;

- remuneration for directors or senior management;

- any existing or new loan borrowed from the listed company or other funds transfer made by the company's shareholders, actual controllers or affiliated enterprises that exceeds RMB 3 million or 5 per cent of the company's net assets as recently audited (including an opinion as to whether reasonable steps have been taken to recover the amount due from the debtor);

- any proposal or event that the independent director considers to be detrimental to the interests of minority shareholders; or

- any other matter as stipulated by the company's articles of association.

Finally, and importantly, listed companies must provide all necessary assistance and support, including financial assistance, for independent directors 
to properly and effectively perform all of their functions and duties (Article VII of the Guidelines; and in Appendix 14 of the Hong Kong Listing Rules see Article 9).

By 2003, nearly all listed companies in Hong Kong had established compliance with the Appendix 14 Code of Best Practice, and most contain a statement to that effect in their latest Annual Report (Webb-site 2002). The main reason for such a high level of compliance is not only that the Code is relatively easy to comply with, but also that non-compliant companies are expressly required to justify their non-compliance under paragraph 34 of Appendix 16 of the Hong Kong Listing Rules.

\subsubsection{Lack of a committee system on the boards of listed Chinese companies}

All listed companies are required by the Independent Director Guidelines to ensure that any subordinate committee established on the board of directors in accordance with the recently introduced Code of Good Governance must have independent directors making up at least one half of its membership. The Code of Good Corporate Governance establishes recommended, but not mandatory, guidelines for the establishment of a number of subordinate committees on the boards of all listed enterprises, such as a nomination committee, a remuneration committee, and/or an auditing committee.

The Code of Best Practice contained in Appendix 14 of the Hong Kong Listing Rules provides, in Article 14, that listed company boards should establish audit committees to supervise the company's financial reporting processes and internal financial controls. The committee should be appointed from amongst the non-executive directors and a majority of the non-executive directors should be independent. Article 14 then refers its readers to the 'Guide for the Formation of an Audit Committee' published by the Hong Kong Society of Accountants in December 1997 for further guidance on the establishment of audit committees.

Given the high degree of compliance with the Appendix 14 Code as mentioned above, most Hong Kong listed companies, including most $\mathrm{H}$-share companies, have now established audit committees. Other committees, such as nomination and remuneration committees, have been introduced more slowly, but they are appearing. The Tsingtao Brewery board, for example, established three special committees in 2001 - a nomination committee, an audit committee and a remuneration committee (Tsingtao 2001 Annual Report, at 29). By the end of 2002, these committees had been restructured to form a strategy and investment committee, an audit and finance committee and a human resource and corporate governance committee. As at the end of 2002, independent directors representing the majority assumed chairmanship in all but the strategy and investment committee (Tsingtao 2001 Annual Report, at 28-29).

In regards to remuneration committees, Shi and Weisert (2003: 10) have pointed out that 'most listed companies in China lack an incentive mechanism that ties the management team's performance to its compensation'. While the increasing presence of remuneration committees in listed Chinese firms may 
well help to promote the use of corporate compensation mechanisms that link executive remuneration packages to company performance, it will not be enough by itself. For example, the local Chinese market needs to develop a broader range of readily available financial instruments for companies to choose from in designing individual remuneration packages. Stock options, for example, which are commonly used in remuneration packages by Hong Kong companies, have only recently become legally available as a financial instrument in mainland China.

\subsubsection{The role and status of supervisory committees in listed Chinese firms}

Although the new Independent Director Guidelines ensure that independent directors now exist on the boards of all listed Chinese companies, no similar requirement exists in relation to the supervisory committee, despite the important role which that committee plays in the management of the firm. Under the Company Law and the Mandatory Provisions, the role of the supervisory committee is to supervise the actions and decisions of directors and officers, and in particular to:

- investigate the company's financial affairs and check the financial and business reports, profit distribution plans and other financial documents submitted to the shareholders' meeting and to commission accountants and/or auditors to assist in the verification of documents in respect of which doubts are raised;

- supervise the actions of the company's directors, managers and other senior management personnel during the performance of their duties, and to respond appropriately in respect of actions which are in violation of the law, regulations or the company's articles of association;

- represent the company in negotiations with directors or in initiating legal proceedings against a director; and

- propose the convening of interim shareholders' meetings as required (Article 108).

Supervisors are required to attend meetings of the board of directors as nonvoting delegates. Article 106 of the Mandatory Provisions attempts to ensure the independence of the supervisory committee and its members by prohibiting any director, manager or chief financial officer of the company from concurrently holding the position of supervisor. But directors or senior personnel of one company can, it would appear, hold a position as supervisor on the supervisory committee of any other enterprise, including any related enterprise.

There is also a need to strengthen the role and powers of the supervisory committee itself. Under the current system, the supervisory committee in most listed companies is considerably weaker than the board of directors, and in particular typically has almost no decisive power to stop or correct any actions of directors or senior officers. Nearly always, the supervisory committee can 
only report to the shareholders' general meeting, which may itself, as noted above, be controlled by one or two majority shareholders (Cai and Deng 2002).

\subsubsection{Lack of qualified manpower}

Another shortcoming of the independent director system in China is the fact that all too many independent directors simply do not fully understand their responsibilities or do not have the training or experience required to perform their functions effectively. In more developed markets, directors are more likely to be brought in on the basis of their professional qualifications and experience. Well qualified directors can be active advisors, and can effectively supervise the overall health of the company. In China, however

Most corporate managers still aspire to a civil service rank, and are concerned about how their superiors in the political and administrative hierarchy assess their performance. This assessment may be quite arbitrary or subjective and be based on such indicators as profits, political correctness, and the discharge of social obligations. Furthermore, local governments may have incentives that are not aligned with the plans of companies that operate on a national or international scale. (World Bank 1997a)

Recent corporate scandals in America and other developed markets show that even highly qualified and experienced directors do not always fulfil their duties or act honestly, but the lack of managerial expertise in China creates equally serious problems. A number of Chinese enterprises are solving the lack of local qualified personnel by turning elsewhere, and paying high salaries for top talent from other markets. ${ }^{8}$ But the lack of qualified personnel in China remains a problem, and it will take many years before China can provide the kind of homegrown talent it now needs. ${ }^{9}$ But steps are being taken to lay the ground for newly qualified younger professionals entering the Chinese corporate scene.

Article I(3) of the Independent Director Guidelines now provides that at least one of the independent directors must be an accounting professional (that is, a person with senior professional title or certified public accountant). Article I(5) also ensures that independent directors and nominees for independent director positions must take part in the training organized by CSRC and its authorized institutions. And Article II provides that as well as having all of the ordinary qualifications required for all persons acting as directors of listed companies, persons acting in the position of independent director must also have a basic knowledge of the operation of listed companies and be familiar with the relevant laws and regulations. In addition, all independent directors must have no less than five years' work experience in law, economics or some other professional area required by his or her performance of the duties of an independent director. These provisions reflect similar provisions in the US National Association of Securities Dealers requirements, which provide that independent directors should be able to understand the company's financial statement and that the 
issuer should make sure that the auditing committee has at least one member with a professional background in financial accounting (Leung et al. 2002).

\subsubsection{The need for an independent company secretary profession in China}

The Hong Kong Institute of Company Secretaries has argued that the development of a designated and specified company secretary profession in China is vital to ensuring that all Chinese executives are able to fulfil their company-related responsibilities effectively. At present, 'board secretaries' in mainland China are expected to concern themselves primarily with providing secretarial support to and 'serving' the board of directors and its members. In contrast, company secretaries in more developed markets have a much broader role in the capacity of secretary for the entire company, not just its board. The title 'board secretary', rather than 'company secretary' as in Hong Kong, or 'corporate secretary' as in North America, also serves to imply a lesser status, and to downgrade the overall importance of the role they perform (Leung 2003: 17). Enhancing their status would also encourage secretaries in China to develop practices such as performing unpaid, voluntary and non governmental-directed jobs in addition to fulfilling their corporate responsibilities - something that is now quite common in Hong Kong and elsewhere.

The Hong Kong Institute of Company Secretaries has provided some assistance towards the establishment of a company secretary profession in mainland China, including the introduction of professional training courses for PRC board secretaries and senior management. Most recently, a new Association of Board Secretaries of Listed Companies was established in Shanghai. But as the Hong Kong Institute of Company Secretaries has pointed out, the new Shanghai association was established under the direction and supervision of, and remains dependent upon, the securities authorities in Shanghai. In sharp contrast, the Institute of Company Secretaries in Hong Kong operates as an independent professional organization, and is neither controlled by, nor financially dependent on, the SAR government authorities (Leung 2003:17).

\section{Notes}

Similar agreements also exist between the CSRC and the stock exchanges of New York, London and Singapore.

2 See also the Measures for the Administration of Disclosure of Shareholder Equity Changes of Listed Companies (CSRC, promulgated 28 September 2002, effective 1 December 2002).

3 The catalogue, which took effect on 1 April 2002, excludes foreign firms from taking large or controlling stakes in strategic industries such as military facilities, airlines and civil airport construction and airport operation firms (see Sito 2002, Bei 2002a and Baker 2002).

4 Circular (dated 4 July 2003) issued by the company to all holders of H-shares and received by the writer as a holder of such shares later the same month. See also Notice of Extraordinary General Meeting issued by Tsingtao Brewery Company and dated 26 June 2003.

5 See Article 49, Article 50 and Article 70. 
6 Zhang Zhenduo was deputy manager of the Shandong Branch of the Bank of China, and Yu Fuzhong was General Manager of the Industrial and Commercial Bank of China, Qingdao Branch.

7 'Major related party transactions' are defined as any transaction that the listed company intends to conclude with a related party the total value of which exceeds RMB 3 million or 5 per cent of the company's net assets as recently audited. Independent Directors are specifically vested with the ability to engage the services of an intermediary agency to produce an independent financial advisory report upon which the independent director can base his or her judgement.

8 According to one executive search firm, Bo Le Associates, the average salaries of senior managers in Beijing and Shanghai are still lower than those in Hong Kong, but the gap is narrowing rapidly, and China is becoming an increasingly attractive destination for managerial talent, causing a brain drain from other Asian business centres (Shih 2003).

9 According to the National Bureau of Statistics, there was in the second half of 2003 only one Chinese MBA graduate for every 22 foreign-invested companies, and one Chinese master's degree holder for every 1.5 foreign-invested firms (Shih 2003). 


\title{
5 Foreign banks - market entry and foreign investment
}

\author{
On Kit Tam*
}

\subsection{Introduction}

This chapter analyses the key issues affecting foreign market entry into China's banking sector with particular references to the Chinese government's aim to promote economic development in the country's western region. It argues that a more rapid process of liberalization for market entry by foreign banks will contribute to developing the region. It examines how entry of foreign banks in the country's western region can impact positively on the inflows of foreign direct investment into the region while injecting a much needed impetus for transforming the financial sector through raising the level of competition and transfer of skills and technology.

A well functioning infrastructure for banking and capital markets is critical to a country's economic growth and is pertinent to foreign investment decisions. The financial services sector in the western region clearly lags behind that of the more prosperous eastern coastal region, which in turn is yet to develop into a mature and globally competitive one. Given China's current economic and financial development, the financial sector can play a critical role in creating an attractive investment environment, and allowing a high level of foreign participation in the banking sector in the western region can be a cost-effective means to achieve better outcomes in attracting FDI inflows for the development of the region.

The chapter is organized as follows. Section 5.2 examines the performance of China's banking sector in terms of its role in creating an attractive investment environment for foreign investors and the impacts that foreign bank entry may bring. Section 5.3 identifies and discusses the key barriers to entry and how they could be addressed for a more accelerated pace of liberalization. Some conclusions are given in Section 5.4. 


\subsection{The banking sector in China and the benefits of foreign market entry}

\subsubsection{The financial environment}

In China's economic reform environment, where the building of market institutions is still a work in progress, the efficacy of financial system development is inseparable from progress in other key areas including reforms in SOEs, public finance and the legal system, and regulatory regimes governing market entry and operation of both domestic and foreign participants. In both direct finance and financial intermediation, the effectiveness of the statedominated financial system in China is unsatisfactory, and this sector has lagged behind others in attaining a free and competitive market environment. ${ }^{1}$ The pace and extent of financial development in the western region are well behind those in the coastal region. Redressing this imbalance will be an important factor in building a more favourable business environment for attracting FDI inflows to the western region.

Because finance is highly fungible and liquid, reform of the basic structure of a country's financial system cannot be differentiated by local geography and must be carried out at the national level. It is therefore unproductive to try to institute special treatments for financial transactions for any particular region in the hope of attracting FDI. Otherwise, the outcome will invariably be more market distortions and opportunities for rent-seeking activities amid regional protectionism within the country.

However, to build up a relatively attractive foreign investment environment in the western region, there is a case for accelerating the country's timetable for liberalization of FDI inflows into the region. Particularly in the important banking sector, measures to relax certain regulatory preconditions for setting up business or branches in the region could provide a much needed impetus for FDI utilization without compromising prudential requirements. Such policy measures make no claims on public finance and do not create market distortions.

As the Chinese government has long recognized during the country's economic reform progress, some policy measures incur direct and indirect costs to the government and to some sections of society that are affected by the resource reallocation and wealth redistribution from various reform measures. The more conspicuous costs for the government include subsidies, rebates, loss of tax revenue through various concession schemes, and budget expenditures on the provision of resources to support a range of activities and projects.

Another major but less apparent cost is the financing by the Chinese government of measures to reduce the state banking system's non-performing loans. Unlike the opening up of the manufacturing sector, the opening of the banking and financial sector does not need massive government subsidies and concessions. On the contrary, it can be expected to produce substantial positive externalities for the economy. The expected competitive pressure brought onto domestic banks is certainly real but, based on experiences both in China and elsewhere, the overall benefits can be significant. 


\section{On Kit Tam}

First, the presence of foreign-invested financial institutions, especially foreign bank branches, can directly catalyze additional foreign direct investment. Foreign companies collect market intelligence, conduct research, and perform due diligence in making investment decisions. To carry out all those critical steps, foreign investors need, and prefer to have, the range and quality of services and service providers that they are accustomed to in their home country and other top foreign investment destinations (including coastal China). Therefore, having foreign banks on the ground that can operate under commercial best practice and business scope will clearly make the investment environment in western China more attractive to foreign investors. In addition to providing banking services that are compatible with the foreign investors' international activities, such foreign banks will also be able to provide much needed advice and local knowledge of the business environment.

Second, it is well established that the development of the financial sector helps push overall economic development and makes the general business environment better (Litan et al. 2001). As the Chinese government has indeed acknowledged, the entry of foreign financial institutions (particularly foreign banks) provides an important stimulus to raising the technology, management skills and quality of services of the domestic banking system.

The Chinese government's policy of gradual opening of the financial sector has clearly been beneficial for the financial and economic development of coastal China and there are even more reasons and greater urgency for accelerating the process of financial development for the country's western region. In addition to the direct catalytic benefits in attracting FDI, foreign bank entry will have a further and probably more profound benefit in the competitive spur this will provide to China's state-owned and joint stock banks.

Improvements in practices and service in these banks as a result of competitive pressure from foreign banks will benefit all enterprises, including local private companies and SOEs. When foreign banks entry is accompanied by other financial institutions (such as insurance companies, mortgage banks, car finance companies and fund management companies), an enhanced economic environment will be created. The usual arguments that have been put forward for opening up the banking sector in any country (including China) are certainly pertinent and more urgent for this region because of the slower progress in its financial development to date.

The challenge to the Chinese government does not lie in bestowing the western region with special concessions and subsidies tied to financial flows associated with FDI activities in that region. It is more productive to focus on creating more competition in, and raising the sophistication of, the key player in the financial services sector - the banking institutions. To achieve that goal, the quantity and the scope of banking institutions in the region need to be expanded by expediting the liberalization process to allow qualified foreign and private investors to establish banks and non-bank financial institutions. Apart from the positive competition and demonstration effects, this should also enhance credit availability in Chinese currency and improve project bankability for FDI activities. 


\subsection{Challenges for China's banking system}

China's predominantly state-owned banking system has been made to serve the state industrial sector, resulting in a whole range of attendant problems that are well known (Tam 1995, Lardy 1998, Xie 2003). It is not the purpose of this study to examine the whole issue of the restructuring and development of China's banking system. This chapter aims to investigate why the opening up of the banking sector in the western region is important in enhancing the foreign investment environment. The reform of the country's banking system has lagged behind other sectors of the Chinese economy. The productivity of the state banks is low and their efficiency in transforming savings into productive investment has been poor. Chinese banks, whether they are state owned or owned by shareholders, are heavily taxed and exploited for fiscal revenue by the state (Langlois 2001).

More important from the perspective of foreign investment is the acknowledged fact that most Chinese banks' credit management system and mode of operation still lack effectiveness and adaptability to meeting the changing and expanding needs for international trade and investment (People's Daily, 9 July 2002). For instance, credit rating of enterprises is geared for industrial manufacturers and does not take into account the characteristics of enterprises that engage in foreign trade and investment. As in many other areas involving government approval, bank loan approval processes tend to be unreasonably long and complicated.

One of the most conspicuous features of the malaise of China's banking system is the huge proportion of non-performing loans (NPLs) in the four major state banks. While the official average figure of NPLs for the four state banks was about 26 per cent as of 2001, estimates by various observers can range up to 60 per cent of the banks' total outstanding loans. Regardless of the true extent of the NPLs, it is commonly agreed that the problem is serious (Lardy 1998, Ma and Fung 2002). The banking sector's preoccupation with serving the stateowned sector has also meant that it has not provided effective services to the fledgling private sector (Tam 2004), the healthy development of which is a critical condition for building an attractive investment environment for sustainable inflow of productive FDI.

It is interesting to note that the NPL situation may exert indirect influence on the financial sector in the western region. The high level of NPLs and the recently introduced more stringent and direct personal responsibility for bank credit officers has unwittingly led to a certain degree of reluctance by state banks to extend credit to avoid managing risks. This situation clearly poses a problem for the economic development in the western region, particularly for the development of the increasingly important private sector and the creation of an attractive investment environment.

While there is no comprehensive documentation on the catalyst impact of foreign banks in attracting FDI to host countries, survey and interview data collected by the ADB project team clearly indicate that foreign investors do have a strong preference for the presence of foreign banks to provide them with the kind and quality of services they require. Because Chinese banks are allowed to 
engage only in traditional banking services, with 70 per cent of their profit coming from interest income (restrictions not unlike the previous Glass-Steagall Act in the United States), they are less likely to be capable of servicing the full range of needs of foreign investors.

In contrast, foreign banks are usually universal banks that can provide a more comprehensive spectrum of services in a global framework. Their branches in China will be part of this international business network and will therefore be better able to service existing foreign investors and help attract new ones. There is nevertheless ample anecdotal evidence from media reports and from foreign banks already in China that foreign banks have played a significant role in facilitating and raising the volume of FDI inflows. ${ }^{2}$

\subsubsection{Banking services for foreign investors}

Interviews ${ }^{3}$ with foreign enterprises already operating in Sichuan provide information at firm level on the extent and nature of problems encountered by foreign companies in obtaining credit finance from the Chinese banking system. They show that an overwhelming majority of foreign investors are dissatisfied with and highly critical of the banking services they get from the Chinese state owned banks. The major complaints are:

- Inadequate banking services that cannot meet demand;

- Difficulty in obtaining loans, with complicated, inflexible and timeconsuming procedures in loan applications;

- Problems with the requirement to obtain a guarantee from an international bank in order to borrow from domestic Chinese banks; and

- Expensive and time consuming process in registering for loan collateral.

Indeed these problems are similar to those faced by private enterprises in China (Tam 2004). Whereas domestic enterprises may resort to various kinds of informal credit markets, foreign-invested enterprises do not usually have this type of choice. The case for creating effective alternatives through the presence of foreign banks is therefore clear and justified.

On the basis of a recent survey of foreign-invested enterprises by a Chinese state bank in Shanghai, a basic set of financial services required by foreign investors are identified (Zhonghua Gongshang Shibao (China Business Times), 30 September 2002):

- Banking facilities that enable electronic enquiries and payment settlements, cross-region money transfers, and domestic letters of credit;

- Internationally accepted forms of credit transactions, and products such as receivables financing and bank overdraft facilities;

- Products for managing exchange rate risks, and facilities for timely and efficient foreign exchange transactions; 
- Servicing the global need of the treasury function of transnational corporations; and

- Advisory and consultancy services on financial as well as policy and regulatory matters.

It appears that the state-owned banks themselves have started to take some note of the issue of providing better services to foreign companies, but some inherent difficulties remain. As noted, Chinese banks are not permitted to engage in other non-traditional banking services such as investment banking and securities, although state-owned conglomerates such as Everbright and CITIC have been given special treatment to cover the whole range of financial services through their subsidiaries.

Thus most Chinese banks will not be able to provide a comprehensive range of financial services. However, in the last two years the People's Bank of China has appeared to be very selectively opening intermediate areas of services in a limited and guarded way (Wu 2003), although there is so far no clear provision for foreign banks. ${ }^{4}$

\subsubsection{Foreign banks' economic and market impacts}

At the general level, foreign ownership of domestic banks in emerging markets is found 'to increase overall financial institution strength in both quantitative and qualitative terms' by way of:

- Providing greater access to capital and liquidity and bolstering balance sheet strength;

- The knowledge, skill, and technology transfer that accompany foreign bank entry and can be expected to contribute to a stronger control and risk management environment;

- More broadly, foreign bank presence in emerging market financial systems is argued to contribute to an improved financial system infrastructure by encouraging higher standards in auditing, accounting and disclosure, credit risk underwriting and reserving, and supervision (Crystal et al. 2001).

At the level of bank operation, the beneficial effects of foreign bank ownership can be gauged by the expected changes in the key factors that constitute a bank's strength. Crystal et al.'s (2001) summary of what is termed the CAMEL Framework for assessing domestic bank strength in the event of foreign bank acquisition may be relevant here, and is presented in Table 5.1. 
68 On Kit Tam

Table 5.1 CAMEL analysis of bank strength

\begin{tabular}{|c|c|c|}
\hline & Components of CAMEL Analysis & $\begin{array}{l}\text { Possible Implications of } \\
\text { Foreign Ownership }\end{array}$ \\
\hline $\begin{array}{l}\text { Capital } \\
\text { Adequacy }\end{array}$ & $\begin{array}{l}\text { Compliance with regulatory } \\
\text { standards; } \\
\text { Adequacy given nature/level of risks, } \\
\text { and future expansion plans; } \\
\text { Quality of bank capital. }\end{array}$ & $\begin{array}{l}\text { Improved access to and } \\
\text { increased diversification of } \\
\text { bank capital, leading to } \\
\text { stronger and more stable } \\
\text { capital levels. }\end{array}$ \\
\hline Asset Quality & $\begin{array}{l}\text { Creditworthiness of bank loans and } \\
\text { investments; } \\
\text { Adequacy of credit policies and } \\
\text { procedures; } \\
\text { Adequacy of loan loss reserve } \\
\text { policies and levels; } \\
\text { Level of impaired assets to capital } \\
\text { and reserves. }\end{array}$ & $\begin{array}{l}\text { Improved credit } \\
\text { underwriting and } \\
\text { administration leading to } \\
\text { lower non-performing loan } \\
\text { levels and higher reserve } \\
\text { coverage of NPLs. }\end{array}$ \\
\hline Management & $\begin{array}{l}\text { Fitness and experience levels; } \\
\text { Adequacy of strategic and operating } \\
\text { plans; } \\
\text { Risk management and control } \\
\text { environment; } \\
\text { Succession planning. }\end{array}$ & $\begin{array}{l}\text { Secondment of management } \\
\text { from head office, coupled } \\
\text { with risk management and } \\
\text { internal control practices } \\
\text { closer to international norms, } \\
\text { leading to better corporate } \\
\text { governance. }\end{array}$ \\
\hline Earnings & $\begin{array}{l}\text { Quantity and quality; } \\
\text { Diversification; } \\
\text { Sensitivity to market risk. }\end{array}$ & $\begin{array}{l}\text { Wider variety of products } \\
\text { and services, stronger } \\
\text { corporate governance, and } \\
\text { potentially lower funding } \\
\text { costs, leading to higher and } \\
\text { more stable bank earnings. }\end{array}$ \\
\hline Liquidity & $\begin{array}{l}\text { Adequacy of asset/liability } \\
\text { management policies and procedures; } \\
\text { Appropriate level of asset and } \\
\text { liability liquidity; } \\
\text { Diversification of funding sources; } \\
\text { Contingent funding plans. }\end{array}$ & $\begin{array}{l}\text { Foreign bank access to } \\
\text { parent bank liquidity and } \\
\text { international funding } \\
\text { markets, in combination with } \\
\text { a higher credit standing of } \\
\text { the parent and more } \\
\text { sophisticated balance sheet } \\
\text { management techniques, } \\
\text { leading to better liquidity } \\
\text { management. }\end{array}$ \\
\hline Note & & \\
\hline
\end{tabular}


Crystal et al.'s (2001) comparative study of foreign and domestic banks in the seven largest economies in South America (Argentina, Brazil, Chile, Colombia, Mexico, Peru and Venezuela) finds that foreign banks have consistently stronger average credit growth, take more aggressive action to deal with asset quality deterioration, and possess the capacity and willingness to sacrifice short-term profitability for longer-term soundness. The findings suggest that foreign ownership may have quite positive implications for financial sector stability, development, and efficiency. The effects given in Table 5.1 primarily refer to a complete or partial change in bank ownership. It may be argued that, a priori, most of these impacts will be strengthened in the case of the establishment of foreign bank branches because the positive effects of full ownership and control will be realized. In the context of China's development this is particularly relevant as foreign banks have so far opted mainly for the creation of a branch as the market entry mode.

From recent experience in countries where the domestic banking sector is under stress, the entry of foreign banks through mergers and acquisition activities has clearly worked to produce positive outcomes. There is now clear empirical evidence to show that, particularly among emerging economies, foreign bank entry has led to improvements in a country's banking system efficiency (Roldos 2002). There is also some evidence to suggest that a greater foreign bank presence contributes to a more stable banking system and less volatility in the availability of credit (Dages et al. 2000; Clarke et al. 2002).

Given the potential problems posed by the high level of NPLs, any policy action and regulatory initiative to encourage such activities in China will have similar benefits. Of no less importance and relevance for the development of China's western region is the positive contributions that foreign bank presence will make to enhancing the attractiveness of the foreign investment environment. In a review of empirical evidence on the role of foreign banks in a large sample of economies, the following positive impacts are found (Poret 2001):

- Based on a study of 21 transition economies, a clear correlation is found between foreign bank participation in a country and various key indicators of banking reform;

- There is evidence that foreign bank entry at various times in Nordic countries, Hungary, Korea, and Mexico has helped countries recover faster from banking crises, partly through the broadening of the capital base of the country's banking and financial sector;

- The benefits from the transfer of financial knowhow and increased efficiency are extensive. For instance, after acquiring the Midland Bank in the United Kingdom, HSBC has successfully brought from Asia a cash-flow method of assessing lending to SMEs; and

- Prudential standards and compliance have been upgraded. Foreign banks are already subject to Basel and other internationally accepted requirements and practices relating to capital adequacy, risk management and information disclosure. Their entry into the domestic market has tended to lift the performance of local banks in these important areas. 


\section{On Kit Tam}

In terms of creating an attractive environment for FDI, the benefits from the entry of foreign banks are not limited to the various static gains discussed above. There are also important dynamic benefits in the form of the evolution of a more efficient, internationally competitive financial sector that provide a basis for the country's long-term economic development in a sustainable way. On the other hand there are also some commonly held beliefs in the possible negative impacts from foreign bank entry:

- The limited ability of local banks to compete with the larger global banks and the consequent adverse impact on their performance;

- Foreign banks concentrate only on the profitable high value-added end of the market, and leave the more risky customers to the less competitive local banks; and

- Foreign bank entry introduces instability to the banking system because of the additional avenues for capital flight.

However, some of these concerns are based on a notion of banks as having certain national strategic importance, and from the perspective of local banks that are usually bestowed with monopolistic profit opportunities from having a bank license as a scarce and administratively allocated resource. In any case, as the empirical evidence noted in the preceding paragraphs has demonstrated, foreign bank entry does not as a rule result in any of those feared negative outcomes. Furthermore, given that foreign banks in China only account for about 2 per cent of the market at present, and are not expected to exceed 15 per cent within the next fifteen years according to estimates by the Citibank Group, the feared market effect on domestic banks is unlikely to be systemically devastating for the sector although with foreign entry individual banks may suffer a decline in their share of a growing but more competitive market.

\subsubsection{The insurance industry experience}

Indeed, the benefits from the competition of foreign life insurance companies in Shanghai in which the life insurance market has seen impressive growth amply demonstrate the positive role that market entry of foreign competitors can play in transforming and lifting the industry's capacity and performance. The city is where most of the foreign insurance companies are initially allowed to start up joint ventures to sell insurance policies (except in the special case of the American company AIG which has been allowed to operate as a wholly foreignowned company up to the present). Shanghai is the base for 8 of the 17 foreign life insurance companies in operation or about to set up business as of 2002, and 7 of the 11 foreign property insurance companies (Caijing 2002). However, on all counts the entry of foreign insurers has directly contributed to a growing and vibrant insurance market in Shanghai and China.

Foreign entry did not decimate the Shanghai insurance market and has not resulted in any instability. On the contrary, the city's insurance premium income 
has continued to grow at an average annual rate of over 30 per cent since the mid-1990s. The total profits of Shanghai's Chinese and foreign-participated insurance companies accounted for 25 per cent of the total profits of the insurance industry of the country in 2003. There is no doubt that Chinese insurance companies have benefited from the presence of foreign entrants and there is much that local companies need to catch up (including business models, management, product development, marketing, financial control and claims administration, and investment systems).

The less obvious but equally important contributions that foreign insurance companies make are to do with establishing benchmarks of professionalism, ethical standards, accountability, and transparency in the conduct of business and the behavior of insurance agents in this emerging industry. Insurance products, whether life or property insurance policies, are a new and unknown commodity for the majority of the Chinese population. The entry of foreign companies with their experience and expertise, and the competitive pressure this exerts on Chinese companies, have helped create an awareness, acceptance and demand for insurance products among an increasing proportion of Chinese consumers. There is no doubt that the kinds of contributions that foreign insurance companies have made to the development of China's insurance industry can similarly be repeated under a more liberal entry environment by foreign bank entry in the western region.

Given the fact that the western region lacks most of the complementary economic fundamentals that provide an attractive FDI environment, there is no alternative but to create a financial infrastructure that should be one of the most market-friendly and efficient in the country in order to better facilitate FDI inflows and to gain a competitive advantage position in attracting foreign investment.

\subsection{Foreign bank entry}

While the case for a stronger and more extensive presence of foreign banks in the western region can be established, it remains the decision of the foreign financial institutions themselves whether they are willing and able to conduct banking business at locations in the western region. Of the total number of foreign bank branches and foreign bank representative offices in China, most are located in cities of the coastal region. In the capital of Sichuan, Chengdu, there were only one foreign bank branch (compared to 45 in Shanghai and 24 in Shenzhen) and seven foreign bank representative offices, and for the whole of the western region there were only three foreign bank branches in 2000 . 


\section{On Kit Tam}

At the time of writing, a foreign bank in China could take one of three forms permitted by Chinese law:

- Solely foreign-funded foreign bank with its headquarters located in China;

- Joint equity bank whereby a foreign financial institution and a Chinese financial institution jointly fund and run the operation in China; or

- Foreign bank branch established in China by a foreign bank.

\subsubsection{Entry mode}

In China, establishing a foreign bank branch has been the most common entry mode. Because the establishment of bank branches imposes various legal and financial obligations on the parent bank in the home country, this may have provided a degree of comfort to the Chinese government, particularly in the early days of the open-door policy when the system of supervision and regulation was being developed from scratch. From the perspective of the Chinese monetary authorities, the tradeoff is that a foreign bank branch is part of the parent bank which is a foreign legal entity subject to the supervision and regulations of the home country's monetary authorities (although China does nonetheless impose a range of prudential requirements of its own on foreign bank branches). On the other hand, there may be some attraction for foreign financial institutions in opting for the bank branch mode because of the high level of control and organizational integration with the parent bank.

While many foreign financial institutions do have strategic ambitions to enter and develop the China market, the Chinese government has been very cautious in the opening up process. The aim to protect the domestic banking industry against foreign competition has clearly played a part in that approach. Under its WTO membership commitments, China has undertaken the gradual process of phasing in the removal of restrictions in respect of conducting Chinese currency business and the geographical location of businesses (see Table 5.2).

However, even as these types of entry restrictions are being dismantled, there remains a range of barriers (some of which may not necessarily be based on prudential considerations) that serve to constrain the capacity of foreign banks to expand their operations in China, and may even deter foreign bank entry. Of course as in the general case of the well understood area of non-tariff barriers to international trade in the literature, it is not unthinkable that certain prudential requirements can be unintentionally or deliberately used as barriers to foreign entry into the market. Table 5.3 summarizes the basic requirements for establishing and operating the three forms of foreign banking institutions in China.

On the basis of the initial set of regulations governing the entry of foreign banks and finance companies (Regulations on the Administration of Foreign Invested Financial Institutions in the People's Republic of China, 25 February 1994), the Chinese government has updated and provided more details in a revised set that came into force in February 2002 (Stipulations on the Enforcement of the Regulations on the Administration of Foreign Invested 
Financial Institutions in the People's Republic of China). Having experienced a period of quite chaotic growth of non-bank financial institutions in the early 1990s and the ever-present systemic threat of the NPL problem with the stateowned banks, the Chinese monetary authorities have taken a very cautious approach to foreign financial institutions entering the Chinese market. The capital and asset requirements for a foreign bank to establish business in China are set at relatively high levels which will vary according to the extent of the foreign bank's business scope in foreign currency and RMB.

For the most common mode of foreign bank entry, via the establishment of a bank branch, the capital requirement to conduct all the permitted scope of foreign currency business is for the parent company to allocate to the branch an amount of non-recallable freely convertible currencies equivalent to at least RMB200 million (US\$24 million) (Table 5.3). If the foreign bank branch were to conduct the complete permitted business scope of RMB business in addition to full foreign currency business, then the amount would rise to RMB600 million (US\$72 million) (People's Bank of China 2002, Article 36).

Table 5.2 China's WTO commitment to the opening of its banking system, 2002

\begin{tabular}{|c|c|c|c|}
\hline \multirow[t]{2}{*}{ Timetable } & \multirow{2}{*}{$\begin{array}{l}\text { Foreign currency } \\
\text { business }\end{array}$} & \multicolumn{2}{|c|}{ RMB local currency business } \\
\hline & & Customers & Location \\
\hline $\begin{array}{l}\text { Upon entry to } \\
\text { WTO } \\
\text { (December } \\
\text { 2001) }\end{array}$ & $\begin{array}{l}\text { Chinese enterprises } \\
\text { and individuals (i.e. } \\
\text { all restrictions on } \\
\text { customers removed) }\end{array}$ & $\begin{array}{l}\text { Foreign-invested } \\
\text { enterprises, } \\
\text { foreign residents }\end{array}$ & $\begin{array}{l}\text { Shanghai, Shenzhen, } \\
\text { Tianjin, Dalian }\end{array}$ \\
\hline $\begin{array}{l}1 \text { December } \\
2002\end{array}$ & as above & as above & $\begin{array}{l}\text { Guangzhou, Zhuhai, } \\
\text { Qingdao, Nanjing, } \\
\text { Wuhan }\end{array}$ \\
\hline $\begin{array}{l}\text { Within } 2 \text { years } \\
\text { of WTO } \\
\text { membership }\end{array}$ & as above & $\begin{array}{l}\text { Chinese } \\
\text { enterprises }\end{array}$ & $\begin{array}{l}\text { Jinan, Fuzhou, } \\
\text { Chengdu, Chongqing }\end{array}$ \\
\hline $\begin{array}{l}\text { Within } 3 \text { years } \\
\text { of WTO } \\
\text { membership }\end{array}$ & as above & as above & $\begin{array}{l}\text { Kunming, Beijing, } \\
\text { Xiamen }\end{array}$ \\
\hline $\begin{array}{l}\text { Within } 4 \text { years } \\
\text { of WTO } \\
\text { membership }\end{array}$ & as above & as above & $\begin{array}{l}\text { Shantou, Ningbo, } \\
\text { Shenyang, Xi'an }\end{array}$ \\
\hline $\begin{array}{l}\text { Within } 5 \text { years } \\
\text { of WTO } \\
\text { membership }\end{array}$ & as above & $\begin{array}{l}\text { All customers in } \\
\text { China }\end{array}$ & $\begin{array}{l}\text { Location restrictions } \\
\text { terminated }\end{array}$ \\
\hline
\end{tabular}

Notes:

To conduct Renminbi business, a foreign-funded financial institution must satisfy the following requirements:

- it must have operated in China for at least three years prior to the application;

- it must have been making profits for the two consecutive years prior to the application; and

- it must meet other prudential requirements prescribed by the People's Bank of China. 


\section{On Kit Tam}

Some foreign banks regard this requirement as unnecessarily excessive and acting as a deterrent to expanding their operation in China, particularly into regions where business needs to be gradually built up before returning a profit. Because bank branches are an integral part of the parent organization, a high level of capital requirement is therefore considered to be superfluous. Compared with domestic Chinese banks, the initial capital cost of funding one foreign bank branch operation is therefore not insignificant, even though most major international banks will not be unduly affected in their market entry plan. As discussed earlier, a foreign bank must also satisfy additional conditions of three years of operation and two consecutive years of profitability before being allowed to conduct RMB business. Taken together, these constitute in practice extra costs and another impediment that deters and slows foreign bank entry.

Table 5.3 Regulation of foreign banks in China - basic elements

\section{Establishment of Business}

Capital

Requirements
Minimum registered capital:

Solely foreign-funded bank \& joint-equity bank

Freely convertible currencies equivalent to RMB300 million yuan (for partial services in foreign currency business with foreign-invested enterprises and foreign individuals)

(for complete services in foreign currency business with foreigninvested enterprises and foreign individuals, the minimum moves up to RMB400 million)

\section{Operating capital:}

\section{Foreign bank branch}

Non-recallable allocation from head office of freely convertible currencies equivalent of no less than RMB100 million yuan (for partial services in foreign currency business with foreigninvested enterprises and foreign individuals)

(for complete services in foreign currency business with foreigninvested enterprises and foreign individuals, the minimum moves up to RMB200 million)

Representative Office

Assets of Applicant
Minimum period of maintaining a representative office in China Solely foreign-funded bank, joint-equity bank and foreign branch

At least two years

\author{
Minimum amount of total assets of the foreign financial institution \\ applying for license in China \\ Solely foreign-funded bank \& joint-equity bank \\ US $\$ 10$ billion \\ Foreign bank branch \\ US $\$ 20$ billion, and a capital adequacy ratio of at least 8 per cent
}




\begin{tabular}{|c|c|}
\hline Business $\mathbf{S}$ & \\
\hline \multirow{2}{*}{$\begin{array}{l}\text { Permitted } \\
\text { Scope }\end{array}$} & Identical for all three types of foreign bank \\
\hline & $\begin{array}{l}\text { Deposit taking, lending, acceptance and discounting of } \\
\text { negotiable instruments, trading of government and financial } \\
\text { bonds, trading of foreign currency securities other than stocks, } \\
\text { letters of credit and guarantee, domestic and foreign settlement, } \\
\text { trading of foreign exchange and acting as an agent, exchange of } \\
\text { foreign currencies, inter-bank lending, bank card business, safe } \\
\text { deposit boxes, credit and financial standing investigation and } \\
\text { related consultancy, other businesses approved by the People's } \\
\text { Bank of China (PBC) }\end{array}$ \\
\hline
\end{tabular}

\section{Supervision and Regulations}

Interest Rates Solely foreign-funded bank, joint-equity bank and foreign branch:

Interest rates of deposit and loans, and service fees determined by banks in accordance with relevant provisions of PBC

\section{Required Reserves}

Operating Capital

Capital
Adequacy
Ratio

Domestic Source of Deposits
Solely foreign-funded bank, joint-equity bank and foreign branch:

Must deposit with $\mathrm{PBC}$ the required ratio of reserves determined by the PBC

Foreign bank branch:

30 per cent of the operating capital must be maintained in the form of interest-bearing assets as prescribed by $\mathrm{PBC}$, including deposits with banks designated by PBC

Solely foreign-funded bank and joint-equity bank:

Not less than 8 per cent

Solely foreign-funded bank, joint-equity bank and foreign branch:

The maximum of deposits from within China cannot exceed 40 per cent of total assets

Source: Regulations on the Administration of Foreign Invested Financial Institutions in the People's Republic of China, 25 February 1994; Stipulations on the Enforcement of the Regulations on the Administration of Foreign Invested Financial Institutions in the People's Republic of China, 29 January 2002.

However, almost without exception, all the foreign banks interviewed by this author $^{5}$ expressed greatest concern over the 40 per cent limit on the amount of a foreign bank's RMB liabilities that can be obtained through inter-bank lending 


\section{On Kit Tam}

from Chinese banks. At the end of 2001, 33 foreign banking institutions (out of a total of 158) were permitted to conduct RMB business with foreign-invested enterprises and foreign residents. Owing to the absence of a branch network, their ability to attract RMB deposits is limited. It is estimated that 50 to 80 per cent of their RMB funds were obtained through inter-bank lending from Chinese banks (Guoji Jinrongbao, 24 July 2002). This restriction on sources of RMB funds represents a serious barrier to foreign banks in their business development and is probably construed as a protective measure against foreign competition.

As Table 5.3 indicates, all three forms of foreign banks are required to have reserves with the Chinese central bank. For a foreign bank branch, 30 per cent of the operating capital must also be maintained in the form of interest-bearing assets as prescribed by PBC, including deposits with banks designated by PBC. These requirements, particularly the last, impose some constraints on the ability of the foreign bank branch to conduct its business as it sees fit. In this context, the more serious concern expressed by foreign banks in China is the onerous approval processes imposed on the business of providing foreign currency credit to enterprises for which each loan must have given pre-approval and approval by the Chinese monetary authorities. The introduction of any financial product is in fact subject to government approval. Thus, foreign banks face constraints in the pricing, quantity, types of products, and scope of business that they can carry out in China. The demand for a more level playing field is very evident among foreign banks in China.

\subsubsection{Impediments to expanding foreign bank branch networks}

For those foreign banks already operating in China, the objective of expanding their business through additional branches faces some significant obstacles. As Tables 5.4 and 5.5 show, domestic Chinese shareholding banks have much more lenient regulatory conditions for gaining approval to create new bank branches than foreign banks. Chinese banks can be granted permission to add new branches even though their basic financials cannot usually match those of the foreign banks in China. More importantly, foreign banks are in effect restricted to a maximum of one new branch per year, while Chinese shareholding banks can have up to four in the western region and three in the rest of the country.

This one branch per year barrier is viewed by foreign banks as one of the most severe constraints upon their business development in China. It is relevant to note that while the parent company of foreign bank branches is required to have at least US $\$ 20$ billion in assets, only 4 of the 11 Chinese shareholding banks had reached that size in 2001 (Table 5.6). In fact most foreign banks currently in China (such as Bank of America, HSBC and Citibank) are much bigger than the minimum size required. 
Table 5.4 Conditions for foreign banks to add a new branch

\section{Foreign bank branch}

(1) Representative office for two years.

(2) Minimum amount of total assets of the foreign financial institution applying for a new branch should be US $\$ 20$ billion.

(3) Existing branch in China should have good business performance, and should have no record of major activities that are contrary to the law and regulations.

(4) Application for an additional branch can only be made one year after the last approval by PBC for establishing a branch (i.e. maximum of one new branch per year).

Solely foreign-funded bank and foreign joint-equity bank

(1) Operation in China over three years; profits in the last two consecutive years.

(2) Capital adequacy ratio not lower than 8 per cent.

(3) Application for an additional branch can only be made one year after the last approval by PBC for establishing a branch.

(4) For each additional branch, applicant must pay no less than 100 million RMB equivalent fully convertible currency as its operating capital; the total accumulated amount of payments for operating capital for a foreign bank's branches (including any planned additional one) cannot exceed 60 per cent of the registered capital of the bank in China).

(5) Other prudential requirements prescribed by the PBC.

Source: Stipulations on the Enforcement of the Regulations on the Administration of Foreign Invested Financial Institutions in the People's Republic of China, Article 15.

Table 5.5 Selected requirements for Chinese shareholding banks to open new branches

(1) In general the number of new branches per year for each applicant bank should be no more than 3; for branches in the western region, the limit could be raised to 4 .

(2) Applicant bank should in general reach the 8 per cent capital adequacy ratio. For those banks under 4 per cent, new branches should be restricted.

(3) Applicant bank should have an NPL ratio of less than 15 per cent. For those with a ratio over 15 per cent, if the ratio is declining, considerations along with other factors can be taken into account.

Source: Yinfa [2002] Number 244 - Notice by the People's Bank of China on Questions Concerning the Adjustment of Investigation Approval Systems for the Establishment of New Branches by Shareholding Banks.

Hence if the same prudential consideration based on bank size being an indication of strength is applied, the case for limiting new foreign bank branches is weak, particularly when each foreign bank branch will still be subject to the 


\section{On Kit Tam}

usual capital and prudential conditions before it can be established. And if Chinese banks are given the incentive to expand into the western region by being allowed one more branch per year, there is no reason why foreign bank entry into the western region should not be encouraged by similar measures. For instance, the Chinese government could quite easily relax the one new branch per year rule for foreign banks by simply excluding the application of this rule to any new branch to be established in the western region.

The requirement that a foreign bank must have made a profit for two consecutive years before it can apply to set up a new branch presents a real problem for many foreign banks in China. It is common knowledge that new bank entrants do not normally generate positive returns during the early years of operation in a new market. That is in fact why foreign financial institutions often have to justify their business development and entry into China as a long-term strategic move. On the basis of interviews with foreign bank representatives in China, this is one of the major concerns and is seen as an unnecessary deterrent to the development of foreign banking networks in the country. After all, the financial parameters of a branch operation are consolidated into the parent banks. Ultimately it is the bank which should determine whether it is commercially advantageous to expand its branch network if genuine prudential requirements are met. The regulator should have no role in deciding what is essentially a commercial decision.

Table 5.6 Chinese shareholding banks, total assets (end of 2000)

\begin{tabular}{lc}
\hline & US\$ billion \\
\hline Bank of Communications & 79 \\
CITIC Industrial Bank & 29 \\
China Merchants Bank & 27 \\
China Everbright Bank & 26 \\
Guangdong Development Bank & 19 \\
Shanghai Pudong Development Bank & 16 \\
Huaxia Bank & 12 \\
Fujian Industrial Bank & 11 \\
China Minsheng Bank & 9 \\
Shenzhen Development Bank & 8 \\
Yantai Home Savings Bank & 2 \\
\hline
\end{tabular}

Source: Almanac of China's Finance and Banking 2001. 
Faced with these obstacles, some foreign banks have started to seek alternative routes to participation in China's banking market by taking strategic minority equity stakes in non-state Chinese banks. For instance, Canadian Bank of Nova Scotia, together with IFC, is buying a 12.4 and 12.5 stake respectively in Xi' an City Commercial Bank; HSBC acquired an 8 per cent stake in the Bank of Shanghai; and Citibank is buying a 5 per cent stake from a state-owned shareholder of the Shanghai Pudong Development Bank.

There are several reasons for foreign banks to be taking an interest in this approach to entering the China market. These may include gaining: experience in serving the domestic market; an immediate presence of some kind through a national branch network; the potential to better access RMB funds; and the opportunities to utilize the strategic link with the Chinese bank to develop profitable financial services such as credit cards. For the domestic Chinese banks, it provides an opportunity to strengthen their capital base and gain knowledge in management, marketing and product development. However, this approach is not without problems.

First, the minority stake may not afford the foreign banks much control or influence over the Chinese bank to allow it to utilize fully its firm-specific advantages to produce better performance and the desired benefits. More important for the foreign investors is the Chinese Central Bank's threshold of 25 per cent of foreign equity in a Chinese bank. That is, if foreign equity exceeds 25 per cent, the Chinese bank will become a joint-equity foreign bank which must operate under regulations governing foreign financial institutions, and that would mean that the privileges and business scope enjoyed by a Chinese bank would disappear. As a result, a major aim for investing in the Chinese bank would be defeated.

In order to attract FDI to the banking sector in China's western region, a relaxation of this threshold to a higher level (perhaps up to 49 per cent) for foreign banks investing in commercial city banks in the region could provide a considerable impetus to enhance the investment environment. In this context, it is relevant to note the recently reported proposal by the publicly listed Shenzhen Development Bank to sell a total of 20 per cent majority stake (held by four companies owned by the Shenzhen City Government) to a private US equity fund, NewBridge Capital Group. There will be positive implications for the opening of China's financial system should Chinese government approval be given to the proposal. Approval would mean that it is possible to acquire a controlling interest without changing the domestic status of a Chinese bank (a 20 per cent stake in Shenzhen Development will make NewBridge the largest shareholder). Perhaps no less significant is the fact that NewBridge is not even a bank. There is therefore no reason why this new direction for Shenzhen cannot be employed for the development of the western region.

In summary, foreign banks clearly continue to face significant barriers in expanding their business in the China market for reasons that may be justified from the perspective of the government. However, compared with the more developed economic and financial system in China's eastern region, foreign banks will find (and have indeed found) it difficult to consider expanding into the western region on both commercial and regulatory grounds. To make foreign 


\section{On Kit Tam}

bank entry into the western region a viable and attractive proposition, it is necessary to speed up the gradual process of foreign market entry and to remove some of the major obstacles for foreign banks expanding into this economically less developed and less open part of China.

\subsection{Conclusion}

China has certainly benefited from special policy measures designed to attract foreign investment, particularly in its early stage of development. If the government is serious about creating a more vibrant and efficient banking sector to bring about a more attractive foreign investment to serve the objective of developing the western region, the need to devise a policy package that removes entry barriers for foreign banks in the western region is critical. It is relevant to note that the conditions governing the creation of new branches by China's shareholding banks appear far more lenient (see Table 5.5). At present only major foreign banks with a much larger scale of operation than any of China's shareholding banks are allowed market entry into China. On the basis of the experience of foreign bank entry in other economies discussed earlier, the relaxation of restrictions for these foreign banks to expand into the western region will not pose a threat to the banking system.

Because the western region is already less developed, with higher transactions costs across most economic activities for foreign investors, all the barriers discussed above can be expected to have a pronounced adverse impact on foreign bank entry into the region. Policy considerations should therefore aim at addressing these issues to attract a substantive inflow of FDI into the region's banking sector so as to enhance financial development and to help catalyze FDI inflows in all other sectors of the economy.

Given the current state of economic and financial development in the western region, it is realistic to concentrate efforts on developing selected key cities (such as Chengdu, Chongqing and $\mathrm{Xi}$ 'an) as effective financial centers for the western region. Simple and effective administrative mechanisms for better coordination, support and monitoring for this development among the China Banking Regulatory Commission, People's Bank of China, the State Administration of Foreign Exchange, China Insurance Regulatory Commission, China Securities Regulatory Commission, Ministry of Finance, and other relevant prudential and supervisory bodies should be set up with a view to facilitating institution and capacity building in the financial services sector in the western region.

Specific policy measures may include the immediate granting of a number of new banking licenses (valid for offering full RMB business), ahead of China's WTO commitments, for foreign investors to establish wholly owned branches or joint ventures to conduct both foreign-currency and Chinese-currency business in the region's selected cities. Without compromising prudential requirements, some of the current barriers and certain preconditions for establishing new branches by foreign banks already operating in China should also be relaxed for the western region. 
Foreign banks that are already in China can be encouraged to expand their branch network into the western region by dropping the 'one branch per year' restriction and the precondition of two consecutive years of profit. The 40 per cent inter-bank RMB-currency borrowing limit on foreign banks in the western region should be lifted to a higher level (to be determined after consultation with foreign banks). Alternatively, foreign banks in the western region should be allowed to expand their sources of RMB funds by issuing instruments such as certificates of deposit. The threshold for foreign equity investment in a Chinese bank located in the western region could be raised from the current 25 per cent to a higher level of, say, 49 per cent to encourage more foreign participation.

As part of the financial development process, eligible domestic Chinese individuals and enterprises should also be allowed to invest to establish new banks or invest in joint ventures with foreign banks as partners. The aim is to provide an impetus to raise the level of competition and quality in banking services to enhance the investment environment. The process of foreign bank entry into the Chinese market has already begun, and it is important that the economic benefits that come with this are well utilized and managed, and that a more competitive and attractive foreign investment environment be created for foreign banks to help develop China's western region.

\section{Notes}

* This chapter is based primarily on parts of a commissioned report written by the author on the role of the financial and professional service sectors in creating an attractive investment environment for an Asian Development Bank technical assistance project on 'Attracting FDI to Western China (TA No 3806 -PRC)'. The report is used with permission from the Asian Development Bank. For information related to development in Asia and the Pacific, see www.adb.org. I am grateful to Song Ping for her contribution to the collection of survey data of financial institutions in Sichuan for the study, and for her comments on an earlier version of the report. Helpful comments on an earlier draft of the commissioned report by Davin MacKenzie are also gratefully acknowledged. Views expressed in this chapter represent only the author's.

1 For a discussion of China's recent financial development see for example Zhou (2003), Lu and Dai (2002), Lardy (1998).

2 For instance, foreign bank branches in Jiangsu Province are reported to have started cooperating in recent times with Chinese banks that have sought foreign capital to finance industrial and infrastructure projects (Jingji Ribao [Economic News], 2 September 2002).

3 Interview data relating to the financial services sector was collected by this author and Yang Ping. General foreign investors survey and interview data were provided by Zhang Sanli, a local consultant member of the ADB project.

4 According to People's Bank of China's Interim Regulations of Intermediate Business of Commercial Banks 4 July 2001 intermediate business is defined as business from non-interest income outside of the bank's balance sheet of assets and liabilities. Some of these businesses will require only notification to the central bank for services (such as remittances, agency for the issuance, underwriting and redemption of government bonds, salary payment, or collection of public utilities charges) to be offered. Other intermediate businesses require approval by the central bank before they may be offered (such as redemption of commercial papers, issuing of letters of credit, loan guarantee, financial derivatives, trust deposits, and insurance agency).

5 Bank of America, HSBC, Commonwealth Bank of Australia, Australian New Zealand Banking Group. 


\title{
6 Accounting for intangible assets and the relevance of financial statements in developed and emerging capital markets: Australia and China
}

\author{
Jayne M. Godfrey and Wei Lu
}

\subsection{Introduction}

Research indicates that there are differences in the ways that investors in developed countries such as Australia, the US and the UK value the intangible assets reported in firms' financial statements (Barth and Clinch 1996, Barth 2000, Lev and Zarowin 1999). Using the Australian institutional setting, research has particularly investigated the relevance of capitalized goodwill, and capitalized research and development to equity valuation (Abrahams and Sidhu 1998, Godfrey and Koh 2001). However, research has not yet investigated the association between the market value of firms in developing countries and their book values of intangible assets. Since the promulgation of China's first western-style accounting standard Chinese Accounting Standard for Enterprises in 1992, accounting standards and regulations issued by the Chinese government have become increasingly internationally compatible. This gives rise to a unique research opportunity to examine the economic relevance of accounting in the emerging economy of China. Using large samples of. Australian and Chinese companies, this chapter investigates the relevance of capitalized intangible assets to equity valuation. In particular, it investigates whether variations in the book values of individual capitalized intangible assets or the aggregate book values of capitalized intangible assets explain variations in the market value of equity for Australian and Chinese firms.

The chapter examines how combinations of accounting practices and different institutional settings can affect the relevance of accounting for intangible assets, particularly goodwill, to equity valuation. It first documents differences between how firms in Australia and China account for intangible assets. It then examines the association, for both countries, between the market value of firms' equity and the book values of their assets and liabilities, with particular emphasis on the association with book values of various types of capitalized intangible assets. 
The study reported in this chapter has two objectives:

- It examines the differences between the rules for writing off, capitalizing and amortizing a variety of intangibles based on Australian and Chinese pronouncements (GAAP).

- It tests the value relevance of the different national practices within their jurisdictions.

While other studies have examined the value relevance of accounting measures in the context of Western countries (for example Barth and Clinch 1996), this chapter brings the issue to the Chinese jurisdiction for two main reasons. First, the Chinese economy has grown rapidly since 1991 and has been ranked by the International Monetary Fund as the second largest economy in the world. It has attracted much foreign investment, and Chinese firms are regarded as bringing high levels of growth options to the investment market; hence they can be expected to have valuable intangibles, both reported and undisclosed. Second, the Chinese stock market has developed dramatically since the early 1990s when China established stock markets in Shanghai and Shenzhen. Indeed, listings increased from eight companies to over 1,200 by the end of 2002 . This capital market growth provides an opportunity to investigate the maturity of the Chinese capital market participants' use of accounting numbers. Third, since the 1980s, China has undertaken a series of reforms to align its accounting system with internationally accepted practices (Aiken et al., 1995). The success of these reforms has been documented and discussed internationally, but it is also widely acknowledged that differences still exist between the existing Chinese accounting framework and the accounting framework adopted by the International Accounting Standards Board.

\subsection{Accounting for intangible assets: a comparison}

Regulating the accounting for intangible assets is arguably the most controversial and difficult area faced by accounting standard-setters worldwide (Choi and Lee 1991, DeMark 2002). The issue is particularly important because of continuing international mergers and acquisitions, and the rapid development of international financial markets (Radebaugh and Gray 2002, Hoegh-Krohn and Knivsfla 2000). In this environment intangible assets, especially goodwill, generally dominate the underlying economic value of assets acquired. Furthermore, reported intangible assets are the embodiment of the economic growth options that give firms their main value. Table 6.1 summarizes the main differences between the current requirements for accounting for intangibles in China and Australia. 
84 Jayne M. Godfrey and Wei Lu

Table 6.1 Summary of current requirements for accounting for intangibles in Australia and China

\begin{tabular}{|c|c|c|}
\hline Issues & $\begin{array}{l}\text { Current AASB Requirement in } \\
\text { Australia }\end{array}$ & Current Requirement in China \\
\hline $\begin{array}{l}\text { Goodwill } \\
\text { acquired in a } \\
\text { business } \\
\text { combination }\end{array}$ & $\begin{array}{l}\text { Goodwill is amortized to income } \\
\text { over a period not to exceed } 20 \\
\text { years. }\end{array}$ & $\begin{array}{l}\text { Goodwill should be recognized as } \\
\text { an asset. The cost of goodwill } \\
\text { should be amortized evenly over } \\
\text { its expected useful life. } \\
\text { Impairment review should be } \\
\text { conducted periodically, but at least } \\
\text { once at the end of each year. }\end{array}$ \\
\hline $\begin{array}{l}\text { Identifiable } \\
\text { intangibles in a } \\
\text { business } \\
\text { combination }\end{array}$ & $\begin{array}{l}\text { There is currently no standard } \\
\text { specifically governing the issue } \\
\text { since the withdrawal of ED } 49 \\
\text { Accounting for Identifiable } \\
\text { Intangible Assets. AASB } 1021 \\
\text { Depreciation applies to both } \\
\text { tangible and intangible assets. } \\
\text { This standard requires the } \\
\text { depreciable amounts of assets to } \\
\text { be depreciated over their useful } \\
\text { lives in a manner that reflects the } \\
\text { loss or consumption of future } \\
\text { economic benefits to the entity. }\end{array}$ & $\begin{array}{l}\text { Similar to the treatment of } \\
\text { goodwill. }\end{array}$ \\
\hline $\mathrm{R} \& \mathrm{D}$ costs & $\begin{array}{l}\text { Both research and development } \\
\text { costs may be capitalized if } \\
\text { certain criteria are met. }\end{array}$ & $\begin{array}{l}\text { Research and development costs } \\
\text { incurred prior to the legal } \\
\text { application of obtaining the } \\
\text { intangible asset should be } \\
\text { recognized as expenses in the } \\
\text { period in which they are incurred. }\end{array}$ \\
\hline $\begin{array}{l}\text { Internally } \\
\text { generated } \\
\text { brands, } \\
\text { mastheads, } \\
\text { publishing } \\
\text { titles, customer } \\
\text { lists }\end{array}$ & $\begin{array}{l}\text { Currently the AASB has agreed } \\
\text { to expose the IASB requirement } \\
\text { and highlight the implication of } \\
\text { this requirement in the } \\
\text { Australian 'wrap-around'. }\end{array}$ & $\begin{array}{l}\text { Only if assets are obtained by } \\
\text { legal application are they } \\
\text { permitted to be capitalized. The } \\
\text { amount is determined in } \\
\text { accordance with the amount of } \\
\text { expenditure (such as registration } \\
\text { fees and legal fees) incurred for } \\
\text { legal application of obtaining the } \\
\text { asset. }\end{array}$ \\
\hline $\begin{array}{l}\text { Revaluation of } \\
\text { Intangible } \\
\text { Assets }\end{array}$ & $\begin{array}{l}\text { Revaluation of intangibles is not } \\
\text { permitted. }\end{array}$ & $\begin{array}{l}\text { Revaluation of intangibles is not } \\
\text { permitted. }\end{array}$ \\
\hline
\end{tabular}

\subsection{Australia}

The current accounting standards in Australia related to intangibles include AASB 1011 Accounting for Research and Development Costs and AASB 1013 
Accounting for Goodwill. Some of the abstracts issued by the Urgent Issues Group $^{1}$ to provide guidance in the absence of a standard also relate to intangible assets (e.g. UIG Abstract No. 5: Methods of Amortization of Goodwill (withdrawn), UIG Abstract No. 7: Accounting for Non-Current Assets Derecognition of Intangible Assets and Change in the Basis of Measurement of a Class of Assets, UIG Abstract No. 34: Acquisitions and Goodwill - First Time Application of Accounting Standards).

\subsubsection{Goodwill}

In theory, goodwill is the difference between the value of a firm and the sum of the value of its individual assets. It reflects the value of synergies derived from combining assets. Unlike other assets, goodwill incorporates the value of future earnings as they contribute to the valuation of the business as a whole. It is a matter of considerable controversy whether goodwill should be treated as a separate asset for accounting purposes and whether it should be amortized against future earnings since it is not separately identifiable and its value may increase over time rather than diminish. Treatments have varied internationally (Nobes and Norton 1996).

Accounting for Goodwill (AASB 1013) classifies unidentifiable intangible assets into two categories: internally generated goodwill and purchased goodwill. The standard requires purchased goodwill to be capitalized and amortized through earnings using a straight-line method over a period of 5 to 20 years (Australian Accounting Standards Board 1996). If the economic benefits of the purchased goodwill are deemed to have fully expired, the goodwill is to be completely written off through earnings. Capitalization of internally generated goodwill is not permitted.

Australia is currently preparing to adopt a new approach to accounting for goodwill. Under this approach, goodwill will not be amortized systematically. Instead, it will be written off as it is deemed to have been impaired. This means that goodwill may be carried in the accounts at an unamortized amount for several years; alternatively, it may be written off very rapidly, depending upon assessments of the economic circumstances that affect goodwill valuation.

\subsubsection{Identifiable intangible assets}

Generally, rules governing the accounting for identifiable intangible assets are the subject of standards relating to individual types of intangibles. However, there have been some attempts to develop general standards governing the full range of these assets, most notably in Australia and in the International Financial Reporting Standards (IFRS) developed by the International Accounting Standards Board (IASB).

In 1989 the Australian Accounting Research Foundation (AARF) issued an exposure draft, Accounting for Identifiable Intangible Assets (ED 49), dealing with accounting for identifiable intangible assets such as brand names and other related intangibles. ED 49's general proposition was that both purchased and 


\section{Jayne M. Godfrey and Wei Lu}

internally developed intangible assets are to be brought to account (Alfredson 2001). Under ED 49, purchased identifiable intangible assets were recorded at the cost of acquisition and internally generated identifiable intangible assets were recorded either at cost or at the lowest cost at which they could currently be obtained in the normal course of business, as determined by independent valuers. ED 49 required amortization of intangible assets but it nominated no maximum period. Because of the lack of consensus on a number of issues, such as the requirement to amortize all identifiable intangible assets (including brand names), the exposure draft was withdrawn in 1992.

In 1996 the AASB initiated its International Harmonization Project, planning to revise more than 20 Australian Accounting Standards to accord with International Accounting Standards (Collett et al. 2001). In addition, a new accounting standard on intangible assets was to be issued (Parker 1997). The intangibles project was delayed significantly as the board dealt with some highly contentious issues, such as the treatment of brand names during a period when firms were accused of opportunistic overstatement of brand name values, and with the issuance of IAS 38, Intangible Assets in 1998. IAS 38 specifies that the deemed useful life of an intangible asset should not exceed 20 years, and an intangible asset is to be carried at its cost less any accumulated amortization and impairment losses. The standard prohibits the recognition of internally generated brands, mastheads, publishing titles and similar intangibles and permits revaluation of intangibles only where there is an active market. These requirements sparked a highly charged debate on the proper treatment of identifiable intangibles. Most lobbyists strongly opposed Australia's harmonization with IAS 38.

The International Accounting Standards Board's December 2002 proposed amendments to IAS 36 Impairment of Assets and IAS 38 Intangible Assets propose to remove the presumption that the useful life of an intangible asset will always be finite and that the useful life cannot exceed twenty years from the date the asset is available for use. The draft also proposes that an intangible asset with an indefinite useful life should not be amortized and its useful life should be reviewed every year. Proposed amendments to International Accounting Standards, now known as International Financial Reporting Standards (IFRS) will see some assets no longer recognized (such as internally generated brands, mastheads, or publishing lists). This has been extremely controversial in Australia, but it does not affect the accounts for the period of this study.

\subsubsection{Research and development}

In an international context, Australia's regulations tend to be relatively flexible. In some countries, such as the US, capitalization of research and development (R\&D) is not permitted except for computer software development costs. AASB 1011 Accounting for Research and Development Costs states that R\&D shall be charged to earnings when incurred. However, capitalization of these costs is allowed if they are expected beyond any reasonable doubt to be

recoverable. Capitalized $R \& D$ costs must be amortized over future financial 
years to match them with related benefits, beginning with the commercial production of the product.

It is expected that when Australia adopts IFRS from 1 January 2005, companies will not be permitted to recognize intangible assets arising from research (or from the research phase of an internal project). Development costs will be capitalizable only if certain criteria, such as recoverability, are met.

\subsubsection{Brands and other related intangibles}

The treatment of brand names has been particularly contentious since the collapse of companies whose financial statements had reported brand name assets with high values, but whose capitalized brand values did not withstand market forces. In contrast, it has been argued that a motive for some companies capitalizing brands has been to ensure that they are not undervalued by the capital market, especially in a manner that could lead to possible takeover. ${ }^{2}$

Many international mergers and acquisitions involve acquiring famous brand names, trademarks, patents, licenses and other such intangibles. As such, the treatment of brands and other intangibles is inevitably associated with the treatment of goodwill.

Internationally, there is significant variation in the treatment of purchased brand names. In Australia, regulators prefer the assets to be capitalized and amortized separately from goodwill, and in the US under the new accounting standard FASB 141 Business Combinations identifiable intangible assets with indefinite useful lives, including brands, are not to be amortized and measures are reviewed for impairment. Intangible assets with limited useful lives continue to be amortized.

Treatment of internally developed brand names is even more diverse. In Australia the capitalization of home-grown brands is permitted. The recent IASB Exposure Draft amendments to IAS $38^{3}$, which are likely to be adopted in Australia in 2005, stipulate that internally generated brands, mastheads, publishing titles, customer lists and items similar in substance should not be recognized as intangible assets. As with goodwill, this likely change does not affect the period of this study.

\subsubsection{Deferred costs}

Deferred costs include a variety of capitalized expenditures on such things as advertising, customer acquisition commissions that are expected to provide benefits for several years into the future, and future income tax benefits arising because taxes have been paid in advance of their recognition as an expense for financial reporting purposes. Generally, deferred costs fall within the definition of assets in various countries' conceptual frameworks since they are incurred with a view to deriving future economic benefits. With the exception of future income tax benefits, their accounting is not particularly contentious since they are usually written off against earnings only a short number of years after their initial capitalization. 


\subsubsection{Licence costs}

Licence costs are the up-front payments for agreements such as software licences that allow the use and/or sale of particular software. In Australia it has long been accepted practice to value internally generated licences, copyrights, and publishing rights. Under the proposed IASB changes internally generated brands, mastheads, publishing titles, customer lists and items similar in substance are not recognized as intangible assets. The AASB agreed to expose this change and highlight its implications in the Australian environment.

\subsection{China}

In December 1992, Chinese Accounting Standard for Enterprises was formally promulgated by the Ministry of Finance (MOF) in China (MOF 1992). Compared with International Accounting Standards and the standards in Australia, the US, and the UK, this first Chinese accounting standard is more like a conceptual framework than a detailed prescription of how to account for a particular issue (Chen et al. 2001). It is a guideline about how to set accounting standards. Since the promulgation of that first Chinese accounting standard, the Ministry of Finance has endeavoured to set up the new accounting regulation system by issuing specific accounting standards. However, this procedure is more complicated because of the coexistence of the unified accounting systems and accounting standards (Chen et al. 1997). So far, thirty specific accounting standards have been drafted and circulated for public comment. The major criticism of those drafts of accounting standards is that they are not suitable for the Chinese situation because they mainly copy International Accounting Standards and GAAP in the United States.

The Ministry of Finance planned to establish the accounting standards system in three years, with 32 specific standards in 1993 (Aiken et al. 1995). However, so far only 13 specific standards have been formally promulgated. They are: Accounting for Changes of Accounting Policies and Estimations and Mistakes; Accounting for Revenues; Accounting for Investments; Accounting for Construction Contracts; Accounting for Reorganization of Debt; Accounting for Intangibles; Accounting for Contingencies; Accounting for Borrowing Costs; Accounting for Leasing; Accounting for Non-cash Transactions; Accounting for After-balance Date Events; Cash Flow Statement; and Disclosure of Relatedparty Transactions.

The standard which relates to intangible assets is: Accounting Standard for Business Enterprise: Accounting for Intangibles. Similar to the Australian case, intangible assets can be classified as either identifiable intangible assets or nonidentifiable intangible assets. Identifiable intangible assets include patents, nonproprietary technologies, brand names, copyrights, land use rights, franchises and suchlike. 'Non-identifiable intangible assets' refers to goodwill.

In this standard intangibles, including goodwill, are required to be amortized using the straight-line method over their useful lives and no more than 10 years 
(MOF 2001). Firms are to value their intangibles each year, and if the book value is greater than their recoverable value, they are required to provide for the devaluation. Both in China and Australia, internally generated goodwill is not allowed to be recognized as an asset.

In China, $\mathrm{R} \& \mathrm{D}$ costs incurred prior to legally obtaining an intangible asset such as a patent are to be expensed in the period when they are incurred. All intangible assets that are developed by the enterprise itself and are obtained by legal application, including patents, brand names, copyrights and franchises, should be measured at cost, including expenditure such as registration fees and legal fees incurred for legal application of obtaining the asset (Ministry of Finance 2001).

\subsection{Hypothesis development}

This chapter addresses two fundamental accounting research questions:

- Are accounting treatments of intangible assets associated with the investment market's valuation of the firm?

- Does capitalization of intangible assets have different relevance to the market valuation of firms in countries with developed and developing capital markets, and with different accounting rules (in particular in Australia and China)?

Although research on intangibles is limited by the availability of data, the extant research nonetheless provides insights into the issue. Researchers have found that there is a strong association between the capitalization of intangible assets and firm valuation. Most of their work focuses on assessing whether investors value separate categories of two capitalized identifiable intangibles: goodwill and $R \& D$.

Lev and Sougiannis (1996) investigate the value relevance of R\&D in the US, where R\&D must be expensed as incurred. By estimating amounts that would be capitalized according to the historical success of R\&D, they find that notional capitalization of R\&D is strongly associated with stock prices and returns. Their findings indicate that the $R \& D$ capitalization process yields value-relevant information for investors. Aboody and Lev (1998) further examine the relevance to investors of information on the capitalization of software development costs. Capitalization of software is the only exception in the US to the full expensing rule for R\&D. They find that annually capitalized development costs are positively associated with share returns, and the accumulated software asset reported on the balance sheet is associated with share prices. They suggest that there is no evidence to support the view that software capitalization decreases the quality of reported earnings.

Consistent with the US findings, Abrahams and Sidhu (1998) find that R\&D capitalization by managers of Australian firms is value-relevant and that $R \& D$ capitalization improves accounting-based measures of firm performance for Australian firms in industries where R\&D activity is widespread. In contrast, 


\section{Jayne M. Godfrey and Wei Lu}

while Godfrey and Koh (2001) find that capitalized intangible assets in aggregate and capitalized goodwill and capitalized identifiable intangible assets other than $R \& D$ are value-relevant, they also find that capitalized $R \& D$ is not value-relevant. ${ }^{4}$ Godfrey and Koh (2001) attribute the differences between their results and those of Abrahams and Sidhu (1998) mostly to the Abrahams and Sidhu (1998) use of a larger sample that includes smaller firms whose equity values are likely to be more reliant upon $R \& D$ growth options.

Barth and Clinch (1996) investigate the value relevance of goodwill to USlisted UK, Australian, and Canadian firms. They find that differences in accounting for goodwill provide incremental power in explaining share returns or prices. This chapter extends their research by including firms that are not US listed, and by investigating accounting practices in relation to other intangibles. This is important as US listing is likely to affect a firm's share price, not only in the US but also on other stock exchanges such as the London Stock Exchange or the Australian Stock Exchange. While investigating goodwill-accounting relevance to US share prices is important, the findings do not necessarily apply to the many firms that are not US listed, nor to domestic pricing of cross-listed firms.

Research on the value relevance of financial reporting disclosures in general in an emerging capital market such as China is very limited. ${ }^{5}$ Investigation into the value relevance of certain areas of financial reporting (such as intangible assets) is even more limited. There are probably two reasons for this. First, the data for Chinese listed companies in the Shanghai and Shenzhen Stock Exchanges cannot be obtained easily. However, the situation is improving as some databases such as COMPUSTAT and Datastream begin to include Chinese firms. Although these databases' coverage of Chinese listed firms is not as complete as for Australian, US or UK firms, it is nonetheless useful for research. Second, the unique institutional environment in China (such as the dominance of state ownership) has sometimes been seen as a barrier to conducting this kind of research.

Within the Australian accounting conceptual framework, assets are future economic benefits controlled by an entity (AASB 1995). Similar definitions are used worldwide, and in China assets are defined as economic resources which are measurable by money value and which are owned or controlled by an enterprise (MOF 2001). Furthermore, accounting rules internationally tend to be conservative in prescribing when assets can be recognized in the accounts. In Australia, they may only be recognized when it is probable that the benefits will be perceived (probability $>50$ per cent) and the asset can be measured reliably (AASB 1995). Thereafter specific rules apply, as has been explained in the context of intangible assets.

As a general proposition, if managers capitalize only those expenditures that give rise to future economic benefits, there should be a positive association between capitalized intangible assets and the market value of equity. This gives rise to hypothesis 1 . 


\section{Hypothesis 1:}

There is a positive association between the market value of equity and the book values of capitalized intangible assets.

More specifically, investors are likely to value individual classes of intangibles differently, according to the probable timing and magnitude of the potential benefits to be realized. As such, hypothesis 1 lends itself to subdivision as follows:

There is a positive association between the market value of equity and the book values of:

- capitalized goodwill (hypothesis 1a)

- capitalized R\&D (hypothesis $1 b$ )

- capitalized brand names (hypothesis 1c)

- capitalized licence costs (hypothesis 1d)

- capitalized deferred costs (hypothesis 1e)

The value of equity is derived from the value of tangible and intangible assets less the value of liabilities. As such, if the market value of equity is modelled as a function of the value of tangible assets less liabilities, inclusion of intangibles should improve the model and explain more of the value of equity. Adopting the approach used to expand hypothesis 1 leads to the following predictions:

\section{Hypothesis 2:}

Including the total of capitalized intangible assets significantly increases the explanatory power of models of the market value of equity as a function of total tangible assets less total liabilities.

The explanatory power of models of the market value of equity as a function of the book values of total tangible assets less total liabilities increases significantly when the following classes of assets are included in the model:

- capitalized goodwill (hypothesis 2a)

- capitalized R\&D (hypothesis $2 b$ )

- capitalized brand names (hypothesis 2c)

- capitalized licence costs (hypothesis $2 \mathrm{~d}$ )

- capitalized deferred costs (hypothesis 2e) 


\subsection{Research method}

\subsubsection{Valuation models}

Tests of the hypotheses use the simple model applied by Abrahams and Sidhu (1998) and Godfrey and Koh (2001). Intangible assets are divided into five categories: goodwill, R\&D, brand names, deferred costs, and licences.

The base model is as follows:

$\mathrm{MVE}_{\mathrm{it}}=\alpha_{0}+\alpha_{1} \mathrm{TTA}_{\mathrm{it}}+\alpha_{2} \mathrm{TL}_{\mathrm{it}}+\varepsilon_{\mathrm{it}}$

(1)

Including intangible assets at different levels of disaggregation leads to the following models:

\begin{tabular}{|c|c|c|}
\hline \multicolumn{3}{|c|}{$\mathrm{MVE}_{\mathrm{it}}=\underset{(2)}{\alpha_{0}}+\alpha_{1} \mathrm{TTA}_{\mathrm{it}}+\alpha_{2} \mathrm{TL}_{\mathrm{it}}+\alpha_{3} \mathrm{TIA}_{\mathrm{it}}+\varepsilon_{\mathrm{it}}$} \\
\hline \multicolumn{3}{|c|}{$\mathrm{MVE}_{\mathrm{it}}=\underset{\text { (3) }}{\alpha 0}+\alpha_{1} \mathrm{TTA}_{\mathrm{it}}+\alpha_{2} \mathrm{TL}_{\mathrm{it}}+\alpha_{4} \mathrm{GW}_{\mathrm{it}}+\alpha_{5} \mathrm{RD}_{\mathrm{it}}+\alpha_{6} \mathrm{IIA}_{\mathrm{it}}+\varepsilon_{\mathrm{it}}$} \\
\hline \multicolumn{3}{|c|}{$\begin{aligned} M V E_{i t} & =\alpha_{0}+\alpha_{1} T_{T A} A_{i t}+\alpha_{2} \mathrm{TL}_{\mathrm{it}}+\alpha_{4} \mathrm{GW}_{\mathrm{it}}+\alpha_{5} \mathrm{RD}_{\mathrm{it}}+\alpha_{7} \mathrm{BN}_{\mathrm{it}}++\alpha_{8} \mathrm{DC}_{\mathrm{it}}+\alpha_{9} \mathrm{LC}_{\mathrm{it}}+\varepsilon_{\mathrm{it}}\end{aligned}$} \\
\hline \multicolumn{3}{|c|}{ Where } \\
\hline MVE & $=$ & market value of equity \\
\hline TTA & $=$ & total tangible assets \\
\hline TL & $=$ & total liabilities \\
\hline TIA & $=$ & total intangible assets \\
\hline GW & $=$ & goodwill \\
\hline $\mathrm{RD}$ & $=$ & research \& development; \\
\hline IIA & $=$ & $\begin{array}{l}\text { total identifiable intangible assets other } \\
\text { than } R \& D\end{array}$ \\
\hline $\mathrm{BN}$ & $=$ & brand names \& patents \\
\hline DC & $=$ & deferred cost \\
\hline $\mathrm{LC}$ & $=$ & licences costs \\
\hline
\end{tabular}

Following the Abrahams and Sidhu (1998) approach, all variables are scaled by total paid up ordinary capital to reduce heteroskedasticity. Equation (2) tests the value-relevance of capitalized total intangible assets. If capitalization of intangible assets is value relevant, then $\alpha_{3}$ will be significantly greater than zero. Equations (3) and (4) test the value relevance of individual groups of capitalized intangible assets. If $\alpha_{4}, \alpha_{5}, \alpha_{7}, \alpha_{8}$ or $\alpha_{9}$ is significantly greater than zero, then investors deem capitalization of the associated individual type of intangible assets to be value-relevant and to be measured with some reliability (Barth 2000). 
As well as examining whether capitalized intangible assets are value-relevant, the study investigates the extent to which capitalized intangible assets add to the power of other balance sheet items, such as total liabilities and total tangible assets, to explain equity value. Hierarchical multiple regression analysis measures the incremental explanatory power of an additional independent variable or a block of independent variables. It does this by testing whether there is a statistically significant increase in the power of several variables (such as tangible assets, liabilities) to explain variation in a dependent variable (such as equity market value) as a result of the additional independent variable or block of independent variables (Tabachnick and Fidell 1989).

\subsection{Sample selection}

As reported in Table 6.2, the Australian and Chinese samples include all firms that (1) are included in the Company Analysis database for 2001 for each country; ${ }^{6}$ and (2) report goodwill or other types of intangible assets ${ }^{7}$ in their 2001 annual reports. These two criteria result in 636 Australian and 197 Chinese firms respectively.

Table 6.2 Sample selection

Sample Selection Sample

Company Analysis database coverage:

Australia

China

Final sample size after omission of firms with negative book value and missing observation of market value, intangibles (2001)

Sample size

Australia

China

\subsection{Results and discussion}

\subsubsection{Descriptive statistics}

Table 6.3 summarizes the industry distribution of these firms. It also provides information about different types of intangible assets reported by these firms according to the industry and country of firm listing. Table 6.3 shows that in Australia 419 firms (66 per cent) report goodwill. 
Table 6.3 Industry distributions

\begin{tabular}{|c|c|c|c|c|c|c|c|c|c|c|c|c|c|c|}
\hline Countries & Australia & & & & & & & China & & & & & & \\
\hline 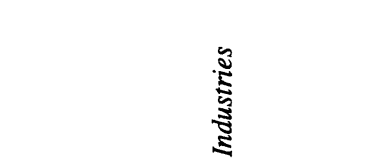 & $\vec{\Xi}$ & 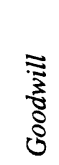 & \&્ટ & $\frac{1}{0}$ & 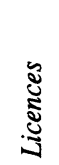 & 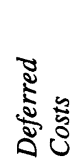 & 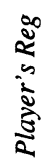 & $\bar{\Xi}$ & $\begin{array}{l}\overline{5} \\
\frac{5}{8} \\
8\end{array}$ & $\stackrel{\mathbb{Z}}{*}$ & 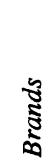 & 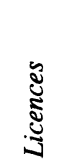 & 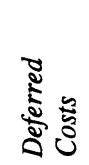 & 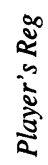 \\
\hline Aerospace \& Defence & 1 & 0 & 0 & 0 & 0 & 0 & 0 & 0 & 0 & 0 & 0 & 0 & 0 & 0 \\
\hline Automobiles \& Parts & 9 & 8 & 6 & 4 & 1 & 2 & 0 & 11 & 2 & 1 & 4 & 5 & 6 & 0 \\
\hline Beverages & 15 & 15 & 3 & 9 & 1 & 4 & 0 & 5 & 2 & 0 & 4 & 3 & 2 & 0 \\
\hline Chemicals & 11 & 6 & 3 & 8 & 1 & 2 & 0 & 7 & 2 & 0 & 2 & 2 & 3 & 0 \\
\hline $\begin{array}{l}\text { Construction \& Building } \\
\text { Materials }\end{array}$ & 25 & 19 & 4 & 6 & 1 & 4 & 0 & 14 & 4 & 1 & 3 & 9 & 6 & 0 \\
\hline Distributors & 25 & 19 & 4 & 7 & 3 & 2 & 0 & 4 & 3 & 0 & 0 & 0 & 2 & 0 \\
\hline Diversified Industries & 7 & 7 & 2 & 3 & 1 & 2 & 0 & 8 & 3 & 0 & 3 & 5 & 6 & 0 \\
\hline Electricity & 6 & 1 & 1 & 2 & 3 & 1 & 0 & 11 & 4 & 1 & 1 & 4 & 7 & 0 \\
\hline Electronic \& Electrical & 28 & 21 & 7 & 12 & 6 & 9 & 0 & 32 & 11 & 3 & 11 & 13 & 15 & 0 \\
\hline Engineering \& Machinery & 26 & 21 & 6 & 13 & 1 & 10 & 0 & 20 & 7 & 1 & 7 & 6 & 8 & 0 \\
\hline Food Producers \& Processors & 26 & 18 & 2 & 13 & 3 & 7 & 0 & 2 & 0 & 0 & 1 & 0 & 2 & 0 \\
\hline Food \& Drug Retailers & 7 & 6 & 2 & 3 & 1 & 2 & 0 & 2 & 0 & 0 & 0 & 0 & 0 & 0 \\
\hline
\end{tabular}

(continued) 
Table 6.3 Industry distributions (Continued)

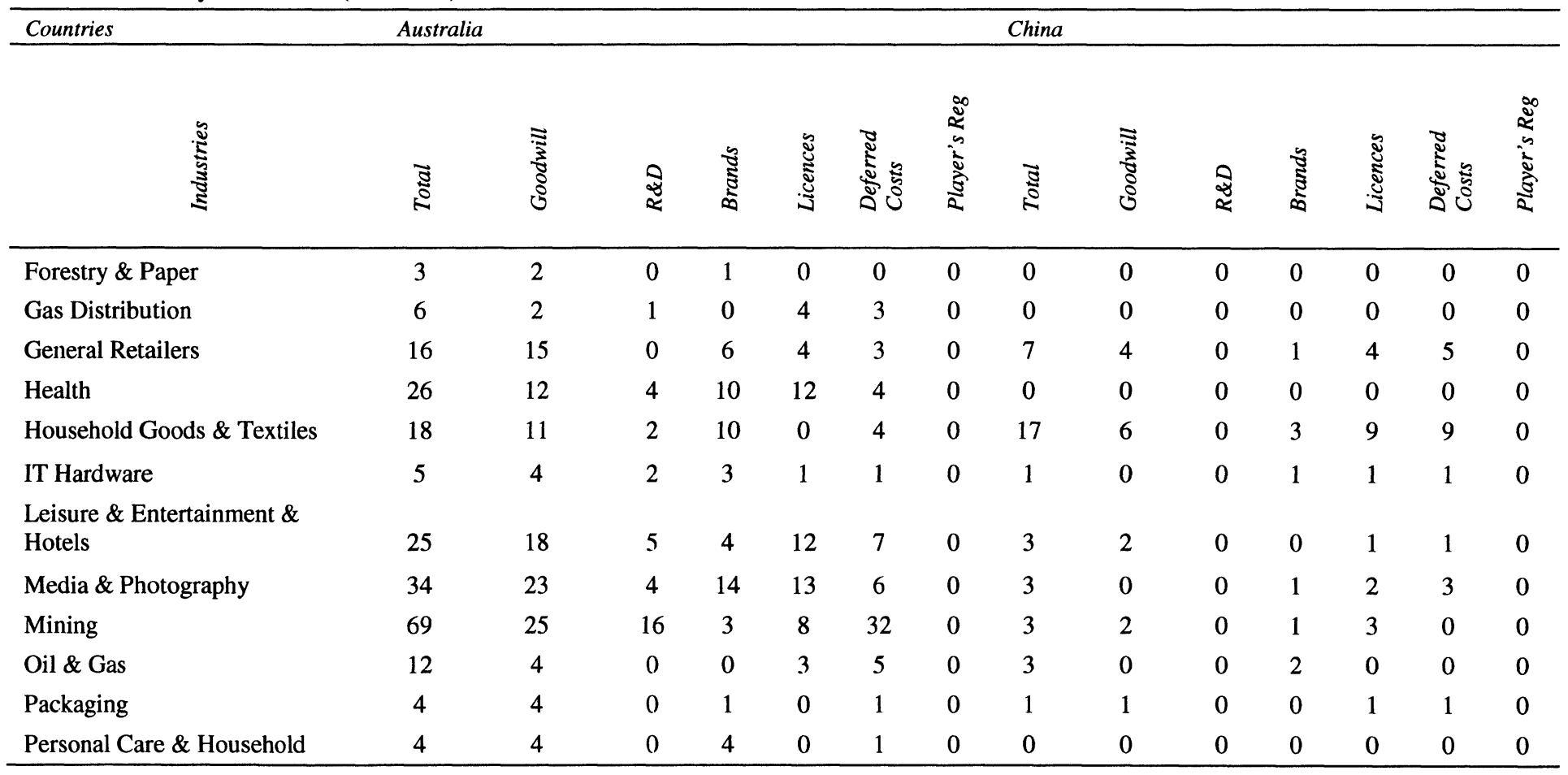

(continued) 
Table 6.3 Industry distributions (Continued)

\begin{tabular}{|c|c|c|c|c|c|c|c|c|c|c|c|c|c|c|}
\hline Countries & Australia & & & & & & & China & & & & & & \\
\hline 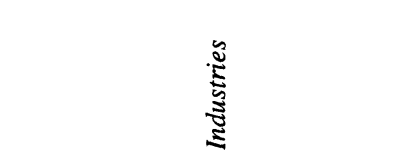 & ఫేँ & 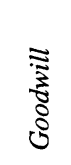 & ષ્ષ & $\frac{\mathfrak{s}}{\tilde{s}}$ & 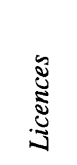 & 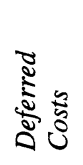 & 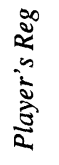 & $\underset{\mathbb{Z}}{\tilde{\Xi}}$ & 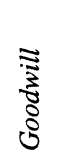 & \&ి & 忥 & 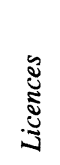 & 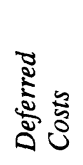 & 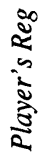 \\
\hline Pharmaceuticals & 27 & 12 & 8 & 11 & 7 & 5 & 0 & 13 & 1 & 1 & 2 & 6 & 5 & 0 \\
\hline Software \& Computer Services & 84 & 55 & 29 & 27 & 20 & 16 & 0 & 7 & 1 & 0 & 2 & 4 & 3 & 0 \\
\hline Speciality \& Other Finance & 0 & 0 & 0 & 0 & 0 & 0 & 0 & 0 & 0 & 0 & 0 & 0 & 0 & 0 \\
\hline Steel \& Other Metals & 5 & 3 & 1 & 3 & 0 & 1 & 0 & 3 & 0 & 0 & 1 & 2 & 1 & 0 \\
\hline Support Services & 63 & 49 & 9 & 24 & 13 & 9 & 0 & 1 & 0 & 0 & 0 & 1 & 1 & 0 \\
\hline Telecommunication Services & 29 & 20 & 7 & 8 & 13 & 7 & 0 & 2 & 0 & 0 & 0 & 1 & 1 & 0 \\
\hline Tobacco & 0 & 0 & 0 & 0 & 0 & 0 & 0 & 0 & & & & & & \\
\hline Transport & 19 & 15 & 1 & 6 & 5 & 9 & 0 & 16 & 6 & 0 & 1 & 4 & 9 & 0 \\
\hline Unknown & 0 & 0 & 0 & 0 & 0 & 0 & 0 & 0 & 0 & 0 & 0 & 0 & 0 & 0 \\
\hline Water & 1 & 0 & 0 & 1 & 0 & 0 & 0 & 1 & 0 & 0 & 0 & 0 & 0 & 0 \\
\hline Total & 636 & 419 & 129 & 216 & 137 & 159 & 0 & 197 & 61 & 8 & 51 & 86 & 97 & 0 \\
\hline
\end{tabular}


This contrasts with the Godfrey and Koh (2001) sample where 85 per cent of companies report goodwill. The difference is due to the sample of this study encompassing smaller firms that have not engaged in business acquisitions. ${ }^{8}$ In contrast, 129 out of 636 firms capitalize R\&D ( 20 per cent of the sample firms). The majority of the 216 firms ( 34 per cent) that capitalize and amortize R\&D are in the automobiles \& parts, banking, electronic \& electrical, food \& drug retail and software \& computer service industries.

Other identifiable intangibles capitalized by the sample firms include brand names \& patents, licences, and deferred costs. Fifty per cent of firms report at least one identifiable intangible asset. Thirty-four per cent of firms report brand names and patents, 22 per cent report licences, and 25 per cent report deferred costs. Of the 216 firms that capitalize brand names and patents 53 firms (38 per cent) do not amortize them. This includes $41 \mathrm{firms}$ with capitalized brands exceeding 10 per cent of their total reported assets.

In contrast to Australian samples, Chinese firms are much less likely to report goodwill $(n=61 ; 31$ per cent) or $R \& D(n=8 ; 4$ per cent). There are several potential reasons for this. First, most listed firms are directly or indirectly controlled by the state. These firms are less likely, compared to Australian firms, to engage in complicated business activities such as merger and acquisition. Therefore, there are far fewer opportunities for them to report goodwill resulting from such activities. Second, China has been attempting to implement accounting reforms by issuing its own accounting standards along IFRS lines. However, many unique features of China's institutional environment may hinder or delay enforcement.

According to a recent study by Xue and Wang (2002), there is a lack of understanding of how R\&D should be measured (expense vs capitalization) and disclosed. Many firms simply disclose R\&D expenses as part of the operating expense without a footnote disclosure explaining the actual annual spending on R\&D. Of the Xue and Wang (2002) sample of 209 firms listed on the Shanghai Stock Exchange in 1998, no firms disclosed information on R\&D. This situation is certainly improving, with this chapter's 2001 sample showing that 8 out of 197 firms (over 4 per cent) reported capitalized R\&D. More improvement can be expected in the future because both the investment and accounting communities will be more aware of the international practice on R\&D disclosure, particularly IAS 38 Intangible Assets, and of the important association between a firm's R\&D spending and its productivity.

Approximately 25 per cent of the Chinese sample capitalizes brand names and almost 50 per cent of the firms capitalize deferred costs and licence costs.

Table 6.4 shows descriptive statistics for the two countries' dependent and independent variables. After allowing for currency exchange rates, it is clear that Australian firms are larger than Chinese firms. For all firms the data are skewed, and additional transformations normalize the measures and ensure reduced heteroskedasticity for hypothesis testing. For Australia, intangible assets comprise 20 per cent of reported total assets respectively. For China, they comprise only 2 per cent. 
Table 6.4 Descriptive statistics

\begin{tabular}{|c|c|c|c|c|c|c|c|c|c|c|c|c|}
\hline \multirow[t]{2}{*}{ Variables } & \multicolumn{6}{|c|}{ Australia (in thousands of $A \$$ ) } & \multicolumn{6}{|c|}{ China (in thousands of $R M B$ ) } \\
\hline & $N$ & $\begin{array}{l}\text { Mean } \\
(\$ 000)\end{array}$ & $\begin{array}{l}\text { Median } \\
(\$ 000)\end{array}$ & Std.dev & $\begin{array}{l}\text { Min } \\
(\$ 000)\end{array}$ & $\begin{array}{l}\operatorname{Max} \\
(\$ 000)\end{array}$ & $N$ & $\begin{array}{l}\text { Mean } \\
(\$ 000)\end{array}$ & $\begin{array}{l}\text { Median } \\
(\$ 000)\end{array}$ & Std.dev & $\begin{array}{l}\text { Min } \\
(\$ 000)\end{array}$ & $\begin{array}{l}\operatorname{Max} \\
(\$ 000)\end{array}$ \\
\hline TA & 636 & 717396.2 & 38492 & 42238045 & 158.1380 & 84961000 & 197 & 6632242 & 2456970 & 32943867 & 57437 & $4.61 \mathrm{E}+08$ \\
\hline TIA & 636 & 135679.7 & 4735 & 1295146 & 0.23 & 31570000 & 197 & 143652.6 & 48311 & 255923.5 & 23 & 1671358 \\
\hline TTA & 636 & 577974.3 & 27792 & 3142339 & 154.8780 & 53391000 & 197 & 6488590 & 2413941 & 32825839 & 52315 & $4.59 \mathrm{E}+08$ \\
\hline TL & 636 & 416689.2 & 15892 & 23356329 & 3.589 & 42421000 & 197 & 2960999 & 1134212 & 12203714 & 11092 & $1.68 \mathrm{E}+08$ \\
\hline MVE & 636 & 763555.5 & 32512 & 49786348 & 757 & 79653000 & 197 & 3504221 & 1979518 & 5609137 & 10269 & 43589570 \\
\hline GW & 419 & 54546.35 & 3817.396 & 189701.8 & 8 & 1998000 & 61 & 56276.97 & 16892.50 & 133504.4 & 65 & 786620 \\
\hline RD & 129 & 21133.05 & 1238 & 146688.1 & 26 & 1625000 & 8 & 16972.4 & 8766.603 & 25468.37 & 26 & 78209 \\
\hline $\mathrm{BN}$ & 216 & 177587.9 & 1768.385 & 2112342 & 0.82 & 31051000 & 51 & 66647.7 & 9611 & 213959.7 & 27 & 1305000 \\
\hline DC & 159 & 21323.89 & 1282 & 106390.5 & 0.23 & 1196000 & 97 & 33641.19 & 9136 & 59429.65 & 23 & 288640 \\
\hline LC & 137 & 104630.2 & 1444 & 327843.4 & 5 & 2789176 & 86 & 107211.9 & 47503 & 179166.8 & 259 & 1144178 \\
\hline PR & 0 & 0 & 0 & 0 & 0 & 0 & 0 & 0 & 0 & 0 & 0 & 0 \\
\hline
\end{tabular}




\subsubsection{Value relevance in Australia and China}

Table 6.5 Model 1 reports a very simple model of the market value of equity as a function of only reported tangible assets and liabilities. For Australian firms it is significant $(F=80 ; p<0.01)$ and explains 22 per cent of the variation in the market value of equity. The significance remains, the coefficient on the total intangible assets is significant and positive, as expected $(\mathrm{p}<0.01)$, and the explanatory power of the model increases to 71 per cent in Model 2 as the aggregate of intangible assets is added to the independent variables. Hence, hypothesis 1 is supported. Each dollar of aggregated total intangible assets is valued at $\$ 8.00$ in the market value of equity.

Table 6.5 Model 3 incorporates total tangible assets, total liabilities, and three categories of intangible assets: goodwill, R\&D and other intangible assets. For Australian firms the explanatory power is 89 per cent, a significant increase from Model 2, which aggregates intangibles as one measure. Furthermore, the coefficients on both goodwill and R\&D are positive and significant, supporting hypotheses $1 \mathrm{a}$ and $1 \mathrm{~b}$. Once aggregate intangible assets are segregated into goodwill, R\&D and other intangibles, the market value of equity reflects far greater values for the individual intangibles than the aggregate of all intangibles. Each dollar of goodwill is valued at $\$ 6.65$, and each dollar of $R \& D$ is valued at $\$ 15.49$. The aggregate of brand names, deferred costs, licence costs and other intangible assets is also significant, with a positive coefficient. The results are consistent with investors believing that the growth options inherent in unidentifiable intangible assets and in R\&D expenditure are of far greater value to shareholders than the amount spent on (and still capitalized in) those assets.

Model 4 has the same explanatory power as Model 3, but demonstrates that there is a strong economic association between deferred costs and equity value ( $\$ 3.17$ equity value for each $\$ 1$ of deferred costs), and that licence costs are valued at approximately twice their cost $(\$ 2.24)$. As such, hypotheses $1 \mathrm{~d}$ and $1 \mathrm{e}$ are supported. Goodwill and R\&D remain significant $(\mathrm{p}<0.01)$. Presumably the reflection of these intangibles in the market value of equity arises because the market believes that accounting is conservative and that the costs are carried forward rather than expensed only when their value is assured and of significantly greater value than the amount spent on deferred costs or licences. Brand names are also significantly related to the market value of equity $(\mathrm{p}<0.01)$, and hypothesis $1 \mathrm{c}$ is supported in that the market values each dollar of brand names at $\$ 1.68$.

Interestingly, in Models 3 and 4, the individual intangible assets each have larger coefficients than the coefficient on total tangible assets. This is consistent with the view that intangible assets are growth options whose value exceeds that of assets in place (Myers 1977). The fact that total intangible assets in Model 2 has a smaller coefficient than the coefficients for individual classes of intangible assets in Models 3 and 4 reveals that the market weights individual intangible assets differently when valuing equity, and that while their aggregate is regarded as significant, it is the composition of the aggregate that is more important to investors. 
Table 6.5 Regression of market value of equity on capitalized intangible assets and other balance sheet items

\begin{tabular}{|c|c|c|c|c|c|c|c|c|c|}
\hline \multicolumn{6}{|c|}{$\mathrm{MVE}_{\mathrm{it}}=\alpha_{0}+\alpha_{1} \mathrm{TTA}_{\mathrm{it}}+\alpha_{2} \mathrm{TL}_{\mathrm{it}}+\varepsilon_{\mathrm{it}}$} & \multicolumn{4}{|c|}{ (1) } \\
\hline \multicolumn{6}{|c|}{$\mathrm{MVE}_{\mathrm{it}}=\alpha_{0}+\alpha_{1} \mathrm{TTA}_{\mathrm{it}}+\alpha_{2} \mathrm{TL}_{\mathrm{it}}+\alpha_{3} \mathrm{TIA}_{\mathrm{it}}+\varepsilon_{\mathrm{it}}$} & \multicolumn{4}{|c|}{ (2) } \\
\hline \multicolumn{6}{|c|}{$\mathrm{MVE}_{\mathrm{it}}=\alpha 0+\alpha_{1} \mathrm{TTA}_{\mathrm{it}}+\alpha_{2} \mathrm{TL}_{\mathrm{it}}+\alpha_{4} \mathrm{GW}_{\mathrm{it}}+\alpha_{5} \mathrm{RD}_{\mathrm{it}}+\alpha_{6} \mathrm{IIA}_{\mathrm{it}}+\varepsilon_{\mathrm{it}}$} & \multicolumn{4}{|c|}{ (3) } \\
\hline \multirow[b]{2}{*}{ Variables } & \multirow[b]{2}{*}{$\begin{array}{l}\text { Predicted } \\
\text { Sign }\end{array}$} & \multicolumn{4}{|c|}{ Australia } & \multicolumn{4}{|l|}{ China } \\
\hline & & $\begin{array}{l}\text { Model I } \\
\text { Coefficient } \\
\text { (2-tailed } p- \\
\text { value }\end{array}$ & $\begin{array}{l}\text { Model } 2 \\
\text { Coefficient } \\
\text { (2-tailed p- } \\
\text { value } \\
\end{array}$ & $\begin{array}{l}\text { Model } 3 \\
\text { Coefficient } \\
\text { (2-tailed p- } \\
\text { value }\end{array}$ & $\begin{array}{l}\text { Model } 4 \\
\text { Coefficient } \\
\text { (2-tailed p- } \\
\text { value } \\
\end{array}$ & $\begin{array}{l}\text { Model 1 } \\
\text { Coefficient } \\
\text { (2-tailed p- } \\
\text { value }\end{array}$ & $\begin{array}{l}\text { Model } 2 \\
\text { Coefficient } \\
\text { (2-tailed p- } \\
\text { value }\end{array}$ & $\begin{array}{l}\text { Model } 3 \\
\text { Coefficient } \\
\text { (2-tailed p- } \\
\text { value } \\
\end{array}$ & $\begin{array}{l}\text { Model } 4 \\
\text { Coefficient } \\
\text { (2-tailed p- } \\
\text { value }\end{array}$ \\
\hline \multirow[t]{2}{*}{ Intercept } & & 1.074889 & -2.837753 & -0.724539 & -0.646978 & 3.319872 & 3.212440 & 3.176059 & 3.246915 \\
\hline & & $(0.1041)$ & $(0.0000)$ & $(0.0003)$ & $(0.0000)$ & $(0.0005)$ & $(0.0010)$ & $(0.0011)$ & $(0.0009)$ \\
\hline \multirow[t]{2}{*}{ TTA } & + & 3.240701 & 3.934713 & 2.287633 & 2.221694 & 0.700895 & 0.719540 & 0.690994 & 0.684057 \\
\hline & & $(0.0000)$ & $(0.0000)$ & $(0.0000)$ & $(0.0000)$ & $(0.0289)$ & $(0.0258)$ & $(0.0332)$ & $(0.0364)$ \\
\hline \multirow[t]{2}{*}{$\mathrm{TL}$} & - & -3.693586 & -4.663850 & -2.634748 & -2.531446 & -0.536259 & -0.591712 & -0.538333 & -0.525903 \\
\hline & & $(0.0000)$ & $(0.0000)$ & $(0.0000)$ & $(0.0000)$ & $(0.1851)$ & $(0.1540)$ & $(0.1989)$ & $(0.2109)$ \\
\hline GW & & & & $(0.0000)$ & $(0.0000)$ & & & $(0.6869)$ & $(0.6690)$ \\
\hline \multirow[t]{2}{*}{ RD } & + & & & 15.49353 & 15.47435 & & & 26.40027 & 25.97897 \\
\hline & & & & $(0.0000)$ & $(0.0000)$ & & & $(0.3064)$ & $(0.3166)$ \\
\hline \multirow[t]{2}{*}{$\mathrm{BN}$} & + & & & & 1.675755 & & & & -1.050938 \\
\hline & & & & & $(0.0000)$ & & & & $(0.8111)$ \\
\hline
\end{tabular}

(continued) 
Table 6.5 Regression of market value of equity on capitalized intangible assets and other balance sheet items (Continued)

\begin{tabular}{|c|c|c|c|c|c|c|c|c|c|}
\hline \multicolumn{6}{|c|}{$\mathrm{MVE}_{\mathrm{it}}=\alpha_{0}+\alpha_{1} \mathrm{TTA}_{\mathrm{it}}+\alpha_{2} \mathrm{TL}_{\mathrm{it}}+\varepsilon_{\mathrm{it}}$} & \multicolumn{4}{|l|}{ (1) } \\
\hline \multicolumn{6}{|c|}{$\mathrm{MVE}_{\mathrm{it}}=\alpha_{0}+\alpha_{1} \mathrm{TTA}_{\mathrm{it}}+\alpha_{2} \mathrm{TL}_{\mathrm{it}}+\alpha_{3} \mathrm{TIA}_{\mathrm{it}}+\varepsilon_{\mathrm{it}}$} & \multicolumn{4}{|l|}{ (2) } \\
\hline \multicolumn{6}{|c|}{$\mathrm{MVE}_{\mathrm{it}}=\alpha 0+\alpha_{1} \mathrm{TTA}_{\mathrm{it}}+\alpha_{2} \mathrm{TL}_{\mathrm{it}}+\alpha_{4} \mathrm{GW}_{\mathrm{it}}+\alpha_{5} \mathrm{RD}_{\mathrm{it}}+\alpha_{6} \mathrm{IIA}_{\mathrm{it}}+\varepsilon_{\mathrm{it}}$} & \multicolumn{4}{|l|}{ (3) } \\
\hline \multicolumn{6}{|c|}{$\mathrm{MVE}_{\mathrm{it}}=\alpha_{0}+\alpha_{1} \mathrm{TTA}_{\mathrm{it}}+\alpha_{2} \mathrm{TL}_{\mathrm{it}}+\alpha_{4} \mathrm{GW}_{\mathrm{it}}+\alpha_{5} \mathrm{RD}_{\mathrm{it}}+\alpha_{7} \mathrm{BN}_{\mathrm{it}}++\alpha_{8} \mathrm{DC}_{\mathrm{it}}+\alpha_{9} \mathrm{LC}_{\mathrm{it}}+\varepsilon_{\mathrm{it}}$} & \multicolumn{4}{|l|}{ (4) } \\
\hline \multirow[b]{2}{*}{ Variables } & \multirow[b]{2}{*}{$\begin{array}{l}\text { Predicted } \\
\text { Sign }\end{array}$} & Australia & & & & China & & & \\
\hline & & $\begin{array}{l}\text { Model } 1 \\
\text { Coefficient } \\
\text { (2-tailed p- } \\
\text { value }\end{array}$ & $\begin{array}{l}\text { Model } 2 \\
\text { Coefficient } \\
\text { (2-tailed p- } \\
\text { value }\end{array}$ & $\begin{array}{l}\text { Model } 3 \\
\text { Coefficient } \\
\text { (2-tailed p- } \\
\text { value }\end{array}$ & $\begin{array}{l}\text { Model } 4 \\
\text { Coefficient } \\
\text { (2-tailed p- } \\
\text { value } \\
\end{array}$ & $\begin{array}{l}\text { Model } 1 \\
\text { Coefficient } \\
\text { (2-tailed p- } \\
\text { value }\end{array}$ & $\begin{array}{l}\text { Model } 2 \\
\text { Coefficient } \\
\text { (2-tailed p- } \\
\text { value }\end{array}$ & $\begin{array}{l}\text { Model } 3 \\
\text { Coefficient } \\
\text { (2-tailed } p- \\
\text { value }\end{array}$ & $\begin{array}{l}\text { Model } 4 \\
\text { Coefficient } \\
\text { (2-tailed } p- \\
\text { value }\end{array}$ \\
\hline \multirow[t]{2}{*}{ DC } & + & & & & 3.169001 & & & & -0.634962 \\
\hline & & & & & $(0.0000)$ & & & & $(0.8301)$ \\
\hline \multirow[t]{2}{*}{ LC } & + & & & & 2.238444 & & & & 1.831018 \\
\hline & & & & & $(0.0000)$ & & & & $(0.8301)$ \\
\hline PR & + & & & & & & & & \\
\hline $\begin{array}{l}\mathrm{BN}+\mathrm{DC}+\mathrm{LC} \\
+\mathrm{PA}+\mathrm{OTHERS}\end{array}$ & & & & $\begin{array}{l}2.163909 \\
(0.0000)\end{array}$ & & & & $\begin{array}{l}0.908653 \\
(0.4651)\end{array}$ & \\
\hline $\mathrm{N}$ & 636 & 636 & 636 & 636 & 636 & 197 & 197 & 197 & 197 \\
\hline F-statistic & & $\begin{array}{l}79.58859 \\
(0.0000) \\
\end{array}$ & $\begin{array}{l}475.8921 \\
(0.0000)\end{array}$ & $\begin{array}{l}962.9526 \\
(0.0000)\end{array}$ & $\begin{array}{l}681.2173 \\
(0.0000) \\
\end{array}$ & $\begin{array}{l}3.621808 \\
(0.028658)\end{array}$ & $\begin{array}{l}2.537393 \\
(0.058116)\end{array}$ & $\begin{array}{l}1.771295 \\
(0.120865)\end{array}$ & $\begin{array}{l}1.295244 \\
(0.255030)\end{array}$ \\
\hline Adjusted $R^{2}$ & & 0.2171106 & 0.713597 & 0.893980 & 0.893396 & 0.037876 & 0.039935 & 0.046648 & 0.048210 \\
\hline
\end{tabular}

$\mathrm{TTA}=$ Total tangible assets, $\mathrm{TL}=$ Total liabilities, $\mathrm{TIA}=$ Total intangible assets, $\mathrm{GW}=$ Goodwill, $\mathrm{RD}=$ Research and development cost, $\mathrm{BN}=\mathrm{Brand}$ name, $\mathrm{DC}=$ Deferred costs, $\mathrm{LC}=$ Licences costs, $\mathrm{PR}=$ Player's registration . 


\section{Jayne M. Godfrey and Wei Lu}

For Chinese firms, only Model 1 is significant $(\mathrm{p}<0.05)$. Total tangible assets are value-relevant in all models. However, the explanatory power does not exceed 5 per cent for any of the models, and none of the capitalized intangible assets' book values are significant in their association with the market value of equity.

For Australian firms, hypotheses 1(a) - 1(e) are all supported and the most disaggregated model explains 89 per cent of the market value of equity. In contrast, none of the hypotheses are supported for Chinese firms, and the models explain no more than 5 per cent of the market value of equity. The extreme differences are likely to arise because Australian firms have a tradition of capitalizing identifiable intangible assets and amortizing them in a manner that is relatively consistent across all intangibles, and also because the Australian capital market participants are familiar with the accounting standards that do not permit assets to be capitalized or carried at amounts that exceed their fair values. In contrast, China is an emerging capital market where the accounting rules are not as familiar to participants, and the rules are less consistent across intangibles.

Table 6.6 reports the results of multiple hierarchical regression tests to determine the extent to which adding individual or aggregate intangible asset independent variables or groups of independent variables increases the power of base models to explain variation in the market value of equity. Consistent with the results reported in Table 6.5 , the explanatory power increases relatively significantly for Australian firms when various individual intangible assets or groups of intangible assets are added to an equation modelling the market value of equity as a function of the book value of tangible assets less liabilities. Despite the greater economic significance of deferred costs in modelling equity value for Australian firms, adding R\&D to any base model including total tangible assets, total liabilities, and/or other intangible assets improves the explanatory power of the model far more than adding any other individual intangible asset independent variable, or adding total intangible assets. For Chinese firms, the increase in explanatory power is never significant.

The value relevance of capitalized intangible assets is different in China and Australia. The regressions using Chinese data show little relevance of capitalized assets. This finding is probably a consequence of the fact that the Chinese economy is an emerging economy where accounting has not served the same information role as in Western society, the capital market is in relatively early stages, and the rules governing accounting practice are less well-developed and less familiar to capital market participants. 
Table 6.6 Incremental explanatory power of capitalized intangible assets to models of the market value of equity

\begin{tabular}{|c|c|c|c|c|}
\hline & \multirow[b]{2}{*}{$\begin{array}{l}\text { Base Model Independent } \\
\text { Variables }\end{array}$} & \multirow[b]{2}{*}{$\begin{array}{l}\text { Additional Independent } \\
\text { Variables }\end{array}$} & \multicolumn{2}{|c|}{ Countries } \\
\hline & & & Australia & China \\
\hline 1 & $\begin{array}{l}\text { Total tangible assets; total } \\
\text { liabilities }\end{array}$ & Total intangible assets & $0.497719 * * *$ & $\overline{-}-003222$ \\
\hline 2 & $\begin{array}{l}\text { Total tangible assets; total } \\
\text { liabilities }\end{array}$ & Goodwill & $0.116301 * * *$ & $\overline{0.004847}$ \\
\hline 3 & $\begin{array}{l}\text { Total tangible assets; total } \\
\text { liabilities }\end{array}$ & $\mathrm{R} \& \mathrm{D}$ & $0.60096^{* * *}$ & $\overline{0.000589}$ \\
\hline 4 & $\begin{array}{l}\text { Total tangible assets; total } \\
\text { liabilities }\end{array}$ & Brand names \& patents & $0.004101 *$ & - \\
\hline 5 & $\begin{array}{l}\text { Total tangible assets; total } \\
\text { liabilities }\end{array}$ & Deferred costs & -0.000819 & 0.005184 \\
\hline 6 & $\begin{array}{l}\text { Total tangible assets; total } \\
\text { liabilities }\end{array}$ & Licences & $0.017883 * *$ & - \\
\hline 7 & $\begin{array}{l}\text { Total tangible assets; total } \\
\text { liabilities }\end{array}$ & $\begin{array}{l}\text { Total of brand names, } \\
\text { deferred costs, licence } \\
\text { costs }\end{array}$ & $0.020992 * *$ & $\overline{-} 0.011303$ \\
\hline 8 & $\begin{array}{l}\text { Total tangible assets; total } \\
\text { liabilities; R\&D }\end{array}$ & Goodwill & $0.0673309 * * *$ & $\overline{-}-004019$ \\
\hline 9 & $\begin{array}{l}\text { Total tangible assets; total } \\
\text { liabilities; R\&D; BDLP }\end{array}$ & Goodwill & $0.07297 * * *$ & $\begin{array}{l}- \\
0.004505\end{array}$ \\
\hline 10 & $\begin{array}{l}\text { Total tangible assets; total } \\
\text { liabilities; goodwill; R\&D }\end{array}$ & Brand names \& patents & $0.001178 * *$ & $\overline{-}-005073$ \\
\hline 11 & $\begin{array}{l}\text { Total tangible assets; total } \\
\text { liabilities; goodwill; R\&D }\end{array}$ & $\begin{array}{l}\text { Brand names, deferred } \\
\text { costs, licence costs }\end{array}$ & $0.009393 * * *$ & $\overline{-}-015841$ \\
\hline 12 & $\begin{array}{l}\text { Total tangible assets; total } \\
\text { liabilities; goodwill }\end{array}$ & $\mathrm{R} \& \mathrm{D}$ & $0.55201 * * *$ & 0.000239 \\
\hline 13 & $\begin{array}{l}\text { Total tangible assets; total } \\
\text { liabilities; goodwill; BDLP }\end{array}$ & $\mathrm{R} \& \mathrm{D}$ & $0.533384 * * *$ & 0.00028 \\
\hline 14 & $\begin{array}{l}\text { Total tangible assets; total } \\
\text { liabilities; goodwill }\end{array}$ & Brand names \& patents & $0.004164 *$ & - \\
\hline 15 & $\begin{array}{l}\text { Total tangible assets; total } \\
\text { liabilities }\end{array}$ & Goodwill, R\&D & $0.119965^{* * *}$ & $\overline{0} .004608$ \\
\hline 16 & $\begin{array}{l}\text { Total tangible assets; total } \\
\text { liabilities }\end{array}$ & $\begin{array}{l}\text { Goodwill, R\&D, brand } \\
\text { names and patents }\end{array}$ & $0.669489 * *$ & $\overline{-}-009681$ \\
\hline 17 & $\begin{array}{l}\text { Total tangible assets; total } \\
\text { liabilities; goodwill; R\&D; } \\
\text { BN }\end{array}$ & $\begin{array}{l}\text { Deferred costs; licence } \\
\text { costs }\end{array}$ & $0.008218 * * *$ & 0.006749 \\
\hline
\end{tabular}




\subsection{Conclusion}

The purpose of this chapter has been to investigate the value relevance of capitalizing brand names, deferred costs, goodwill, research and development, and licence costs across two countries: Australia and China. We have investigated the value relevance of capitalizing individual classes of intangible assets, and we have also assessed the value relevance of a capitalized aggregate of intangible assets. Finally, we have examined the incremental value relevance of capitalizing individual classes of intangible asset, conditional upon the capitalization of other classes.

The results indicate that intangible asset classification in aggregate is generally value-relevant for Australian firms $(p<0.01)$. Including capitalized assets in models of the market value of Australian firms' equity increases the explanatory power of those models significantly, but capitalization of individual classes of intangibles is even more value-relevant. Furthermore, the value relevance of research and development $(R \& D)(\$ 15.50, p<0.01)$ and capitalized deferred costs is greatest, with the market attributing $\$ 3.17$ of equity value to every $\$ 1.00$ of capitalized deferred costs $(\mathrm{p}<0.01)$. Goodwill has the next greatest value relevance $(\$ 6.52, \mathrm{p}<0.01)$, and licence costs are also valuerelevant $(\$ 2.24, \mathrm{p}<0.01)$.

The R\&D findings conflict with those of Godfrey and Koh (2001), presumably because this study uses a larger sample that includes more firms with greater growth options inherent in their R\&D. For the Australian sample, capitalizing the individual classes of intangible assets increases the explanatory power of models of the market value of equity from 71 per cent when intangibles are grouped together to 89 per cent when the five different classes of intangibles are included individually. In separate regressions using a base model where no other intangible assets are capitalized, contributions to the increase in explanatory power of models of the market value of equity for Australian firms are greatest from goodwill, then $\mathrm{R} \& \mathrm{D}$, deferred costs, licences and brand names, in that order.

In contrast, for Chinese firms the book value of intangible assets is a very small proportion of the book value of total assets (only 2 per cent compared with 20 per cent of Australian firms). Furthermore, none of the capitalized intangible asset book values are significantly associated with the market value of equity.

One limitation of this study is simultaneously its strength. The limitation is that because the study uses data from a single period in China's early capital market development, it is impossible to determine whether the lack of value relevance of intangible asset capitalization is due to poor measurement in the accounts, to lack of capital market familiarity with the notion of intangible asset capitalization, or to investors buying shares for reasons other than capital gain. The strength from using this early data is that the study, as exploratory research, indicates that there is definitely a difference in the value relevance of capitalized intangible assets for the developed Australian capital market and the developing Chinese capital market. It highlights the potential for, and importance of, future research to explain reasons for that difference. 


\section{Notes}

1 The Urgent Issue Group (UIG) was established in 1994. The UIG is a 16 member committee with members from the profession, preparers of financial statements and government agencies. It was established to deal with accounting issues confronting practitioners, in particular where different interpretations of standards arise. Its pronouncements are in the form of abstracts, which guide accounting practice.

2 Some claimed that the successful takeover of Rowntree (UK) by Nestle (Switzerland) in 1988 was the result of a lack of appreciation of brand values by the stock market.

3 Proposed amendments to IAS 36 Impairment of Assets and IAS 38 Intangible Assets.

4 Using Australian data, Godfrey and Koh (2001) find that capitalization of intangible assets, as a whole, provides information that is relevant for investors in valuing firms. When capitalized intangible assets are disaggregated into goodwill, $R \& D$ and other identifiable intangible assets, both goodwill and other identifiable intangible assets provide relevant valuation information whereas capitalized R\&D costs do not seem to provide information relevant to firms' valuation.

5 Chen et al. (2001) find that accounting information is value-relevant to investors in the Chinese market despite its immaturity and the perception of inadequate accounting and financial reporting in China.

6 The Company Analysis database includes firms whose equity traded on the relevant stock exchanges for the relevant period (for coverage see Table 6.3).

7 Adopting the classifications of Company Analysis all intangible assets have been categorized as goodwill, development costs, brands and patents, licences, deferred costs, player registrations, and unclassified and other intangibles.

8 The Godfrey and Koh (2001) tests use a sample of 172 firms whose 1999 annual reports appear on the Connect 4 annual report database and which have reported intangible assets identified through the 17th edition of Huntleys' Shareholder. 

SECTION TWO 


\title{
7 Changing structure of Chinese enterprises and human resource management practices in China
}

\author{
Shuming Zhao*
}

\subsection{Introduction}

Economic reform and opening up to the outside world have made profound changes to the economic and social development of China. The most dramatic changes are in two areas. One is the change in the economic system. China has transformed its economic system from a highly centralized, planned economy to a market economy. Though people hold different views on whether or not China has set up a complete market economic system, the transformation has been profound and irreversible. Moreover, it has been necessary to speed up the reform process, especially since China's entry into the World Trade Organisation (WTO). The other change has been in the ownership structure of enterprises.

China began its open-door policy and economic reform in 1978. The reform started in rural areas (with farmers signing contracts with government for production) and was later introduced in industries (with managers signing contracts with the government). Deng Xiaoping's famous tour of Southern China in 1992 accelerated the pace of economic reform. The continuation of economic reform gained support from China's tenth Five-Year Plan (20022005), and was approved at the Ninth National People's Congress (NPC) in 2001. The sixteenth Party Congress in 2002 introduced a strategic plan to build a high-level consumption-oriented society, to deepen the reform of state-owned enterprises (SOEs), to strengthen the operation of the market, to further the open-door policy, to accelerate the development of science and technology and to reduce corruption over the next few years. All of this indicates that China's reforms are entering into a new period.

Figure 7.1 shows China's economic growth over the past 24 years, indicating that China's average annual growth rate in GDP from 1978 to 2002 was 8 per cent, much higher than the world average of 3 per cent. 


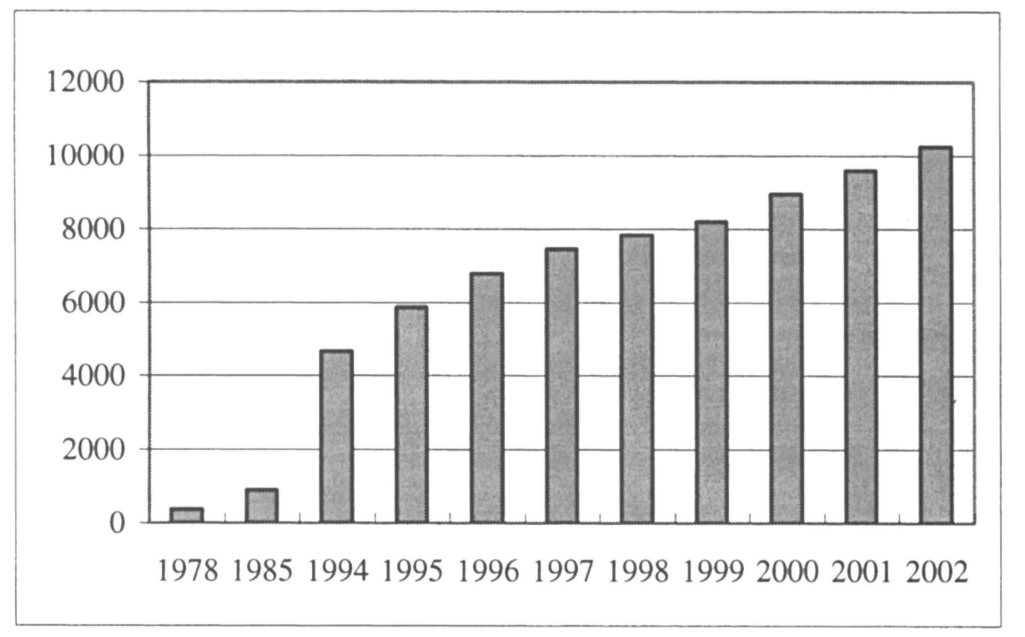

Figure 7.1 China economic growth after 1978 reform (GDP: billion RMB )

Other data also indicate that Chinese society has witnessed extensive development. Foreign exchange reserves totaled US $\$ 280$ billion by the end of 2002. In the same year, the total volume of imports and exports reached US $\$ 600.79$ billion, consisting of US\$325.57 billion in exports and US\$295.22 billion in imports, a rise of 22.3 per cent and 21.2 per cent respectively from their 2001 levels. Moreover, life expectancy has increased from 35 years, prior to the founding of New China in 1949, to 71.4 years in 2003.

China's economy is expected to continue to grow despite the effect of SARS in 2003. The latest data show that in the first quarter of 2003, China's GDP reached 2356.16 billion RMB, an increase of 9.9 per cent from the same quarter in 2002. And from January to May 2003, investment in China reached 1057.78 billion RMB, an increase of 31.7 per cent from 2002. It should not be difficult to reach the growth targets of investment (16 per cent) and GDP (7.9-8.2 per cent) for 2003.

\subsection{The history of personnel management in China}

Since economic reform began in China in 1978, several changes have taken place in human resource management. Before 1978 China had for decades operated a highly centralized planned economy. The same is true for the personnel management system. College graduates were assigned jobs. Companies and other organizations had to apply for personnel quotas from the government personnel department. Personnel management practices are described in Table 7.1. 
The characteristics of personnel management immediately before 1978 were based on the "three irons" policy. The "three irons" practices can be described as follows:

a. "Iron armchair", which refers to the management of executives and technicians under a permanent job system. Once a person was recruited, he or she would be entitled to hold the position for his or her entire life.

b. "Iron rice-bowl", which refers to the system of employment that created boundaries between "cadres" and "workers". A lifelong guarantee of a cadre's position, and the policy that cadres could be promoted but never demoted, led to a surplus of unproductive personnel.

c. "Iron wages", which describes the wage distribution system. In the highly centralized planned economic system, the state played an authoritative role in the compensation system of enterprises. Evenly distributed pay had little to do with profits and individual performance.

Since the start of economic reform in 1978, China began changing the personnel management system, especially after 1994 when the market economic system was officially adopted. There are two main reasons for the changes. First, it was necessary to change the personnel management system along with the establishment of the market system. Second, the open door policy attracted many multinational firms to invest in China, and Chinese enterprises faced fierce competition from multinational corporations in attracting and keeping high quality personnel. Table 7.2 describes the process of the change since the economic reform in 1978.

Table 7.1 Characteristics of personnel management before 1978

\begin{tabular}{|c|c|c|}
\hline Year & $\begin{array}{l}\text { Stage of personnel } \\
\text { management }\end{array}$ & Characteristics \\
\hline $\begin{array}{l}1949- \\
1952\end{array}$ & Preliminary Stage & $\begin{array}{l}\text { Fixed employment; state monopoly of } \\
\text { recruitment and labor allocation }\end{array}$ \\
\hline $\begin{array}{l}1952- \\
1957\end{array}$ & Beginning Stage & $\begin{array}{l}\text { Soviet management model with authoritarian } \\
\text { leadership; piece rate wages; merit-oriented } \\
\text { payment }\end{array}$ \\
\hline $\begin{array}{l}1957- \\
1966\end{array}$ & Development Stage & $\begin{array}{l}\text { Chief leader responsibility system; committees } \\
\text { with employee delegation; democratic } \\
\text { management with employee participation }\end{array}$ \\
\hline $\begin{array}{l}1966- \\
1977\end{array}$ & Stagnation Stage & "Three irons" policy strengthened \\
\hline
\end{tabular}

Source: Zhao (1998). 
Table 7.2 The development of the personnel system in China since the early $1980 \mathrm{~s}$

\begin{tabular}{llll}
\hline $\begin{array}{l}\text { Time } \\
\text { and } \\
\text { period }\end{array}$ & Stage & Characteristics & Traits \\
\hline $\begin{array}{l}\text { Early } \\
1980 \text { s to } \\
\text { mid } \\
1980 \text { s }\end{array}$ & $\begin{array}{l}\text { Exploration } \\
\text { Stage }\end{array}$ & $\begin{array}{l}\text { Reform of recruitment } \\
\text { methods to enlarge the pool } \\
\text { of candidates to include the } \\
\text { entire population; } \\
\text { strengthening of skill } \\
\text { training }\end{array}$ & $\begin{array}{l}\text { Decentralization of labor } \\
\text { relations and employment }\end{array}$ \\
$\begin{array}{l}\text { Mid to } \\
\text { late }\end{array}$ & $\begin{array}{l}\text { Break-through } \\
\text { stage }\end{array}$ & $\begin{array}{l}\text { Use of contracts } \\
\text { stage }\end{array}$ & $\begin{array}{l}\text { Enterprises become main } \\
\text { agency of employment; } \\
\text { employers and employees } \\
\text { can make mutual } \\
\text { employment decisions; } \\
\text { labor relations determined } \\
\text { through contracts }\end{array}$ \\
$\begin{array}{l}\text { Early } \\
1990 \text { s to } \\
\text { present }\end{array}$ & $\begin{array}{l}\text { Development } \\
\text { stage }\end{array}$ & $\begin{array}{l}\text { Abolishment of “3 irons" } \\
\text { policy; use of employment } \\
\text { contracts expanded to } \\
\text { include all employees } \\
\text { according to “labor law"; } \\
\text { appropriate macro-level } \\
\text { reforms }\end{array}$ & $\begin{array}{l}\text { Transfer to human resource } \\
\text { management system }\end{array}$ \\
\hline
\end{tabular}

Source: Zhao (1998).

The main characteristics of human resource management in China after the 1978 reforms can be described as follows (Zhao 2001):

a. The key human resource management transition in China was the shift from a political and administrative relationship to an economic relationship between government and enterprise.

b. The highly centralized labor allocation system shifted to "two-way" selection.

c. The fixed wage system shifted to an enterprise-determined compensation package.

d. The centralized control wage system failed to play an effective role within enterprises, and led to the existence of "low salary, low price".

e. The central government relaxed ceilings on executive pay for SOEs.

f. Competition for talent has increased since China's entry into the WTO in December 2001. 


\subsection{Changes in the structure of enterprise ownership}

The Fifteenth Party Congress, which was in session in Beijing in 1997, introduced the policy that mixed ownership forms should coexist with SOEs. Since that announcement, the forms and ownership structure of Chinese enterprises have changed a great deal. We can see from Tables 7.3 and 7.4 the changes in the forms and ownership structure of enterprises in China from 1996 to 2001 .

Table 7.3 Number of corporations and ownership structure of enterprises in China (December 31, 1996)

\begin{tabular}{l|l|r}
\hline & Corporation (10 thousand) & $(\%)$ \\
\hline Total & $\mathbf{2 6 2 . 8}$ & $\mathbf{1 0 0 . 0}$ \\
State-owned companies & 44.2 & 16.8 \\
Collective companies & 150.1 & 57.1 \\
Private companies & 44.3 & 16.9 \\
United companies & 4.4 & 1.7 \\
Share companies & 7.2 & 2.7 \\
Foreign-invested and Hong Kong, & 11.1 & 4.2 \\
Macau, Taiwan-invested companies & & \\
Others & 1.5 & 0.6 \\
\hline
\end{tabular}

Source: SSB (1998).

Table 7.4 Number of corporations, ownership structure, number of employees and percentage of employees of each type in firm (December 31, 2001)

\begin{tabular}{|c|c|c|c|c|}
\hline & $\begin{array}{l}\text { Corporation } \\
(10 \text { thousand ) }\end{array}$ & $\%$ & $\begin{array}{l}\text { Employees } \\
\text { (10 thousand) }\end{array}$ & $\%$ \\
\hline Total & 302.6 & 100.0 & 16502.2 & 100.0 \\
\hline State-owned companies & 36.9 & 12.2 & 5056.8 & 30.6 \\
\hline $\begin{array}{l}\text { Collectively owned } \\
\text { companies }\end{array}$ & 85.8 & 28.3 & 3763.1 & 22.8 \\
\hline Private companies & 132.3 & 43.7 & 3170.3 & 19.2 \\
\hline Share companies & 30.0 & 9.9 & 2746.6 & 16.6 \\
\hline Foreign-invested companies & 5.7 & 1.9 & 644.0 & 3.9 \\
\hline $\begin{array}{l}\text { Hong Kong, Macau, and } \\
\text { Taiwan-invested companies }\end{array}$ & 8.2 & 2.7 & 997.4 & 6.1 \\
\hline Others & 3.7 & 1.3 & 124.0 & 0.8 \\
\hline
\end{tabular}

Source: SSB (2003b). 
The present situation of Chinese enterprises can be described as follows:

a. State-owned enterprises are still the pillar of the Chinese national economy, though the number of SOEs has decreased and the ownership structure has changed. From January to May 2003, SOEs accounted for 52 per cent of the total output value in the whole country (SSB 2003a). State-owned or statecontrolled large enterprises still monopolized some industries, such as telecommunications, oil and petroleum. It seems that China's SOEs will continue to play a leading role in the national economy in the coming years.

b. A modern enterprise system is being set up gradually. Before the introduction of market reforms, Chinese enterprises were not real corporations; rather, they resembled workshops of a large factory. The Chinese government had controlled the production decisions of enterprises since 1949. What to produce, how many products to produce, to whom products were to be sold and the pricing of the products were all decided by government. Sometimes the government interfered directly in the daily operations of business. With the establishment of the market economic system and the deepening of the economic reform, Chinese enterprises gradually gained autonomy, and faced market competition directly.

c. Mixed ownership firms coexist with privately owned enterprises, and both ownership forms have developed quickly. From Figure 7.2, we can see clearly that the number of private enterprises has increased very fast in recent years. Currently, one-third of the employees in urban areas are working for private enterprises. And private enterprises make up more than 30 per cent of the country's gross domestic product. In Zhejiang Province, private enterprises have increased to more than 200,000. At present the largest source of taxation revenue in Zhejiang comes from private businesses (People's Daily 2003b).

d. The number of foreign-invested enterprises has been increasing annually. Foreign direct investment (FDI) in China soared by 48.15 per cent (on an annualized basis) to US\$23.271 billion in the first five months of 2003, according to the latest statistics from the Ministry of Commerce (MOC). A total of 439,371 foreign and overseas-funded enterprises have been set up since China adopted its policy of economic reform and opening up in 1978 (Xinhua News Agency 2003).

e. Many manufacturing enterprises have been merged. Notable instances are the five mergers of the ten national SOEs under the supervision of the newly established state-owned Assets Supervision and Administration Commission (SASAC). China Coal Construction Group merged with China Coal Energy Co.; China Scientific Instruments I\&E Co. merged with China Biotech Group; China Food-Fermentation Industrial Institute merged with China Light Industry Group; China Crude Drugs Group merged with China 


\section{Shuming Zhao}

Medicinal Group; and China Huaqing Co. merged with China Art \& Craft Co. (CCTV 2 2003).

There are still some problems that have hindered the development of Chinese enterprises during the transition period.

First, private enterprises have problems in getting loans from banks. Many private enterprises have entered the new high-tech sectors, and obtaining loans has been particularly problematic for them. Other sources of financing for private firms are also limited. There were only 139 private companies listed on China's stock markets at the end of 2002, accounting for 11.8 per cent of all listed companies (People's Daily 2003b).

Second, the government still carries out some enterprise functions, though a modern enterprise system has been gradually set up. Because of the long duration of the highly centralized planned economy, governments cannot transfer their responsibilities immediately. And enterprises, especially SOEs, cannot get rid of the old habits that follow from the government's administration. Enterprises need time to adjust.

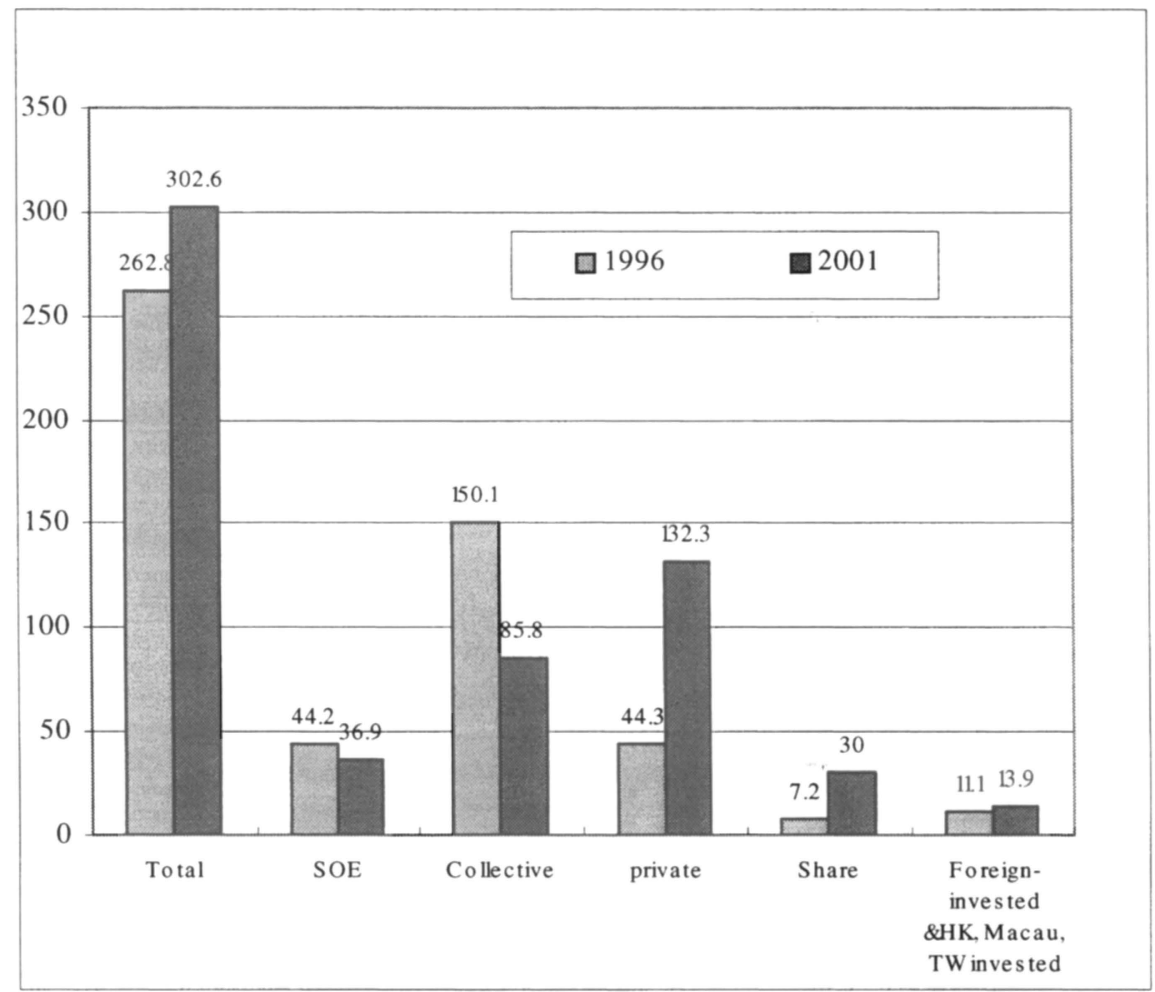

Figure 7.2 A comparison of different forms of corporations in China (10 thousand)

Source: SSB (1998, 2003b). 
Third, China has recently issued relevant laws and regulations on corporate governance, such as the Law for the Promotion of Small \& Medium-sized Enterprises, which came into operation on January 1, 2003. The legal system is still imperfect, however, and the legal system for protecting private property remains very weak. A report to China's People's Political Consultative Committee from the All-China Federation of Industry and Commerce recently indicated that the lack of effective legal protection is a major problem in protecting both private property and property rights. This hinders the development of private enterprises.

\subsection{Recent challenges to human resource management in China}

\subsubsection{Recent developments}

Since the start of economic reform, China's personnel system (under the highly centralized planned economic system) has been changed into human resource management under the market economy. Many changes have been taking place in recent years because of the restructuring of SOEs and the changing ownership structure. Some of the major recent changes are as follows.

\section{Residency card}

Generally speaking, from the 1950s until the 1990s Chinese citizens were divided into two categories in terms of residency registration (hukou). These two categories were agricultural residence (nongye hukou) and non-agricultural residence (fei nongye hukou) or urban residence (chengshi hukou). Residents of these different constituencies received very different treatment in employment, insurance and so on. If someone held an agricultural residency card, he or she could not work or live in the city unless he or she received a bachelor's degree or above, served in the army or was promoted to cadre status. Under these circumstances an individual could change his or her status from agricultural resident to urban resident. Restrictions on mobility became a serious problem for companies wishing to recruit people from rural areas or to hire talent from other cities.

From 1993, China started to reform the residency registration system. The goal of this reform was to implement the same citizen registration in the whole country. In late 2001, several provinces (such as Jilin, Hunan, Guangdong, Fujian and Liaoning) abolished residential divisions. In 2002, the new residence registration reform began. Chinese citizens who have a place to live in the city, hold a job and receive a stable income may now apply for their regular residential status from the local police office. Early in 2003, Jiangsu Provincial Government issued a document stating that all residents in Jiangsu Province 


\section{Shuming Zhao}

would have the same equal residential status from 1 May 2003. This will help talent to move to the places where the market needs it (Xinhua 2002).

\section{Personal file or record}

The personal file (dang'an), which a citizen is not allowed to see, records an individual's education and work experience, including high-school and university transcripts, reviews and comments from former and present employers. At present, state-owned companies have the right to keep employees' personal records. Employees in other companies (such as overseas-funded firms) have to pay authorized human resources agencies, such as personnel exchange centers, 20 RMB (about US\$2.4) a month per employee for keeping their files. This is a system that a growing number of locals say is out of step with China's shift to a market economy.

Companies cannot sign a contract with a new employee without first obtaining his or her file. The files are required for people to move from one place to another or to move from one organization to another. However, the importance of personal files is declining. Some provincial and municipal governments have set up new personal files and ignored the old ones in order to help local firms and other organizations to attract more talent.

\section{Social security system}

During the State's ninth Five-Year Plan period (from 1996 to 2000), the State Council issued a series of regulations about social insurance. With these regulations, a new social security system has been established. At present, China's new social security consists of life insurance, unemployment insurance, industrial injury insurance, medical insurance and housing subsidies. The latest survey shows that the current social security policy has problems, such as not enough money for all these different kinds of insurance. One of the important tasks of the reform of the Chinese social security system now is to expand the coverage rate of social insurance. And to achieve the reform, a greater amount of money to pay the conversion cost is needed. The issue of how to raise funds in order to pay for this is an extremely important problem.

\section{Housing}

In the past, under the highly centralized planned economy, the government allocated money to all public organizations to build apartments, and enterprises distributed housing to their employees nearly for free. As a result, the government had a heavy financial burden, the living conditions of the residents were poor and an urban real estate market was unable to develop. Reform of the housing policy was essential, and the process began in the late 1990s. The housing policy has now been reformed in many aspects, including the following: 
a. Individuals are allowed to purchase their houses.

b. A second-hand housing market has been introduced.

c. A multi-tier system of housing has been set up. People with high incomes are permitted to buy apartments at market prices and can sell and buy housing on the market. People with low and middle incomes can purchase economic and functional housing. People with the lowest income can apply for low-rent housing that is managed directly by the government's housing department.

\subsubsection{The present situation of Chinese human resources management}

\section{Recruiting}

Since China's Labor Law became effective on 1 January 1995, the contract employment system has been widely used in Chinese enterprises and the former system of assigning jobs to each individual has been abolished. Enterprises have the right to recruit and select their employees from the labor market or personnel exchange centers all over China. In early 2003, the end of "jobs-for-life" for the 30 million public employees was announced, and the reform of China's public institutions was launched. This reform has been one of the biggest restructuring efforts in the field of employment in China and as such is a vital part of the country's modernization program. Public institutions have begun the practice of signing contracts with individuals instead of offering permanent jobs. The reform of human resources in public institutions will be completed within five years, by 2008 , and at that time the contract employment system will be extended to other enterprises.

One feature of human resources in China is that there are abundant laborers, but there is a scarcity of skilled labor. China is a large country with a population of 1.3 billion people. However, most of the people have not received a high level of education. In 2000, the average education of Chinese workers was only 7.42 years, about five years less than in the United States (Ministry of Education 2003). Closing this gap is a difficult and important task for developing human resources in China. Foreign-invested corporations offer more attractive compensation and opportunities for further training than do most Chinese enterprises. Young people, especially those who have received a good education, often prefer to work in foreign-invested firms.

\section{Training}

Training is a rather random business in most Chinese SOEs. Most Chinese enterprises have been aware of the importance of training, but systematic training structures have not been encouraged. Training is not connected with corporate strategy or with employees' career development. Some enterprises do 


\section{Shuming Zhao}

not know the real purpose of training, and therefore training becomes simply a formality.

Training plays an important motivational role for top management and senior staff. Top managers pay more attention to training opportunities than others do, because they want to improve themselves. Some enterprises that have set up human resource management systems have introduced training as a special benefit for high-level staff in order to attract talented people.

Technical training is receiving more emphasis as the shortage of technical workers is becoming a serious problem in China. In particular, a lack of senior technical workers is one of the most urgent needs in Shanghai, China's biggest city.

\section{Performance evaluation}

Performance evaluation is widely used in China nowadays. But it is not effective without motivation and supervision. There are no systematic performance evaluation systems. As a result, performance evaluation does not work well in most Chinese enterprises. Human resource management scholars and practitioners have been trying their best to develop performance evaluation systems that fit Chinese enterprises. Performance evaluation is highly regarded by employees because it is connected to their incomes.

\section{Compensation system}

Compensation reform in Chinese enterprises has been introduced gradually since the 1990s. For example, the Shenzhen Municipal Government set up a regulation on compensation for the top management of Shenzhen City SOEs in the late 1990s and renewed it in early 2003. Beginning from 2003 compensation for managers of SOEs in Shenzhen City has three components: basic salary, performance reward, and annual bonus. The basic salaries for managers at three different levels of SOEs are: 120,000 RMB for first-level enterprise managers, $108,000 \mathrm{RMB}$ for second level and 96,000 RMB for the third level. If the firm performs well in a year, managers can receive an annual bonus of as much as 480,000 RMB (China Youth Daily 2003).

According to a recent survey, compensation for key positions in foreigninvested firms in Guangzhou is increasing (see Table 7.5). It is reported that 65.4 per cent of the foreign-invested firms have a fixed salary increase system, averaging about 9.1 per cent more than the previous year. Altogether, 93.6 per cent of the foreign-invested firms have an annual increase system. In the 20022003 fiscal year the average salary increase in foreign-invested firms in Guangzhou was about 6.1 per cent. For benefits, employees have 18 to 31 days of paid leave for visiting parents or family, in addition to legal holidays. Most foreign-invested firms provide free meals during their workdays and subsidies for housing; 78.8 per cent of the firms have allocated housing funds. Additional measures that foreign-invested firms have taken are salary increases, special 
training and development programs, and promotion opportunities. Annual average training expenditure for each employee is about 9000 RMB. Altogether 93.5 per cent of the foreign-invested firms have an annual budget of about 5 per cent from the total sale revenue for annual training expenditure, of which the inhouse training budget is about $7896 \mathrm{RMB}$ per person per year and the out-ofcompany training budget is about $1026 \mathrm{RMB}$ per person per year. In addition, 80.6 per cent of the firms have 13-month salaries; 87.5 per cent have sales bonuses; 37.5 per cent of firms give annual sales bonuses; 31.3 per cent give sales rewards quarterly; and 62.5 per cent give sales rewards monthly (Guangzhou Topper Human Resource Consultants 2003).

Tables 7.5 to 7.9 present the results of a survey carried out by Guangzhou Topper Human Resource Consultants in 2003 on compensation and stock options for senior management and independent directors in the top 20 Chinese listed firms. From these tables one can see the extent to which executive compensation in large listed companies is determined by market forces. This reflects major changes in the compensation structure for management in top Chinese firms compared with the past, with stock options (tied to firm performance) having only been introduced as one of the components of the compensation system in China in recent years.

Table 7.5 Survey results of salary for key positions in foreign-invested firms in Guangzhou (2002-2003, RMB)

\begin{tabular}{lccc}
\hline Position & Lowest salary & Highest salary & Average \\
\hline General Manager & 178,629 & $1,156,498$ & 476,463 \\
Deputy General Manager & 187,951 & $1,046,420$ & 413,462 \\
Marketing Manager & 71,080 & 683,566 & 312,609 \\
Human Resources Manager & 113,202 & 620,983 & 212,582 \\
Financial Manager & 81,069 & 362,271 & 238,737 \\
Manufacturing Manager & 36,327 & 325,095 & 146,271 \\
Technology Management & 42,192 & 288,019 & 179,458 \\
\hline
\end{tabular}

Source: Guangzhou Topper Human Resource Consultants (2003). 
118 Shuming Zhao

Table 7.6 Compensation for top management in top 20 Chinese listed firms 2003

\begin{tabular}{|c|c|c|c|c|}
\hline Rank & $\begin{array}{l}\text { Annual } \\
\text { salary } \\
(10 \\
\text { thousand } \\
\text { RMB) }\end{array}$ & Name of company & Location & Industry \\
\hline 1 & 750.00 & $\begin{array}{l}\text { Guangdong Kelon Electrical Holding } \\
\text { Co.Ltd }\end{array}$ & Guangdong & Manufacturing \\
\hline 2 & 127.11 & Fuyao Class Co.Ltd & Fujian & Manufacturing \\
\hline 3 & 123.33 & Ufsoft Co. Ltd & Beijing & IT \\
\hline 4 & 100.00 & $\begin{array}{l}\text { Qindao Doublestar Shoe Manufacturing } \\
\text { Co. Ltd }\end{array}$ & Shandong & Manufacturing \\
\hline 5 & 100.00 & Lu Thai Textile Co. Ltd & Shandong & Manufacturing \\
\hline 6 & 100.00 & Dalian Chuangye Co. Ltd & Liaoning & Manufacturing \\
\hline 7 & 93.00 & China World Trade Center & Beijing & Service \\
\hline 8 & 86.00 & Jiangsu Little Swan Co. Ltd & Jiangsu & Manufacturing \\
\hline 9 & 75.00 & Zhejiang Guangxia Co. Ltd & Zhejiang & Construction \\
\hline 10 & 70.00 & $\begin{array}{l}\text { Xinxing Ductile Iron Pipes (Group) Co. } \\
\text { Ltd }\end{array}$ & Hebei & Manufacturing \\
\hline 11 & 61.00 & China Youth Travel Co. Ltd & Beijing & $\begin{array}{l}\text { Multiple } \\
\text { businesses }\end{array}$ \\
\hline 12 & 60.00 & $\begin{array}{l}\text { China International Marine Containers } \\
\text { (Group) Co. Ltd }\end{array}$ & Guangdong & Manufacturing \\
\hline 13 & 60.00 & Powerise Co. Ltd & Guangdong & IT \\
\hline 14 & 58.33 & Dajiang Co. Ltd & Shanghai & Manufacturing \\
\hline 15 & 56.16 & Zte Co. Ltd & Guangdong & IT \\
\hline 16 & 55.00 & Midea Co. Ltd & Guangdong & Manufacturing \\
\hline 17 & 55.00 & $\begin{array}{l}\text { Inner Mongolia North Hauler Joint Stock } \\
\text { Limited Company }\end{array}$ & $\begin{array}{l}\text { Inner } \\
\text { Mongolia }\end{array}$ & Manufacturing \\
\hline 18 & 55.00 & Nantian Information Co. Ltd & Yunnan & IT \\
\hline 19 & 52.50 & China Vanke Co. Ltd & Guangdong & Real estate \\
\hline 20 & 51.75 & Huagong Tech Co. Ltd & Hubei & Manufacturing \\
\hline
\end{tabular}

Source: Guangzhou Topper Human Resource Consultants (2003). 


\begin{tabular}{|c|c|c|c|}
\hline 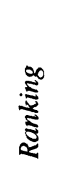 & 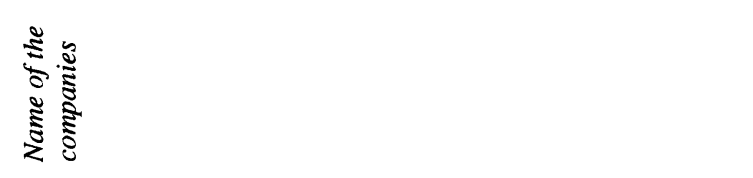 & $\begin{array}{l}\tilde{\Xi} \\
\mathbb{\Xi} \\
\Xi\end{array}$ & 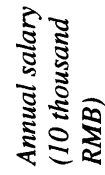 \\
\hline 1 & $\begin{array}{l}\text { Tianjin Capital Environmental Protection Company } \\
\text { Limited }\end{array}$ & Tianjin & 26.50 \\
\hline 2 & Baoshan Iron and Steel Co. Ltd & Shanghai & 20.00 \\
\hline 3 & Shenzhen Expressway Company Limited & Guangdong & 12.27 \\
\hline 4 & Shenzhen Neptunus Bioengineering Co. Ltd & Guangdong & 10.00 \\
\hline 5 & Guangzhou Pharmaceutical Company Limited & Guangdong & 9.52 \\
\hline 6 & China International Marine Containers ( Group ) Co. Ltd & Guangdong & 8.00 \\
\hline 7 & Tsinghua Tongfang Co. Ltd & Beijing & 8.00 \\
\hline 8 & Hainan Airlines Co. Ltd & Hainan & 8.00 \\
\hline 9 & Huafang Co. Ltd & Shandong & 8.00 \\
\hline 10 & Yanzhou Coal Mining Co. Ltd & Shandong & 7.00 \\
\hline 11 & Guangzhou Shipyard International Company Limited & Guangdong & 6.54 \\
\hline 12 & China Fangda Group Co. Ltd & Guangdong & 6.00 \\
\hline 13 & Shenzhen Yan Tian Port Holdings Co. Ltd & Guangdong & 6.00 \\
\hline 14 & $\begin{array}{l}\text { Hunan Henghong Science And Technology Develop Co. } \\
\text { Ltd }\end{array}$ & Hunan & 6.00 \\
\hline 15 & Wuhan Kaidi Electric Power Co. Ltd & Hubei & 6.00 \\
\hline 16 & Henan Lianhua Gourmet Powder Co. Ltd & Henan & 6.00 \\
\hline 17 & Gansu Ronghua Industry Group Co. Ltd & Gansu & 6.00 \\
\hline 18 & Shenzhen Taitai Pharmaceutical Company Limited & Guangdong & 6.00 \\
\hline 19 & Zhejiang Xinan Chemical Industrial Group Co. Ltd & Zhejiang & 6.00 \\
\hline 20 & Hualian Supermarket Co. Ltd & Shanghai & 6.00 \\
\hline
\end{tabular}

Source: Guangzhou Topper Human Resource Consultants (2003). 


\section{Shuming Zhao}

Table 7.8 Stock options for the top 20 chairmen of the board in Chinese listed firms 2003

\begin{tabular}{|c|c|c|c|c|c|c|}
\hline 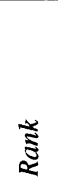 & 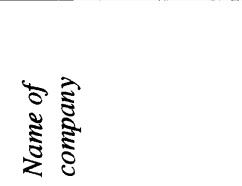 & 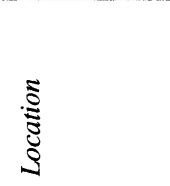 & $\frac{5}{3} \cdot \frac{\sqrt{3}}{3}$ & 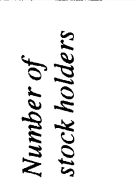 & 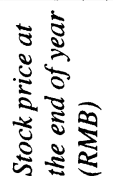 & 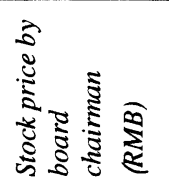 \\
\hline 1 & Orient Group & Heilongiiang & $\begin{array}{l}\text { Zhang } \\
\text { Hongwei }\end{array}$ & $2,813,899$ & 7.77 & $21,863,995.23$ \\
\hline 2 & $\begin{array}{l}\text { Ningbo Yunsheng } \\
\text { Co. Ltd }\end{array}$ & Zhejiang & $\begin{array}{l}\text { Zhu } \\
\text { Yunde }\end{array}$ & 891,000 & 24.27 & $21,624,570.00$ \\
\hline 3 & $\begin{array}{l}\text { Zhejiang Guangsha } \\
\text { Co. Ltd }\end{array}$ & Zhejiang & $\begin{array}{l}\text { Lou } \\
\text { Zhongfu }\end{array}$ & $1,437,345$ & 9.72 & $13,970,993.40$ \\
\hline 4 & $\begin{array}{l}\text { Wanxiang } \\
\text { Qianchao Co. Ltd }\end{array}$ & Zhejiang & $\begin{array}{l}\text { Lu } \\
\text { Guanqiu }\end{array}$ & 679,031 & 10.58 & $7,184,147.98$ \\
\hline 5 & Midea Co. Ltd & Guangdong & $\begin{array}{l}\text { He } \\
\text { Hengjian }\end{array}$ & 559,859 & 10.12 & $5,665,773.08$ \\
\hline 6 & $\begin{array}{l}\text { Dongfang } \\
\text { Electronics Co. Ltd }\end{array}$ & Shandong & $\begin{array}{l}\text { Shui } \\
\text { Yuanbo }\end{array}$ & 739,200 & 6.04 & $4,464,768.00$ \\
\hline 7 & $\begin{array}{l}\text { Zhejiang Eastern } \\
\text { Co. Ltd }\end{array}$ & Zhejiang & $\begin{array}{l}\text { Liu } \\
\text { Linsheng }\end{array}$ & 200,448 & 21.12 & $4,233,461.76$ \\
\hline 8 & Youngor Co. Ltd & Zhejiang & $\begin{array}{l}\text { Li } \\
\text { Rucheng }\end{array}$ & 373,152 & 11.14 & $4,156,913.28$ \\
\hline 9 & $\begin{array}{l}\text { Shandong Lubei } \\
\text { Chemical Co. Ltd }\end{array}$ & Shandong & $\begin{array}{l}\text { Feng } \\
\text { Jiutian }\end{array}$ & 309,777 & 13.15 & $4,073,567.55$ \\
\hline 10 & $\begin{array}{l}\text { Shenzhen } \\
\text { Agricultural } \\
\text { Products Ltd }\end{array}$ & Guangdong & $\begin{array}{l}\text { Lin } \\
\text { Jiahong }\end{array}$ & 308,283 & 13.16 & $4,057,004.28$ \\
\hline 11 & $\begin{array}{l}\text { Guangdong Meiyan } \\
\text { Co. Ltd }\end{array}$ & Guangdong & $\begin{array}{l}\text { Yang } \\
\text { Qinhuan }\end{array}$ & 717,183 & 4.81 & $3,449,650.23$ \\
\hline 12 & Neusoft Co. Ltd. & Liaoning & Liu Jiren & 156,130 & 21.34 & $3,331,814.20$ \\
\hline 13 & $\begin{array}{l}\text { Liaoning Cheng Da } \\
\text { Enterprises Co. Ltd. }\end{array}$ & Liaoning & $\begin{array}{l}\text { Shang } \\
\text { Shuzi }\end{array}$ & 222,300 & 14.58 & $3,241,134.00$ \\
\hline 14 & $\begin{array}{l}\text { Jiangsu Etern Co. } \\
\text { Ltd }\end{array}$ & Jiangsu & $\begin{array}{l}\text { Gu } \\
\text { Yunkui }\end{array}$ & 200,000 & 12.62 & $2,524,000.00$ \\
\hline 15 & $\begin{array}{l}\text { Shenzhen Kaifa } \\
\text { Technology Co. Ltd }\end{array}$ & Guangdong & Wang Zhi & 214,207 & 11.74 & $2,514,790.18$ \\
\hline 16 & Fiyta Co. Ltd & Guangdong & $\begin{array}{l}\text { Li } \\
\text { Zhizheng }\end{array}$ & 124,416 & 17.83 & $2,218,337.28$ \\
\hline 17 & Zhongda Co, Ltd & Zhejiang & $\begin{array}{l}\text { Cheng } \\
\text { Jida }\end{array}$ & 190,125 & 10.00 & $1,901,250.00$ \\
\hline 18 & $\begin{array}{l}\text { China Vanke Co. } \\
\text { Ltd }\end{array}$ & Guangdong & Wang Shi & 139,559 & 13.35 & $1,863,112.65$ \\
\hline 19 & $\begin{array}{l}\text { Guangzhou } \\
\text { Development } \\
\text { Industry (Holding) } \\
\text { Co. Ltd }\end{array}$ & Guangdong & $\begin{array}{l}\text { Yang } \\
\text { Dandi }\end{array}$ & 112,320 & 15.31 & $1,719,619.20$ \\
\hline 20 & Yatai Co. Ltd & Jilin & $\begin{array}{l}\text { Song } \\
\text { Shanglong }\end{array}$ & 232,402 & 7.16 & $1,663,998.32$ \\
\hline
\end{tabular}

Source: Guangzhou Topper Human Resource Consultants (2003). 
Table 7.9 Stock options for the top 20 general managers in Chinese listed firms 2003

\begin{tabular}{|c|c|c|c|c|c|c|}
\hline 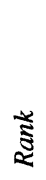 & 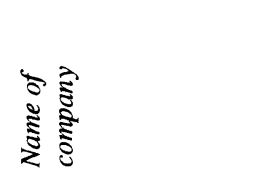 & 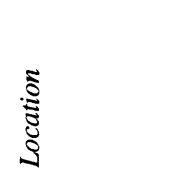 & 各 & 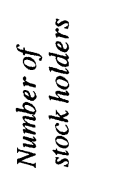 & 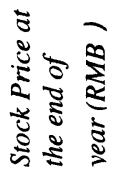 & 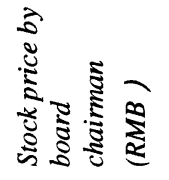 \\
\hline 1 & Orient Group & Heilongjiang & An Ying & $1,707,797$ & 7.77 & $13,269,582.69$ \\
\hline 2 & $\begin{array}{l}\text { Shenzhen Kaifa } \\
\text { Technology Co. Ltd }\end{array}$ & Guangdong & $\begin{array}{l}\text { Tan } \\
\text { Zhiwen }\end{array}$ & 714,025 & 11.74 & $8,382,653.50$ \\
\hline 3 & $\begin{array}{l}\text { Zhejiang Eastern Co. } \\
\text { Ltd }\end{array}$ & Zhejiang & $\begin{array}{l}\text { Wu } \\
\text { Jianhua }\end{array}$ & 190,426 & 21.12 & $4,021,797.12$ \\
\hline 4 & $\begin{array}{l}\text { Liaoning Cheng } \mathrm{Da} \\
\text { Enterprises Co..Ltd }\end{array}$ & Liaoning & $\begin{array}{l}\text { Zhang } \\
\text { Dezhong }\end{array}$ & 177,840 & 14.58 & $2,592,907.20$ \\
\hline 5 & $\begin{array}{l}\text { Ling Bo Fuda Co. } \\
\text { Ltd }\end{array}$ & Zhejiang & $\begin{array}{l}\text { Xu } \\
\text { Laiying }\end{array}$ & 211,954 & 11.64 & $2,467,144.56$ \\
\hline 6 & $\begin{array}{l}\text { Tsinghua Tongfang } \\
\text { Co. Ltd }\end{array}$ & Beijing & $\begin{array}{l}\text { Lu } \\
\text { Zhicheng }\end{array}$ & 103,623 & 20.17 & $2,090,075.91$ \\
\hline 7 & $\begin{array}{l}\text { China International } \\
\text { Marine Containers } \\
\text { (Group) Co. Ltd. }\end{array}$ & Zhejiang & $\begin{array}{l}\text { Mai } \\
\text { Boliang }\end{array}$ & 78,078 & 26.66 & $2,081,559.48$ \\
\hline 8 & $\begin{array}{l}\text { Jiangsu Sanmu } \\
\text { Group Co. }\end{array}$ & Jiangsu & $\begin{array}{l}\text { Cheng } \\
\text { Weihui }\end{array}$ & 164,454 & 12.60 & $2,072,120.40$ \\
\hline 9 & $\begin{array}{l}\text { Shanghai Haxin } \\
\text { Group Co. Ltd }\end{array}$ & Shanghai & $\begin{array}{l}\text { Yuan } \\
\text { Yonglin }\end{array}$ & 113,514 & 16.85 & $1,912,710.90$ \\
\hline 10 & Zte Co. Ltd & Guangdong & $\begin{array}{l}\text { Hou } \\
\text { Weigui }\end{array}$ & 72,000 & 23.46 & $1,689,120.00$ \\
\hline 11 & $\begin{array}{l}\text { Shengzhen } \\
\text { International Co. Ltd }\end{array}$ & Guangdong & $\begin{array}{l}\text { Song } \\
\text { Shenjun }\end{array}$ & 172,800 & 9.12 & $1,575,936.00$ \\
\hline 12 & $\begin{array}{l}\text { Xinjiang Tunhe Co. } \\
\text { Ltd }\end{array}$ & Xinjiang & $\begin{array}{l}\text { Zhang } \\
\text { Guo }\end{array}$ & 639,600 & 21.71 & $1,388,571.60$ \\
\hline 13 & $\begin{array}{l}\text { Guangdong Chunhui } \\
\text { Co. Ltd }\end{array}$ & Guangdong & Wu Jun & 144,000 & 9.07 & $1,306,080.00$ \\
\hline 14 & $\begin{array}{l}\text { Guangzhou } \\
\text { Development } \\
\text { Industry (Holding) } \\
\text { Co. Ltd }\end{array}$ & Guangdong & Liu Haitao & 78,200 & 15.31 & $1,197,242.00$ \\
\hline 15 & $\begin{array}{l}\text { Dongfang } \\
\text { Electronics Co. Ltd }\end{array}$ & Shandong & $\begin{array}{l}\text { Ding } \\
\text { Zhenghua }\end{array}$ & 184,019 & 6.04 & $1,111,474.76$ \\
\hline 16 & $\begin{array}{l}\text { Jiangsu Wujiang } \\
\text { delicacy Chemical } \\
\text { Co. Ltd }\end{array}$ & Jiangsu & $\begin{array}{l}\text { Yao } \\
\text { Jianlin }\end{array}$ & 68,400 & 16.02 & $1,095,768.00$ \\
\hline 17 & $\begin{array}{l}\text { Shanghai Jinling Co. } \\
\text { Ltd }\end{array}$ & Shanghai & Xu Weiwu & 130,127 & 7.24 & $942,119.48$ \\
\hline 18 & $\begin{array}{l}\text { Shandong Heibao } \\
\text { Co. Ltd }\end{array}$ & Shandong & $\begin{array}{l}\text { Shun } \\
\text { Xianyou }\end{array}$ & 117,000 & 7.89 & $923,130.00$ \\
\hline 19 & $\begin{array}{l}\text { Shandong Jiufa } \\
\text { Edible Fungus Co. } \\
\text { Ltd. }\end{array}$ & Shandong & $\begin{array}{l}\text { Wang } \\
\text { Hongqin }\end{array}$ & 49,920 & 17.45 & $871,104.00$ \\
\hline 20 & $\begin{array}{l}\text { Shenzhen Kangdar } \\
\text { Co. Ltd }\end{array}$ & Guangdong & Ou Xitao & 141,588 & 6.09 & $862,270.92$ \\
\hline
\end{tabular}




\subsubsection{Successful cases}

\section{$P \& G$ in China}

In 1988, P\&G founded the first joint venture in China, Guangzhou P\&G Co. Ltd. Today, P\&G has achieved great success in the Chinese market, setting a good example in human resource management for foreign-invested firms in China.

In order to attract the best college graduates, $P \& G$ in China took three measures to recruit the best staff:

a. Establishing P\&G scholarships at top Chinese universities.

b. Lecturing and giving presentations on the campuses.

c. Designing a competitive recruitment and selection program.

P\&G in China has become the most popular foreign company in Chinese universities and has attracted thousands of outstanding graduates.

The promotion system in $P \& G$ is designed to be fair to every employee. It includes internal promotion, international promotion, challenging career experience and management opportunities for local Chinese staff.

Training is used to invest in human resources and motivate employees. $P \& G$ provides all different kinds of training programs for its employees. All employees are encouraged to participate in lifelong learning and organization building.

P\&G's compensation system is designed in accordance with international standards. The market determines the group average level of compensation. The modern compensation structure includes salary, various welfare benefits, stock options and other methods, for rewarding performance. Profit sharing is also used to retain good employees.

\section{Haier Group}

The Haier Corporation was established in 1984 manufacturing only refrigerators. Over the past 20 years, the Haier Corporation has grown from one small factory into a large transnational company widely recognized in the world community. The Haier Group now manufactures a broad range of household electrical appliances in 86 categories with 13,000 specifications and exports products to more than 160 countries. Haier's global sales in 2002 totaled RMB71.1 billion, including overseas turnover of US $\$ 1$ billion.

Haier tries to build a fair, open, and just atmosphere for employees. There are four human resource development principles in Haier. First, the Human Resource Development Center studies corporate human resource management policies to tap employees' potential and motivate people. They have designed three kinds of career development program for all employees. One program is for people whose career path is in management; another is designed for professional personnel, and the third is designed for blue-collar workers. 
Second, management staff who are already in their positions are supervised and evaluated. Promotion is the result of competition. Third, managers should be trained at different departments at a lower level before being promoted to a higher position. And last, a small percentage of personnel are removed from their positions based on poor performance.

\subsection{Conclusion}

Many changes have taken place in Chinese enterprises since China started economic reform and opening up to the outside world in 1978, especially in recent years. The changing structure of Chinese enterprises has brought attention to some critical issues concerning human resource management. The purpose of this chapter was to outline some of the changes that have taken place in Chinese enterprises since China began its economic reforms and opening up to the outside world, and to describe the changing structure of human resource management in those enterprises. The chapter analyzes the present situation, discussing problems and challenges of Chinese enterprises and the main characteristics of human resource management in China, with brief reference to recruiting, training and development, performance evaluation, and compensation practices in two specific enterprises.

\section{Notes}

* This chapter is part of a research project supported by the National Natural Science Foundation of China, Project number: 70372036; Ministry of Education research project, 03JB630014; and Business Administration National Key Specialty of Nanjing University. 


\title{
8 The management of human resources in Shanghai
}

\author{
A case study of policy responses to \\ employment and unemployment in the \\ People's Republic of China
}

\author{
Grace O. M. Lee and Malcolm Warner
}

\subsection{Introduction}

The management of human resources - broadly conceived - in the People's Republic of China (henceforth to be referred to as China) was associated with a Soviet-style command economy and lifetime employment from 1949 (when Mao Zedong took power) until 1978 (when Deng Xiaoping's economic reforms were initially launched).

The Chinese worker in the 1950s saw the implementation of a 'jobs for life' and 'cradle to the grave' welfare policy for those working in the urban industrial state-owned enterprises (SOEs). This system was widely known in Chinese parlance as the 'iron rice-bowl' (tie fanwan) and the phrase became a widely used shorthand term for the management status quo amongst informed outsiders interested in what is happening in that country (see Child 1994). The system was partly derived from earlier Chinese Communist experience in the so-called 'liberated zones' during the war with Japan, as well as later, Soviet practice, but may in addition have had roots in Japanese precedents in occupied Manchuria and it is likely that there was a wide range of earlier influences that shaped the evolution of the 'iron rice-bowl'. It had become definitively embedded in industrial life and fully institutionalized by the mid-1950s. Labour market imbalances were to be addressed at the company level rather than in the open market. As with the Japanese labour market policy model, the emphasis was on the 'internal' labour market within the enterprise as opposed to the 'external' labour market outside the enterprise. It is an enterprise-centred and industrydriven form of labour market management. In this context, labour market policies may be considered as social protection, both in theory and in practice, and as intended as a form of employment protection (Abrahart and Verme 2001:60). Several writers (such as Walder 1986 or Warner 1995) have seen the 'iron rice-bowl' relationship as 'organizational dependency', and as an important theoretical support for their analysis, to which we will return later. The mindsets associated with this relationship became deep-rooted and difficult to modify or change. Even so, with the beginnings of the economic reforms, the guarantees of the 'iron rice-bowl' began to be eroded. 
But this only came about gradually in the reform period. The policy of jobs for life lingered on in the 1980s, and it was not until the 1990s that the "iron rice-bowl' began to be effectively replaced by a market-oriented set of labour and personnel reforms. The 'lifetime' employment system was generally believed by economics and management scholars to be associated with weak people-management and to reinforce factor-immobility and inefficiency (see Warner 1995, 1999 and 2000 on the background literature on this). The government acknowledged the existence of unemployment as a necessary temporary condition to facilitate and maximize the allocation of labour, and the government's role has become mainly to support the unemployed with income maintenance and training schemes so as to facilitate job seeking and placement. Managers were now allowed more autonomy to hire and fire, particularly in SOEs; decision-making was to become more decentralized in not only personnel but also marketing and purchasing domains. A reform-inspired workplace practice adopted from the mid-1980s onwards had been the implementation of 'labour contracts'. By defining the length of the contract, the period of employment became sharply delineated and this displaced the previously enshrined practice of permanent 'lifetime employment'. In theory, workers in China had since the 1950s been the 'masters of the country' (guojia zhuren), with the bad old days of job insecurity a bygone feature; by definition, unemployment could not exist. The key question of the day was the 'right to work' (gongzuo quan) and 'full employment' (quanmin jiuye).

Unemployment, sanitized in the phrase 'waiting for work' (daiye), intertwined in turn with poverty, now poses such a major threat to both social stability and the rule of the Chinese Communist Party (CCP), however, that it demands an urgent policy response. This chapter begins with an examination of the issue of employment and unemployment in China, then moves on to explain the institutional changes that brought about the problem. We then discuss our research methodology. Shanghai will be taken as a case study to explore policy responses; in the next section a labour market model will be developed to discuss both active and passive labour market programmes in Shanghai. Despite the apparent success of the Shanghai model, its general applicability to other cities remains uncertain, particularly in view of China's entry to the World Trade Organisation (WTO), the subject of the discussion section that follows. The final section presents some conclusions.

\subsection{Employment and unemployment in China}

At the present time, China's billion and a quarter population and vast labour force, the largest in the world (see Warner 1995), puts human resources high on the agenda as far as the recent WTO entry (in late December 2001) is concerned. Many of the labour force of over 700 million are country-dwellers and still live in townships and villages. There has been until lately a strict 'one-child policy' in most of the People's Republic to restrain population numbers, as new citizens as well as existing ones have to be fed, housed and employed - no easy challenge. Half of the labour force work on the land, but it is estimated that over 


\section{Grace O. M. Lee and Malcolm Warner}

200 million of these are surplus to economic requirements. Already over 100 million are on the move, making their way into the towns as part of the 'floating' migrant population known as the mingong. Over a third of China's population live in urban areas. Those out of work in the towns were officially calculated at 3.5 per cent of the urban workforce in the late 1990s, but in reality this figure could be much higher, as we shall shortly see.

Shanghai, China's largest city, was no exception. Unemployment was officially unknown throughout the Maoist years. Jobs for life were de rigueur. The unemployment rate in Shanghai even by 2001 was officially seen as low as 4.3 per cent, in spite of the industrial restructuring that had taken place in that conurbation (Shanghai Statistical Bureau 2002). It is more than likely to be an underestimate. As Solinger has rightly pointed out, 'accurate data are hard to come by, since government statistics are murky and often presented in a way that suggest that the numbers are not all that large' (Solinger 2002: 304). The State Council's Development Research Centre issued a report that contradicts official figures for the current unemployment rate. In contrast to the very recent official rate of 4.5 per cent in China, the report indicates that the urban unemployment rate is already 10 per cent, and will rise to 15 per cent under the impact of World Trade Organisation entry. ${ }^{1}$ Politics has plagued the use of statistics from the beginning of the People's Republic. As long as high GDP growth rates and low unemployment are treated as political targets, and are used to bolster the careers of provincial officials, these problems will remain. One phrase that is commonly heard among Chinese economists is that 'data make officials, and officials make up the data' (shuju chengjiu guanyuan, guanyuan chengjiu shuju). 2003)

Euphemisms abound in this sphere. Here are a few examples (see Kynge

- daiye, waiting for work;

- $f e n l i u$, attached to one unit but working for another;

- neitui, retired early but getting a stipend;

- tingxin liuzhi, keeping a job but without pay;

- liangbuzhao, similar but with more emphasis;

- fang changjia, on a long vacation;

- tiqian tuixiu, early retirement;

- fuyu renyuan, no work but a token wage.

Indeed caution has to be paid to differences in definitions. China defines the jobless in a highly distinctive way. According to the State Statistical Bureau, unemployment refers to the urban registered unemployed who (a) possess nonagricultural residence; (b) are within a certain age range (16 to 50 for males and 16 to 45 for females); (c) are able and willing to work; and (d) have registered with the local labour bureau for employment (State Statistical Bureau, 2002: 588). Only the openly unemployed are eligible for what are known in the PRC officially as 'unemployment benefits'. In fact, another form of joblessness is perhaps more pervasive - 'hidden' unemployment' - referring to workers, often 
in the state sector, who have been laid off (xiagang). The State Statistical Bureau defines 'laid off' workers to be 'workers who have left their posts and are not engaged in other types of work in the same unit, but still maintain a relationship with the unit that they have worked in' (State Statistical Bureau 2002: 588). Workers who have been laid off are only given very basic living subsidies (shenghuofei) at subsistence levels, instead of unemployment benefits, and are not included in the registered unemployment rate. This convention has led to confusion by overseas observers, and accounts for the allegedly low rate of joblessness in China.

A White Paper on Employment and Social Welfare issued by the State Council stated that from 1998 to 2001, more than 25.5 million people were laid off from state-owned enterprises, of which 16.8 million managed to rearrange employment (as cited in O'Neill 2002: A01). These figures would suggest that 8.7 million are still laid off. Wang Dongjin, Vice-Minister of Labour and Social Security, pointed out that many of the jobless and those laid off from stateowned enterprises were low-skilled and middle-aged workers who had had a poor education and had been employed in traditional sectors such as coal, textiles and machinery (as cited in O'Neill 2002: A01). Wang's observation is supported by Maurer-Fazio's (2002) empirical analysis that demonstrates that education has become a key determinant of labour market outcomes in China's rapidly changing work environment. Educational attainment is now an important factor in the 'layoff decision': the more education a worker has, the better his/her protection from layoff. Similarly, the more education a worker has, the better his/her chances of finding new employment.

Wang openly acknowledged that China was facing a severe employment situation, and the numbers that had newly joined the labour force were at an unprecedented peak. In the coming few years, 12 to 13 million will enter the labour market every year. Even if China retains its current 7 per cent economic growth per year, only 8 million jobs will be created. This means the annual newly added unemployed will be 4 to 5 million. By the end of 2005, a new unemployed force of 20 million is expected to appear. While the precise total aggregates may be in doubt, this description seems plausible. Unemployment, intertwined with poverty, now poses a huge threat to both social stability and the rule of the Chinese Communist Party (CCP), and this demands an urgent policy response. Labour market programmes have emerged as an important employment policy tool in the reform era. The following section examines the institutional changes in the Chinese labour market in the pre- and post-reform era.

\subsection{Institutional changes in the Chinese labour market}

In their theoretical analysis of the recent economic reform process, Hussain, Stern and Stiglitz (2000: 4) argued most persuasively that the more successful aspects of China's transformation have been based on 'a process of institutional change that preserved and built on its basic codes and practices of behaviour'. 
Table 8.1 Institutional changes in the Chinese labour market

\begin{tabular}{ll}
\hline Pre-reform era & Post-reform era \\
\hline Role of the state & \\
Socialist ideology & Market principles \\
Direct allocation of jobs & Facilitating job search \\
Provisions from 'cradle to grave' & Individual self-reliant \\
State-owned enterprises & \\
Centralization & Decentralization \\
Life-long employment & Contract terms \\
Tool for full employment & Layoffs for efficiency \\
Workers as 'masters' & Workers as 'proletarians' \\
\hline
\end{tabular}

Table 8.1 shows a comparison of the institutional changes in the pre- and postreform era.

China's pre-reform labour system was the antithesis of the free market. The state claimed ownership of labour services and bureaucratically assigned workers to enterprises for life (tongyi fenpei). Workers' preferences concerning occupation or location mattered little. On the enterprise side, managers for the most part had to accept any and all workers allocated to them. Job mobility was minimal and would occur mostly as the result of workers' reassignments or transfers to satisfy the need of state-run organizations (Walder 1986: 8). Under these circumstances, where individuals are discouraged from searching for jobs, information about jobs is unimportant and meaningless.

Around 1992-1993, the policy of state job assignment was largely abolished. By the mid-1990s, the tongyi fenpei system remained only residually in large cities such as Shanghai (Davis 1999: 22-43). School graduates still have access to state-sponsored channels for employment, but they now have the option of using market channels such as advertisements, job fairs and employment agencies. The number of private enterprises, foreign-funded firms and other nonstate controlled businesses has significantly increased. Seen positively, the operation of labour markets made it legitimate for individuals to use all kinds of channels to search for jobs. Bian's (2002) study of job mobility in five Chinese cities indicated that from the pre-reform period to the 1980-92 and the post1992 period, job mobility through hierarchical channels ${ }^{2}$ declined sharply from 76 per cent to 52 per cent to 10 per cent respectively. Meanwhile, job mobility through market channels increased from 15 per cent to 32 per cent to 60 per cent respectively. These changes point to the decline of job assignments and the growth of labour markets in Chinese cities from 1980 to 1999 (Bian 2002: 4-7).

On the other hand, the abolition of the state allocation system also means that concerns about state-sector inefficiency began to override concerns about dismissals and layoffs. Enterprise reforms replaced the 'iron rice-bowl' with performance-based hiring, firing, and compensation. State-owned enterprises 
have begun to use labour contracts, adopt wage reform, and decentralize labour management. The policy of laying off workers (making them xiagang) was first experimented with and then applied nationwide in 1997. The effects were profound. The security once enjoyed by urban workers rapidly eroded. Chinese urban workers are no longer shielded from market forces. They bear the brunt of the adjustment costs as enterprises shed redundant workers in their attempts to become more efficient and profitable. Laid-off workers experience substantial periods of unemployment with minimal stipends. To address this issue, various localities have devised their own 're-employment projects' (zaijiuye gongcheng). Shanghai was chosen for our study because it was the pioneer in establishing the Re-employment Service Centre. Combining welfare provision, employment services and retraining programmes, the Shanghai Re-employment Service Centre was recognized by the central government as a 'learning model' for other local governments. These changes exemplify the notion that state institutions constantly readjust and revise themselves in response to new demands and circumstances, an important feature of the transitional economy (Solinger 1999 cited in Fan 2002: 107). We now briefly sketch out the research approach we used in the case study.

\subsection{Research methodology}

The main research methods we used in the citywide case study presented here draw on evidence gleaned mainly from both primary and secondary documents, media reports and official statistics. These we consistently approached with caution to build up an analysis and evaluation of the Shanghai re-employment model. Empirical field research in Shanghai in the form of over fifty openended, qualitative interviews with policymakers, managers, trade union representatives, workers and unemployed persons in the late 1990s and, with recent further contacts, up to the end of the year 2001, also provided supplementary valuable data. Visits were made to government departments such as the Labour and Social Security Bureau in Shanghai, as well as the Reemployment Service Centres. The operation of the placement service, retraining services and social security insurance was observed at first hand. ${ }^{3}$ The evidence we present below, we believe, has therefore robust empirical underpinnings.

\subsection{The Shanghai labour market model}

Figure 8.1 depicts a labour market model that summarizes the operation of the system in Shanghai. Over the past 40 years, 'active' labour market programmes have emerged as an important employment-policy tool, particularly in developed countries. This policy envelope includes a wide range of activities intended to increase the quality of labour supply (for example retraining), to increase labour demand (for example direct job creation), or to improve the matching of workers and jobs (for example job-search assistance). The objective of these measures is primarily economic: to increase the probability that the unemployed will find jobs or that the underemployed will increase their productivity and earnings. 
Input

- Registered unemployed

- Laid-off workers

- Frictionally unemployed

- New entrants to the labour market

Process

Active Labour Market Programmes

- Training / Retraining

- Job creation

- Wage subsidy

- Public employment service

- Counselling

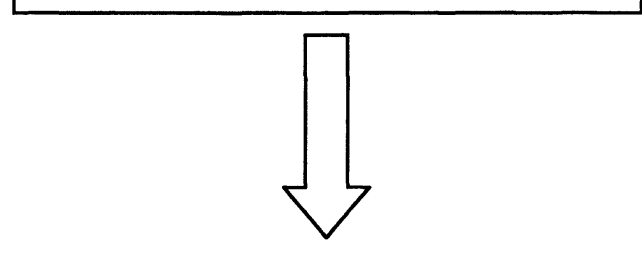

Output

- Employed

- Self-employed

- Remain unemployed

$\rightarrow$ rely on passive labour market programmes

- Unemployment insurance

- Minimum living subsidy

Figure 8.1 Chinese labour market model

However, more recently the case for active labour market policies has also emphasized the potential social benefits in the form of the inclusion and 
participation that comes from productive employment (Betcherman et al 2000: 1). Labour supply (school leavers, job changers and laid-off workers) is the primary input to the systems model. This supply of labour, it is hoped, will be transformed by the active labour market programmes of the government, leading to positive output of employment. Shanghai has also established a 'passive' labour market policy of unemployment insurance.

\subsubsection{Retraining}

Public support can come in the form of direct provision of training (for example through public training institutes), financial support for trainees (for example by funding training costs and/or subsidizing trainees) or providing 'infrastructure' services (such as labour market information, licensing, monitoring and credential services). State and city governments have a range of potential roles: direct provision, regulation, providing information and standards, and financing. Many governments are moving away from the role of direct provider and focusing more on addressing market failures in information and financing, while leaving more of the delivery to private providers (Betcherman et al 2000: 5), but the role of the state is prominent in Shanghai. The training programmes are designed, financed and delivered by the government. The training centres are attached to the placement centres, widely known in Shanghai by the description qiandian hou gongchang (employment-service provided in the shop, training in the backyard). Each class will have about 40 trainees. The length of training differs from job to job: domestic helpers will be trained for three weeks, six hours a day; cooks and technicians will receive training for half a year, but only three days a week. According to the head of the training centre visited, the success rate in job placement is often boosted from the normal rate of below 30 per cent to as high as 70 per cent for domestic helpers (field interviews, June 1999). In Shanghai, retraining is free of charge for jobseekers certified to be xiagang workers and unemployed. Some laid-off workers do benefit from various training programmes, ranging from cooking and hairdressing to public relations, law and marketing (China Daily, 30 January 2001). If training is for self-development purposes, however, each trainee will have to pay $300 \mathrm{RMB}$ to take part in the course.

\subsubsection{Creation of employment}

In general, job creation programmes across the world are designed to support the creation of new jobs or the maintenance of existing ones. Three broad types of programmes fall under this category. First, there are subsidies to encourage employers to hire new workers or to keep employees who might otherwise have been laid off for business reasons. These can take the form of direct wage subsidies (for either the employer or worker) or social security payment offsets. These types of subsidies are always targeted to a particular category of worker or employer. The second category involves direct job creation in the public or non-profit sector through public works or related programmes. Typically, 


\section{Grace O. M. Lee and Malcolm Warner}

government funds used for these programmes cover compensation costs to hire previously unemployed workers, usually on a temporary basis. Third, support is sometimes offered to unemployed workers to start their own enterprises (Betcherman et al 2000: 6).

Direct public employment creation policies are set up to lessen unemployment by creating jobs and hiring the unemployed directly. Such policies target the displaced and the long-term unemployed, with a view to help them regain contact with the labour market, thereby minimizing the likelihood of stigmatization, skills obsolescence and marginalization. In devising solutions to the employment problem, the Shanghai government has created more employment opportunities by any reckoning. The Shanghai Labour Bureau has, for instance, invested in minor improvement programmes at the district level, and has allegedly created over 20,000 vacancies. These vacancies concentrate on public hygiene (baojian), public security (bao'an), environmental protection (baolu), and the maintenance of public facilities (baoyang). ${ }^{4}$ Street committees also help in providing employment programmes. These committees retrain laidoff workers to do work such as the maintenance of buildings and 'green' areas, sanitation, domestic services and security. Funding for some of these programmes comes from individual households, with each paying about 36 cents (in Chinese currency denomination) per month for committee services including window-cleaning, garbage-disposal, maintaining recreational facilities and activities, maid-services and even providing haircuts (Erickson and Hsieh 1998: 52). These services have clearly become 'affordable' as urban dwellers in China become wealthier. ${ }^{5}$

Another type of job creation that is important to cite is the Self-Employment Creation Measure or Micro-Enterprise Development Assistance. Technical assistance, credit and other support can contribute to the creation and promotion of small-scale new businesses and self-employment. China has taken some novel initiatives which we can mention here. In Shanghai, the Baibang Community Service Company and the Baibang Industrial Centre are examples of selfemployment creation (field interviews, June 1999). The former takes care of the aged and the less-educated redundant workers, while the latter caters for the needs of semi-skilled workers. The Baibang Community Service Company was set up in 1994 to match the employment needs of laid-off workers with the need for family services in the community. Officials who run the company are seconded from the Ministry of Social Welfare. They rely on the District Committees to identify xiagang workers and their appropriate skills. Government training institutes provide free training and accreditation of the worker's skills. Promotion of the service is through street posters, free local media such as newspapers, television and radio-broadcasts, and word-of-mouth. Services are developed according to the needs of the neighbourhood, such as childcare, elderly care, cleaning and preparation of meals. The company charges a commission ranging from 20 to $50 \mathrm{RMB}$ from the workers, and 10 per cent or 50 RMB per job from the family-service recipient. As of June 1999, the company claimed it had been successful in finding jobs for over 200,000 workers (field interviews, June 1999). 
Private banks are often unable to conduct the comprehensive risk assessments required for offering credit to unemployed workers who want to create their own businesses. Public programmes to support small business loans can contribute to the removal of this distortion arising from credit rationing. An example of a selfemployment creation agency found in Shanghai is the Baibang Industrial Centre, established in May 1998 (field interviews, June 1999). A bankrupt state-owned coal-products factory was restructured into 18 units leased to redundant workerentrepreneurs. The government provides start-off loans each ranging from 50,000 to 150,000 RMB. Employees working in the industrial centre should be workers who are either laid off or retired from state enterprises (the ratio is about 70 to 30 ).

\subsubsection{Job referral and counselling}

Market economies are imperfect because of, among other factors, information asymmetry. For example, jobseekers have insufficient information about the distribution and specification of job openings, and employers have insufficient and inaccurate information about the distribution of qualified job candidates (Devine and Kiefer 1991 cited in Bian 2002: 3). Employment services fulfil such brokerage functions as matching jobs with jobseekers.

China too has taken up new ways of finding work for the unemployed. In Shanghai, however, private agencies are restricted and the public employment service operates under near-monopoly conditions. There have been 452 registered employment agencies in all to provide employment services in Shanghai. Of these, 338 were established under the Labour Administration Division and 110 are operated by industries and social organizations such as the All-China Federation of Trade Unions (ACFTU), the Association for the Handicapped and the All-China Women's Federation (ACWF). Enterprises register their vacancies with the placement centres and then select workers through open recruitment. Vacancies reported by employers are advertised online (since 1 July 1997, state-operated employment agencies in Shanghai have been inter-connected electronically to provide 'real-time' information on the job market to jobseekers; all the state-established agencies are linked vertically and horizontally, as well as with nine employment agencies set up by the industries).

As well as displaying job vacancies, information on retraining is also available on the Internet, though this is not necessarily of much use to the poor, except at official agency centres. Retraining courses are designed, financed and delivered by the government. According to the Deputy Head of the Shanghai Re-employment Service Centre, the content of these training programmes is intended to link to the needs of the market. Out of the ten positions advertised every week in the local newspapers which are in greatest demand, training programmes will be offered for the first four. Examples of such vacancies include positions as cashiers, computer technicians, cooks, domestic helpers and electrical technicians. The training centres are attached to the placement centres. Upon completion of training, the trainees will be referred to jobs. 
Many new types of active labour market measures are now in place. Placement officers, for example, provide counselling to jobseekers on labour market information, and re-educate those who possess the 'iron rice-bowl' mentality to change. To establish rapport between the counsellor and his or her client, individual counsellors will follow through cases. All counsellors are trained and are required to pass a professional examination annually. Overseas training in Germany has been arranged for outstanding counsellors. The state closely monitors the situation of workers who have been 'disassociated' from state enterprises. Hardship cases are entitled to a subsistence allowance (zuidi shenghuo butie) of 297 RMB per month when repeated referrals, counselling, and retraining do not work. Unlike the European model (which provides generous unemployment support that is intended as adequate income maintenance), the Chinese government is extremely careful to seek a balance between stringent procedures and social stability. In any case, this subsistence allowance is only payable for two years, after which the unemployed person will only be entitled to a maximum unemployment insurance of $432 \mathrm{RMB}$ per month depending on various factors like age and years of contribution to unemployment insurance (see Table 8.2)

Table 8.2 Monthly rate of unemployment insurance in Shanghai 2003

\begin{tabular}{|c|c|c|c|}
\hline $\begin{array}{l}\text { Cumulative } \\
\text { contribution in years }\end{array}$ & $\begin{array}{l}\text { Age of the } \\
\text { unemployed }\end{array}$ & $\begin{array}{l}\text { Monthly payment for first } \\
12 \text { months }(R M B)\end{array}$ & $\begin{array}{l}\text { Monthly payment for } \\
\text { next } 12 \text { months }(R M B)\end{array}$ \\
\hline \multirow[t]{2}{*}{1 to less than 10} & Less than 35 & 297 & 280 \\
\hline & 35 and above & & \\
\hline \multirow[t]{2}{*}{10 to less than 15} & Less than 35 & 324 & 280 \\
\hline & 35 and above & & \\
\hline \multirow[t]{2}{*}{15 to less than 20} & Less than 40 & 351 & 281 \\
\hline & 40 and above & & \\
\hline \multirow[t]{2}{*}{20 to less than 25} & Less than 45 & 378 & 303 \\
\hline & 45 and above & & \\
\hline \multirow[t]{2}{*}{25 to less than 30} & Less than 50 & 405 & 324 \\
\hline & 50 and above & & \\
\hline 30 and above & All & 432 & 346 \\
\hline
\end{tabular}

Source: Shanghai Laodong Baozhang Fuwu Wang (Shanghai Labour Protection Services Net) http://www.sh.lss.gov.cn/zcwd/detail.jsp?mes_oid=129276 


\subsection{Discussion and evaluation}

As a 'transitional' mechanism for managing unemployment in industrial China, particularly as it is manifested in the phenomenon of laid-off workers, the Reemployment Service Centre may be seen as a possibly viable institutional bridge between work-unit and society relating to the wider societal management of human resources, in both theoretical and empirical terms. It is clearly, in our view, a compromise between the protection of the work-unit (danwei) system and the harsh course of simply pushing the responsibility for the unemployed onto the wider society. This mechanism is different from both the past practice of the Communist planned economy (where surplus workers were resettled by the enterprises) on the one hand and the American liberal, market-driven labour market management system practice of just 'dumping' such workers onto society, on the other.

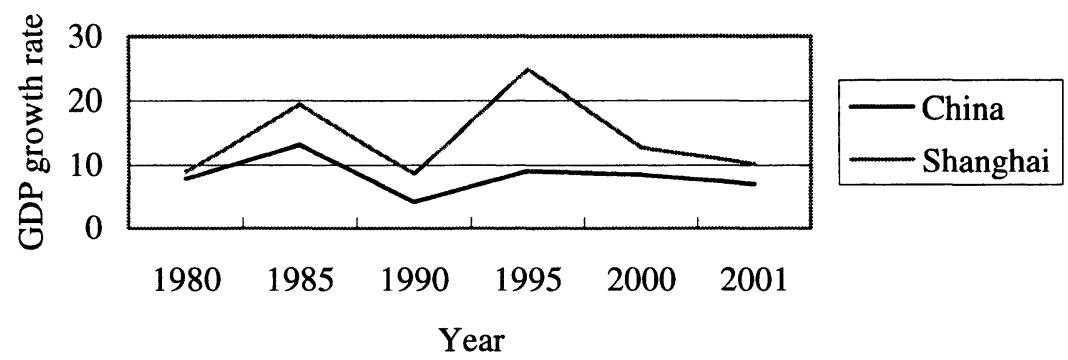

Figure 8.2 GDP growth of China and Shanghai, 1980-2001

Sources: State Statistical Bureau (2002), Shanghai Statistical Bureau (2002).

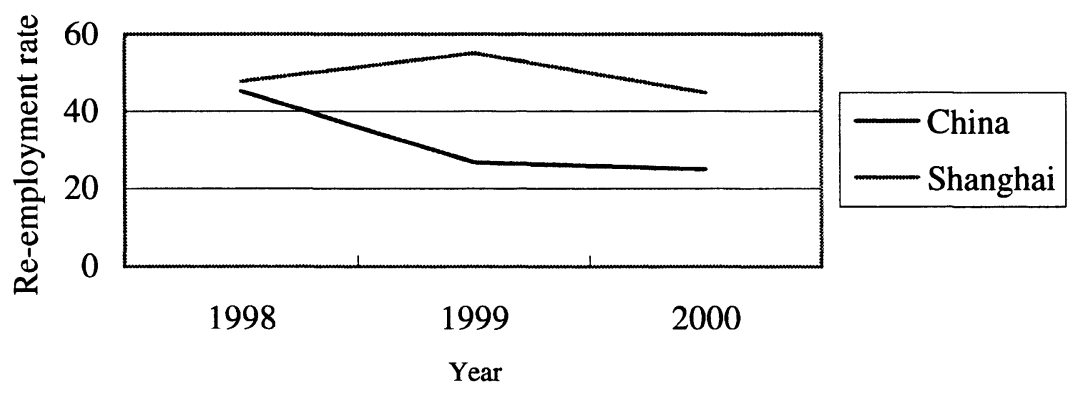

Figure 8.3 Re-employment of laid-off workers in China and Shanghai, 1998-2000

Sources: State Statistical Bureau (various). 


\section{Grace O. M. Lee and Malcolm Warner}

However, the relative success of this programme in Shanghai does not necessarily mean that it would also succeed if implemented nationwide. It has succeeded because the rapid growth of the Shanghai economy has helped to create jobs and ease pressure on employment. ${ }^{6}$ Indeed, Shanghai has been one of the fastest growing areas in China, its economy consistently growing faster than the national average in the last decade or so (see Figure 8.2).

Provided that the pace of economic development is different among various regions, it is not surprising that the establishment of Re-employment Service Centres in some cities does not have the same achievements as that of Shanghai or other affluent coastal cities. One indication is that the re-employment rate of Shanghai is much higher than that of the whole country (see Figure 8.3).

A recent survey by the All-China Women's Federation (ACWF) indicates that over one-fourth of laid-off women who have landed jobs again are working in the service sector of their communities, or are privately hired or self-

employed. ${ }^{7}$ This can only happen in prosperous economies. In the first half of 2002 , a record high of 30,000 private enterprises were registered in Shanghai, ${ }^{8}$ which is deemed China's economic 'powerhouse'. The city now has nearly 210,000 private enterprises, employing 2.3 million people, or one in every three Shanghai workers. Local analysts attribute the fast growth to the policy adopted by local authorities at the end of 2002 to open more sectors to private investors. ${ }^{9}$

There have been many instances of self-employment or starting of small enterprises with training of skills and funding in terms of loans from government. ${ }^{10}$ To give some examples, a xiagang textile worker started a fourperson sweater-knitting workshop with a loan of 4,000 RMB from her local women's federation; another worker studied massage and opened a small massage clinic in a residential square with two classmates.

To facilitate entrepreneurship, the Shanghai Re-employment Centres successfully recruited around 500 professionals to volunteer in giving advice on starting businesses (People's Daily, 26 September 2002). These professionals were reported to include university professors, engineers, industrialists, and heads of social and public organizations. Consultation sessions were held on Saturdays on an appointment basis. It was reported that 15,500 consultation sessions were offered in 2002-003; around 2,000 entrepreneurs started their own businesses and created thousands of job opportunities; and around 380 entrepreneurs successfully applied for loans up to 40 million RMB. Another new employment scheme set up by the Shanghai government, the 40-50 Project, has a different approach to the problem: the government provides tax breaks, financial rewards and loan guarantees to new, labour-intensive private businesses as long as they hire laid-off workers (BBC News, 19 March 2002).

\subsection{Concluding remarks}

In relatively well-off Shanghai, re-employment centres do provide a 'safety net' for xiagang workers as the minimum living protection for laid-off workers provided by the Re-employment Service Centres has been gradually merged with the unemployment insurance system. However, the types and quality of 
services provided by the centres in different localities do vary considerably. In some areas there are also cases where the centres fail to provide any assistance. For instance, some centres in Wuhan merely provide a form for the jobseekers to fill out but have virtually nothing more to offer. It was reported that a desperate worker received no money, no training and no placement, and heard nothing from his centre for 18 months after he had signed a contract with them (Solinger 2001: 683). Such problems often provoke protests and demonstrations: for example, 30,000 workers from 20 bankrupt factories marched in the streets of Liaoyang in the northeastern 'rust-belt' in March 2002 (see Becker 2003). The regime gravely fears a cloning of the Polish-style 'Solidarity' movement - a reason why Deng Xiaoping earlier tried to increase worker involvement in enterprise decision-making at the beginning of the reform process in the early 1980s.

Moreover, officials from the Ministry of Labour and Social Security warn that the chances for xiagang workers to obtain re-employment might deteriorate in the years to come. Statistics from the Ministry indicate that about 23 million labourers will be seeking jobs in urban areas in the next three to four years from 2002 , but there are only expected to be about 8 million job opportunities available (China Daily, 24 September 2002). In the first half of 2001, among those 7.69 million xiagang state workers, the official statistics concede that only 11.1 per cent of the total had succeeded in finding new jobs. This proportion was 4.9 percentage points lower than that for the same period in the previous year (China Daily, 28 July 2001; People's Daily, 30 July 2001). This record is not very encouraging in the face of the mass redundancy China faces as a result of further 'deepening' of the reforms and the consequences of now ongoing trade liberalization.

China's entry to the World Trade Organisation (WTO) in late 2001 and the speeding up of the structural readjustment of industries will put an even more serious strain on the management of human resources broadly envisaged and will increase employment pressures in the coming years as globalization advances (see Warner 2002). The Green Paper Report on 'China's Population and Labour Problems' published by the Chinese Academy of Social Sciences pointed out the impact of China's accession to the WTO on China's employment situation: in the short term, urban unemployment is likely to increase by 3 to 4 million, and the unemployment rate to rise by 2 per cent. The impact on agriculture may be most severe, and it is estimated that agricultural employment could decrease by 10 million. The impact of the WTO on agriculture has important implications for workers laid off from state-owned enterprises. Increased rural-urban migration may not only raise urban unemployment but also place downward pressure on wages, especially in labour-intensive industries. Even though China aims to contain the 'official' unemployment rate within 5 per cent during the tenth Five-year Plan (2001-2005) (China Daily, 7 August 2001), it is clear that the problem of unemployment will still be vexing the Chinese government in the foreseeable future (see Becker 2003) and may likely still constitute a potential threat to social stability.

The system can probably only maintain its status quo if there are more 'winners' than 'losers' (see Warner 2003a). The rate of economic growth must 


\section{Grace O. M. Lee and Malcolm Warner}

keep increasing at above 8 per cent per annum just to absorb the redundant old and job-seeking youth. If China can continue its almost unprecedented rapid economic expansion, it might just keep matters under control. Otherwise the system will prove to be unstable and the future unpredictable.

Notes

* The authors would like to acknowledge the City University of Hong Kong for financing the field research of one of the authors in Shanghai. Funding granted to the research project A Tale of Two Cities: The Social Policy Challenge in Hong Kong and Shanghai was co-ordinated by Linda Wong and Gui Shi-xun.

1 The report was published in Zhongguo Jingji Kuaixun [China Economic News Bulletin], 5 April 2002.

2 Bian merged job change into different channels: 'Hierarchy' refers to various methods of job assignments, including replacement of parents or relatives (dingti), internal hiring of employees' spouses or children (neizhao), assignments by the state at job entry (guojia fenpei), and reallocation and transfer by the organization where one works (zuzhi diaodong); and 'market' refers to various methods of open application and hiring processes in which no assignment by either state or any organization is involved. This includes self-employment, direct application, use of employment services, and use of any ads and media methods.

3 Our earlier research in this area has appeared as Lee and Warner (2001 a, 2001b and 2002).

4 Interview, CEO, Shanghai Baibang Services Limited, Shanghai, May 1999.

5 China's first survey of assets of urban families revealed that urban dwellers are becoming wealthier, with an average of 228,300 RMB (US\$27,600) in total assets for every family. See China Daily, 28 September 2002.

6 Interview, Economist and Vice Director, Shanghai Changning District Labour Bureau, Shanghai, June 1999.

7 China Daily, 25 September 2002. In the survey conducted by the All-China Women's Federation covering 3,633 women from across the country, working for private enterprises providing community services and self-employment follow working for state-owned enterprises on the list of 'most favoured places to look for work'.

8 China Daily, 8 October 2002. In the first half of 2003, the output of private industrial enterprises and the business turnover of private retail enterprises totalled 157 billion RMB (US\$18.92 billion), with 7.3 billion RMB (US $\$ 880$ million) in taxes paid. In the domain of foreign trade, more than 140 private enterprises were granted foreign trade rights and exported commodities worth US $\$ 54$ million in the first half of 2003, a significant year-on-year increase of 200 per cent. At the time of writing, the registered capital of private enterprises in Shanghai had reached 210 billion RMB (US $\$ 25.3$ billion), with 121 corporations contributing more than 100 million RMB (US\$12 million) each in registered capital.

9 Urban construction, education and hospital operations, once 'forbidden areas' for private investment, have now been opened to private entrepreneurs. To assist private companies, mainly small and medium-sized enterprises, to find sources of funding, Shanghai has set up a credit guarantee system and has allocated special loans for private enterprises. According to a Xinhua news report, local banks provided 5.2 billion RMB (US $\$ 627$ million) in loans for 3,177 projects from 1995 to 2001, taking the leading position in China in this area.

10 Interview, Vice Director, Nanshi Baibang Zhengshi Gongye Zhongxin, Shanghai, September 2001. 


\section{SECTION THREE}





\title{
9 Employee perceptions of social protection reform in Shanghai: diversity across ownership forms and occupations
}

\author{
Cherrie Jiuhua Zhu, Chris Nyland and \\ Brian Cooper
}

\subsection{Introduction}

As China has expanded the scope and role of the market within its economy and society, the job security of its citizens and workers has been undermined by the associated dismantling of the old system of social insurance (the 'iron ricebowl') that prevailed through the period of command socialism. Consequently the government has begun the construction of a social protection regime that is suited to a market economy. This is a process which the state recognizes needs to be managed with care and sophistication if social stability and a high growth rate are to be sustained. It is also recognized by the government that it is important to have a clear understanding of how the reforms are perceived by the population. Recognition of this need and a genuine concern for the plight of the dispossessed has induced both Chinese and international scholars to monitor closely how the broad population and strategic elements within the community are perceiving the reforms. Underpinning this sensitivity is also an awareness that perceptions affect how individuals and groups cope when confronted with fundamental changes to practices and institutions central to their needs. Shanghai has been an important focus for those undertaking research related to perceptions because the city's administrators have played a pioneering role in the development of the emergent social protection regime.

In this chapter, we extend the perception research by detailing the diversity of employee views on social protection reform that prevail across firms with differing ownership forms and occupations. The research on perception has so far tended to concentrate on state-owned enterprises (SOEs) at a time when China's government is committed to policies that are bound to further decrease the number and relative significance of state enterprises. The chapter has five sections. First, we highlight changes in the ownership structures of enterprises and the social protection system. Second, we review the results of previous studies that have sought to determine how the reform of the social protection regime is perceived in China. We then explain the research method employed including the background of the survey that was conducted in 2002 to determine whether and how employees' views of social protection reform vary across ownership types and occupations, and detail the measures used in the survey questionnaire. In part four, we proceed to recount the results of the survey. 


\section{Cherrie Jiuhua Zhu, Chris Nyland and Brian Cooper}

Based on a sample of 299 employees, variations in attitudes towards social protection reform across several dimensions are reported. These include the changing business environment, enterprise competitiveness, personal risk management, labour mobility between public and non-public sectors, motivation due to the sense of security provided by the new protection system, and labour relations. We then apply multivariate analysis to the survey data to examine determinants of employee satisfaction with social protection policies. We conclude by discussing the survey results and their implications for employees, managers and policymakers.

\subsection{Changes in the ownership structure and social protection system}

Among the firms surveyed in this study, there were four major ownership forms: state-owned enterprises (SOEs), privately owned enterprises (POEs), foreigninvested enterprises (FIEs) and shareholding enterprises (SHEs). These organizations were generally classified as state (SOEs) and non-state (POEs, FIEs and SHEs) sectors. While POEs and FIEs started their development in the early 1980s, shareholding or joint-stock structure has been used widely to reform and restructure the massive state-owned sector only since the mid 1990s. For example, the number of SHEs increased from 72,000 in 1997 to over 300,000 in 2001 (an increase of 320 per cent), and the number of people employed also increased more than threefold from 6.44 million to 27.47 million (Census Centre of the China Statistical Bureau 2003). According to the second nationwide organization census in 2002 , the shareholding structure has become a major ownership form for companies and enterprises in China. It usually has mixed ownership because the majority of SHEs are not publicly listed companies and have mixed investors from both public (for example state and collectively owned organizations) and private sectors (for example POEs, FIEs or individuals) (Census Centre of the China Statistical Bureau 2003). In the Third Plenary Session of the $16^{\text {th }}$ Communist Party Congress held in October 2003, the CCP leaders outlined the need for more diversified forms of public ownership and stated that the ideal approach was a 'shareholding system that absorbs investment from various channels' (AFR 16 October 2003: 10).

In the last 25 years, China has witnessed a rapid growth in the number of nonstate enterprises as a result of economic transition and reform in the public sector. For example, the percentage of the total number of POEs, FIEs and SHEs in relation to the total number of enterprises in China increased from 29.1 per cent in 1996 to 58.2 per cent in 2001 (Zhao 2003). Furthermore, in 2001 the total industrial output from POEs increased by 69.2 per cent compared with 2000 , and FIEs produced an increase of 30.7 per cent in contrast to a 14.9 per cent decrease in output from SOEs (Wang 2003). In 2002 Shanghai had 210,000 private enterprises employing 2.3 million people, or one in every three Shanghai workers (China Daily October 8 2002). In the planning communiqué issued by the 2003 Communist Party Congress, the Party identified 'the need for greater promotion of the economy's private sector' and proposed that 'private firms be 
given equal rights in investment, lending, tax, land use and foreign trade' ( $A F R$ 16 October 2003: 10).

While the transition has increased diversity in the workforce in China in terms of different types of enterprises and a diverse range of employees, it has challenged the traditional 'iron rice-bowl' form of social protection that had previously characterized China's work units or organizations (danwei) in the public sector. Before the social protection reforms started in the 1990s, the Chinese social insurance system had two major features: the separation of urban and rural areas and segmentation of urban enterprises based on their ownership status (Hussain 2000). Private industry was negligible during Mao's regime and no social protection programs existed in that sector (Chen 1990; Lee 1993; World Bank 1990). In the public sector, social protection was tied to the 'work unit', not to society, and work units generally provided urban workers with permanent employment and a range of social insurance benefits that were noncontributory and included food and housing subsidies, pensions, health services, maternity assistance, and insurance against injury, disability, and death (Li 2000; Guan 2000; Wang 2001). The highly decentralized administration lacked an established mechanism for portability of eligibility and benefits, which discouraged employees from moving across organizations, industries or sectors (Dai 1999; Song and Chu 1997); consequently, employees in China were called 'unit people' (danwei ren) rather than 'social people' (shehui ren). Urban employees in the state sector enjoyed cradle-to-grave benefits, and work units were responsible for their welfare even after retirement (Whiteley et al 2000). By the end of 1994, about 90 per cent of workers in SOEs and about 70 per cent in collectively owned enterprises were covered by the social protection system (Ge 1996).

By contrast, the new regime currently being developed links job security to the market, provides a less encompassing range of benefits, and greatly increases the share of the cost borne by individuals. Guan (2000) has accurately described the emerging regime as 'societalization' (shehuihua): that is, a society wide system in which everyone receives the same level of social protection irrespective of where they are employed. Shanghai, for example, has introduced a three-tiered pension and medical insurance system to every type of enterprise from the late 1990s, and the traditional 'direct-planned welfare provision' has been replaced by a 'redistributive process' in welfare provision (Guan 2000: 119). As a result, employees in different sectors are theoretically treated equally in terms of their social protection.

While many researchers have focused on the decreased social security accorded to employees in SOEs through the breaking of the iron rice-bowl (see for example Warner 2000), little attention had been paid to the fact that the establishment of a comprehensive national social security system would in fact heighten the security enjoyed by the majority of city workers. This is because an increasing number of people are employed outside the state owned sector, and these people (especially employees working in the private sector) would not enjoy any substantial protection from the vagaries of the market but for the reforms. The new social security system is expected to assist employees from either state or non-state enterprises to handle risks including those induced by 


\section{Cherrie Jiuhua Zhu, Chris Nyland and Brian Cooper}

the new market economy (such as retrenchment or unemployment). Furthermore, as the new social security system maintains employees' coverage from job to job, it will facilitate labour mobility across enterprises with different ownership structures. As a consequence, under the new system, it is more likely employees will select their jobs based on their skill rather than the ownership type of the enterprise. Precisely how employees respond to these changes, however, will be dependent to a significant degree on how they perceive the changes to the regime. It is to this issue that we now turn.

\subsection{Monitioring perceptions and coping strategies}

Researchers who have examined the marketization of China's social protection regime have concentrated on analysing the way the reforms are financed and governed (Chen 2001; He 2003; Meng 2003; Tian 2003; Yin et al 2000), the social and political implications of associated regulations and programs (Guan 2000, 2001b; Leckie 2003; Saunders and Shang, 2001; Wang 2001; Whiteford 2003), and the costs to employees induced by breaking the iron rice bowl (Cook 2002; Mok et al. 2002; Price and Fang 2002; Smyth 1999; Zhu et al 2004). This research is of great value but does not necessarily clarify how the populace views the market-oriented universal social protection regime that is being introduced across China. Understanding how workers perceive the reform of social protection is important because there is a spectre haunting China, the spectre of organized resistance on the part of those whom the market has dispossessed. To contain this danger, governments and others with a stake in policy management need to be aware of how the reforms are being perceived by the populace. A clear understanding of these perceptions can also assist the attainment of a number of more limited goals. For example, such knowledge can play an important part in the development and maintenance of active labour market policies and human resource management strategies.

That there is a need to incorporate the social security dimension into the analysis of labour market and industrial reform often goes unappreciated. Price and Fang (2002), for example, surveyed unemployed workers across seven cities to assess their coping strategies, but failed to include access to welfare provisions amongst the explanatory variables they considered. This was despite the fact that welfare provisions for the unemployed vary markedly across the cities of China. The need to include the social insurance variable in analyses of both the labour market and individuals' coping strategies is also evidenced by the fact that though marketization has made alternative forms of employment available, the non-state sector remains an unattractive employment locale for many workers. This is especially so for those retrenched and unable to gain jobs that provide adequate social insurance provisions (Maurer-Fazio 1995; Smyth 1999). As Gu has observed:

The majority of workers laid off from the state sector prefer to be reemployed by their original work units or by other work units in that sector (or the collective sector) rather than in the private sector. This is 
a rational preference because within the institutional configuration of the private sector, no systematic welfare provisions have been established. Workers are afraid that if they join the private sector and then lose their jobs, they will lose unemployment benefits, lay-off aid, medical care, and (most important) pensions. Even if they have job opportunities in the private sector, many decline them and maintain their status as laid-off workers unless new offers have some specific attractions (Gu 2001b: 106).

That there is a need to have a clear understanding of the way social protection reform is perceived by the population is appreciated by China's government. This is evidenced by the fact that social security was explored in a State Statistical Bureau survey of 40,000 urban families undertaken in 2000 in preparation for the White Paper on labour and social security that was issued in April 2002. In undertaking this survey the researchers took particular care to determine how interviewees perceived the increasing social inequality that has become a characteristic of China's marketization process, and discovered that this was an issue of deep concern to many (Lee et al 2002).

Determining the importance that individuals place on social protection and whether social protection reform is an area of concern has also become a tool and a product of private market researchers. These firms have explored this topic primarily in order to provide for the needs of the emerging private insurance industry. China Mainland Marketing Research Co. (CMMR), for example, conducted random sample questionnaire investigations in 31 cities across China in October and November 2002 to determine citizens' views on 'social life issues and household life status' (China Daily 27 December 2002). The researchers surveyed over 12,500 urban citizens aged between 18 and 69. It was found that a large majority of citizens believed their living standard had improved markedly over the previous five years and most interviewees were optimistic about the future. When asked to rank the social issues of most concern, employment and medical system reform rated highly as worries but social security 'topped the list' (see Table 9.1).

Not unexpectedly, views regarding social security and unemployment differed across the social spectrum (see Table 9.2). Table 9.2 indicates that while over half of the people ranked in the 'bottom stratum' (54.3 per cent) showed deep concern about the issue of 'social security', there was less concern amongst the more affluent. Nevertheless, over 40 per cent of people at all but the 'upper layer of the top stratum' shared the same concern. In summarizing their results, CMMR concluded that 'people in lower social strata care more about their daily life while people in higher strata care more about national affairs and tend to have more political orientation' (CMMR 2003, see Table 9.2). 
Table 9.1 The ranking of 'Hotspot' social topics among urban citizens (multiple choice)

\begin{tabular}{|c|c|c|c|c|c|}
\hline Type of social topics & Ranking & $\%$ & Type of social topics & Ranking & $\%$ \\
\hline Social security & 1 & 45.5 & Environmental control & 9 & 12.3 \\
\hline Unemployment and employment & 2 & 33.8 & Motherland unification & 10 & 7.4 \\
\hline Medical system reform & 3 & 31.3 & Western China Development & 11 & 7.2 \\
\hline Public order & 4 & 28.6 & Salary increase of civil servants & 12 & 6.2 \\
\hline Anti-corruption & 5 & 27.2 & $\begin{array}{l}\text { Increase of overall national } \\
\text { strength }\end{array}$ & 13 & 6.2 \\
\hline Education system reform & 6 & 17.5 & $\begin{array}{l}\text { Reform of state-owned } \\
\text { enterprises }\end{array}$ & 14 & 6.2 \\
\hline Impacts of WTO entry & 7 & 13.7 & Teenager education & 15 & 6.1 \\
\hline Medicine price & 8 & 14.3 & Others & 16 & 5.0 \\
\hline
\end{tabular}

Source: CMMR (2003)

Table 9.2 Hotspot social topics most concerned among different social strata in cities in 2002 $(\%$, multiple choice)

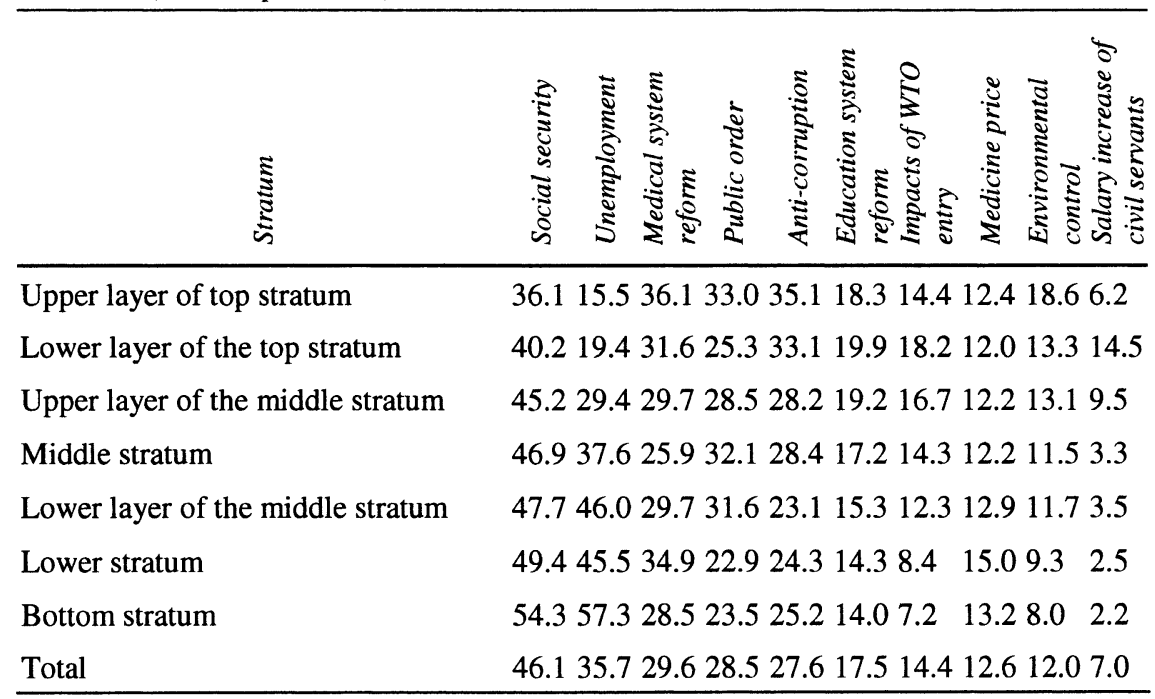

Source: CMMR (2003)

The social protection perception literature generated by state and market researchers has also been enriched by academics. Notable amongst the latter is a report by the Institute of Development Studies undertaken in collaboration with the China Women's College. Prepared by Cook and Jolly (2000), this study explored the perceptions of workers who had been made redundant by restructured SOEs. Interviews were undertaken with people laid off in three 
cities, with the explicit intention of informing policy interventions. It was found that not all laid off workers were poor but many suffered from a perceived loss of status, feelings of worthlessness and vulnerability to discrimination, exploitation or exclusion. Most believed unemployment and the inadequacy of social security benefits had compelled them to take up livelihoods formerly despised, restrict their diet, spend less on educating their children and elderly parents and curtail their social interactions. Cook and Jolly also report that male worker resentment is compounded by the fact that many unemployed men suffer guilt because without a job or adequate social security they are compelled to rely on their wives for support. Conversely, women tend to find it easier to accept new forms of work but they deeply resent losing the esteem they enjoyed when depicted as model socialist workers, and feel bitter about the loss of the social insurance benefits that were associated with this high-status position. Generational differences in perceptions were also apparent. Despair and resentment was especially acute amongst the young with individuals in their thirties perceiving themselves as old, unemployable and unable to compete for jobs.

Similar perception research has subsequently been reported by Mok et al. (2002). Again it was found that the vast majority of the retrenched had limited access to social security benefits, and few welfare entitlements with the exception of medical insurance. And again it was found that the combination of unemployment and the lack of adequate social insurance benefits has generated a 'strong sense of destitution and betrayal' amongst those who once were 'labour aristocrats'. The breadth and intensity of these perceptions, Mok et al. (2002) conclude, need to be appreciated by China's government which, they also insist, needs to do much more than is presently being done in the areas of unemployment, medical insurance and pensions.

While the researchers discussed above have focused on how citizens and workers perceive the current social protection situation, Wong et al (2000) have explored popular perceptions regarding responsibility for the provision of social protection. Focusing on Shanghai, because this is arguably the city in China most advanced on the path of marketization, they sought to determine where citizens tend to locate responsibility for social security and who they blame for the prevalence of insecurity and immiseration. Wong et al. (2000) collected their data by random sampling across 16 districts of Shanghai. They found that the overwhelming majority of respondents accepted that they had experienced substantial improvement in their lives and that there were many new opportunities available to further improve living standards. However, when the researchers turned their attention to individual life satisfaction, they found that barely half the respondents were satisfied with many practical areas of life and that it was widely believed inequality was unacceptably high. It was also found that most interviewees blamed poverty on institutionalized social injustice rather than on government policy failure, adhered to a clear and strong pro-welfarist orientation, and strongly believed that the state has the primary responsibility for providing for the social protection needs of the community. The respondents were overwhelmingly clear about the four traditionally welfarist functions of the state: nine-tenths were in favour of guaranteed jobs; nearly all favoured equal 


\section{Cherrie Jiuhua Zhu, Chris Nyland and Brian Cooper}

education for children; nearly seven-eighths endorsed the narrowing of the income gap; and nine-tenths endorsed a guaranteed basic income (Wong and Lee 2000: 113).

Similarly, Beijing Social Psychology Research Institute conducted surveys on the social protection provided to the people in Beijing in 2001 and 2002 among over 1000 residents living in the eight districts of the city (http://www.chinaminyi.org.cn). Three major findings of the research are related to the social protection enjoyed by people from different types of organization, the responsibility for individuals' future social protection, and the purchasing power of commercial insurance. It was found that compared with people working in other types of organization, those from POEs had the lowest coverage of social protection; 25 per cent of the respondents from POEs reported there was no social insurance paid for them, while another 14 per cent said they had no idea whether or not the enterprises paid insurance for them. Consistent with the findings from Shanghai in terms of who is responsible for the individual's security and future life, Beijing people ranked the government first, the organisation second and the individual last to assume such a responsibility; this indicates a legacy from the command economy and the iron rice-bowl mentality. The Beijing study also found that more people purchased commercial insurances in 2002 than they did in 2001 (56 per cent compared to 38 per cent of people surveyed), especially medical insurance ( 35 per cent in 2002 compared to 14 per cent in 2001).

In closing this discussion of the literature, we suggest that the research on perception has shown that social protection is a major source of concern within China. What the literature also suggests is that there is diversity of perspective across gender, age and social stratum. What we shall do in the next section is determine if diversity of perspective can also be discerned from employees across firms characterized by different types of ownership and occupations.

As observed above, ownership is an issue that is very significant given that the development policies being furthered by the government are dramatically changing the ownership form of business enterprises within China.

\subsection{Research method}

This section is focused on the background of the survey conducted in 2002 in Shanghai, and the measures used in the survey questionnaire.

\subsubsection{Sample}

Our survey, based on a convenience sample, was conducted mainly in industrial enterprises in Shanghai in early 2002. Anonymous questionnaires were distributed to 650 respondents, from enterprises with different types of ownership. The response rate was 46 per cent with a total of 299 usable questionnaires received. Of the respondents, 32 per cent were from SOEs, 36 per cent from foreign invested enterprises (FIEs), 19 per cent from shareholding enterprises (SHEs), and 13 per cent from privately owned enterprises (POEs). 
Selected demographic characteristics of the respondents are shown in Table 9.3. Of the respondents, 60 per cent were male and 40 per cent female. The majority of respondents (60 per cent) were aged 30-50. Most were qualified, with 40 per cent having a tertiary diploma (equivalent to a TAFE diploma in Australia), and 28 per cent possessing a university graduate degree or higher. Over half (56 per cent) of the respondents were non-managerial staff (workers, technical, and clerical staff) and 44 per cent managerial employees (supervisors and managers at different levels).

Table 9.3 Profile of survey respondents

\begin{tabular}{ll}
\hline Variables & $\%$ \\
\hline Age $(N=277)$ & 15 \\
Under 30 & 21 \\
$30-39$ & 39 \\
$40-49$ & 24 \\
$50-59$ & 1 \\
60 and over & \\
\hline Gender (N = 266) & 40 \\
\hline Female & 60 \\
Male & 56 \\
Occupation (N = 268) & 44 \\
Non-managerial (workers, technical and clerical staff) & 32 \\
Managerial (supervisors and managers at different levels) & 40 \\
\hline Level of education (N = 267) & 25 \\
\hline High school certificate or less & 32 \\
Tertiary diploma (2-year university certificate, dazhuan) & 13 \\
Tertiary degree (4-year university Bachelor's degree, benke) & 36 \\
Post-graduate degree (Master degree or above) & 19 \\
\hline Ownership (N = 290) & \\
\hline State-owned enterprises (SOEs) & \\
Privately owned enterprises (POEs) & \\
Foreign-invested enterprises (FIEs) & \\
Shareholding enterprises (SHEs) & \\
\hline & \\
\hline
\end{tabular}




\subsubsection{Measures}

The survey requested data on the respondent's demographic characteristics, perceived changes in China's business environment, and his/her perception of the current social insurance policies. As recommended for international research (Cavusgil \& Das 1997), after the survey questionnaire was designed by the authors, it was translated and back-translated to check that the meaning of the original questions was intact.

Based on literature and the qualitative research conducted by Zhu et al. (Zhu and Nyland 2004; Zhu, Nyland \& Yang 2004), we developed scales measuring the perception of the changing business environment in China, enterprise competitiveness and attitudes towards social protection reform across dimensions of personal risk management/labour mobility, motivation/sense of security, role of trade unions and employee satisfaction. Respondents were asked to rate each item on a 5 -point scale from ' $1=$ strongly disagree' to ' $5=$ strongly agree,' with a neutral midpoint. We averaged the items on each dimension (possible score range is thus from 1 to 5 ) to form composite scales. A higher score on each scale indicates a greater amount of the variable being measured. Items related to these attitudinal dimensions are detailed below.

The changing business environment in China was measured by five items: (1) marketplace competition has increased dramatically from domestic competitors; (2) marketplace competition has increased dramatically from foreign competitors, (3) conditions in our business environment are rapidly changing; and (4) government intervention is rapidly declining and (5) the technology in our product/service is becoming more complicated. Scores on this scale had acceptable internal consistency with a Cronbach's alpha coefficient of .71.

Enterprise competitiveness was measured by four items: (1) social protection reform can help a company to focus on its economic activities and improve its competitiveness; (2) social protection reform will enable social insurance funds to be managed in a more efficient way; (3) current social protection system has speeded up the abolition of the iron rice-bowl system, and (4) social insurance policies have made welfare items transparent, which helps remove hidden costs paid by the enterprise. Cronbach's alpha for scores on this scale was .74.

Personal risk management/labour mobility was measured by three items: (1) as a 'social person', I can easily quit and look for better opportunities elsewhere; (2) now I can change my job more freely across different sectors based on my skills rather than the welfare offered by the firm; and (3) with new social insurance policies, I can better handle retrenchment as I may start my own business or get a job somewhere else. Cronbach's alpha coefficient for scores on this scale was .75 .

Motivation/sense of security was measured by two items: (1) I feel more motivated to work under the current social protection system than the previous welfare system, as I can rely less on the enterprise; and (2) my current personal insurance policy has increased my sense of security for my future retirement. Cronbach's alpha coefficient for scores on this scale was .72.

The role of trade unions was measured by three items: (1) it is necessary to have trade unions to facilitate social protection reform, as they will protect 
worker's rights; (2) trade unions have played an important role in the implementation of new social insurance policies; and (3) the supplementary medical insurance supplied by the Shanghai Workers' Mutual Association (SWMA, an organization of the trade unions) has reduced resistance to the implementation of new policy. Cronbach's alpha coefficient for scores on this scale was .68.

Finally, employee satisfaction with social protection policies was measured by eight items: satisfaction with the compulsory and supplementary pension policies, unemployment benefits, medical insurance policies for outpatients and inpatients, supplementary medical insurance, maternity insurance, and work injury compensation. Cronbach's alpha coefficient for scores on this scale was .90 .

\subsubsection{Control variables}

Organizational ownership was measured by four types of ownership (SOEs, POEs, FIEs, and SHEs). For multiple regression, ownership was coded as dummy variables; the omitted category was the modal category (FIEs). We controlled for age, gender, occupation (coded $1=$ manager, $0=$ non-manager), and education level ( 1 =high school or less, $4=$ postgraduate degree).

\subsection{Survey results}

The findings of this study are reported in two parts. First, we describe differences by ownership type and occupation on the measures of social protection reform. Second, multiple regression is used to examine determinants of employee satisfaction with social protection policies.

\subsubsection{Attitudes towards social protection}

Table 9.4 presents the mean scores for the attitude towards social protection measures across different ownership types. A series of one-way analyses of variance (ANOVAs) were conducted to detect statistically significant differences by ownership type. It found differences in employee attitudes across the four types of ownership with respect to (1) the changing business environment, (2) personal risk management/labour mobility, (3) the role of trade unions, (4) motivation/sense of security, and (5) satisfaction with social protection policies (see Table 9.4).

It can be seen that mean scores on each of the measures tended to be greater than the midpoint (neutral position) of the 5-point rating scale, indicating relatively positive attitudes towards social protection reform irrespective of ownership form. Nevertheless, Table 9.4 shows that employees in FIEs reported the highest ratings on the changing business environment (mean $=4.4)$. Post-hoc tests (Tukey) showed that employees in FIEs were more likely to report a changing business environment compared with employees in state, private or 


\section{Cherrie Jiuhua Zhu, Chris Nyland and Brian Cooper}

shareholding enterprises. Furthermore, post-hoc tests showed that respondents from FIEs were less likely to report the role of trade unions as a significant factor in social protection compared with state enterprises, which scored highest on the importance of the role of trade unions (mean $=3.1$ for FIEs and 3.7 for SOEs). Employees in private sector enterprises were significantly more likely to score higher on personal risk management/labour mobility compared with those in FIEs and SOEs (mean $=3.7$ for POEs, compared with 3.1 for FIEs and 3.3 for SOEs), indicating that employees in private firms were more likely to perceive themselves as 'social people'. Respondents from FIEs scored significantly lower on motivation/sense of security compared with respondents from POEs and SHEs (mean $=3.2$ for FIEs, compared with 3.7 for POEs and 3.6 for SHEs). Finally, post-hoc tests showed that employees from FIEs were the least satisfied with social protection policies compared with POEs and SHEs (mean $=2.8$ for FIEs, compared with 3.4 for POEs and 3.2 for SHEs).

The only scale in Table 9.4 which did not show statistically significant differences across the four types of ownership was 'enterprise competitiveness'. The total mean score of this scale was relatively high (mean $=3.6$ out of 5), indicating that social protection reform is perceived to have a positive impact on enterprise economic performance by survey respondents from different types of enterprises.

Table 9.4 Social protection measures by ownership

\begin{tabular}{|c|c|c|c|c|c|c|}
\hline Variable & $\begin{array}{l}\text { SOEs } \\
M \\
(S D) \\
\end{array}$ & $\begin{array}{l}\text { POES } \\
M \\
(S D) \\
\end{array}$ & $\begin{array}{l}\text { FIES } \\
M \\
(S D) \\
\end{array}$ & $\begin{array}{l}\text { SHES } \\
M \\
(S D) \\
\end{array}$ & $\begin{array}{l}\text { Total } \\
M \\
(S D) \\
\end{array}$ & ANOVA results \\
\hline $\begin{array}{l}\text { Changing business } \\
\text { environment }\end{array}$ & $\begin{array}{l}3.8 \\
(0.6)\end{array}$ & $\begin{array}{l}3.7 \\
(0.5)\end{array}$ & $\begin{array}{l}4.4 \\
(0.4)\end{array}$ & $\begin{array}{l}3.9 \\
(0.4)\end{array}$ & $\begin{array}{l}4.0 \\
(0.5)\end{array}$ & $\mathrm{F}(3,277)=30.3^{* * *}$ \\
\hline $\begin{array}{l}\text { Enterprise } \\
\text { competitiveness }\end{array}$ & $\begin{array}{l}3.7 \\
(0.7)\end{array}$ & $\begin{array}{l}3.6 \\
(0.6)\end{array}$ & $\begin{array}{l}3.5 \\
(0.6)\end{array}$ & $\begin{array}{l}3.6 \\
(0.5)\end{array}$ & $\begin{array}{l}3.6 \\
(0.6)\end{array}$ & $F(3,281)=1.2$ \\
\hline Role of trade unions & $\begin{array}{l}3.7 \\
(0.7)\end{array}$ & $\begin{array}{l}3.5 \\
(0.6)\end{array}$ & $\begin{array}{l}3.1 \\
(0.5)\end{array}$ & $\begin{array}{l}3.6 \\
(0.4)\end{array}$ & $\begin{array}{l}3.6 \\
(0.7)\end{array}$ & $\mathrm{F}(3,279)=14.4^{* * *}$ \\
\hline $\begin{array}{l}\text { Personal risk } \\
\text { management/labour } \\
\text { mobility }\end{array}$ & $\begin{array}{l}3.3 \\
(0.9)\end{array}$ & $\begin{array}{l}3.7 \\
(0.7)\end{array}$ & $\begin{array}{l}3.1 \\
(0.8)\end{array}$ & $\begin{array}{l}3.5 \\
(0.6)\end{array}$ & $\begin{array}{l}3.3 \\
(0.8)\end{array}$ & $\mathrm{F}(3,282)=7.2 * * *$ \\
\hline $\begin{array}{l}\text { Motivation/sense of } \\
\text { security }\end{array}$ & $\begin{array}{l}3.5 \\
(0.8)\end{array}$ & $\begin{array}{l}3.7 \\
(0.7)\end{array}$ & $\begin{array}{l}3.2 \\
(0.9)\end{array}$ & $\begin{array}{l}3.6 \\
(0.5)\end{array}$ & $\begin{array}{l}3.5 \\
(0.8)\end{array}$ & $\mathrm{F}(3,277)=5.4 * * *$ \\
\hline Satisfaction & $\begin{array}{l}3.1 \\
(0.7)\end{array}$ & $\begin{array}{l}3.4 \\
(0.6)\end{array}$ & $\begin{array}{l}2.8 \\
(0.6)\end{array}$ & $\begin{array}{l}3.2 \\
(0.4)\end{array}$ & $\begin{array}{l}3.1 \\
(0.6)\end{array}$ & $\mathrm{F}(3,279)=10.1 * * *$ \\
\hline $\begin{array}{l}\text { Notes } \\
* \mathrm{p}<.05 \\
* * \mathrm{p}<.01 \\
* * * \mathrm{p}<.001\end{array}$ & & & & & & \\
\hline
\end{tabular}


Table 9.5 Social protection measures by occupation

\begin{tabular}{|c|c|c|c|}
\hline Variable & $\begin{array}{l}\text { Non-Managerial } \\
M \\
(S D) \\
\end{array}$ & $\begin{array}{l}\text { Managerial } \\
M \\
(S D) \\
\end{array}$ & $t$-value \\
\hline $\begin{array}{l}\text { Changing business } \\
\text { environment }\end{array}$ & $\begin{array}{l}3.9 \\
(0.5)\end{array}$ & $\begin{array}{l}3.8 \\
(0.5)\end{array}$ & $t(254)=1.9$ \\
\hline Enterprise competitiveness & $\begin{array}{l}3.7 \\
(0.6)\end{array}$ & $\begin{array}{l}3.6 \\
(0.6)\end{array}$ & $t(263)=0.6$ \\
\hline Role of trade unions & $\begin{array}{l}3.5 \\
(0.8)\end{array}$ & $\begin{array}{l}3.4 \\
(0.7)\end{array}$ & $t(263)=0.2$ \\
\hline $\begin{array}{l}\text { Personal risk } \\
\text { management/labour } \\
\text { mobility }\end{array}$ & $\begin{array}{l}3.3 \\
(0.8)\end{array}$ & $\begin{array}{l}3.4 \\
(0.7)\end{array}$ & $t(263)=-1.4$ \\
\hline $\begin{array}{l}\text { Motivation/sense of } \\
\text { security }\end{array}$ & $\begin{array}{l}3.5 \\
(0.7)\end{array}$ & $\begin{array}{l}3.5 \\
(0.8)\end{array}$ & $t(263)=0.6$ \\
\hline Satisfaction & $\begin{array}{l}3.0 \\
(0.6)\end{array}$ & $\begin{array}{l}3.1 \\
(0.7)\end{array}$ & $t(259)=-1.2$ \\
\hline \multicolumn{4}{|l|}{ Notes } \\
\hline \multicolumn{4}{|l|}{$* \mathrm{p}<.05$} \\
\hline \multicolumn{4}{|l|}{$* * \mathrm{p}<.01$} \\
\hline$* * * \mathrm{p}<.001$ & & & \\
\hline
\end{tabular}

Table 9.5 presents mean scores for the perception of social protection measures by occupation. A series of independent samples t-tests were conducted to detect any statistically significant differences between managerial and nonmanagerial employees. There were no statistically significant differences according to occupation.

\subsubsection{Determinants of employee satisfaction with social protection policies}

We then conducted a multiple regression analysis using employee satisfaction with social protection policies as the dependent variable. Satisfaction was regressed onto the variables of changing business environment, the attitudinal measures outlined above, ownership type, age, gender, occupation, and educational level. The relationships were tested using multiple regression to control for variables simultaneously and to take into account the interrelationships among the independent variables. Regression allows us to estimate the 'unique' contribution of each independent variable to the model after controlling for all other independent variables in the model. Colinearity diagnostics using the Tolerance Test indicated that the regression coefficients were not degraded by multicolinearity. Pairwise deletion was used for missing 


\section{Cherrie Jiuhua Zhu, Chris Nyland and Brian Cooper}

data. There were no consequential departures from normality, linearity and homoscedasticity.

Table 9.6 presents the results of the multiple regression analysis. Overall, the regression model accounted for a modest 26 per cent of the variation in employee satisfaction. Four variables were significant in the prediction of satisfaction. There was a positive relationship between motivation/sense of security and satisfaction (Beta $=.29, \mathrm{p}<.001)$. Respondents who felt increased motivation/sense of security under the current social protection were more likely to be satisfied. Compared with respondents from FIEs, private sector (Beta = $.22, \mathrm{p}<.01)$ and shareholding (Beta $=.14, \mathrm{p}<.05$ ) employees were also more likely to be satisfied. There was a positive relationship between attitudes towards the role of trade unions in social protection reform and satisfaction (Beta $=.21, \mathrm{p}<01$ ); that is, respondents who reported positive attitudes to the role of trade unions were more satisfied with social protection policies. These effects control for age, gender, education level, and occupation, noting that their unique effects were not, however, statistically significant.

Table 9.6 Multiple regression analysis of independent variables on satisfaction with social protection policies

\begin{tabular}{lcc}
\hline & \multicolumn{2}{c}{ Standardized (Beta) regression coefficient } \\
\hline Age & -0.00 & $(0.04)$ \\
Gender & 0.00 & $(0.07)$ \\
Occupation & 0.04 & $(0.70)$ \\
Education level & -0.07 & $(-1.10)$ \\
Changing business environment & 0.10 & $(1.45)$ \\
State & 0.07 & $(0.10)$ \\
Private & 0.22 & $(3.03)^{* *}$ \\
Shareholding & 0.14 & $(1.97)^{*}$ \\
Competitiveness & -0.07 & $(-0.94)$ \\
Role of trade unions & 0.21 & $(2.72)^{* *}$ \\
Personal risk management/labour mobility & 0.07 & $(1.11)$ \\
Motivation/security & 0.29 & $(4.00)^{* * *}$ \\
$\mathrm{R}^{2}$ (explained variance) & 0.26 & \\
\hline Notes & & \\
$\mathrm{t}-$ values in parentheses. & & \\
${ }^{*} \mathrm{p}<.05$. & & \\
$* *$ p $<.01$ & & \\
$* * * \mathrm{p}<.001$ & &
\end{tabular}




\subsection{Discussion and conclusion}

Based on the survey results, it is evident that ownership form has a significant impact on employee perception of social protection reform. Despite the fact that the mean ratings indicated relatively positive attitudes towards social protection reform across ownership form, the results revealed that employees from FIEs displayed the least positive attitude towards personal risk management/labour mobility, the role of trade unions, motivation/sense of security and satisfaction with social insurance policies. By contrast, those from POEs tended to have a more positive attitude in response to these issues. Employees from POEs perceived their ability to deal with personal risk and job changes under the new security system in a more positive way than those from FIEs and SOEs. This not only demonstrates that employees of POEs were more likely to perceive themselves as 'social people', but also indicates that social insurance might be the only welfare they can enjoy and thus becomes a major concern when they relocate across enterprises.

By contrast, employees from SOEs used to enjoy more welfare benefits such as housing and other free or subsidized services (for example child care, education and public health) in addition to social insurance. This might explain why SOE people often regarded themselves as 'unit people', as they rely heavily on their work unit for most welfare needs. The written comments made by three respondents on the survey questionnaire all pointed out that the current social security system did not provide adequate security for SOE employees to enable 'social people' to face the challenges of a free market. There are mixed reasons why FIE respondents scored lowest on personal risk management/labour mobility. Some FIEs (which were joint ventures formed with SOEs and influenced/controlled by the Chinese partner) offered welfare benefits to their employees that were similar to those in SOEs, which made their employees rely more on the 'work unit'. Some FIEs, especially those established by multinationals from advanced market economies, might transfer their home country's 'best practices' in workforce management (Chan 2001) and offer their employees more benefits (both tangible and intangible, such as better salary and learning environment) than merely social insurance. In this case, employees would not consider social security alone as an important factor for them to change jobs. In contrast, employees from POEs previously had little social protection and are therefore most satisfied and motivated by the new social security system. These results support our claim that the establishment of a social protection system could heighten the security enjoyed by the increasing number of employees working in the non-state sector.

Why were respondents from FIEs less motivated by and satisfied with the new social protection system than those from POEs? There could be several reasons. First, FIEs in Shanghai, whether joint venture or wholly foreign owned, all have to supply basic social insurance provisions to their employees as required by law. The only matter of choice for FIEs is whether or not to supply supplementary insurance. Although POEs are supposed to have the same requirement, the tendency for them to act as free rider (that is to evade social insurance payment) seems more apparent (see Zhu and Nyland 2004). One 


\section{Cherrie Jiuhua Zhu, Chris Nyland and Brian Cooper}

respondent commented at the end of the survey that one of the problems with the system was that many POEs simply ignored the new social security policies. This might explain why employees of POEs appreciate any social protection they do receive. Furthermore, FIE employees were normally better paid than their counterparts in POEs. It was officially reported that the average salary level for employees in Shanghai in 2001 was 17,820 RMB for SOEs, 20,865 RMB for POEs, and 24,352 RMB for FIEs (Shanghai Statistical Almanac 2002). In addition to a much higher income, FIE employees may also receive other types of incentive such as housing allotments and stock options (see Hickey 2003; Zhao 2003; and case study 3 in Zhu and Nyland 2004). With all these attractive benefits that employees can receive, social insurance pales in significance to FIE employees. Another reason behind the differences between FIEs and POEs could be a more formal human resources management system practised in FIEs. As researchers have pointed out, 'joint venture firms in general adopted more market-oriented approaches in managing human resources and in designing social security schemes' (Ding et al 2000: 224). More formal HR practices to attract, develop and retain employees would tend to reduce employees' anxiety about retrenchment or welfare post retirement.

In terms of the role of trade unions in social protection, it was not surprising that respondents from SOEs scored the highest. Traditionally only permanent employees could join unions in China (Warner 1995). SOEs had more permanent employees than other types of enterprises, and these employees were automatically accepted and looked after by the unions. Trade unions are not mandatory in the private sector, although the Labour Law has legitimized labourers' right to form and participate in trade unions. The survey results have also supported our claim in another paper (see Zhu et al 2004) that trade unions in SOEs were still playing the role of a caretaker that helped the government and enterprise management to implement the new social insurance policies which have greatly increased individual's contribution to the new system. This has especially been the case in Shanghai, where most SOEs have joined the supplementary medical insurance schemes established and managed by Shanghai Workers Mutual Association (SWMA, an agency of the trade unions) as SOEs generally had a lower salary level with an ageing workforce. Compared with SOEs, FIE employees were much better paid (the average salary of FIEs was nearly 37 per cent higher than that of SOEs, Shanghai Statistical Almanac 2002), and therefore more capable of paying the social insurance fees. FIEs also had a much younger workforce with less medical expenses (see cases 3 and 4 in Zhu and Nyland 2004). Instead of using SWMA's additional insurance package (which must be purchased for every employee of the firm), FIEs prefer to have commercial insurance. In such circumstances, FIEs relied much less on trade unions to help their employees cope with social insurance reform. This may explain why FIEs scored the lowest for the role of trade unions.

With regard to the changing business environment, FIEs experienced a series of changes in the late 1990s and early 2000 when the government waived some preferential treatments that had previously been offered to encourage the development of private businesses, such as tax holidays enjoyed by FIEs and the acceptance of POEs' paying less or no social security benefits to their 
employees. Furthermore, with accession to the WTO, FIEs are faced with more competition from both international and domestic markets than other types of enterprises because of their export activities. This could explain why FIE respondents were more likely to report a rapidly changing business environment.

Interestingly, the scale measuring enterprise competitiveness received positive feedback (overall sample mean $=3.6$ out of 5 ) with no statistically significant differences across ownership types; this indicates that the new social protection system was perceived positively by respondents in its ability to facilitate the firm's business operation in a market-driven economy and to manage the system in a more efficient way.

The statistically significant survey results were translated into determinants of employee satisfaction with the new social protection system. These included sense of security, ownership type and the role of trade unions. Respondents who felt that they could rely less on their enterprises and more on the social protection system to achieve a sense of security about their future retirement were more likely to be satisfied with the new system. Compared with respondents from FIEs, those from POEs and SHEs were more satisfied with the social protection system. In other words, the newly established social protection system could encourage people to move into or stay in POEs or SHEs. Furthermore, respondents who perceived that trade unions could play an important role in the implementation of social protection policies tended to be more satisfied with the system.

In this chapter we have focused on the perceptions of both managerial and non-managerial employees from different types of enterprises towards the social protection reform in Shanghai. There are limitations to the study, particularly in the use of convenience sampling (which limits the generalizability of the survey findings) and our reliance on self-report rating scales (which can be subject to error and response bias). Nevertheless, we have found that occupation did not have a statistically significant impact on employees' attitudes towards reform, although ownership type did have an impact. Some useful implications can be drawn from the findings for further discussion. The first and unavoidable implication is that the government has to take steps to ensure that all enterprises meet insurance obligations, as the sense of security offered by each enterprise is an important determinant of employee satisfaction with the social security system. Moreover, the government needs to ensure that the implementation of the policies of 'Two Guarantees' and 'Three Security Lines' needs to cater not only for the workers' basic needs when they exit the labour market, but also to encourage them to resist exploitation and risk a greater level of entrepreneurship, that is to be real 'social people'. ${ }^{1}$ Furthermore, the trade unions should be encouraged to take a leading role in the implementation of social security policies, as this may have a significant long-term impact on the viability of the union movement, on the nature of labour market relations, and on the willingness of workers to embrace the reforms. While the new social security system does have a positive impact on work incentives and labour mobility, its negative effect on job security and labour market equality should not be dismissed. The establishment of the social security system has enhanced the capacity of employers to retrench workers, and the new regulations are often 


\section{Cherrie Jiuhua Zhu, Chris Nyland and Brian Cooper}

under-enforced. Therefore, the transition from a 'unit person' or 'labour aristocrat' to a 'social person' or 'labourer in a free market' needs to be facilitated by the government, management and trade unions in ways that will help employees deal with the challenges associated with such a transition while maintaining their sense of security in the system.

\section{Notes}

1 The 'Two Guarantees' policy guarantees the basic living standard of retrenched workers from SOEs and the timely and full payment of basic pension benefits to retirees from enterprises, while the 'Three Security Lines' refers to (1) the basic living standard guarantee system for people laid off from SOEs; (2) the unemployment insurance system targeted at the unemployed, and (3) the minimum living standard guarantee system of urban residents whose family income per capita is lower than the prescribed level. 


\title{
10 Pension reform in China: imperatives, constraints and outcomes
}

\author{
Peter Saunders and Lujun Sun *
}

\subsection{Introduction}

China is in the midst of a major transition from a centrally planned to a more market-oriented economy, and from a predominantly rural to a more urbanized society. This is occurring as its national income is growing strongly and as its population is ageing very rapidly (Whiteford 2003). There is great interest in the impact of these changes on the living standards of the population and on the extent and nature of poverty and inequality. In addition, the sheer size of China's economy and population guarantees that these changes will have a major impact on how the global economy is affected by changes in trade liberalization, market competition and other factors.

The combination of the 'one-child family' policy and increased longevity is seeing a very rapid ageing of the Chinese population. As the World Bank has noted:

By 2030 the absolute size of the labour force in China will begin to decline, and by 2050 the ratio of workers to pensioners (aged sixty-five and above) is projected to decline to about 3 to 1 from the 10 to 1 ratio in 1995. The number of elderly will rise from about 76 million in 1995 to 300 million by 2050 .

(World Bank 1997c: 1)

The demographic transition is expected to accelerate rapidly after 2010 , as the dependency ratio rises, placing enormous pressure on the authorities to introduce pension reforms capable of supporting the growing number of aged people at a level that is consistent with the increase in material prosperity that is taking place generally.

At the same time, China is undergoing a series of other transitions, including the shift from a centrally planned to a 'socialized market economy', from a lowincome to a middle-income country, and from a rural and agricultural to an urbanized and industrialized society. These changes are affecting the traditional structure of Chinese society and the role of its institutions. Much emphasis has been placed on the ability of formal institutional structures to respond to these changes and the role of policy in the adjustment process. But the process of 


\section{Peter Saunders and Lujun Sun}

reform of formal institutions cannot take place without affecting the role and nature of the many informal structures that are also part of the overall institutional framework of any society. These changes need to be considered as part of the reform process, since the role of informal institutions is also changing in ways that will have an important bearing on how well formal structures can respond to the challenges they face. For this reason, it is important to focus on both formal and informal institutional structures when considering the capacity for change and the constraints this imposes on reform and its outcomes.

As with other developing countries, China's social protection system has traditionally relied upon a network of formal and informal structures and arrangements that reflect its history and culture. Global economic developments pose a challenge to the values and attitudes that underlie these informal structures, but their importance cannot simply be ignored. Nowhere is this more relevant than in relation to the reform of social policies and the impact of public programs on the living conditions of the aged. Western experience has shown that one of the crowning achievements of the post-war welfare state (still supported by even the most conservative of governments) is the maintenance of living standards in old age through a range of pension, health, housing and community support programs. The success of social policy in countries like China will be judged by how well it protects the living standards of its older citizens - as is well understood by those driving the reform agenda. But how well this is achieved will depend not only on the efficacy of public programs important though these are - but also on how well the reforms can be integrated with the informal structures of support that currently exist. The values and practices of that informal support system are often viewed with envy by Western countries where they have been replaced by formal programs, and part of the challenge for countries like China is to ensure that reform of the formal structures does not weaken the informal structures that economic reforms are already placing under stress.

As a contribution to this task, this chapter reports some early results from a project that is examining the living standards of the aged in China in 2000 and how they have changed since 1992. The period covered has been characterized by rapid and extensive reform of policies affecting the aged, and part of our goal is to investigate what effect these have had on the economic status of older people, the role played by the family in this context, and how attitudes have changed towards these issues. The chapter focuses on the role of pensions in providing income support for the aged, how this has changed, and its impact and consequences for support provided by family members. It is hoped that the results presented will illustrate the importance of looking beyond pensions (and by implication, beyond pension reform) in understanding the factors that contribute to wellbeing in old age and the opportunities to influence it.

It is worth emphasizing at the outset that though the chapter may appear to have little to do with the general focus of this volume on institutional change and its implications for the business sector, this is not in fact the case. One of the most important institutions in all societies is the family, and part of the challenge facing policymakers in China revolves around how to restructure public policy to respond to the transitions underway without at the same time undermining the 
role the family plays in Chinese society. The results presented demonstrate that the family plays an integral role in supporting the aged, and this has implications for the nature (and pace) of pension reform. In addition, while business has tended to focus on how pension and other reforms will affect its cost structure, this too must take account of the costs and benefits associated with the informal system of social support. The imposition of additional costs on business will be accompanied by reduced demands on workers to provide family support, and the effects of this need to be brought into the overall calculus. Although the chapter does not explicitly address these issues, the results will draw attention to the importance of them and, it is hoped, prompt others to revise their thinking accordingly.

The chapter is organized as follows: Section 10.2 provides a brief overview of recent pension reforms in China and the response to them by analysts. Section 10.3 provides a similarly brief introduction to the data used and the survey from which they were derived. Section 10.4 reviews some of the objective and subjective data on the living conditions and circumstances of the aged, including how these have changed between 1992 and 2000. Section 10.5 examines the changing nature of attitudes to support among the aged and the role of informal intra-family transfers. Most of the results cover the urban aged only, although we also present some rural results for purposes of comparison. Our main conclusions are briefly summarized in Section 10.6.

\subsection{Reviewing recent pension reforms}

It was inevitable that the combination of a rapidly ageing of its population and its sheer size would make pension reform in China the focus of intense interest from around the world. The World Bank has played a major role in highlighting the problems and developing solutions: thus, in its 1997 report on Old Age Security. Pension Reform in China, it was argued that 'the problems of the current system of pensions in China are deep-seated and widely recognized' but that 'the broad directions of reform are becoming clear' (World Bank 1997c: 4). Yet despite major reforms introduced in 1997 and 2001 (see below), there remains concern that the reforms to date have not addressed all of the underlying problems. Thus Estelle James, a leading contributor to the 'three pillar' model of income support in retirement developed by the World Bank (1994), has described pension reform in China as being 'characterized by bold pronouncements followed by cautious implementation as the new problems emerge. On a year-to-year basis it has sometimes been difficult to see any change, despite the great changes on paper' (James 2001: 73).

In a similar vein, Pieter Bottelier who has been heavily involved in the World Bank's work on pension reform in China has recently described the current system as 'under-funded, fragmented, incomplete in coverage and uneven in regard to benefits' (Bottelier, 2003). However, he goes on to argue that 'China is essentially on the right track towards creating a modern pension system that is compatible with the requirements of an aging population in a market economy. It would have been a miracle if there had been no implementation problems. We 


\section{Peter Saunders and Lujun Sun}

should not forget that the social security reform challenges facing China are unprecedented in scale and complexity.' (Bottelier 2003:32).

The foundations of the new pension system were set in place by the 1997 reforms which established a two-tier public pension system consisting of a basic, universal social pooling component, supplemented by a contributory pension funded from individual accounts (Whiteford 2003; Zhu 2002). The new scheme provides a social pooling pension set at 20 per cent of the average regional wage, with the individual account component providing an additional pension up to a maximum of 38.5 per cent of the average wage after 35 years of contribution. The original idea was that the individual account component would be fully funded by contributions from employers and employees, although the formula used to estimate the benefit was set too generously, creating problems from the outset in terms of financial sustainability.

These design problems were compounded by the fact that in practice, contributions into individual accounts have been used to pay for the social pooling pensions, making the individual accounts an accounting exercise and leaving the entire system running on a pay-as-you-go (PAYG) basis. Furthermore, the implied rate of return on contributions to the individual accounts has been set very low (by administrative fiat), reducing the incentive for firms (and their employees) to join the scheme (James 2001). The consequence has been low coverage which, when combined with the rapid growth in the number of pensioners, has further undermined the financial soundness of the whole system. For example, Whiteford (2003) reports that while the number of contributing workers doubled from 52 million to 104 million between 1990 and 2000 (equivalent to an annual growth rate of 7.2 per cent), the number of pensioners rose from 10 million to 32 million, an annual increase of 12.3 per cent. Put differently, the ratio of worker/contributors to pensioner/beneficiaries declined from 5.2 in 1990 to 3.25 in 2000 .

These problems have been compounded by the fact that the scheme is run on a highly fragmented basis at the local/provincial level. This has resulted in different contribution rates in different places, creating economic distortions. In addition, since the central government has bailed out several local pension pools that have become bankrupt, there is little incentive for local scheme managers to ensure the financial soundness of local schemes, creating an additional barrier to an extension of coverage. In 2001, a pilot scheme was established in Liaoning Province in which the management of individual accounts has been segregated from the administration of social pooling funds in an attempt to overcome some of the current difficulties. While this initiative is being watched with interest, it has not resolved the problems associated with the complexity of transferring between local schemes, which is seen as an obstacle to labour mobility (Zhao and $\mathrm{Xu}$ 2002: 399). The fragmentation issue is also being addressed by the National Social Security Fund (NSSF), established in 2000, which is attempting to unify the system by receiving revenues from government and other sources that can be used to cover revenue shortfalls at the local level (James 2001).

Despite all of the changes so far brought about, it seems clear that yet more reforms to China's formal pension system will be required. Much of the discussion, however, has taken place in isolation from the broader system of 
support for the aged, much of which is still provided from within the family. Whiteford (2003: 74) comes close to acknowledging this omission by ending his analysis with the statement that 'attention needs to be given to the development of more balanced social protection policies to address the needs of the majority of the Chinese population'. But even here there is inadequate attention to the need to address the role of informal support mechanisms for the aged, including their response to changes in formal policy structures.

But welfare state scholars have long argued that, particularly in East Asian countries, the inter-relationship between formal and informal provision is central to understanding the nature of social policy in the region. Thus, White and Goodman (1998: 13-14) identify an East Asian 'welfare orientalism' model in which:

The notion of state-provided or guaranteed welfare as a social right of citizens is weakly developed. Rather, non-state agencies - community, firm and family - have been expected to play a major role in both financing and providing welfare services in an ideological context wherein self/mutual help is encouraged and dependence on the state discouraged, indeed stigmatized.

And in his own analysis of social security reform in China, White (1998: 176) argues that:

(W)elfare reforms cannot be seen merely in terms of choices between alternative policy options or directions; rather, the range, nature and feasibility of these choices are heavily determined by deeper dynamics which are propelled not only by broad structural changes in the social, political and economic spheres, but also by the particular constellation of interests ands perspectives which cluster around welfare issues like iron filings round a magnet.

One example illustrates the importance of adopting this broad approach (and the expanded notion of institutions that it implies) in the context of pension reform. One of the challenges facing China currently is the so-called 'double burden' dilemma, whereby the current generation is required to pay not only for their own future pensions, but also to finance the pensions paid to the current generation of retirees. All funded pension systems (of which the principle of individual accounts is an example) must face this dilemma, which represents a major transition issue. In the pension reform literature, the double burden dilemma is seen as imposing constraints on how quickly a defined-contribution, fully funded pension scheme can be introduced.

However, the counterpart to the formal double burden imposed on the current generation of workers is a greatly reduced expectation among the current generation of retirees regarding how much they can expect to receive by way of informal intra-family transfers. A rational (in most cases, enforced) response to the introduction of a pension double burden is for workers to reduce their other financial commitments - one of which is likely to be transfers to older family 


\section{Peter Saunders and Lujun Sun}

members. This suggests that the outcomes of pension reforms of the type being implemented in China cannot be analysed without taking account of these consequences for private intra-family transfers. At the very least, there is a need to examine the extent to which the promise of within-family support (previously seen as virtually guaranteed within towns and villages) has been replaced by greater uncertainty as the terms of the formal inter-generational contract are being rewritten in the policy ministries in Beijing. By focusing on these issues, this chapter will hopefully provide same balance to what has to date been a rather narrow pension reform debate.

\subsection{Data}

In order to provide basic data needed to evaluate the total ageing situation and to better understand the circumstances of the aged population, the Sample Survey of the Aged Population in Urban and Rural China was undertaken in December 2000, sponsored by the All China National Working Commission on Ageing, the China National Committee on Ageing (CNCA) and the China Research Centre on Ageing (CRCA). The broad structure of the survey instrument replicates an earlier survey that was also undertaken in 1992 by CNCA and CRCA that covers many similar topics, although the earlier survey was restricted to only twelve provinces (CRCA 1994). Both surveys were undertaken in coordination with local committees on ageing in the selected provinces, municipalities and autonomous regions.

The latest survey adopted a stratified sampling method which operated at five levels. First, 20 provinces were chosen from 30 candidate regions; second, four cities and four counties were chosen in each selected province, divided into urban and rural areas; third, 16 resident districts (urban) and 16 towns (rural) were chosen in each selected city/county; fourth, 50 resident committees (urban) and 50 village committees (rural) were chosen from those included at the third level; and finally, 10 'elderly households' (each with at least one family member aged 60 or above) were chosen from each resident committee or village committee at the fourth level.

The 2000 survey contains 10,249 respondents from urban areas and 10,299 from rural areas, and involved over 2000 interviewers. A separate community questionnaire was also administered in each of the 80 cities and 80 counties included in the second level of sampling, although that information is not examined here. In overall terms, the demographic coverage of the 2000 survey was 935 million, accounting for 72.2 per cent of the total population of the country. The survey date (1 December 2000) is close to the date of the Fifth National Census (conducted on 1 November), and data from the census have been used to derive a set of weights that have been applied to the survey data described and analysed below.

Most of the results refer only to the urban aged population in 2000, although some comparisons are made with the rural population in that year and, where the data permit, changes between 1992 and 2000 are discussed. However, the precise wording of many of the questions has changed or been expanded to 
reflect new areas of interest, so that there are relatively few areas where a direct comparisons of responses is possible. Another important feature of the data is that they relate primarily to the respondent only, with relatively little information provided about other co-habiting family members (including other aged people). This is a limitation since, as will be shown below, the incidence of co-habitation is very high. There are, however, a number of attitudinal questions that allow the attitudes of the aged in 2000 to be analysed and compared in some instances with those prevailing in 1992. As shown in the previous section, the intervening period was characterized by major reforms to the pension system, so it is of great interest to explore whether this has affected the values, attitudes and expectations of the aged.

Finally, it is important to stress that the results reported below are preliminary and subject to revision as the analysis proceeds. The research team (consisting of Saunders and Xiaoyuan Shang at SPRC and Zhang Kaiti, Sun Lujun, Guo Ping and Chen Gang at CRCA) are still in the early stages of the analysis, and this should be kept in mind.

\subsection{The well-being of the aged: objective and subjective indicators}

We begin by presenting results on the living arrangements of the urban aged because housing represents an important aspect of the overall living conditions of the aged. One of the reasons, for example, why the age pension in Australia is so low relative to average community incomes compared with other OECD countries is that home ownership is heavily subsidized by government and home ownership rates are consequently high. In many developing countries, shared housing is a way of spreading costs between generations and is thus part of the overall support system. In countries like China, in particular, the state has played a direct role in housing provision and many people live in government-owned residences and face very low housing costs.

\subsubsection{Living arrangements}

Table 10.1 provides a breakdown by age and gender of the 2000 sample of the urban aged, classified according to whether they live alone or with their spouse only, with other relatives, or with unrelated people. ${ }^{1}$ Overall, around 60 per cent of the aged live with someone other than their spouse. Of those who do not live with others, about 10 per cent live alone, and a further 30 per cent with their spouse - with far more women living alone and far more men living with their partner (reflecting the increased longevity of women). Very few of the aged live with people to whom they are not related, but the fact that so many do live with relatives implies that the average household size for households that contain at least one aged person is 3.3 - well in excess of the corresponding value in a country like Australia. This implies that the economic circumstances of the other family members with whom aged people live and the degree to which there is resource sharing within the household will both have a critical bearing on the economic wellbeing of the aged. 


\section{Peter Saunders and Lujun Sun}

The patterns of living arrangements in 1992 for the provinces/cities included in that survey are very similar to those shown in Table 10.1 and are therefore not shown separately. ${ }^{2}$ Thus for example the percentages of aged persons in all age groups in each of the three identified living-arrangement categories in 1992 was 40.7 per cent, 58.9 per cent and 0.4 per cent - very close to the 2000 estimates shown in Table 10.1. These similarities remain across all age and gender classifications.

Table 10.1 Living arrangements among the urban aged in China in 2000 (percentages)

\begin{tabular}{|c|c|c|c|c|c|c|}
\hline \multirow[b]{2}{*}{ Living Arrangements: } & Age: & & & Total: & & \multirow[b]{2}{*}{$\begin{array}{l}\text { Average } \\
\text { household } \\
\text { size }\end{array}$} \\
\hline & $60-69$ & $70-79$ & $80+$ & $(' 000)$ & $(\%)$ & \\
\hline & \multicolumn{6}{|c|}{ MALES: } \\
\hline $\begin{array}{l}\text { Living alone or with } \\
\text { spouse }\end{array}$ & 24.5 & 17.2 & 2.5 & 6295.9 & 21.4 & 1.9 \\
\hline Living with relatives & 35.9 & 15.4 & 3.8 & 7825.7 & 26.6 & 4.4 \\
\hline $\begin{array}{l}\text { Living with unrelated } \\
\text { people }\end{array}$ & 0.3 & 0.4 & 0.0 & 88.3 & 0.3 & 3.0 \\
\hline \multirow[t]{2}{*}{ Total } & 60.7 & 33.0 & 6.4 & 14209.9 & 48.3 & 3.3 \\
\hline & \multicolumn{6}{|c|}{ FEMALES: } \\
\hline $\begin{array}{l}\text { Living alone or with } \\
\text { spouse }\end{array}$ & 21.4 & 12.5 & 2.9 & 5589.8 & 19.0 & 1.6 \\
\hline Living with relatives & 34.9 & 20.2 & 6.8 & 9414.4 & 32.2 & 4.2 \\
\hline $\begin{array}{l}\text { Living with unrelated } \\
\text { people }\end{array}$ & 0.5 & 0.4 & 0.3 & 205.9 & 0.7 & 2.5 \\
\hline \multirow[t]{2}{*}{ Total } & 56.9 & 33.1 & 10.1 & 15210.1 & 51.7 & 3.2 \\
\hline & \multicolumn{6}{|c|}{ PERSONS: } \\
\hline $\begin{array}{l}\text { Living alone or with } \\
\text { spouse }\end{array}$ & 22.9 & 14.7 & 2.7 & 11873.9 & 40.4 & 1.7 \\
\hline Living with relatives & 35.4 & 17.9 & 5.4 & 17254.0 & 58.6 & 4.3 \\
\hline $\begin{array}{l}\text { Living with unrelated } \\
\text { people }\end{array}$ & 0.4 & 0.4 & 0.2 & 292.1 & 1.0 & 2.6 \\
\hline Total & 58.7 & 33.0 & 8.3 & 29420.0 & 100.0 & 3.3 \\
\hline
\end{tabular}

Survey estimates have been weighted to the population using data from the 2000 Census. 


\subsubsection{Mean incomes}

Table 10.2 shows the mean reported incomes of the aged, disaggregated by age, gender and living arrangements (see Table 10.1). ${ }^{3}$ Income has been separated into market income from earnings, self-employment and investments (including dividend and rental income), transfer income in the form of pension and other public and private transfers, and other sources of income. The most striking feature of these results is the sharp gender differences in mean incomes in both years: in 2000 , for example, across all age ranges, the mean income of women is only just over half ( 57.8 per cent) of that of men, and this relativity declines with age, as women's incomes decline more rapidly than men's. In 1992, after adjusting mean incomes to reflect year 2000 consumer prices, ${ }^{4}$ the overall ratio of female to male incomes was $\mathbf{5 7 . 2}$ per cent, implying that there has been no change in the female to male income differential over the period, despite the growing importance of pension income.

In both years, transfers were the main source of income overall, accounting for around 86 per cent of total income in both years. Pensions were the major source of income for both men and women in both years, accounting for 78 per cent of total male income and 71 per cent of female income in 2000. The importance of pension income tends to increase with age for men but declines for women; even so, pensions contribute a greater percentage to total income for men than for women at all ages. The importance of pension income increased substantially for both men and women over the period, this shift being accompanied by a decline in the importance of income from other public transfers and from private transfers. In 1992, these two forms of non-pension transfers accounted together for over 33 per cent of average male income and 53 per cent of average female income; by 2000 , these percentages had declined to close to 7 per cent (males) and 16 per cent (females), respectively.

Table 10.2 also shows that real (CPI-adjusted) incomes grew very significantly for aged men and women in all age groups between 1992 and 2000. For men in their sixties, seventies and over- 80 , the real increases in mean income were 94 per cent, 104 per cent and 96 per cent respectively, while the average increase for men of all ages was 94.7 per cent. The corresponding increases for women of different ages are even greater, at 280 per cent, 56 per cent and 77 per cent respectively, with an overall increase of 97 per cent. Thus real incomes almost more than doubled on average, implying a considerable improvement in living standards - albeit accompanied by no change in the gender income gap. Similarly dramatic real income increases are apparent for 'cohorts' of the aged, derived by comparing the mean income of men aged 60-69 in 1992 with men aged 70-79 in 2000, and so on. 
166 Peter Saunders and Lujun Sun

Table 10.2 Urban aged: mean incomes by age and gender in 1992 and 2000 (RMB per month and percentage)

\begin{tabular}{|c|c|c|c|c|c|c|c|c|}
\hline $\begin{array}{l}\text { Income } \\
\text { Source } \\
(2000)\end{array}$ & $\begin{array}{l}\text { Age: } \\
60-69 \\
R M B \\
\end{array}$ & $\%$ & $\begin{array}{l}70-79 \\
R M B \\
\end{array}$ & $\%$ & $\begin{array}{l}80+ \\
R M B\end{array}$ & $\%$ & $\begin{array}{l}\text { Total } \\
\text { RMB }\end{array}$ & $\%$ \\
\hline \multicolumn{9}{|l|}{2000} \\
\hline \multicolumn{9}{|l|}{ MALES: } \\
\hline Market income & 137.1 & 16.0 & 41.3 & 5.7 & 20.5 & 3.3 & 93.7 & 11.9 \\
\hline Pension income & 634.8 & 74.0 & 606.6 & 84.4 & 506.1 & 81.9 & 614.7 & 77.9 \\
\hline $\begin{array}{l}\text { Other Public } \\
\text { Transfers }\end{array}$ & 33.8 & 3.9 & 34.5 & 4.8 & 45.5 & 7.4 & 35.0 & 4.4 \\
\hline Private transfers & 25.0 & 2.9 & 23.8 & 3.3 & 34.4 & 5.6 & 25.3 & 3.2 \\
\hline Other income & 27.5 & 3.2 & 12.6 & 1.8 & 11.6 & 1.9 & 20.9 & 2.7 \\
\hline \multicolumn{9}{|l|}{ FEMALES: } \\
\hline Market income & 58.0 & 11.2 & 22.9 & 5.7 & 13.6 & 4.4 & 41.5 & 9.1 \\
\hline Pension income & 367.6 & 70.9 & 289.6 & 72.5 & 196.2 & 64.3 & 323.5 & 70.9 \\
\hline $\begin{array}{l}\text { Other Public } \\
\text { Transfers }\end{array}$ & 27.3 & 5.3 & 18.1 & 4.5 & 32.2 & 10.6 & 24.7 & 5.4 \\
\hline Private transfers & 43.4 & 8.4 & 57.8 & 14.5 & 62.2 & 20.4 & 50.2 & 11.0 \\
\hline Other income & 22.5 & 4.3 & 11.2 & 2.8 & 1.2 & 0.4 & 16.5 & 3.6 \\
\hline Total income & 518.9 & 100.0 & 399.6 & 100.0 & 305.2 & 100.0 & 456.4 & 100.0 \\
\hline \multicolumn{9}{|c|}{1992 (Mean incomes inflated to 2000 using the Consumer Price Index) } \\
\hline \multicolumn{9}{|l|}{ MALES: } \\
\hline Market income & 81.8 & 18.5 & 33.7 & 9.5 & 20.5 & 6.5 & 62.6 & 15.4 \\
\hline Pension income & 210.3 & 47.5 & 168.0 & 47.7 & 141.8 & 45.0 & 192.4 & 47.4 \\
\hline $\begin{array}{l}\text { Other Public } \\
\text { Transfers }\end{array}$ & 105.0 & 23.7 & 112.1 & 31.8 & 99.5 & 31.6 & 106.8 & 26.3 \\
\hline Private transfers & 27.1 & 6.1 & 27.1 & 7.7 & 44.0 & 14.0 & 28.2 & 6.9 \\
\hline Other income & 18.4 & 4.1 & 11.3 & 3.2 & 9.2 & 2.9 & 15.6 & 3.8 \\
\hline Total income & 442.4 & 100.0 & 351.9 & 100.0 & 315.1 & 100.0 & 405.5 & 100.0 \\
\hline \multicolumn{9}{|l|}{ FEMALES: } \\
\hline Market income & 12.1 & 8.9 & 22.8 & 5.3 & 5.8 & 3.4 & 17.7 & 7.6 \\
\hline Pension income & 54.5 & 39.9 & 102.5 & 30.7 & 26.5 & 15.4 & 83.7 & 36.1 \\
\hline $\begin{array}{l}\text { Other Public } \\
\text { Transfers }\end{array}$ & 43.3 & 31.7 & 81.4 & 31.0 & 40.6 & 23.5 & 72.0 & 31.0 \\
\hline Private transfers & 22.1 & 16.2 & 41.6 & 30.1 & 96.7 & 55.9 & 51.4 & 22.1 \\
\hline Other income & 4.5 & 3.3 & 8.5 & 2.9 & 3.2 & 1.8 & 7.1 & 3.1 \\
\hline Total income & 136.5 & 100.0 & 256.8 & 100.0 & 172.9 & 100.0 & 232.1 & 100.0 \\
\hline
\end{tabular}

Note

Market income includes income from earnings, self-employment and investments; transfer income includes income from pensions, and public and private transfers. 


\subsubsection{Expenditures on necessities}

The proportion of the total budget allocated to food and other basic items is often used as an indicator of the standard of living, following Engel's Law. The food ratio method still forms the basis of the official (government endorsed) US poverty line, although it has recently been proposed that the basket of necessities be extended to include housing and clothing (Citro and Michaels 1995).

Table 10.3 Urban aged: mean expenditures on basic necessities by age and gender in 1992 and 2000 (RMB per month and percentage)

\begin{tabular}{|c|c|c|c|c|c|c|c|c|}
\hline \multirow[t]{2}{*}{$\begin{array}{l}\text { Income } \\
\text { Source: }\end{array}$} & \multicolumn{6}{|l|}{ Age: } & \multicolumn{2}{|l|}{ Total } \\
\hline & $R M B$ & $\%$ & $R M B$ & $\%$ & $R M B$ & $\%$ & $R M B$ & $\%$ \\
\hline \multicolumn{9}{|l|}{2000} \\
\hline \multicolumn{9}{|l|}{ MALES: } \\
\hline Food & 201.1 & 73.2 & 188.4 & 75.7 & 161.4 & 76.0 & 193.5 & 74.3 \\
\hline Housing ${ }^{\text {(a) }}$ & 34.2 & 12.4 & 36.7 & 14.8 & 34.0 & 16.0 & 35.1 & 13.5 \\
\hline Clothing & 39.4 & 14.4 & 23.7 & 9.5 & 17.0 & 8.0 & 32.0 & 12.3 \\
\hline Total & 274.7 & 100.0 & 248.8 & 100.0 & 212.4 & 100.0 & 260.6 & 100.0 \\
\hline \multicolumn{9}{|l|}{ FEMALES: } \\
\hline Food & 179.9 & 82.8 & 166.1 & 75.4 & 172.7 & 81.5 & 174.5 & 75.6 \\
\hline Housing ${ }^{\text {(a) }}$ & 34.4 & 14.3 & 36.1 & 16.4 & 28.0 & 13.2 & 34.3 & 14.9 \\
\hline Clothing & 26.1 & 10.9 & 18.2 & 8.2 & 11.2 & 5.3 & 21.9 & 9.5 \\
\hline Total & 240.4 & 100.0 & 220.4 & 100.0 & 211.9 & 100.0 & 230.9 & 100.0 \\
\hline \multicolumn{9}{|c|}{1992 (Mean expenditures inflated to 2000 using the Consumer Price Index) } \\
\hline \multicolumn{9}{|c|}{ MALES: } \\
\hline Food & 185.8 & 76.5 & 164.4 & 81.4 & 152.9 & 84.3 & 177.0 & 78.3 \\
\hline Housing (a) & 21.8 & 9.0 & 19.2 & 9.5 & 15.0 & 8.3 & 20.7 & 9.2 \\
\hline Clothing & 35.2 & 14.5 & 18.4 & 9.1 & 13.4 & 7.4 & 28.4 & 12.6 \\
\hline Total & 242.8 & 100.0 & 202.0 & 100.0 & 181.3 & 100.0 & 226.1 & 100.0 \\
\hline \multicolumn{9}{|l|}{ FEMALES: } \\
\hline Food & 157.2 & 78.1 & 141.1 & 83.0 & 123.4 & 87.2 & 149.7 & 80.0 \\
\hline Housing (a) & 18.6 & 9.2 & 14.5 & 8.5 & 10.3 & 7.3 & 16.7 & 8.9 \\
\hline Clothing & 25.6 & 12.7 & 14.5 & 8.5 & 7.7 & 5.4 & 20.7 & 11.1 \\
\hline Total & 201.4 & 100.0 & 170.1 & 100.0 & 141.4 & 100.0 & 187.1 & 100.0 \\
\hline
\end{tabular}

Note

(a) Housing includes expenditure on utilities (water and electricity) and maintenance. 


\section{Peter Saunders and Lujun Sun}

This broader definition of necessities has been used to estimate a set of Low Income Cut-Offs by Statistics Canada (Wolfson and Evans 1989) - the closest that country has come to developing an official poverty line. With these developments in mind, Table 10.3 shows how expenditure on basic necessities food, housing and clothing - changed among the aged in China between 1992 and 2000. As before, the 1992 expenditures have been inflated up to 2000 in line with movements in the consumer prices (see note 4).

Both aged men and women devoted around three quarters of their basic budgets to food in 2000 . This represents a slight decline over the figure of around 80 per cent in 1992, indicating that living standards have risen over the period $^{5}$. Housing represents a small, though rising, proportion of spending on necessities, reflecting the widespread provision of low-cost government housing to the aged. The food ratio is higher for women then men and tends to increase with age, suggesting that living standards within the urban aged population follow a similar pattern to that implied by the mean incomes shown in Table 10.2. However, the pattern of necessary spending shows less fluctuation across age and gender categories, suggesting that the variations in subsistence poverty are less than those for total income (or total expenditure).

The high average food budget ratios highlight the low living standards of the aged in urban China at the turn of the century. It is instructive to compare them with the normative budget standard estimates derived for Australian households living in Sydney in 1997 by Saunders et al. (1998). The Australian standards indicate that spending on basic necessities in the areas included in Table 10.3 required by the aged to attain a low-cost standard of living (assuming they own their home outright) is equal to $\$ 105$ a week (single person) or $\$ 155$ (aged couple). Of these amounts, the proportion of necessary spending devoted to food is equal to 35.6 per cent (single) and 49.0 per cent (couple) - the higher ratio for couples reflecting the relative lack of economies of scale in food consumption. These comparisons highlight the huge differences that still exist between the living standards of the aged in the two countries.

\subsubsection{Subjective wellbeing}

Having examined two objective measures of economic status, Table 10.4 presents information on two subjective indicators of wellbeing and how they changed between 1992 and 2000. The two indicators (and the survey questions from which they are derived) are:

Resource Adequacy: In 2000, based on responses to the following question: According to your own assessment, how is your economic condition this year? Response categories: More than enough; Just enough; Rather difficult; Very difficult. In 1992, based on the following question: Do you feel your monthly income is enough? Enough, with money left; Just enough; No difficulty; Some difficulty; Much difficulty. 
Table 10.4 Changes in subjective well-being among the urban and rural aged, 1992 to 2000

\begin{tabular}{|c|c|c|c|c|c|}
\hline \multirow{2}{*}{ Indicator } & \multirow{2}{*}{ Definition } & \multicolumn{4}{|c|}{ Age: } \\
\hline & & $60-69$ & $70-79$ & $80+$ & Total \\
\hline \multicolumn{6}{|l|}{ URBAN MALES: } \\
\hline Resource Adequacy, 1992 & $\%$ 'Much difficulty' & 2.5 & 4.0 & 5.3 & 3.2 \\
\hline Resource Adequacy, 2000 & $\%$ 'Very difficult' & 2.5 & 2.4 & 5.4 & 2.7 \\
\hline Economic Security, 1992 & $\%$ 'Unsatisfied' & 5.5 & 5.5 & 6.3 & 5.6 \\
\hline Economic Security, 2000 & $\begin{array}{l}\% \text { 'Not economically } \\
\text { secure' }\end{array}$ & 16.6 & 17.4 & 18.4 & 16.9 \\
\hline \multicolumn{6}{|l|}{ URBAN FEMALES: } \\
\hline Resource Adequacy, 1992 & $\%$ 'Much difficulty' & 4.6 & 9.0 & 14.5 & 6.7 \\
\hline Resource Adequacy, 2000 & $\%$ 'Very difficult' & 4.1 & 7.0 & 9.8 & 5.6 \\
\hline Economic Security, 1992 & \% 'Unsatisfied' & 6.4 & 7.2 & 9.5 & 6.9 \\
\hline Economic Security, 2000 & $\begin{array}{l}\% \text { 'Not economically } \\
\text { secure' }\end{array}$ & 27.9 & 34.5 & 38.1 & 31.1 \\
\hline \multicolumn{6}{|l|}{ RURAL MALES: } \\
\hline Resource Adequacy, 1992 & $\%$ 'Much difficulty' & 8.8 & 14.2 & 14.1 & 10.9 \\
\hline Resource Adequacy, 2000 & $\%$ 'Very difficult' & 7.8 & 8.6 & 10.1 & 8.2 \\
\hline Economic Security, 1992 & $\%$ 'Unsatisfied' & 11.9 & 14.0 & 12.8 & 12.6 \\
\hline Economic Security, 2000 & $\begin{array}{l}\% \text { 'Not economically } \\
\text { secure' }\end{array}$ & 45.4 & 45.2 & 45.2 & 45.4 \\
\hline \multicolumn{6}{|l|}{ RURAL FEMALES: } \\
\hline Resource Adequacy, 1992 & $\%$ 'Much difficulty' & 11.6 & 13.2 & 13.2 & 12.3 \\
\hline Resource Adequacy, 2000 & $\%$ 'Very difficult' & 7.9 & 9.9 & 10.4 & 9.0 \\
\hline Economic Security, 1992 & $\%$ 'Unsatisfied' & 12.5 & 12.6 & 10.6 & 12.4 \\
\hline Economic Security, 2000 & $\begin{array}{l}\% \text { 'Not economically } \\
\text { secure' }\end{array}$ & 43.5 & 43.1 & 43.5 & 43.4 \\
\hline
\end{tabular}

Economic Security: In 2000, the question was: Do you think you are economically secure now? Yes; No. In 1992, the question asked was: Are you satisfied with your current economic condition? Response categories: Satisfied; Unsatisfied; Unclear.

The responses to these questions indicate that there are clear signs of progress in relation to perceptions of resource adequacy, although only of a modest degree - particularly in urban areas. There is also a narrowing of the urban/rural gap in perceived adequacy over the period, particularly for 


\section{Peter Saunders and Lujun Sun}

females. However, these modest gains in subjective adequacy must bebalanced against the substantial increases in the percentages that report feeling unsatisfied or insecure about their overall economic situation. The extent of the increase in the percentages reporting dissatisfaction or economic insecurity - well over threefold in the case of urban males and rural males and females, and in excess of fourfold in the case of urban females - suggests that China's growing national income and material prosperity has come at a price in terms of the perceived economic security of its aged population. This may in part be explained by the reality that aged incomes have not kept pace with general income growth, reinforced by the possibility that the aged are more likely to resist economic change (and thus to be less appreciative of its benefits) than younger members of the population. ${ }^{6}$

\subsection{Changes in attitude and informal support}

Community attitudes are important in the overall social support system in two respects. First, attitudes help to determine the relative roles of different components of the system, including the balance between formal (public) and informal (private) provisions. Bu they also reflect existing arrangements in ways that can constrain the scope for new initiatives. To bring about change, it is thus necessary to understand the nature of existing attitudes in order to devise reform strategies that are not counter to what prevailing community attitudes expect. This does not mean that attitudes are a binding constraint, but rather that they can affect the kinds of reforms that will win public support or at least the time frame within which new policies can attract community endorsement.

We begin by examining the pattern of attitudes among the aged in 2000 in relation to alternative forms of provision for support in old age. Respondents were asked to rank their first and second preferences among four alternative forms of preparation for old -age, and the responses are summarized in Table 10.5, which shows the first ranked option. The most preferred form of preparation for old age among both men and women is to spend money on one's children when they are young and rely on them to reciprocate that support later, when it is needed. Private saving is the next preferred option, followed by participation in a social insurance scheme. There is virtually no support for purchasing commercial insurance at least among the aged, for whom this is really no longer a viable option. Similar patterns pervade all age groups and are more pronounced among the older cohorts. Women tend to have stronger views than men, with almost half of all women favouring reliance on children, compared with just over a third of men.

Overall, there is a clear preference for family-based types of support, whether this takes the form of inter-generational transfers or individuals providing for themselves by saving (possibly through a combination of both options). Support for social insurance is less than that for these family mechanisms, but there is very little support for relying on the commercial sector to provide a reliable 
Table 10.5 Preferred forms of preparation for old age for young people, 2000 (percentages)

\begin{tabular}{|c|c|c|c|c|}
\hline Gender & $\begin{array}{l}\text { Age: } \\
60-69\end{array}$ & $70-79$ & $80+$ & Total \\
\hline \multicolumn{5}{|c|}{ Participating in a social insurance program: } \\
\hline Male & 25.9 & 23.0 & 21.3 & 24.7 \\
\hline Female & 18.6 & 15.6 & 10.6 & 16.8 \\
\hline \multicolumn{5}{|c|}{ Purchasing commercial insurance: } \\
\hline Male & 2.1 & 0.9 & 3.5 & 1.8 \\
\hline Female & 1.6 & 1.5 & 3.0 & 1.7 \\
\hline \multicolumn{5}{|c|}{ Spending all money on children and depending on them when getting old } \\
\hline Male & 35.6 & 38.6 & 45.7 & 37.2 \\
\hline Female & 47.4 & 53.7 & 64.5 & 50.9 \\
\hline \multicolumn{5}{|c|}{ Saving money for old age: } \\
\hline Male & 34.8 & 34.9 & 26.7 & 34.3 \\
\hline Female & 30.2 & 26.6 & 17.8 & 27.8 \\
\hline
\end{tabular}

source of support in old age. Self-provision or family support both rank above collective insurance options, with market-based solutions attracting minimal levels of support.

Clearly the aged in China show little support for the general direction of reform, although this is not unexpected since the reforms are aimed primarily at younger cohorts. But as noted earlier, the key point is that those in these younger age cohorts may react to the reforms in ways that run counter to the aspirations of the older cohorts.

Is there any evidence that the attitudes of the aged to the social support system have changed as the reform agenda has unfolded over the 1990s? Our ability to answer this question is constrained by the nature of the questions asked in the two CRCA surveys, although it is possible to explore two aspects of this issue. The first relates to whether or not the aged regard their children as filial or not - an issue that forms the basis of a question asked in both surveys. The responses these questions produced are summarized in Table 10.6.?

The results show that the vast majority of the aged believe that their children are filial, with the extent of belief among females slightly higher than among males, although the gender differences are quite small. There is, however, a decline of around 10 percentage points between 1992 and 2000 in the proportion of both males and females of a given age who believe that their children are filial. A similar decline is apparent among 'cohorts' of the aged, based for example on comparisons of those aged 60-69 in 1992 with those aged 70-79 in 
2000 , and so on. This is a marked change in attitudes in a relatively short period, all the more so given the widespread belief at the beginning of the 1990s that children are filial. This shift probably reflects the transitions that China is experiencing, and if it continues it is likely to have important consequences for the future structure of aged support arrangements.

Table 10.6 Percentage who think that their children are filial, 1992 and 2000

\begin{tabular}{|c|c|c|c|c|}
\hline Living arrangement: & $\begin{array}{l}\text { Age: } \\
60-69 \\
\end{array}$ & $70-79$ & $80+$ & Total \\
\hline \multicolumn{5}{|l|}{1992} \\
\hline \multicolumn{5}{|l|}{$M A L E:$} \\
\hline Living alone or with spouse & 85.3 & 81.2 & 71.3 & 82.8 \\
\hline Living with relatives & 87.1 & 86.8 & 88.0 & 87.1 \\
\hline Living with unrelated people & 50.0 & 50.0 & 100.0 & 60.0 \\
\hline Total & 86.4 & 84.2 & 80.1 & 85.3 \\
\hline \multicolumn{5}{|l|}{ FEMALE: } \\
\hline Living alone or with spouse & 83.9 & 81.7 & 76.1 & 82.7 \\
\hline Living with relatives & 88.8 & 87.4 & 89.2 & 88.4 \\
\hline Living with unrelated people & 100.0 & 75.0 & - & 71.4 \\
\hline Total & 86.9 & 84.9 & 85.1 & 86.2 \\
\hline \multicolumn{5}{|l|}{2000} \\
\hline \multicolumn{5}{|l|}{$M A L E$ : } \\
\hline Living alone or with spouse & 75.5 & 76.4 & 71.1 & 75.7 \\
\hline Living with relatives & 76.4 & 75.8 & 74.4 & 76.1 \\
\hline Living with unrelated people & 80.0 & 75.0 & 100.0 & 81.8 \\
\hline Total & 76.1 & 76.1 & 73.4 & 75.9 \\
\hline \multicolumn{5}{|l|}{ FEMALE: } \\
\hline Living alone or with spouse & 76.5 & 72.5 & 75.3 & 75.1 \\
\hline Living with relatives & 76.5 & 77.5 & 83.3 & 77.6 \\
\hline Living with unrelated people & 84.6 & 75.0 & 85.7 & 79.3 \\
\hline Total & 76.6 & 75.6 & 81.3 & 76.7 \\
\hline
\end{tabular}


Table 10.7 The incidence and amount of children's financial support for aged parents in urban and rural areas, 1992 and 2000 (percentages) $)^{(a)}$

\begin{tabular}{|c|c|c|c|c|c|}
\hline Characteristics & $\begin{array}{l}\text { Age: } \\
60-69\end{array}$ & $70-79$ & $80+$ & Total & $\begin{array}{l}\text { Average } \\
\text { monthly } \\
\text { support } \\
(\text { RMB2000) }\end{array}$ \\
\hline \multicolumn{6}{|c|}{ Children providing financial support to their aged parents: } \\
\hline \multicolumn{6}{|l|}{$U R B A N$} \\
\hline Males, 1992 & 30.0 & 39.1 & 47.9 & 34.0 & 75.0 \\
\hline Males, 2000 & 28.0 & 36.5 & 44.3 & 32.4 & 35.8 \\
\hline Females, 1992 & 46.2 & 64.3 & 80.5 & 54.3 & 91.0 \\
\hline Females, 2000 & 43.6 & 52.5 & 60.8 & 48.4 & 60.5 \\
\hline \multicolumn{6}{|l|}{$R U R A L$} \\
\hline Males, 1992 & 65.2 & 75.8 & 84.2 & 69.6 & 63.5 \\
\hline Males, 2000 & 60.1 & 68.9 & 78.7 & 64.3 & 37.7 \\
\hline Females, 1992 & 81.8 & 87.1 & 88.3 & 84.1 & 61.5 \\
\hline Females, 2000 & 68.8 & 70.2 & 70.0 & 69.4 & 38.9 \\
\hline \multicolumn{6}{|c|}{ Aged providing financial support to their children: } \\
\hline \multicolumn{6}{|c|}{$U R B A N$} \\
\hline Males, 1992 & 44.0 & 30.5 & 16.8 & 38.0 & 114.9 \\
\hline Males, 2000 & 67.5 & 62.9 & 47.8 & 64.3 & 190.7 \\
\hline Females, 1992 & 34.4 & 17.6 & 9.7 & 27.4 & 87.6 \\
\hline Females, 2000 & 64.3 & 47.8 & 34.8 & 55.7 & 124.8 \\
\hline \multicolumn{6}{|l|}{$R U R A L$} \\
\hline Males, 1992 & 19.5 & 11.2 & 11.5 & 16.2 & 41.2 \\
\hline Males, 2000 & 41.7 & 32.3 & 19.1 & 37.0 & 39.6 \\
\hline Females, 1992 & 15.8 & 9.0 & 9.8 & 12.9 & 35.2 \\
\hline Females, 2000 & 35.8 & 22.0 & 18.3 & 28.5 & 20.8 \\
\hline
\end{tabular}

Note

(a) Children include grandchildren.

But is the change in attitudes to family support implied by the results in Table 10.6 also reflected in any change in the degree of intra-family support actually provided? This issue is examined in Table 10.7, which shows the patterns of informal financial support that flow between the urban and rural aged and their children in each year. In order to keep the results manageable, only the aggregate results across all living arrangement categories are presented. ${ }^{8}$

Although they refer to financial (cash) transfers only, these results highlight the very important and ongoing role of private, inter-generational, intra-family support in China. Transfers between young and old operate in both directions and represent a significant element of the social support system - so significant that any analysis that omits them will be incomplete and likely to produce potentially misleading conclusions. In terms of the incidence of financial 


\section{Peter Saunders and Lujun Sun}

support, Table 10.7 indicates that there are marked differences by age, gender and location. As the aged get older, they become less likely to provide support to their children but increasingly more likely to receive it. Compared with the urban aged, the rural aged are much less likely to provide support to their children and far more likely to receive it - reflecting the urban/rural differential in living standards among the aged that was apparent from earlier results (Tables 10.2 and 10.3).

Within urban areas, aged males are less likely to receive support from children than females but are more likely to provide cash support to children this probably reflecting the higher average incomes of males. A similar pattern holds in rural areas, although the gender differences are less marked and the overall incidence of transfers from the aged to children is much lower. Finally, in terms of changes over time, the incidence of transfers from children to their parents has grown, while the incidence of transfers from the aged to their children declined. The same general pattern holds across all age and gender categories, and is apparent in both urban and rural areas.

In terms of the average monthly amounts transferred, Table 10.7 shows that (among those who make a positive transfer) the amount transferred from the aged to their children exceeds that from children to their aged parents in urban areas (particularly for males), whereas the opposite is the case in rural areas. On average, the value of transfers received by the urban aged from their children represents a small portion of male aged incomes, but represents a more significant contribution to female incomes (Table 10.2). In 2000, the size of the net monthly cash transfer from the aged to their children was around 155 RMB for urban males, $64 \mathrm{RMB}$ for urban females, virtually zero for rural males and minus $18 \mathrm{RMB}$ for rural females. These net figures clearly reflect the relative ability of different groups of the aged to provide support to their children, as reflected in the figures presented earlier. For the urban male aged, the size of the gross cash transfer to children is of a similar order of magnitude to average monthly expenditure on food, and well in excess of combined spending on housing and clothing (Table 10.3).

\subsection{Conclusions}

This chapter has examined a variety of different aspects of the living conditions of the aged in China and the attitudes held by the aged in an era of rapid economic and social change. The results presented have been derived from the 1992 and 2000 National Surveys of the Aged Population in China, which contain a wealth of data about the material circumstances of the aged, as well as their activities, values and attitudes. They show that although there have been obvious and substantial improvements in living conditions and economic prosperity, there are still marked age, gender and location differences in the economic circumstances of the aged. There is also evidence that while their objective economic circumstances have improved, the proportion of the aged who are concerned about their future economic security increased over the 1990s. The results also demonstrate that the family still plays a major role in 
supporting its aged members, but that they too provide extensive financial support for their children.

Although much of the debate over the response to China's rapidly ageing population has understandably focused on the need to reform the pension system, the results presented here indicate that this discussion needs to pay greater attention to the role of another major institution in Chinese society: the family. Unless this is done, there is a danger that pension reform will fail to adequately address the needs of the population, both young and old. While pensions policy has focused almost exclusively on the nature and role of the formal pension system as described in Section 10.2, such analysis also needs to take account of the role and impact of the largely hidden informal social support system if it is to become more relevant to the lives of the Chinese population and less concerned with the budgetary challenges facing government.

Together, the results in the latter part of the chapter (specifically in Tables $10.5,10.6$ and 10.7) shed light on the importance of China's informal system of support for the aged and the strongly held values and attitudes that underlie it. It is clear that the majority of the current generations of the aged still regard the family as the principal means of support in old age, followed by private saving. Social insurance is seen as a factor, but almost no one among the aged sees a role for private (commercial) insurance. More than three quarters of the aged also believe that their children are filial, although the percentage is declining. So too is the percentage who report receiving financial assistance from their children, and the amount provided is also falling. But the results also show that informal intra-family support for the aged remains important in China - for men and women, younger and older groups among the aged, and among both urban and rural aged. The institutional reform agenda in China needs to recognize and respond to these realities.

\section{Notes}

* This chapter is part of a broader project on The Role and Impact of the Social Support System on the Well-Being of the Elderly in China that is financed by the Australian Research Council under Discovery Project Grant DP0209592. The authors acknowledge the advice and assistance provided by their colleagues on the broader project Xiaoyuan Shang (at SPRC) and Zhang Kaiti, Guo Ping and Chen Gang (at CRCA). The usual caveats apply.

1 Throughout this chapter, results are presented disaggregated by age and gender and, in some instances, living arrangements. In some cases, this results in small cell sizes, particularly among the $80+$ age group.

2 The provinces/cities included in both the 1992 and 2000 surveys are: Beijing, Tianjin, Shanghai, Heilongjiang, Shanxi, Jiangsu, Zhejiang, Hubei and Sichuan.

3 The estimates in Table 10.2 refer to those provinces that were included in both surveys.

4 The Consumer Price Index was equal to 253.4 in 1992 and 476.6 in 2000, so all mean incomes (and expenditures - see below) in 1992 have been inflated by $476.6 / 253.4=1.881$ to obtain (approximate) purchasing power parity with year 2000 incomes.

5 The ratio of food expenditure to total expenditure has declined even further, indicating a larger increase in living standards.

6 The results in Table 10.4 may also be a statistical artefact, reflecting the changed wording of the survey questions - particularly the shift from three response categories to the 'satisfaction' question in 1992 to only two in 2000 . Although a number of respondents selected the 'unclear' category in 1992 (16.7 per cent of the urban sample and 19.6 per cent of the rural sample), there 


\section{Peter Saunders and Lujun Sun}

is no way of knowing how these people would have responded if this option had not been available. Even if half of these respondents had chosen the 'Unsatisfactory' response had it been available, the 2000 figures would still have been above those for 1992 .

7 The results in Table 10.6 are based upon only those provinces that were included in the survey in both years.

8 The disaggregated results add relatively little to the aggregate patterns described. 


\title{
11 Globalization and occupational health and safety regulation in China
}

\author{
Chris Nyland, Russell Smyth and Cherrie Jiuhua \\ Zhu
}

\subsection{Introduction}

Establishing and sustaining a sophisticated social protection regime is an important and necessary part of the process of globalization. This proposition has gained widespread appreciation as a result of the social instability generated by the financial crises that have afflicted Mexico, Southeast Asia, Russia and Argentina since 1995. As a consequence of these crises, together with the failure of big bang reforms in Central and Eastern Europe, even the International Monetary Fund (IMF) concedes that globalization strategies of nations need to include social protection measures that can insure populations against the volatility that characterizes global markets (IMF 2001). The term 'social protection' here refers to 'policies and programs designed to reduce poverty and vulnerability by promoting efficient labour markets, diminishing people's exposure to risks, and enhancing their capacity to protect themselves against hazards and interruption/loss of income' (ADB 2002a).

The fact that there has emerged a heightened appreciation of the positive contribution that social protection can make to the capacity of nations to globalize is a significant development. The evidence generated by advocates of this perspective is providing an important counterweight to the literature that holds that globalization constitutes a serious threat to the viability of the welfare state (Tanzi 2002). However, when the two literatures are considered simultaneously, what becomes apparent is that there exists a risk that globalization may be undermining its own social foundations. In other words, the opening of economies may be self-retarding because it tends to generate incompatible levels of competition, output, and income disparity. What is less appreciated, however, is the danger that globalization may undermine its own long-term viability. It could do this, for example, by raising the level of global competition to a point where governments believe that they cannot sustain the social protection pillars that are needed to preserve the dynamism of the globalization process.

As observers have become aware of this danger they have started to explore the character of the social protection regimes (both those extant and those being constructed) in countries that appear to be globalizing successfully (Gu 2001a, Song and Chu 1997, Smyth 2000a). In this chapter we extend this exploration 
through focusing on the occupational health and safety (OHS) regime currently being established in China. We focus on OHS in China for three reasons. First, it is one aspect of China's social insurance (shehui baoxian) package that has been largely under-researched. This is in spite of the fact that the World Health Organisation (WHO) has warned that globalization has a double-edged effect on OHS. While globalization has tended to improve this aspect of working life, in many instances there is a danger that it is inducing governments to dilute the legal, institutional and cultural bulwarks that protect workers' health.

A second reason for focusing on OHS reform in China is that in recent times there has been a succession of mining disasters highlighted in the Chinese and international media, which have put OHS issues in China in the spotlight (see for example Pan 2002; Schauble 2002a, 2002b, 2002c). In September 2000, Muzhong coal mine (the fourth largest coal mine south of the Yangtze River) exploded, killing 161 workers. This was the largest coal mining accident in China since 1949 (Lam 2000: 3). In June 2002 a gas explosion in the Chengzihe coal mine in Heilongiiang resulted in 115 deaths. In the same month a gold mine explosion in Shanxi killed 46 miners and a coal mine explosion in Jilin resulted in 39 deaths (Schauble 2002a). A third reason for this study is that there are a series of major reforms addressing OHS issues in China, which are very recent. On the inspectorate side there have been two major national laws passed in the last few years dealing with prevention of occupational diseases (October 2001) and with occupational safety (June 2002). On the insurance side a set of new regulations came into force in January 2004.

The concurrence of the emphasis on OHS and the tendency to reduce such protections due to globalization enables us to explore how the reform of an important area of social protection is being managed in a country that is actively seeking to expand its presence in the global economy. In considering this development, we examine how China is handling the contradiction inherent in the fact that the new regulations are meant to curtail the threat to the health and safety of workers generated by the processes of marketization and globalization, and at the same time to assist China to extend the marketization and globalization of its economy. The remainder of the chapter is set out as follows. First, we outline the concerns that have been expressed in the literature regarding the link between globalization and OHS, and how the WHO has responded to these concerns. We then proceed to examine the competing tensions underpinning OHS and workplace and insurance reforms due to increasing marketization and globalization in China. Finally, in the conclusion we speculate about the extent to which the government has been effective in managing these tensions and the implications for effective social protection in China.

\subsection{Globalization, the World Health Organisation and occupational health and safety}

The link between globalization and workers' health and safety has become an issue of concern for OHS scholars and practitioners because many observers 
have become convinced that open market policies have the capacity to both enhance and undermine the health of populations. Cornea (2001: 834), for example, has argued that while the removal of trade and financial barriers has improved the level of health enjoyed by the populations of some nations, it has produced stagnating health indicators in a great many others. Informed observers in both the developed and developing world have endorsed the notion that globalization is having this mixed or Janus-faced impact (Holkeri 2001). The only authors of note who have failed to acknowledge this trend are market fundamentalists such as Dollar (2001). He simply insists that as open market policies are a powerful force for raising the incomes of poor countries, and increased income has been shown to be associated with improved health, we can be confident that globalization is having a positive effect on health. This cavalier perspective has not been endorsed by the WHO, which accepts that at the very least it must be conceded that globalization has induced both increased health benefits and health risks. Consequently, they have advised that it is vital that appropriate domestic and global regulations and strategies be developed and enforced that are capable of promoting the benefits of globalization while containing the risks.

The concerns expressed by the WHO regarding the link between globalization and health have also been manifest in the OHS literature. For instance, Loewenson (2001) has warned that globalization has both positive and negative OHS dimensions. He advises that 'to reduce the adverse effects of global trade reforms on occupational health, stronger social protection measures must be built into production and trade activities, including improved recognition, prevention, and management of work related ill-health' (Loewenson 2001: 863). London and Kisting (2002) have echoed these concerns and in so doing note that market openness has increased the relative significance of the informal sector. They warn that this is a matter of concern because workers' health in this sector is notoriously difficult to regulate and consequently is characterized by very high levels of workplace injury and disease. In emphasizing this point, London and Kisting (2002) also warn that the trend for nations to make privatization of public services a central aspect of a broader globalization strategy is also a matter of great concern. The reason is that a shortage of well-trained public officials has been shown to contribute to the failure of health and related services to control the occupational disease burden.

As the WHO has come to accept that globalization has both positive and negative OHS dimensions, it has joined with the International Labour Organisation (ILO) in the building of a campaign targeted to alert nations to the need to incorporate health and safety into their globalization strategies. In 2001 it played a prominent role in an international conference in Helsinki on 'Work in the Global Village'. The conference was opened by Harri Holkeri, the President of the $55^{\text {th }}$ General Assembly of the United Nations, who warned that globalization poses a threat to the quality of workers' lives and working conditions in the developed states and even more so in the developing and transition countries. In so doing he observed: 
180 Chris Nyland, Russell Smyth and Cherrie Jiuhua Zhu

Governments need more co-operation and partnerships with regional and international organizations, but also with civil society actors to alleviate poverty and harmonize minimum labour standards and safety for workers. The private sector and investors should include into their social code support for a safe and healthy work environment. Nationally, legal framework, policies, service delivery, and access to education are means to ensure the realisation of human rights. Internationally, the rights-based approach to development needs a particular focus on occupational health and safety of the poor. (Holkeri 2001: 45)

Goldstein et al. (2001) from the WHO stress that there is an acute need to alert globalizing nations to the importance of OHS. They observe that while the global burden of occupational disease and injury is on a par with the burden from malaria, occupational health programmes receive only a tiny fraction of the resources devoted to combating malaria. Goldstein et al. (2001) add that the need to be aware of OHS costs has become even greater with the more flexible work practices that tend to be associated with globalization. These authors make the further point that there is a great fear that the stress of global competition may lead employers to view the prevention of occupational injuries and protection of workers' health not as an integral part of quality management, but as a barrier to trade (Goldstein et al. 2001: 56).

\subsection{OHS and occupational insurance reforms in China}

The increasing pace of China's economic reforms and associated challenges to its state-owned sector, coupled with China's accession to the WTO, has made social welfare reform a pressing issue. In this section we critically examine how the Chinese government has managed the tension in the OHS area between fostering the framework needed to underpin the dynamism required to compete in global markets and creating an institutional mechanism to protect workers from the negative side effects of globalization. The information is based primarily on a series of interviews with key stakeholders conducted by the authors in Beijing in July 2002. Interviews were conducted with senior officials from the State Administration of Work Safety, the Ministry of Labour and Social Security and the ILO in Beijing. These interviews with policymakers were supplemented with a case study of a large multinational enterprise in Beijing, also conducted in July 2002, to ascertain how the OHS and work injury insurance reforms operated in practice.

The Chinese government is clearly aware of the need to create a more competitive environment to enable it to compete in global markets and also of the importance of sharing the costs of social protection as part of this process. As market transition gathered speed, there was a widespread recognition that the danwei-based (organization-based) welfare system was inadequate. It impeded the development of the service sector, hindered labour mobility and represented a huge financial burden on the state sector. As a result there has been a shift 
towards an institutional welfare state (Titmuss 1974), which is underpinned by welfare pluralism ( $\mathrm{Gu}$ 2001a: 109). This is part of a general trend towards reforming the 'iron rice bowl' and 'iron armchair' of lifetime employment for cadres. Drawing on interviews in 10 large and medium-sized state-owned enterprises (SOEs) between 1995 and 2000, Morris et al. (2001: 711) report that some managers in SOEs were being employed on three-year contracts, which could be terminated for failure to meet performance criteria. At the beginning of 2003, the Chinese government announced that employment contracts would be introduced for all SOE workers over the course of the next three years. ${ }^{1}$

China is an active collaborating member of the WTO's Global Strategy, and indeed the first network meeting was held in Shanghai in 1992. The Chinese government insists that this involvement is part of China's 'trend toward globalization'. It argues that globalization will help improve the OHS regime and that accession to the WTO will enable China to meet the economic costs associated with OHS as well as making it necessary for stakeholders to show they are meeting the new international obligations they have assumed. This was a point stressed in January 2002 by Yang Fu, director of the Technological Improvement and Equipment Department under the State Administration of Work Safety Supervision, when announcing the national government's intention of establishing a 'standardized workplace-safety system' in Chinese enterprises (Fu 2002). To further this process, in April 2002 the government introduced a new national standard for occupational health and safety management systems the GB/T 28001-2001 national standard. At the time it was issued, Shi Baoquan, deputy administrator of the State Administration for Standardization, declared that this standard 'will be effective in making enterprises aware of health and safety and maintaining their awareness' (Li 2001).

The association between marketization, globalization and industrial health, though, is a 'controversial topic' (Wong 2000) in China. The problem is that the new institutional welfare state with its emphasis on mutual responsibilities is still at an embryonic stage. Thus it is questionable whether or not it is able to protect workers from the vicissitudes of globalization. Our interviews suggest that in the OHS area the main problem rests with monitoring and enforcement of standards. In particular, the marketization and globalization drive has created a large floating migrant workforce in the eastern seaboard of China. Consistent with London and Kisting's (2002) views about the effect of globalization on enforcement of labour standards in the informal sector, protecting the OHS rights of migrant workers has been particularly troublesome. The State Administration of Work Safety has been running an educational campaign to increase awareness of OHS issues. However, in line with Goldstein et al.'s (2001) concerns cited above, workers' health and prevention of occupational injuries in China are still not seen by employers as an integral part of quality management, but as a factor driving up the cost of business. 


\subsection{Some figures on OHS in China}

Numerous observers have argued that globalization and marketization have intensified the problem of occupational accidents in China. The empirical evidence supports this conclusion. Table 11.1 presents official statistics on the number of work-related fatalities and work-related major injuries in China between 1979 and 1998. The figures on work-related injuries and work-related fatalities prior to 1993 are for SOEs and collective-owned enterprises (COEs) at the county level and above. From 1993, the figures also include collective township and village enterprises (CTVEs). Since 1994 the official statistics on work-related injuries show a downward trend, but casual observation suggests that this is not believable.

Table 11.1 Work-related fatalities and injuries in China

\begin{tabular}{llllll}
\hline Year & $\begin{array}{l}\text { Number of } \\
\text { Employees }\end{array}$ & $\begin{array}{l}\text { Work-Related } \\
\text { Fatalities }\end{array}$ & $\begin{array}{l}\text { Work-Related } \\
\text { Fatalities per } \\
\text { 1000 } \\
\text { Employees }\end{array}$ & $\begin{array}{l}\text { Work- } \\
\text { Related } \\
\text { Major } \\
\text { Injuries }\end{array}$ & $\begin{array}{l}\text { Work-Related Major } \\
\text { Injuries per 1000 } \\
\text { Employees }\end{array}$ \\
\hline 1979 & 6992.7 & 13054 & 0.187 & 29618 & 0.423 \\
1980 & 7349.7 & 11582 & 0.157 & 27472 & 0.374 \\
1981 & 7506.5 & 10393 & 0.138 & 24315 & 0.324 \\
1982 & 7769.7 & 9867 & 0.117 & 23264 & 0.299 \\
1983 & 7934.4 & 8994 & 0.113 & 19778 & 0.249 \\
1984 & 8034.7 & 9088 & 0.113 & 18650 & 0.232 \\
1985 & 8379.5 & 9847 & 0.118 & 18216 & 0.217 \\
1986 & 8656.2 & 8982 & 0.104 & 16484 & 0.190 \\
1987 & 8964.0 & 8658 & 0.097 & 14954 & 0.167 \\
1988 & 8964.0 & 8908 & 0.099 & 12404 & 0.138 \\
1989 & 9167.1 & 8657 & 0.094 & 10788 & 0.118 \\
1990 & 9321.2 & 7759 & 0.083 & 10105 & 0.108 \\
1991 & 9516.3 & 7855 & 0.083 & 9117 & 0.096 \\
1992 & 9251.2 & 7994 & 0.086 & 8327 & 0.090 \\
1993 & 9000.0 & 19820 & 0.220 & 9901 & 0.110 \\
1994 & 8672.0 & 20315 & 0.234 & 9103 & 0.150 \\
1995 & 8537.9 & 20005 & 0.234 & 8197 & 0.096 \\
1996 & 8273.1 & 19457 & 0.235 & 7274 & 0.088 \\
1997 & 7879.0 & 17558 & 0.223 & 6197 & 0.079 \\
1998 & 5597.1 & 14660 & 0.262 & 5623 & 0.101 \\
\hline
\end{tabular}

Source: China's Work Safety Yearbook 1979-1999: 606

Notes

Figures prior to 1993 are for state-owned enterprises and collective-owned enterprises at the county level and above. From 1993 the figures include township and village enterprises. 
While the official statistics on fatalities might be reasonably accurate, they almost certainly understate the prevalence of serious accidents. This is widely accepted among observers (see ILO 1998: 10, Lam 2000: 3). According to Table 11.1 , since 1993 the number of work-related fatalities has been greater than the number of work-related major injuries. The ILO official that we interviewed pointed out that normally the number of work-related fatalities and major injuries should be like a pyramid: in other words, far fewer people die than are injured at work. However, the statistics in China look like an upside-down pyramid, with more fatalities being reported than injuries. This indicates that workplace injuries may only be reported when fatalities occur, while workrelated injuries could be substantially under-reported. ${ }^{2}$

The statistics in Table 11.1 are based on reports of accidents to the State Administration of Work Safety, which enforces the OHS laws and administers penalties to firms which are in violation of those laws. It is well known in China that firms under-report accidents to the State Administration of Work Safety in order to minimize applicable penalties. Officials in the State Administration of Work Safety openly acknowledge this.. The Ministry of Labour and Social Security, which administers work-related injury insurance, has more realistic figures because these are based on actual claims by workers. However, as discussed in more detail later in the chapter, the problem is that the coverage of the insurance scheme is limited to 40 per cent of urban enterprises, so reasonably reliable figures are therefore only available for a relatively small subset of total enterprises. ${ }^{4}$

Traffic accidents are the most common form of work accident (74.96 per cent) in China followed by mining accidents (8.85 per cent) (He 2002). The official number of fatalities in mining accidents in China has hovered around 10,000 per annum since 1990 (ZLTN, various). According to the ILO, fatalities due to mining accidents in China constitute 60 per cent of the fatalities due to mining accidents worldwide. ${ }^{5}$ Table 11.2 compares the number of mining deaths per million tonnes of coal produced in China with equivalent figures for the United States, India, Russia, South Africa and Poland. The figure for China is 11 times higher than for Russia and 182 times higher than for the United States.

Table 11.2 Fatalities in coal mines

\begin{tabular}{llll}
\hline & $\begin{array}{l}\text { Coal Produced } \\
\text { (million tonnes) }\end{array}$ & Fatalities & $\begin{array}{l}\text { Deaths per Million } \\
\text { Tonnes of Coal } \\
\text { Produced }\end{array}$ \\
\hline China & 1396 & 10015 & 7.29 \\
United States & 975 & 38 & 0.04 \\
India & 294 & 137 & 0.47 \\
Russia & 264 & 172 & 0.66 \\
South Africa & 213 & 48 & 0.23 \\
Poland & 203 & 45 & 0.23 \\
\hline
\end{tabular}

Source: China State Coal Industry Bureau, reported in Schauble (2002b)

Note

Figures are for 1996. 
While poor OHS standards exist in large state-owned coal mines (Lam 2000), the worst offenders are usually small-scale coal mines which are owned privately or by CTVEs (He 2002). The number of work-related fatalities in CTVEs is higher than in SOEs. A survey by the Ministry of Labour in the mid1990s found that the number of work-related fatalities in CTVEs was four to five times higher than in SOEs (cited in ILO 1998: 10).

Coal mines are the major cause of pneumoconiosis (a lung disease associated with dust) in China. Silicosis and coal miners' pneumoconiosis account for about 85 per cent of all recorded cases of pneumoconiosis in China (Zou et al. 1997, He 2002). The cumulative number of recorded cases of pneumoconiosis in China between 1949 and 1996 was 524,759, of which 134,678 proved fatal (Zou et al. 1997: 1). The annual number of official new cases of pneumoconiosis reported each year is in the range of 8,000 to 9,000, which understates the extent of the problem because of under-reporting by small mines (ILO 1998, Liang et al. 1998). Lam (2000: 4) suggests that a more accurate figure would be 15,000 to 20,000 new cases of pneumoconiosis each year; and even this is likely to be a conservative estimate.

In 2000, the number of verified cases of pneumoconiosis was 42,500 (He 2002: 2), but a further 520,000 workers who have been exposed to dust are suspected of having silicosis (Liang et al. 1998: 2). Physical examinations of workers in 30,000 CTVEs across 15 provinces in 1990 found that 4.4 per cent of the workers had one of seven occupational diseases: silicosis, coal worker's pneumoconiosis, asbestosis, chronic lead poisoning, benzene analogs poisoning, chronic chromium poisoning or noise-induced hearing loss. A further 11 per cent had illnesses suspected of being, though not proven to be, due to occupational exposures (Su et al. 2000). The ILO (1998: 11) states: 'Official figures of occupational diseases in CTVEs should ... be regarded as the tip of the iceberg.' The reason for this is that as most CTVEs have only been established since the 1980s, the period of workers' exposure to hazards has not yet been long enough to develop into diseases such as pneumoconiosis, but this could occur in the future.

\subsection{Recent reforms in the regulation of OHS}

Prior to 1998 OHS was under the jurisdiction of the Ministry of Labour and Social Security (which was called Ministry of Labour at that time). In 1998 responsibility for occupational health was transferred to the Ministry of Health and responsibility for safety was transferred to the State Economic and Trade Commission (SETC). In 2001 the SETC established the State Administration of Work Safety and State Bureau of Coal Mine Safety to oversee occupational safety in all enterprises under its supervision. Thus there are now three types of workplace inspections. These are safety (which is under the jurisdiction of the State Administration of Work Safety), health (which is under the jurisdiction of the Ministry of Health) and general labour inspections. The latter cover issues such as child labour, working hours and general working conditions (which are 
still the responsibility of the Ministry of Labour and Social Security). There are two problems with having multiple agencies carry out inspections. One problem is that there is a lack of coordination and cooperation between the agencies. The other is that having to receive different agencies for related inspections increases the costs to the firm.

There are a myriad of laws and technical standards on OHS, which have been issued in a piecemeal fashion. These include the Regulation of Work Safety for Mining Industries (1982); Rules on Occupational Health Services for CTVEs (1987) and the Labour Law (1994) (for a more complete list see Liang et al. 1998: 4). The Labour Law is too broad. As an ILO Report puts it, 'it stipulates that management is responsible for ensuring workers' health and safety', but it 'does not specify the concrete measures needed for enterprise action' (ILO 1995). Since the Labour Law was enacted, two national laws dealing with prevention of occupational diseases (passed in October 2001) and occupational safety (passed in June 2002) have come into force.

\subsubsection{Monitoring and enforcement is problematic}

While the government has put the legal framework in place to provide protection for workers' health and safety, in order to be an effective safeguard in the face of increasing levels of marketization, the laws must be enforced. As it stands, monitoring and enforcement are the major challenges facing OHS legislation. Under the occupational safety laws passed in June 2002, if a firm does not implement the safety laws, the State Administration of Work Safety under the direction of the SETC can prosecute the firm and, if need be, close it down. There are, however, a number of difficulties hindering the effective implementation of the occupational safety laws.

The first problem is that there are large numbers of small and medium enterprises outside the reach of the State Administration of Work Safety given the small number of inspectors relative to the number of enterprises. In the mid1990 s there were about 12,000 OHS inspectors at the provincial, prefectural and county levels (ILO 1998). As a result, the ILO (1998: 17) notes: 'Even in counties which assign priority to TVE inspection, collectively and individually owned small TVEs are outside the scope of inspection.' These firms often just pay lip service to safety requirements or ignore them altogether. This is illustrated by the situation in the Fuqiang mine in Jilin Province. According to one media report: 'Safety laws pinned to the walls are "just for show". ... While someone is detailed to monitor the gas levels, even when they reach high levels the miners are not allowed to leave until they have finished their shift' (Schauble 2002a).

The State Administration of Work Safety's task in enforcing the safety regulations in CTVEs is also made more difficult because local governments provide protection to their CTVEs. ${ }^{6}$ One reason for this is that fiscal decentralization in China has starved local governments of revenue and created a linkage of interests between local governments and enterprises (Wong 1992). In this fiscal environment, CTVEs have been a major source of local government 


\section{Chris Nyland, Russell Smyth and Cherrie Jiuhua Zhu}

revenue (Deng and Smyth 2000). Thus if CTVEs are forced to implement higher safety standards this will increase their costs, diminish their profits and reduce revenue flows to local government. Local government obstruction has also been exacerbated by a State Council Resolution (Document No. 302, issued in 2001). This Resolution puts obligations for major work accidents on local officials, which creates incentives for local officials to cover up work accidents. ${ }^{7}$

The State Administration of Work Safety has established branches at province and county levels to oversee safety inspections consistent with the new laws, but in order to fill these new posts it has had to recruit a number of new staff, who lack experience and possibly commitment. ${ }^{8}$ In the interviews we conducted, representatives from the State Administration of Work Safety admitted that, given resource constraints, sometimes investigations of breaches are only in response to media pressure. The representatives of the State Administration of Work Safety gave the concrete example of the gold mine explosion in Shanxi in June 2002, which had occurred in the month prior to the interviews. Initially the owner had reported that there were two deaths, and had attempted to conceal the bodies of other miners who had died in the explosion; but the media reported 37 deaths prompting the State Administration of Work Safety to investigate. ${ }^{9}$

A further problem is that even where the State Administration of Work Safety inspectors possess the commitment, enterprises often ignore the compliance order. Lam (2000: 3) states: 'Local media often report that after the labour department investigated workplaces where serious accidents happen, some factories simply ignore the Notes for Compliance.' An example is the Dingsheng coal mine in Heilongjiang Province, where an explosion in July 2002 killed 44 people. The mine had failed a safety inspection earlier that year, had its licence suspended and had been ordered to stop operations just a week prior to the explosion (Schauble 2002a). There are various reasons why enterprises might ignore compliance orders. In some cases, particularly in small enterprises, the problem is either that there is a lack of awareness of relevant laws or that enterprises do not have the resources to make the relevant changes. ${ }^{10}$ An inevitable consequence of globalization is that small CTVEs are under increasing pressure to keep costs down, and maintaining OHS standards is often regarded as a barrier to trade. Increasing marketization has also generated opportunities for corruption. Lam (2000) suggests that corruption and abuse of authority are important factors in firms' avoidance of compliance. He states: 'Some [firms]'are powerful enough to bypass inspections and safety requirements even where the hazards are obvious' (Lam 2000: 3).

\subsubsection{Protection of migrant workers is problematic}

Marketization and more flexible labour markets have created opportunities for migrant labour from rural areas to flood into China's cities and wealthier coastal regions in search of work and higher incomes. The influx of foreign direct investment as the Chinese economy has opened up has facilitated this process through creating job opportunities. The floating population of migrant workers 
in China has been estimated to be between 120 million and 150 million people (Pan 2002). Many of these work in CTVEs or joint ventures in the coastal provinces in special economic zones (SEZs) such as Xiamen (Fujian) and Shenzhen, Zhuhai and Shantou (Guangdong). While migrant workers provide cheap labour that fuels the globalization process, the existence of large pools of migrant labour makes it easier for firms to avoid their obligations under the OHS legislation. This is because migrants are often either unaware of the legislation or willing to work without the correct occupational protection.

This impedes the government's efforts to create the social protection mechanism appropriate to curtailing the adverse effects of globalization, because it takes OHS issues outside the legal framework that has been put in place to protect workers' rights. While they are illegal, 'life or death contracts' (where workers agree to work without OHS safeguards) are prevalent in small CTVEs and private firms ${ }^{11}$ Migrants often receive lower wages than local workers, but are willing to accept these conditions because they can still earn much more than in their communities of origin (Hare 1999, Knight et al. 1999). Where workers are injured, under-the-table payments where the injury is not even recorded are common. ${ }^{12}$ In these circumstances, it is normal for factories to give injured workers a lump-sum compensation payment, which is usually less than the legal minimum, and to force the workers to leave (Lam 2000: 4).

The ILO (1998: 14) estimates that there are 30 million migrant workers in China working in substandard conditions. These workers typically work long hours. A survey of migrant workers (75 per cent of whom were female) in the Pearl River Delta in the mid-1990s found that most were working 12 hours a day (cited in ILO 1998: 15). There are several reports of cases in Shenzhen and other SEZs where workers have not been given proper instructions on how to operate machines, resulting in disablement and loss of limbs (Chan 2001, Ash 2002, Lam 2000).

Migrant workers also constitute a disproportionate number of those working in hazardous industries such as coal mining and construction. In the major coalmining province of Shanxi, it is estimated that 50 per cent of coal mine workers are migrants from other provinces such as Anhui and Sichuan (ILO 1998: 14). It has also been reported in the Hong Kong media that owners of private companies that employ migrant workers frequently change their employees before they start to show the symptoms of occupational diseases. ${ }^{13}$ One of the major reasons that protecting migrant workers is problematic is that their social status is lower relative to local workers and their occupational status is transient (Li and Han 1994, Lee 1995, ILO 1998, Knight et al. 1999). Migrant workers also have fairly low awareness of trade union activities. The survey of migrant workers in the Pearl River Delta that was mentioned above found that only 14.6 per cent were aware of trade unions in their factories (cited in ILO 1998: 14).

\subsubsection{The role of employer groups and trade unions}

The trade unions were consulted in drafting the new OHS laws through input from the All-China Federation of Trade Unions (ACFTU), and the laws set out 


\section{Chris Nyland, Russell Smyth and Cherrie Jiuhua Zhu}

obligations of the trade unions. Where workers feel too intimidated to report accidents or unsafe work practices, it is considered the role of the trade unions to report these things. In all joint ventures with more than 25 workers the workforce is entitled to join a trade union. In other countries, trade unions have often been at the forefront of protecting workers' rights in the face of greater globalization. As a reflection of the shift towards embracing the concept of an institutional welfare state, the Chinese government proffers a similar role for trade unions in firms with foreign involvement in China. The view was expressed in the interviews that the government encourages a strong union presence in joint ventures and foreign-owned firms to act as its watchdog on health and safety issues. ${ }^{14}$

The ACFTU is a top-down establishment, however, and this curtails the role that it can play in effective enforcement (Lam 2000: 2). One of the main difficulties has traditionally been a lack of membership. Of the 2.4 million foreign-funded enterprises, private enterprises and CTVEs, according to the ACFTU's figures only 12 per cent have trade unions (Lam 2000: 2). Most of these are in large CTVEs. For example, in Nanjing about 70 per cent of large CTVEs have trade unions (ILO 1998: 19). This means that in most small CTVEs and private firms, often where workers are most vulnerable to poor OHS standards, there is no trade union involvement. These surveys were conducted prior to an amendment to the Trade Union Law (2001) which granted trade unions the legal rights to formally monitor workplaces, and precipitated a campaign to increase the level of unionization. The expanded role for trade unions is outlined in the ACFTU's Blue Paper published in January 2003. The Blue Paper touches on the protection of workers' rights in nine areas including OHS (ACFTU 2003). This paper was released after we had completed the fieldwork for this project, however, and, at the time of writing, it is still too early to gauge its effect.

While the functions of trade unions have been fairly limited in OHS, employer groups were not even part of the process of drafting the new OHS laws. ${ }^{15}$ As long as the SETC still has an important policy role it is difficult for strong employer associations to evolve. Thus employers have little or no input into the formulation of labour policies ${ }^{16}$ The OHS activities of those employer groups which do exist, such as the Chinese Enterprise Directors' Association, are limited (ILO 1998: 19). Thus when the occupational safety laws were passed in June 2002, it was taken as given that employers would need to meet their commitments according to the legislation. ${ }^{17}$

It might be argued that the SETC represented employer groups in drafting the laws, but with their myriad of policy responsibilities (Johnston 2002), the SETC is not an effective voice for employers in any real sense. This is problematic because it is difficult for the State Administration of Work Safety to enforce the safety laws effectively when one of the key stakeholders is more or less excluded at the law formulation stage. Excluding employers makes it difficult for the government to tell them in a top-down fashion that they should be treating OHS as an integral part of quality management, rather than as a barrier to integrating into global markets, when they were not involved in the consultation process. 


\subsubsection{Policies to increase awareness}

The State Administration of Work Safety is focusing on increasing awareness of safety laws as the key to reducing workplace accidents. Thus complementing efforts to increase the number of workplace inspections, it is attempting to create a culture of improved work safety through a range of measures designed to increase awareness of safety issues. First, all senior managers have been given a copy of the safety law passed in June 2002, and senior managers in all enterprises are required to take training seminars on OHS. Second, the State Administration of Work Safety has sponsored a series of seminars given by prominent legal academics and practitioners designed to explain the operation of the laws to enterprises. Third, the central government has introduced 'safety month' to publicize particular issues in occupational safety. ${ }^{18}$ The problem, however, is that in practice most of the training programmes are restricted to large firms and do not extend to small CTVEs or private firms where little information on OHS is available. Moreover, most of the training programmes focus on legal requirements of the law rather than giving practical guidance on how to improve safety levels (ILO 1998: 18-19).

\subsection{Workplace accident and injury insurance reforms}

\subsubsection{Recent legislative developments}

Prior to the 1980s, industrial injury insurance was governed by the Regulations on Labour Insurance in China (1951), which provided for enterprise-based insurance. The problems with the Regulations on Labour Insurance included low coverage, lack of legal enforcement and lack of scientific criteria for the assessment of injuries and compensation (Liu 2000: 14-15). The main problem with the danwei-based insurance approach, however, was that the level of treatment an injured worker received was tied to a firm's performance. Thus workers in poorly performing firms received less compensation than they deserved (Liu 2000, Tang 2001). In the late 1980s, under the pressures of greater marketization and faced with mounting losses in the state-owned sector, these arrangements were no longer sustainable. This method of funding workplace accident compensation started to change as part of broader reforms to the workplace-based welfare system (see for example Leung 1994, Croll 1999, Gu 2001a, Liu 2000).

Under the Interim Regulations on Occupational Injury and Disease Insurance passed in 1996 a social pooling fund was established and administered by the Social Insurance Administration in the Ministry of Labour and Social Security. Under the Interim Regulations, enterprises contributed a percentage of their payroll to the fund and the benefits were paid out of the fund to workers who suffered work-related injuries. Contributions to the fund were transferable between enterprises. In 2001 the Ministry of Labour and Social Security started 
190 Chris Nyland, Russell Smyth and Cherrie Jiuhua Zhu

revising the Interim Regulations; new regulations were passed in 2003 and came into operation at the start of 2004.

\subsubsection{The definition of a work-related injury}

Once an accident has been reported, the State Administration of Work Safety identifies the cause of the accident and determines whether or not it was a workrelated accident. Following this, the Social Insurance Administration in the Ministry of Labour and Social Security determines the appropriate level of compensation based on a table of maims. An important issue in this process relates to how the State Administration of Work Safety decides what is a workrelated accident. This is particularly true in problematic grey areas such as injuries incurred in travelling to and from work, which are covered under the definition of work-related accidents. The ILO (2002: 77) is critical of the ability of the State Administration of Work Safety to make the right decision in cases such as this given the lack of experience of the staff and the absence of internal guidelines.

The Interim Regulations defined a work-related accident broadly to include work-related stress. The term 'work-related stress' is vague, making it relatively easy for workers to claim compensation as job-related. The revised regulations make it much clearer which injuries/diseases can be claimed as work-related, in an attempt to narrow the scope..$^{19}$ The coverage of the insurance scheme has also been reduced by the introduction of related legislation since the Interim Regulations were enacted. For instance, medical insurance schemes now cover many diseases, which were originally covered by the Interim Regulations.

\subsubsection{Rates of contribution and social pooling}

Enterprise contributions to the social pooling fund consist of a fixed (or industry) rate and a floating (or firm) rate. The fixed rate, which is broken into four categories depending on the occupational risk in the industry, varies between 0.3 per cent and 3 per cent of the payroll, with the average being 1 per cent (Liu 2000: 156). It is reviewed every five years. Prior to 1998 industrial injury insurance was industry based. Thus all workers in the same industry had the same coverage. However, from 1998 industrial injury insurance has been geographically based, and rates differ between geographic regions. The central government draws up the general guidelines and it is left to municipalities to implement them. One problem with this approach is that people working in the same industry in different geographic regions have different levels of coverage. ${ }^{20}$ There is also considerable variation in the manner in which fixed rates are determined at the local level. In some provinces, such as Liaoning, fixed rates are determined at the pool level. In other provinces, such as Guangdong, the same rates are used for all of the province. For example, in Guangdong there are three rates $(0.5$ per cent, 1 per cent and 1.5 per cent). The advantage of setting the fixed rates at the pool level, as in Liaoning, is that this can better handle the 
industries that are prevalent in each pool and differences in industries across the province (ILO 2002).

The floating rate, which varies from year to year depending on accidents in the previous year, is between 5 per cent and 40 per cent of the fixed rate (Liu 2000: 157). The Social Insurance Administration Bureau in the Ministry of Labour and Social Security maintains a record of funds contributed and funds expended for each enterprise. This is used to judge the firm's performance record and assess whether the floating rate should be increased or decreased. ${ }^{21}$ Under one novel approach to insurance reform, which is being trialled in some areas, but at this stage has not been earmarked for the national regulations, initially the floating rate is reduced to zero if the firm has no accidents over a certain period of time. Once the floating rate is reduced to zero, if the firm continues to be accident-free, it is permitted to contribute below the fixed rate. ${ }^{22}$

Social pooling is restricted to the town/county level. A percentage of contributions from each pool is transferred to the city and to the province, which is used to cross-subsidize pools which are in an unfavourable financial position (ILO 2002: 78). In practice, cross-subsidization occurs between richer and poorer areas correlated with the level of economic development. ${ }^{23}$ The main problem is that the level of pooling is too low and, as a result, some provinces have many small pools that are difficult to manage. The ILO (2002) notes: 'A major advantage of large pools is their financial stability. The experience is more predictable and the fund can protect against annual fluctuations with a relatively modest reserve.' For instance, Guangdong has more than 100 pools, with many small pools that are forced to protect themselves against fluctuations through reinsurance. While some developed countries such as Canada also have small pools, this increases the cost of administration to the fund (ILO 2002: 78).

\subsubsection{Limitations of coverage}

The 1996 Interim Regulations only applied to urban enterprises, and only 40 per cent of urban enterprises participated in the insurance scheme. ${ }^{24}$ At the end of 2001, 43.5 million workers out of 107.9 million employees in the urban area were covered by the industrial injury insurance scheme (White Paper 2002: 4). In contrast, in 2000104.5 million employees in urban areas were covered by pension insurance and 103.3 million employees in urban areas were covered by unemployment insurance (ZLSHBZN 2001: 697-702). Given that China's workforce in the secondary and tertiary industries is approximately 365 million, this means that only about 12 per cent of them were covered by industrial injury insurance, while 28.6 per cent and 28.3 per cent were covered by pension and unemployment insurance respectively. ${ }^{25}$ In Guangdong, where industrial injury insurance coverage is relatively high, more people were covered by industrial injury insurance than pension insurance; in other provinces, however, coverage was patchy. ${ }^{26}$

One of the problems with the Interim Regulations was that they only said that 'enterprises' should join the scheme. The term 'enterprises' is ambiguous and it was not clear whether this extends to CTVEs. ${ }^{27}$ Thus most of those workers who 


\section{Chris Nyland, Russell Smyth and Cherrie Jiuhua Zhu}

were covered were in the state-owned sector, ${ }^{28}$ while workers in private enterprises, which have flourished in the marketization process, largely lay outside the reach of the scheme. This is significant because the private sector share of the gross value of industrial output jumped from almost zero at the start of the reforms to over 35 per cent in 2000 , and the private sector employs over 100 million people (ZTN 2001 and Xiao 2001). The revised regulations clarify the meaning of 'enterprises' and give the provinces the power to extend coverage to workers in rural areas (ILO 2002: 76).

One of the main reasons for the low level of coverage is that under the regulations there is no compulsion for the enterprise to contribute to the fund. In contrast, under the safety laws, if a firm does not meet the required safety standards it can be prosecuted and closed down. Thus under the safety laws the level of legal obligation is higher. ${ }^{29}$ Under the insurance regulations the risk is placed on the firm. If the enterprise chooses not to join the scheme it is liable for meeting the costs of industrial injuries to its workers (White Paper 2002: 4). The amount which firms that have not joined the scheme are expected to pay to their injured workers is specified in the regulations and, in theory, the firm cannot avoid these obligations through declaring bankruptcy. ${ }^{30}$

If a firm that has not joined the insurance scheme is unable to pay its injured workers it can be prosecuted, but this is up to the central government. The government can either provide compensation to the injured workers itself or close down the firm and sell off its assets. ${ }^{31}$ The latter might be a viable response if the reform process was taking place in a vacuum; but the reform process in China is not taking place in a socio-political vacuum. The interaction between institutional and non-institutional factors (such as the ideological setting) affects the speed of reforms and helps shape the political course of the reforms (Thelen and Steinmo 1992, Gu 1997). One of the main implications of marketization is that there has been an escalation in the number of laid off (xiagang) workers from the state-owned sector. According to official figures there were 26 million workers laid off between 1998 and 2002 (Armitage 2003). This is a major social problem, and it is being exacerbated by the process of globalization as China's SOEs are faced with increased levels of competition following its accession to the WTO.

The problem is that China's embryonic social security system does not have the capability to cope with further redundancies, particularly in the worst affected areas in the 'iron rust belt' of China's industrial north-east. ${ }^{32}$ In the interviews we conducted, the senior officials in the Work Injury Insurance Division of the Ministry of Labour and Social Security admitted when pressed that closing down firms was not really an option given the need for political and social stability. ${ }^{33}$ Hence, the political realities of the reform process mean that in the end the government takes responsibility for the injured workers in firms that have not joined the scheme.

Within this process there is a very limited role for private insurers. The regulations encourage enterprises to take out supplemental private insurance in addition to the state-sponsored scheme. This was not clear in the Interim Regulations issued in 1996, but is made clearer in the Revised Regulations. Thus it is envisaged that supplemental private insurance should top up compensation 
under the state scheme. In better performing enterprises which can afford it, particularly foreign-owned firms and joint sino-foreign ventures, motivation for taking out supplemental private health insurance might be to create a better work environment to attract potential employees. However, in the interviews with the Work Injury Insurance Division we were told that 'very few' enterprises take out supplemental private insurance. ${ }^{34}$

\subsection{OHS and work accident insurance in a multinational enterprise}

\subsubsection{Background to the case study}

In order to examine how the OHS laws and workplace accident insurance scheme worked in practice, we conducted an in-depth case study in a subsidiary of a multinational electronics enterprise. The firm where we conducted the case study is located in the Beijing Tianzhu Airport Industrial Zone (hereafter 'the industrial zone') near Beijing Capital Airport. In July 2002 we conducted interviews with both representatives of the industrial zone and the human resources manager who is in charge of OHS issues in the enterprise. ${ }^{35}$

The central government offers firms that set up factories in the industrial zone tax-free status for their first two years and then half normal tax rates for the next three years of operation. Up to December 2001, there were 94 enterprises in the industrial zone with investments totalling \$US 1.22 billion. Of these, 70 per cent were multinational enterprises and 15 were Fortune 500 companies. Within the industrial zone there are five 'parks' catering for electronics, logistics, industrial materials, biotechnology and returned overseas Chinese startups. As of December 2001 there were 21 electronics companies in the industrial zone, including well-known multinational companies such as Ericsson, JVC, Motorola and Panasonic.

The firm where we conducted the case study was established in 1989 as a 50/50 joint venture, but in 1997 it became a wholly foreign-owned subsidiary. It produces predominantly for the domestic market in China, with annual sales of over 30 million RMB. In 1989 the firm initially had 20 employees, but by the time it became wholly foreign-owned this number had doubled and at the time of the interviews it had 130 employees. The male/female staff ratio in the enterprise is about one to one. The wage structure in the enterprise consists of a base amount and bonuses. The base wage at each level is transparent, but the bonuses are confidential.

\subsubsection{Insurance and safety issues in the industrial zone}

As discussed earlier, the national regulations on workplace accident insurance do not make it compulsory for enterprises to join the scheme. However, under the legislation establishing the industrial zone, all enterprises in the zone must join the state-sponsored workplace accident insurance scheme as a condition of setting up there. The industrial zone has an enterprise service department which 


\section{Chris Nyland, Russell Smyth and Cherrie Jiuhua Zhu}

is responsible for the implementation of safety laws in the zone. The enterprise service department performs a dual role with respect to safety. First, it is responsible for monitoring and enforcement. It carries out safety inspections on each enterprise in the industrial zone every quarter. There is also a joint inspection of the enterprise service department and State Administration of Work Safety, which occurs once a year during safety month. As part of its monitoring and enforcement role the enterprise service department also operates a hotline service where workers can phone in and voice safety concerns or report accidents in their workplace. Second, the enterprise service department performs an educational function. It runs regular seminars covering the nature and implementation of the safety laws. Attendance at the seminars is compulsory for the CEOs and other senior managers of enterprises in the zone.

\subsubsection{Insurance and safety issues in the electronics firm}

The enterprise participates in the state-sponsored workplace accident insurance scheme, but does not have supplementary private insurance. Before the government introduced the state insurance scheme, the enterprise had private insurance coverage, but it gave this up when it joined the state scheme. The firm provides safety orientation for all new recruits which outlines the firm's policy on safety and provides relevant training. During the interviews we focused on three questions: how are the laws implemented in practice? Do foreign firms bring a different culture on safety? Do OHS standards differ between ownership forms?

\subsubsection{How are the laws implemented in practice?}

The inspection process at the enterprise consists of three stages: self-inspections, quarterly inspections by the industrial zone, and annual inspections required by the central government. In the local council area in which the industrial zone is located, all safety inspections are carried out by a safety work committee, which is a lower tier of the State Administration of Work Safety. All employees of the enterprise are required to have an annual medical check-up, which is enforced by the Ministry of Health. The three kinds of annual workplace inspections health, labour and safety - required by the central government are performed at the same time each year. If the inspections find a problem the firm is issued with a directive (colloquially referred to as a 'red-head document') to fix it within a specified time, which is usually a week. If the firm fails the inspections it can be given a financial penalty or, in the case of blatant abuses, closed down.

\subsubsection{Do foreign firms bring a different culture on safety?}

When the joint venture was first established, all managers in the new joint venture did a training course in the multinational enterprise's home country. While the training course covered safety issues, it focused only on the technical aspects of safety. The parent company has not made a conscious attempt to 
implement safety standards from the home country in its Beijing subsidiary. However, management from the parent company has made recommendations from time to time on where safety could be improved. These have included suggestions such as the need for stronger lights for soldering and more visible safety notices. These recommendations have been implemented. Interestingly, all safety notices in the factory are in both Chinese and English. The safety notices in English are purely for the benefit of management from the parent company when they visit the plant. Other foreign companies have also had an influence on the firm in terms of safety issues. For example, the case enterprise also manufactures products for General Electric, which puts emphasis on work safety and the prevention of industrial accidents. The firm must maintain a good safety record in order to receive further contracts from General Electric.

\subsubsection{Do OHS standards differ between ownership forms?}

The human resources manager at the enterprise had worked for the firm when it was a joint venture, before it became a wholly foreign-owned subsidiary. $\mathrm{He}$ also had experience working in SOEs. In the interview we asked him whether the switch from joint venture to wholly foreign-owned subsidiary had had any effect on addressing safety issues in the firm. He was of the view that since the firm had become wholly foreign-owned there was less freedom to address OHS issues. In a joint venture or an SOE, it is much easier to get the funding to fix problems specified in a 'red-head document' issued by a government department, as Chinese managers seldom question or challenge the government's directives. However, once the firm became wholly foreign-owned he needed to provide more justification than a directive from a government department such as a local State Administration of Work Safety Bureau as to why changes to the working environment were needed. This is mainly for two reasons. First, a foreign company will generally not blindly follow the instruction given by a government department if it is not sufficiently explained. Second, in a foreign-owned company every dollar used has to be justified, rather than just spending money to satisfy the government's requirements.

\subsection{Conclusion}

In the first part of the chapter we argued that marketization and globalization have a dual effect on OHS. On the one hand, providing an effective social protection mechanism is a precondition for further marketization and opening up to the outside world. On the other hand, providing the institutional mechanisms to protect workers' occupational health and safety is an integral part of protecting workers from the negative aspects of globalization. In the second part of the chapter we examined how the Chinese government has managed this tension in the OHS area.

We have argued that the Chinese government recognizes the importance of providing an effective social protection mechanism as an essential part of building competitive enterprises. This is reflected in the shift from the mini- 
welfare state to the establishment of an institutional welfare state based on welfare pluralism where the individual, enterprise, state and society share the costs of providing the social safety net (Leung 1994, Gu 2001a). The opening up of markets to global competition has had an important role in necessitating the shift to an institutional welfare state. Since its recent accession to the WTO, China has been trying to 'get on track with the international community' (gen guoji jiegui), which indicates China's preparedness to have its economy and society further subjected to the discipline of global markets.

The real issue is whether the social protection mechanism which China has in place is able to protect workers from the vicissitudes of global competition. As one scholar from the Guangdong Academy of Social Science has noted, Chinese enterprises should not only get on track with international economic practices which have been made a priority, but also with the protection of workers' interests and rights. ${ }^{36}$ On this score, while the institutional and legal framework for protecting OHS standards exists, monitoring and enforcement is proving difficult. The process of globalization has contributed to making it hard to monitor and enforce OHS laws through creating an informal sector in the wealthier coastal cities where migrants from rural areas are willing to work in sub-standard conditions because the returns are greater than in their communities of origin. Under these circumstances there is an obvious role for trade unions to protect workers' rights and for employer groups to take the lead in promoting OHS standards as an important aspect of quality management, rather than as a barrier to trade. The problem, however, is that employers' groups do not have an effective voice in China and were not even involved in drafting the OHS laws, while the value of the ACFTU is hampered through lack of membership. Trade union membership is concentrated in large firms, while in most small private firms, where workers are particularly vulnerable to poor OHS standards, there is no trade union involvement.

This has more general implications for the success of the institutional welfare state. As globalization has increased competition in China, employers have been forced to contain their costs through reducing the protection offered to employees. The result is the potential for 'demoralization on the shop-floor' as workers are squeezed between the demise of the iron rice bowl system and the state's failure to provide a new social safety net (Lee 1999: 66). This has led to mass demonstrations, in particular in the Southwest and Northeast of China (Morris et al. 2001: 705-706). Since the economic reforms started in the late 1970s, the Chinese government has largely dropped the Mao-era rhetoric of the virtues of the working class and their right to lead industry and state. However, in protesting the demise of the iron rice bowl, the workers themselves continue to use the old formulations about being the leading class, which is proving uncomfortable for the Chinese state (Morris et al. 2001: 709). Given this, Frenkel and Kuruvilla (2002: 390) argue that the government needs to take preemptive action to effectively protect employees' rights so as 'to limit potential political instability and maintain working-class support'. Providing effective protection from the volatility of global markets would seem to be a precondition for such continuing working-class support. 
As has always been the case with market economies, the provision of effective OHS services invariably comes at a cost to employers, employees and the state; and trade-offs must be made. In making these decisions, vested interests will invariably influence what the respective stakeholders deem to be acceptable economic and health costs. A common response by those who would place the emphasis on the economic dimension is to insist that of course workers' health is important, but that this issue cannot be accorded a high priority until the society has reached a very high stage of development. This is a claim that is commonly advanced by China's non-state employers and by many officials, often with the rider that OHS only became an issue in the nations of the developed world once these nations had developed. This is a response that is morally and historically incorrect, for in the West workers' organizations and in many cases the state were able to become effective agents of OHS at a much earlier stage of development than currently characterizes much of China. Globalization has radically accelerated the extent to which China has been able to reap the gains from the marketization process that has been ongoing since the late 1970s. If the marketization process is to be extended and the benefits of this windfall fully realized, then globalization needs to be secured. One important way in which this can be achieved in China is by ensuring that workers perceive that they are benefiting from the process not only economically but also in terms of their health and security.

\section{Notes}

'Death knell of life-long tenure', China Daily, 7 January 2003.

Interview at the ILO office, Beijing, July 2002.

Interview with the Director of the State Administration of Work Safety, Beijing, July 2002.

Interview with the Deputy Chief, Division of Work Injury Insurance, Ministry of Labour and Social Security, Beijing, July 2002.

Interview at the ILO office, Beijing, July 2002.

Interview with the Director of the State Administration of Work Safety, Beijing, July 2002.

Interview at the ILO office, Beijing, July 2002.

Interview at the ILO office, Beijing, July 2002.

Interview with the Deputy Chief, Division of Work Injury Insurance, Ministry of Labour and Social Security, Beijing, July 2002.

10 Interview at the ILO office, Beijing, July 2002.

11 Interview at the ILO office, Beijing, July 2002.

12 Interview with the Director of the State Administration of Work Safety, Beijing, July 2002; interview at the ILO office, Beijing, July 2002.

13 Hong Kong Commercial Daily, 15 September 2002, p. B1.

14 Interview with the Deputy Director, Social Insurance Administration, Ministry of Labour and Social Security, Beijing, July 2002.

15 Interview with the Director of the State Administration of Work Safety, Beijing, July 2002.

16 Interview at the ILO Office, Beijing, July 2002.

17 Interview with the Director of the State Administration of Work Safety, July 2002.

18 Interview with the Director of the State Administration of Work Safety, July 2002.

19 Interview with the Deputy Chief, Division of Work Injury Insurance, Ministry of Labour and Social Security, Beijing, July 2002.

20 Interview with the Deputy Director, Social Insurance Administration, Ministry of Labour and Social Security, Beijing. July 2002. 
21 Interview with the Deputy Director, Social Insurance Administration, Ministry of Labour and Social Security, Beijing, July 2002.

22 Interview with the Deputy Director, Social Insurance Administration, Ministry of Labour and Social Security, Beijing, July 2002.

23 Interview with the Deputy Director, Social Insurance Administration, Ministry of Labour and Social Security, Beijing, July 2002.

24 Interview with the Deputy Chief, Division of Work Injury Insurance, Ministry of Labour and Social Security, Beijing, July 2002.

25 See <http://www.molss.gov.cn/tongji/gb/GB2001.htm>.

26 Interview with the Deputy Director, Social Insurance Administration, Ministry of Labour and Social Security, Beijing, July 2002.

27 Interview with the Deputy Director, Social Insurance Administration, Ministry of Labour and Social Security, Beijing, July 2002.

28 Xinhua News Agency, 'China to Expand Industrial Injury Insurance Coverage for Workers', 10 May 1999.

29 Interview with the Deputy Chief, Division of Work Injury Insurance, Ministry of Labour and Social Security, Beijing, July 2002.

30 Interview with the Director of the State Administration of Work Safety, July 2002.

31 Interview with the Deputy Chief, Division of Work Injury Insurance, Ministry of Labour and Social Security, Beijing, July 2002.

32 For a discussion of the socio-economic problems due to rising redundancies see $\mathrm{Gu}(1999)$ and Lee (2000).

33 Interview with the Deputy Chief, Division of Work Injury Insurance, Ministry of Labour and Social Security, Beijing, July 2002.

34 Interview with the Deputy Chief, Division of Work Injury Insurance, Ministry of Labour and Social Security, Beijing, July 2002.

35 The information presented in this section is based on interviews at the industrial zone and the enterprise as well as written material supplied at the time of the interview at the industrial zone.

36 Hong Kong Commercial Daily, 15 September 2002, p. B1. 
SECTION FOUR 



\title{
12 China's entry to the WTO
}

\author{
Effects of reducing tariff and non-tariff \\ barriers and endogenous productivity growth
}

\author{
Yinhua Mai
}

\subsection{Introduction}

The effects of China's entry to the World Trade Organisation (WTO) have been vigorously studied in recent years. A rich body of literature estimating the effects of China's accession commitments in tariff reductions using CGE models has emerged (for examples see Zhai and Li 2000, Li and Lejour 2001, Lejour 2001, Fan and Zheng 2001, Ianchovichina and Martin 2001, Li et al. 2001, François and Spinanger 2002, Mayes and Wang 2002, and Mai et al. 1998). In these analyses, the estimated benefits from reductions in tariff and non-tariff barriers are generally low. For example, the tariff reductions are estimated to elevate China's real GDP by only 0.8 per cent in Li and Lejour (2001), 0.081.66 per cent in Lejour (2001), 0.06-0.62 per cent in Fan and Zheng (2001), 2.2 per cent in Ianchovichina and Martin (2001), and about 1 per cent (in real Gross National Expenditure) in Mai et al. (1998). The absence of endogenous productivity growth has been listed in the literature as one possible reason for the generally low estimates (Ianchovichina and Martin 2001, and Mai et al. 1998). However, not much work on the effects of trade liberalization under an assumption of endogenous productivity growth has yet been published. This study is therefore devoted to comparing the effects of China's WTO tariff commitments with and without the assumption of endogenous productivity growth. The study shows that the percentage increase in real GDP due to the tariff reductions could be doubled when endogenous productivity growth is assumed. Furthermore, this study shows that the impact of the tariff reductions on employment in different regions in China can be quite different with and without the assumption of endogenous productivity growth.

Endogenous productivity growth occurs when local producers survive import competition by seeking input-saving technologies and production practices. A liberalizing industry has a good chance to experience endogenous productivity growth when it has existing economies of scale (especially in exporting) and when it resides in a country that lies far from technology frontiers. The latter factor enables it to import advanced technologies that are readily available in the rest of the world.

In this chapter the effects of China's commitments in reducing tariffs and tariff equivalents of non-tariff barriers are analysed using a Computable General 


\section{Yinhua Mai}

Equilibrium (CGE) model of China. In Section 12.2 I introduce the analytical framework, the PRCGEM model, and changes to the model made for this analysis. In Section 12.3 I present estimates of the effects of reducing tariff and non-tariff barriers with and without endogenous productivity growth. In Section 12.4 - $12.6 \mathrm{I}$ present the macroeconomic, industry and regional effects on different regions for China. Section 12.7 contains concluding comments.

\subsection{The modelling framework}

The analytical framework used in this analysis is an enhanced version of PRCGEM, a comparative static CGE model of China (see Zheng and Fan 1999 for details about PRCGEM). The core CGE structure of PRCGEM resembles that of the ORANI model (see Dixon et al, 1982 and Horridge 2001). The effects of policy changes on different regions in China can be simulated with a topdown regional extension.

In this analysis, PRCGEM is adapted to run in a recursive dynamic fashion. A system of equations and variables that captures shifts in technology and consumer tastes was added so as to develop a baseline of practical use (see Dixon and Rimmer 2002 for how to develop such a baseline). The effects of any policy changes are represented as deviations from the baseline.

In the baseline simulation, historical data and forecasts for macroeconomic indicators published by specialist forecasting agencies including the World Bank, Economist Intelligence Unit, China Bureau of Statistics, and Chinese Academy of Social Sciences are incorporated into the model. These indicators include growth in real GDP, consumption, investment, employment, exports and imports at the macroeconomic level, and output for aggregated sectors at the industry level (Table 12.1). The trend of changes in technology and consumer tastes estimated from historical Chinese data is also incorporated into the baseline.

Table 12.1 Baseline: history and forecasts of average annual growth 2000-2006, per cent

\begin{tabular}{ll}
\hline GDP & $2000-2006$ \\
Consumption & 7.6 \\
Investment & 6.0 \\
Exports & 10.3 \\
Imports & 10.4 \\
& 11.0 \\
Output of aggregated sectors & \\
$\quad$ Agriculture & \\
$\quad$ Mining & 3.0 \\
$\quad$ Manufacturing & 6.0 \\
$\quad$ Construction & 8.7 \\
Services & 10.4 \\
\hline
\end{tabular}

Source: Baseline simulation. 
The policy scenarios are simulated under long-run assumptions for factor markets. Labour is mobile between industries, but economy-wide labour supply is constrained by long-run population growth. Capital, on the other hand, is mobile between countries and industries within a country. Capital flows into and out of China in response to its rate of return on capital. Within China, capital flows into the industries that have higher rates of return.

To capture endogenously the effects of the trade-liberalization induced productivity improvements, extra data and equations are added into PRCGEM. The calculation is based on the Productivity Commission's time series estimates (Chand et al. 1998), taking into account the distance of a country from the technology frontier represented by the United States, and a country's revealed comparative advantage in a certain product (see Mai 2003 for more details).

Figure 12.1 shows the endogenous productivity growth induced by the reductions in tariffs (and tariff equivalents of non-tariff barriers) simulated in this study for the clothing and motor vehicles industries respectively. Although the Mmtor vehicles industry has a larger reduction in border protections, the induced productivity growth is much smaller for the Motor Vehicles industry than for the clothing industry. This is because China is a well established exporter in clothing. On the other hand, the motor vehicle industry in China serves mainly the domestic markets.

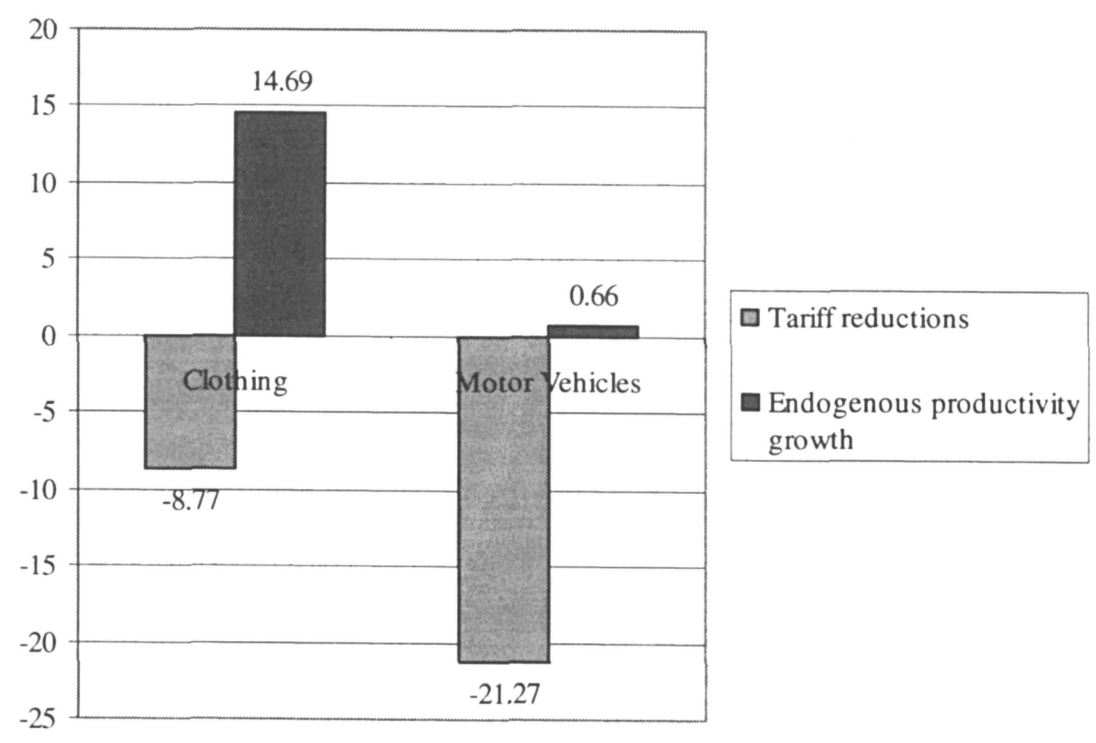

Figure 12.1 Tariff reductions and endogenous productivity growth 


\subsection{Effects of tariff reductions and endogenous productivity}

China's WTO commitments of reductions to tariffs and the tariff equivalents of non-tariff barriers are well summarized in Mayes and Wang (2002) and are simulated in this study for agricultural and manufactured products (see Appendix A, Table A.1, p. 208). I assume the reductions in tariffs and non-tariff barriers to be implemented over the five years 2002 to 2006 .

The tariff reductions are simulated under two scenarios:

Scenario 1: tariff reductions with endogenous productivity growth; and Scenario 2: tariff reductions without endogenous productivity growth.

The results for the two simulations are presented in Tables 12.2 to 12.5 .

\subsection{Macroeconomic effects}

Table 12.2 shows that, as a result of the tariff reductions, China's real GDP is likely to be 2 per cent higher than the baseline by 2006 , taking into account the endogenous productivity growth induced by the tariff reductions. Without the endogenous productivity growth, China's real GDP is likely to be 1 per cent higher than the baseline by 2006 (Table 12.2). China's gain in real GDP from the tariff reductions is much higher with the endogenous productivity growth than without it.

The tariff reductions lead to lower import prices. As investment goods are import-intensive, the prices of capital creation fall, leading to a higher rate of return on capital in China. The resulting increases in investment and capital lead to a higher real GDP under both scenarios.

Table 12.2 Macro effects of reducing tariff and non-tariff barriers; percentage deviation from baseline by 2006

\begin{tabular}{lcc}
\hline & $\begin{array}{l}\text { With endogenous } \\
\text { productivity improvement }\end{array}$ & $\begin{array}{l}\text { Without endogenous } \\
\text { productivity improvement }\end{array}$ \\
\hline GDP & 1.95 & 0.96 \\
Consumption & 1.95 & 0.96 \\
Investment & 2.31 & 1.98 \\
Exports & 8.94 & 6.31 \\
Imports & 10.47 & 8.86 \\
Real exchange rate & 1.13 & 1.66 \\
\hline
\end{tabular}

Source: Policy simulations.

Furthermore, under Scenario 1, the gain in real GDP also has endogenous productivity growth as a contributing factor (Table A.1 in Appendix A shows the endogenous productivity growth induced by the tariff reductions simulated). 
Under the circumstance of Scenario 1, primary factors are used more efficiently compared with the case of Scenario 2. China therefore gains more from the tariff reductions under Scenario 1, where removing protection prompts firms to improve their productivity.

The higher level of real GDP allowed Chinese consumers to enjoy a higher level of consumption. As a result of the higher levels of consumption and investment, China is importing at a higher level compared with the baseline (Tables 12.2 and 12.4). Another factor behind the higher imports is a substitution away from domestically produced goods and towards imports as post-duty import prices fall following the tariff reductions.

Table 12.2 shows that exports increase following the tariff reductions. This is due to a real depreciation. China's real exchange rate, defined as the ratio of CIF import price index (the pre-duty price) over the GDP price index, depreciates following the tariff reductions. This is because the tariff reductions lead to lower post-duty prices of imports that, in turn, lead to lower production costs and therefore a lower GDP price index.

\subsection{Industry results}

The effects of tariff reductions on individual industries are governed by a number of factors. The lower (post-duty) import prices following the tariff reductions lead to substitution away from domestically produced goods and towards imports. Industries that serve primarily domestic markets therefore suffer. On the other hand, the real depreciation benefits industries that supply to export markets. Furthermore, the endogenous productivity growth induced by tariff reductions helps industries that achieve those productivity improvements to become more competitive in both domestic and export markets.

Clothing is a typical industry that serves both export and domestic markets. It is, however, more export oriented compared with heavy manufacturing industries such as the motor vehicle industry. It has therefore gained significantly from real depreciation. Furthermore, because of the large tariff reductions on clothing and its existing economies of scale in exporting, the clothing industry is also a good candidate for achieving endogenous productivity improvements when faced with import competition. Its gains from the real depreciation and productivity improvements therefore offset its loss in domestic markets. Tables 12.3 and 12.4 show that the output and exports of the clothing industry rise significantly above the baseline as a result of the tariff reductions. The gains to the clothing industry in terms of output and exports are much higher when endogenous productivity growth is taken into account (Tables 12.3 and 12.4).

The motor vehicle industry, on the other hand, was almost entirely oriented towards domestic markets before China's accession to the WTO. Its loss in domestic markets is therefore great and is not offset by any gains in exports. While there are large reductions in tariffs on motor vehicles and parts, its lack of economies of scale in exporting prohibits the motor vehicle industry from achieving large productivity gains induced by the tariff reductions (see Table 
A.1 in Appendix A). The motor vehicle industry therefore stands out as the loser from the tariff reductions in terms of output and exports (Tables 12.3 and 12.4).

Table 12.3 Effects of reducing tariff and non-tariff barriers: sectoral output; percentage deviation from baseline by 2006

\begin{tabular}{lcc}
\hline & $\begin{array}{l}\text { With endogenous } \\
\text { productivity improvement }\end{array}$ & $\begin{array}{l}\text { Without endogenous } \\
\text { productivity improvement }\end{array}$ \\
\hline Agriculture & 0.38 & -0.44 \\
Mining & 0.92 & 0.65 \\
Manufacturing & 2.25 & 0.92 \\
Cotton textile & 7.19 & 2.23 \\
Clothing & 13.38 & 5.49 \\
Bricks and tiles & 2.07 & 1.49 \\
Iron and steel & 0.73 & 0.44 \\
Machinery NEC & 1.02 & 0.70 \\
Motor vehicles and parts & -9.68 & -9.94 \\
Electronic appliances & 6.00 & 4.38 \\
Construction & 2.32 & 1.97 \\
Services & 2.28 & 1.24 \\
\hline
\end{tabular}

Source: Policy simulations.

Table 12.4 Effects of reducing tariff and non-tariff barriers: exports and imports by commodity; percentage deviation from baseline by 2006

\begin{tabular}{lcccc}
\hline & $\begin{array}{l}\text { Exports } \\
\text { With } \\
\text { endogenous } \\
\text { productivity } \\
\text { improvement }\end{array}$ & $\begin{array}{l}\text { Without } \\
\text { endogenous } \\
\text { productivity } \\
\text { improvement }\end{array}$ & $\begin{array}{l}\text { Imports } \\
\text { With } \\
\text { productivity } \\
\text { improvement }\end{array}$ & $\begin{array}{l}\text { Without } \\
\text { endogenous } \\
\text { productivity } \\
\text { improvement }\end{array}$ \\
\hline Agriculture & -5.03 & -2.33 & 23.86 & 18.49 \\
Mining & -0.20 & 1.50 & 3.35 & 1.93 \\
Manufacturing & 9.67 & 6.61 & 11.45 & 9.90 \\
Cotton textile & 12.57 & 6.80 & 17.89 & 14.86 \\
Clothing & 18.44 & 8.15 & 15.36 & 16.31 \\
Bricks and tiles & 3.14 & 3.50 & 5.35 & 3.93 \\
Iron and steel & 2.54 & 3.05 & 7.41 & 6.26 \\
Machinery NEC & 3.34 & 3.75 & 11.75 & 10.45 \\
Motor vehicles and & -0.73 & -0.20 & 36.68 & 35.23 \\
parts & & & & \\
Electronic appliances & 13.26 & 11.99 & 19.36 & 17.73 \\
\hline
\end{tabular}

Source: Policy simulations. 


\subsection{Regional effects}

The PRCGEM model has a top-down regional extension that allows the calculation of the effects of any policy changes on different regions in China according to their shares in the national output for different industries. The effects of the reductions in tariffs and non-tariff barriers on different regions in China are presented in Table 12.5.

Table 12.5 Effects of reducing tariff and non-tariff barriers: gross output by region; percentage deviation from baseline by 2006

\begin{tabular}{|c|c|c|c|c|}
\hline & \multicolumn{2}{|c|}{$\begin{array}{l}\text { With endogenous productivity } \\
\text { improvement }\end{array}$} & \multicolumn{2}{|c|}{$\begin{array}{l}\text { Without endogenous } \\
\text { productivity improvement }\end{array}$} \\
\hline & Output & Employment & Output & Employment \\
\hline Liaoning & 1.56 & -0.12 & 0.76 & -0.06 \\
\hline Jilin & 0.81 & -0.44 & 0.02 & -0.56 \\
\hline Heilongjiang & 1.24 & -0.02 & 0.59 & -0.19 \\
\hline Beijing & 1.83 & -0.24 & 0.88 & 0.05 \\
\hline Tianjin & 2.04 & -0.23 & 0.99 & 0.08 \\
\hline Hebei & 1.79 & 0.12 & 0.85 & -0.01 \\
\hline Shandong & 1.76 & -0.01 & 0.81 & -0.01 \\
\hline Shanghai & 2.12 & -0.57 & 0.97 & 0.10 \\
\hline Jiangsu & 2.27 & -0.20 & 1.07 & 0.19 \\
\hline Zhejiang & 2.51 & -0.12 & 1.22 & 0.31 \\
\hline Guangdong & 2.28 & -0.02 & 1.19 & 0.21 \\
\hline Fujian & 1.99 & -0.04 & 0.97 & 0.04 \\
\hline Hainan & 1.46 & 0.29 & 0.68 & -0.08 \\
\hline Shanxi & 1.87 & 0.53 & 0.99 & 0.20 \\
\hline Shaanxi & 1.70 & 0.14 & 0.81 & -0.01 \\
\hline Henan & 1.71 & 0.26 & 0.79 & -0.03 \\
\hline Anhui & 1.68 & 0.17 & 0.75 & -0.04 \\
\hline Jiangxi & 1.50 & 0.11 & 0.58 & -0.17 \\
\hline Hubei & 1.44 & -0.18 & 0.48 & -0.26 \\
\hline Hunan & 1.50 & 0.17 & 0.62 & -0.14 \\
\hline Guangxi & 1.38 & 0.06 & 0.50 & -0.24 \\
\hline Sichuan & 1.48 & 0.14 & 0.63 & -0.12 \\
\hline Guizhou & 1.30 & 0.22 & 0.45 & -0.24 \\
\hline
\end{tabular}

Source: Policy simulations. 
While all regions registered positive output deviations from the baseline following the tariff reductions, some regions' gains are above the national average and some below. The regions that have above national-average increases in regional output are Tianjin, Shanghai, Jiangsu, Zhejiang, Guangdong, and Fujian (Table 12.5). These regions accommodate exportoriented light manufactures that, as discussed above, benefited substantially from tariff reductions. In particular, Guangdong, which hosts the lion's share of the export clothing industry, registered the highest output deviation from the baseline, especially when the trade liberalization-related productivity growth is taken into account (Table 12.5).

The effects of endogenous productivity growth on regional employment have the most significant policy implications. When a region achieves a higher level of output following tariff reduction, we would expect it to also generate more employment. This is indeed the case without the endogenous productivity growth. The fourth column of Table 12.5 shows a pattern of labour force being drawn from relatively more agriculture-intensive regions to where the exportoriented industries are located, primarily the six regions that registered above national-average output gains. However, when the trade liberalization-induced endogenous productivity growth is taken into account, those six regions show negative employment deviation from the baseline (the second column of Table 12.5). This is mainly because that improved productivity means firms in these regions employ fewer primary factor inputs (including labour) per unit of output.

\subsection{Concluding comments}

This study suggests that China's tariff reductions for its WTO entry will lead to a much larger increase in real GDP if firms seek to improve their productivity when confronted with import competition. However, the regions that achieve larger (than national average) increases in output may not generate more employment as firms in these regions seek to use inputs (including labour) more efficiently.

While the gains from tariff reductions could be doubled by the presence of endogenous productivity growth, the estimated benefit is still only about 2 percentage points increase in GDP. Furthermore, the magnitude of the gains from the tariff reductions is likely to be much smaller than that presented in this study if various duty exemptions are taken into account.

The author believes that the real gain from China's WTO accession does not come from reductions in tariffs and non-tariff barriers. Tariff reductions represent only a small part of the policy reform in the context of China's accession to the WTO. The most important reform for the WTO accession is investment liberalization in the heavy manufacturing and key services industries (that is, the opening up of the industries currently dominated by state-owned enterprises to domestic as well as foreign private investment) (Mai 2001). The gains from the investment liberalization are much more dramatic (Mai et al. 2003). Compared with the benefits of investment liberalisation, the gains from 
tariff reductions are almost negligible. While tariff reductions deliver negative impacts on the motor vehicle industry, investment liberalization does the opposite. Investment liberalization in the context of China's WTO accession will deliver significant benefits to the heavy manufacturing industries, including the motor vehicle industry (Mai et al. 2003). 


\section{Yinhua Mai}

\section{Appendix A}

Table A.l Reductions in tariffs and tariff equivalents of non-tariff barriers and endogenous productivity improvements; percentage change between 2002 and 2006

\begin{tabular}{|c|c|c|}
\hline & $\begin{array}{l}\text { Reductions in tariffs and } \\
\text { tariff equivalents }\end{array}$ & $\begin{array}{l}\text { Endogenous productivity } \\
\text { improvements }\end{array}$ \\
\hline Grains & -6.81 & n.a. \\
\hline Other crops & -8.26 & n.a. \\
\hline Forestry & -10.02 & n.a. \\
\hline Livestock & -6.57 & n.a. \\
\hline Other agriculture & -8.26 & n.a. \\
\hline Fishing & -9.19 & n.a. \\
\hline Crude oil & -2.08 & n.a. \\
\hline Natural gas & -0.95 & n.a. \\
\hline Logging & -6.33 & n.a. \\
\hline Grain (milled) & -9.84 & 5.54 \\
\hline Meat processing & -7.04 & 3.03 \\
\hline Egg and dairy products & -7.04 & 0.13 \\
\hline Fish processing & -9.47 & 3.30 \\
\hline Sugar refining & -4.95 & 0.60 \\
\hline Other food products & -5.52 & 1.90 \\
\hline Wines & -20.23 & 4.23 \\
\hline Other beverages & -11.94 & 2.40 \\
\hline Tobacco & -11.94 & 2.40 \\
\hline Cotton textile & -8.12 & 8.03 \\
\hline Wool textile & -9.93 & 9.82 \\
\hline Hemp textile & -2.92 & 2.88 \\
\hline Silk textile & -8.36 & 8.26 \\
\hline Knitting mills & -11.12 & 11.00 \\
\hline Other textile manufacturing & -10.85 & 10.73 \\
\hline Clothing & -8.77 & 14.69 \\
\hline Leather products & -2.67 & 6.64 \\
\hline Sawmill products & -7.42 & 2.73 \\
\hline Furniture & -9.79 & 3.63 \\
\hline
\end{tabular}


Table A.1 Reductions in tariffs and tariff equivalents of non-tariff barriers and endogenous productivity improvements; percentage change between 2002 and 2006 (Continued)

\begin{tabular}{|c|c|c|}
\hline & $\begin{array}{l}\text { Reductions in tariffs and } \\
\text { tariff equivalents }\end{array}$ & $\begin{array}{l}\text { Endogenous productivity } \\
\text { improvements }\end{array}$ \\
\hline Paper products & -8.91 & 1.03 \\
\hline Printing and publishing & -2.08 & 0.23 \\
\hline Sports equipment & -7.79 & 10.96 \\
\hline Petroleum refining & -1.34 & 0.16 \\
\hline Coking & -1.49 & 0.18 \\
\hline LNG & -1.49 & 0.18 \\
\hline Basic chemical products & -2.57 & 0.64 \\
\hline Pesticide & -1.69 & 0.42 \\
\hline Organic chemical products & -3.79 & 0.95 \\
\hline $\begin{array}{l}\text { Household chemical } \\
\text { products }\end{array}$ & -8.73 & 2.23 \\
\hline $\begin{array}{l}\text { Synthetic chemical } \\
\text { products }\end{array}$ & -4.13 & 1.04 \\
\hline Other chemical products & -4.13 & 1.04 \\
\hline Pharmaceuticals & -6.10 & 1.54 \\
\hline Chemical fibre & -12.75 & 3.31 \\
\hline $\begin{array}{l}\text { Rubber products for } \\
\text { industry use }\end{array}$ & -2.43 & 0.60 \\
\hline $\begin{array}{l}\text { Rubber products for } \\
\text { household use }\end{array}$ & -2.43 & 0.60 \\
\hline $\begin{array}{l}\text { Plastic products for } \\
\text { industry use }\end{array}$ & -6.19 & 1.57 \\
\hline $\begin{array}{l}\text { Plastic products for } \\
\text { household use }\end{array}$ & -6.19 & 1.57 \\
\hline Cement & -0.35 & 0.17 \\
\hline Cement products & -1.59 & 0.76 \\
\hline Bricks and tiles & -2.52 & 1.21 \\
\hline Glass products & -2.82 & 1.35 \\
\hline Ceramic products & -11.57 & 5.70 \\
\hline Fireproof products & -3.55 & 1.71 \\
\hline $\begin{array}{l}\text { Other non-metallic mineral } \\
\text { products }\end{array}$ & -3.79 & 1.83 \\
\hline
\end{tabular}




\section{Yinhua Mai}

Table A.1 Reductions in tariffs and tariff equivalents of non-tariff barriers and endogenous productivity improvements; percentage change between 2002 and 2006 (Continued)

\begin{tabular}{|c|c|c|}
\hline & $\begin{array}{l}\text { Reductions in tariffs and } \\
\text { tariff equivalents }\end{array}$ & $\begin{array}{l}\text { Endogenous productivity } \\
\text { improvements }\end{array}$ \\
\hline Iron and steel & -4.27 & 1.15 \\
\hline Non-ferrous metal products & -1.19 & 0.16 \\
\hline $\begin{array}{l}\text { Metal products for industry } \\
\text { use }\end{array}$ & -3.16 & 1.78 \\
\hline $\begin{array}{l}\text { Metal products for } \\
\text { household use }\end{array}$ & -3.16 & 1.78 \\
\hline Boilers & -6.48 & 2.01 \\
\hline Metal work machinery & -1.84 & 0.56 \\
\hline Special machinery & -6.57 & 2.04 \\
\hline Agricultural machinery & -5.38 & 1.66 \\
\hline Household machinery & -6.57 & 2.04 \\
\hline Other special equipment & -1.54 & 0.47 \\
\hline Other machinery & -6.57 & 2.04 \\
\hline Railway equipment & -9.01 & 1.89 \\
\hline Motor vehicles and parts & -21.27 & 0.66 \\
\hline Ships and boats & -8.12 & 1.70 \\
\hline Aircraft & -9.52 & 2.00 \\
\hline Other transport equipment & -11.35 & 2.40 \\
\hline Generators & -5.33 & 1.65 \\
\hline $\begin{array}{l}\text { Household electrical } \\
\text { equipment }\end{array}$ & -7.70 & 3.24 \\
\hline Other electrical machinery & -6.05 & 1.87 \\
\hline Computers & -11.39 & 4.85 \\
\hline Electronic appliances & -10.07 & 4.26 \\
\hline Other electronic equipment & -6.29 & 1.95 \\
\hline Meters & -3.55 & 1.09 \\
\hline Other industry machinery & -5.95 & 8.40 \\
\hline Other household machinery & -5.95 & 8.40 \\
\hline
\end{tabular}

Source: Policy simulations. Column one is the author's calculation based on Table 4 in Mayes and Wang (2002). 


\title{
13 Raw entrepreneurship and the rise of the new private sector in western China
}

\author{
The Hope Group of Chengdu, Sichuan province
}

Marika Vicziany and Guibin Zhang

\subsection{Theoretical framework}

The work of Joseph Schumpeter on entrepreneurship has been severely neglected in recent decades. It is almost as if his prediction that the entrepreneurial function would become routine (and therefore no longer 'entrepreneurial' as he originally conceived of it) also became his own death wish in academic discourse. In fact, Schumpeter's predictions about the 'death' of entrepreneurship were not just premature but indeed based on a false conceptualization of the dynamics of late industrial and post industrial society. Despite the emergence of routine funding for $R \& D$, advanced industrial societies today have not provided a routine solution for the problem of how this $\mathrm{R} \& \mathrm{D}$ can be commercialized and serve the function of increasing productivity, which Schumpeter insisted was the key role of the entrepreneur and the essential ingredient of exponential growth as distinct from arithmetic growth. Exponential or dynamic growth requires innovative combinations of the factors of production, in contrast to arithmetic growth that arises from simply increasing the volume of inputs into production.

Schumpeter also had no idea how the Soviet planning model was going to influence development strategies in India and China after WWII. That pervasive planning model came to dominate development in the two largest and most populous economies in the world for the first thirty to forty years of the postcolonial era between 1950 and 1980/1990. During this period, the state itself emerged as the chief entrepreneur. Beyond building the basic infrastructure needed by undeveloped economies, this model proved to be insufficiently dynamic to take the large peasant economies of the world to the next stage of development. By the late 1970s China began to abandon the hallmarks of state planning for a new policy that stressed market mechanisms, trade liberalization and the rise of the private sector. India followed with similar policies about a decade later. As a result, during the last ten to twenty years, the private entrepreneur in China and India has re-emerged as the key catalyst for economic change and development. Schumpeter's predictions about the growing irrelevance of the traditional entrepreneur have proven to be spectacularly wrong. His predictions of the tendency of the capitalist order to 'destroy itself' and the 'likely heir apparent' being a socialist economic order are also very 


\section{Marika Vicziany and Guibin Zhang}

wrong today, although when he wrote his paper 'The March into Socialism' in 1950 it did look as if socialism in both the Keynesian and Leninist sense was the dominant global tendency (Schumpeter 1950: 448).

Today, Schumpeter's conceptualization of the entrepreneur and the entrepreneurial function in development has never been more relevant. First, Schumpeter distinguished between 'static' and 'dynamic' growth. The former was cyclical and depended on the rise and fall of business cycles as economic systems tended towards equilibrium. In contrast to this, 'dynamic' growth was 'spontaneous and discontinuous ... a disturbance of equilibrium, which forever alters and displaces the equilibrium state previously existing' (Schumpeter 2002: 64). Moreover static or cyclical growth depended on consumer tastes, in contrast to dynamic and discontinuous growth that was generated by fundamental changes in industrial and commercial production. For Schumpeter, it was the producer who created new consumer demands by changing the production system that could generate more commodities on an ever-expanding scale of inventiveness and efficiency. In seeing the relationship between the consumer and producer in this way, Schumpeter rightly predicted the rise of a whole new industry now known as 'marketing':

$\ldots$ the producer ... as a result initiates economic change, and consumers are educated by him [sic] if necessary; they are, as it were, taught to want new things, or things which differ in some respect or other from those which they have been in the habit of using. (Schumpeter 2002: 65)

Schumpeter's definition of discontinuous change rested on the argument that dynamic development required new combinations of the factors of production and that such new combinations had to be more than minor, gradual adjustments to the production process. He insisted that development demanded the emergence of a 'new phenomenon' or combination of production processes that were innovative in terms of at least one of the following five areas: a new product or quality, an innovative production or marketing process, the development of new markets, the harnessing of new supplies and production inputs, an innovative organization of management (Schumpeter 2002: 66). In stressing the innovativeness of these five key areas, Schumpeter also stressed that merely bringing additional resources into employment in order to increase output was not going to lead to dynamic growth of the discontinuous kind. Schumpeter used the metaphor of the body to clarify his meaning: ordinary, cyclical growth was like blood flowing in the normal channels of the body, while discontinuous, innovative growth required the channels of production to change into new directions. In an economic system, these new channels were inevitably new firms.

In Schumpeter's view, the factors that enable dynamic growth to occur were credit and entrepreneurs who act as the agents of change - they are the individuals who understand the benefits of discontinuous, dynamic growth and are willing to bring together the factors of production in new and unconventional ways. The entrepreneur has a distinctive, innovative role to play in the 
production process - namely to bring together new combinations of the inputs into production in order to raise productivity. As such the entrepreneur is different from a financier, manager, capitalist, factory owner, shareholder, creditor, risk bearer, promoter, or banker. All these other functions are distinctive from 'entrepreneurship' (Schumpeter 2002: 72-78). Moreover, the entrepreneur is not always entrepreneurial. He/she is only entrepreneurial at that point in time when he/she 'carries out new combinations' (Schumpeter 2002: 78). The moment the entrepreneur reverts to routine management or other tasks, he/she ceases to be an entrepreneur. The entrepreneur, according to Schumpeter, does not therefore exist as a social formation; rather he/she is the embodiment of the 'entrepreneurial function' when that function is activated and not at any other time (Schumpeter 2002: 78).

The final ingredient in Schumpeter's definition of entrepreneurship was the psychology of the entrepreneur - how the entrepreneur overcame internal resistance within him/herself to innovation and the natural tendency to conformity, how the entrepreneur dealt with the resistance of society to the inconvenience and challenge of doing things differently and deviating from the norm, and how the entrepreneurial function attracted persons with leadership qualities although entrepreneurship was a unique kind of leadership that had 'none of that glamour which characterizes other kinds of leadership' (Schumpeter 2002: 89). The lack of glamour was accompanied by the lack of those rewards that would appeal to hedonists (Schumpeter 2002: 92). The Schumpeterian entrepreneur was a remarkable creature: a social deviant driven by the need not merely to express his/her ego and ambitions, but to do so in a manner that radicalized the mundane production process and threw out the challenge to similar, dormant entrepreneurs to 'delight in change and new ventures' (Schumpeter 2002: 94). In summary, the Schumpeterian entrepreneur is a business leader who is willing to be a social-economic deviant for the short period of time required to introduce innovative, discontinuous changes in the production cycle in order to increase productivity and therefore generate dynamic growth as distinct from gradual, cyclical, static and incremental growth. Moreover, it is the entrepreneurial function within that 'entrepreneur' that is the primary consideration rather than that person's other economic functions that might range from management to financing and risk taking.

Despite its many positive attributes, the big weakness in the Schumpeterian conceptualization of innovative, exponential growth was his assumption that this would be funded by bank credit or, in Higgins's terminology, 'monetary expansion rather than ... current (ex ante) savings' (Higgins 1968: 135). What he did not foresee was the underdeveloped nature of the banking systems of poor, peasant economies such as Russia under the Tsars, India after decolonization and China after Mao. In these countries, Gerschenkron's explanation for how and why the state played the role of the entrepreneur is unassailable (Gerschenkron 1966). However, as the state withdrew from that historic role, the banks of India and China remained inadequate to the historical mission that was required of them, with the result that entrepreneurial families resorted to their own internal funding for development. Nor have the stock exchanges of Asia's large peasant production systems filled the void. As we will 


\section{Marika Vicziany and Guibin Zhang}

see, new firms in China today typically fund their original growth from their own internal savings. 'Internal' means personal savings and the savings of siblings, parents, members of the extended family, the clan and, where relevant, the caste.

Schumpeter's great strength, on the other hand, was the way he envisaged the cumulative impact of entrepreneurship. Clearly a single business leader acting on his or her own as an entrepreneur was a necessary but insufficient condition for pulling up the whole economic system onto a more dynamic, discontinuous platform. The first leader, in other words, had to attract other business leaders in taking up the entrepreneurial function. That process could start in a modest way with a single innovative factory, but that example had to motivate others to respond to the challenge of innovation. For Schumpeter, entrepreneurship could become more generalized by the demonstration effect of 'high monopoly profits' for early entrants into the new market together with the prerequisite that innovation begins in periods of economic stability when the risk of undertaking new ventures is minimal (Higgins 1968: 135). As noted, for Schumpeter the prime mover in the innovative production processes is the entrepreneur him/herself rather than the desires of the consumer market, which remain circumscribed until the business leader points the way to new, unexpected consumer goods. It is the generalized nature of business leadership and entrepreneurship that then stimulates the movement of the whole economy up onto a new platform of innovative and accelerated economic development what Higgins describes as a 'swarming' or 'clustering' of entrepreneurial activity. According to Higgins, Schumpeter provides the best theoretical explanation of how 'upswings begin in business cycles' (Higgins 1968: 135).

In this chapter, we use Schumpeter's theoretical framework because it provides the best insight into how and why new private enterprises have emerged in China. These 'green field' companies have nothing to do with state encouragement or the conversion of state-owned enterprises into new, non-state, collective enterprises. In particular, the social and psychological characteristics of the entrepreneur as described by Schumpeter are especially relevant to understanding why the Hope Group emerged once Deng Xiaoping made it clear that innovative business leaders would no longer be punished for being entrepreneurial.

\subsection{The growth of the private sector in post-Mao China}

The growth of the private sector in western China has been constrained by more than the usual difficulties. To begin with, in the Xinjiang Uighur Autonomous Region of China we have an economy that continues to be strongly controlled by the paramilitary or bingtuan, now called the Xinjiang Production and Construction Corps (hereafter XPCC). It has been estimated that at least 14 per cent of Xinjiang's GDP is generated by the XPCC. However, given the gross efficiencies of the bingtuan, this represents an underestimate of what the same investment of resources in alternative avenues might achieve. The XPCC has been the mechanism by which the state has pursued the 'black-white' economic 
policy of Xinjiang, a policy that seeks to promote economic development through cash crops like cotton and a resources sector based on coal and oil. The rise of the private sector in Xinjiang has also been hampered by development policies that pay insufficient attention to the needs of entrepreneurs from minority communities. Western China, more than the central and eastern provinces, contains numerous minorities that present the PRC with unique development opportunities and obstacles. These will be addressed in a new paper, but it is important to mention this characteristic of development in 'the west' partly because the Hope Group that is studied in this chapter does not come from a minority background and so represents the entrepreneurial possibilities for mainstream families. We also note that in contrast to the economy of the bingtuan in Xinjiang, Sichuan has actually benefited by interventionist state policies that saw the relocation of strategic and military industries to Chengdu from the more prone central and coastal provinces during the 1960 s.

Southwestern China has been economically backward in relation to more prosperous northern and coastal regions, and the growth of the private sector there has been constrained by more than the usual difficulties. The Hope Group grew up in the relatively nurturing environment of Chengdu, which was given many industrial and trading privileges by the state. The timing of the rise of the Hope Group was also propitious. Riding on the backs of quails and pigs, the Hope Group developed into one of China's first private multinationals. As China increasingly becomes integrated into the international economy we can look forward to hearing much more about the pigs and pig-feed that continue to underwrite the success of the Hope Group. Sichuan is the center of China's swine industry and as such competition between China (the world's largest pig producer) and the USA (the world's second largest producer of pigs) will focus on that state and involve that company. This competition will have widespread significance given the importance of the hog-corn production cycle to US domestic politics and the role of farm subsidies in the survival of America's farm sector.

The most recent survey of China's private sector states that between 1996 and 2001 the total number of private enterprises in China grew by almost half a million to about 1.3 million. This reflects an average annual growth rate of about 24 per cent. In the same five-year period, total private sector capital grew to 1406.8 billion RMB (up from 304.3 billion RMB), representing fourfold growth. In other words, the growth of private capital investment was even faster than the growth in the number of new businesses: about 36 per cent per annum. Not surprisingly, total turnover by private firms grew even faster - more than 50 per cent per annum. Moreover, and this is critical for economic development, the fastest growth in the number of private enterprises occurred in manufacturing, where value addition is typically higher than in primary industry (see Table 13.1). 
216 Marika Vicziany and Guibin Zhang

Table 13.1 Breakdown of private enterprises by sectors in 2002 (percentages)

\begin{tabular}{lrrrrr}
\hline SECTORS & 1989 & 1992 & 1997 & 1999 & 2001 \\
\hline Agriculture, Forestry, Fishery & & & 1.9 & 2.3 & 5.6 \\
Mining & 2.9 & 3.0 & 1.5 & 1.1 & 1.3 \\
Manufacture & 66.4 & 59.4 & 41.0 & 36.8 & 38.3 \\
Construction and real estate & 3.7 & 2.9 & 2.3 & 2.8 & 5.9 \\
Transport & 1.2 & 1.2 & 1.0 & 1.1 & 2.5 \\
Foods & 20.5 & 26.2 & 42.9 & 42.5 & 21.4 \\
Social services & 3.8 & 4.3 & 7.1 & 8.8 & 5.6 \\
Research and development & & 1.7 & & & 2.1 \\
Others* & 1.5 & 1.3 & 2.3 & 4.6 & 9.9 \\
Data missing in the original figures & & & & & 7.4 \\
\hline
\end{tabular}

Source: Calculated from China Private Enterprises Survey in China Private Economy Yearbook 2002, Figures 1-7.

Note

*Including consultancy services, such as accounting, auditing and business statistics.

Table 13.2 Geographical distribution of private firms (2001)

\begin{tabular}{llll}
\hline & Eastern China & Central China & Western China \\
\hline $\begin{array}{l}\text { Number of private firms } \\
\begin{array}{l}\text { Regional distribution of private } \\
\text { enterprises in China as \% of total } \\
\text { private firms }\end{array}\end{array}$ & 953,000 & 230,000 & 140,000 \\
$\begin{array}{l}\text { Annual growth of private sector as } \\
\text { measured by the number of new }\end{array}$ & $31.1 \%$ & $17.4 \%$ & $10.6 \%$ \\
$\begin{array}{l}\text { firms } \\
\text { \% of total land area of PRC }\end{array}$ & $11.2 \%$ & $11.0 \%$ & $18.2 \%$ \\
$\%$ of total population of PRC & $37.4 \%$ & $17.6 \%$ & $71.2 \%$ \\
\hline
\end{tabular}

Sources: Calculations based on Statistics from the State Statistics Bureau, scol.com.cn, June 2, 2003, http://www.scol.com.cn/economics/cjxw/20030602/20036285736.htm accessed 16 August 2003. Area and population data calculated from 'China's Provinces' http://www.chinaclub.de/english/chinaguide/prov.htm accessed on August 21, 2003.

Note

Includes all 31 provinces and regions in Mainland China but not Hong Kong.

Private enterprise grew throughout China, but as Table 13.2 shows, western China has lagged behind the eastern and central regions. In 2001, just over 10 per cent of the private firms of the PRC were located in western China, compared with 17 per cent in central China and 72 per cent in eastern China. 
How did these private-sector growth figures compare with the demographic distribution of China's population? Western China accommodated about 29 per cent of China's total people. In other words, the private sector in western China was grossly under-represented relative to population. Indeed with only 10 per cent of private firms located in the west, we can say that the private sector was under-represented by some 66 per cent. The private sector in eastern China by contrast was over-represented relative to the proportion of population: 72 per cent of China's private firms compared with 37 per cent of China's population. The private sector in western China, in other words, is far smaller and less dynamic than the population of the region would predict. Given that, it is not surprising that the GDP growth rate of western China has also been at least a third lower than that of eastern China. Central China's GDP growth has been even lower than that in western China, reflecting the intractable problems that define this old industrial 'rust' belt. It is important not to be naïve about China's regional problems: western China is not always the worst off by all criteria.

The growth of the private sector in China has been paralleled by the development of civil society. Civil institutions in western China are less numerous and weaker than their counterparts in the eastern coastal region. Recent work by Zhang Ye documents the proliferation and growing independence of Chinese NGOs, associations, international foundations and multinationals in China (Zhang 2003). For Beijing alone Zhang lists more than 260 NGOs of various kinds, the largest group being professional associations, trade unions and university associations (Zhang 2003: 13). Though he provides no breakdown of the total number of Chinese and foreign NGOs, the greater economic power of the Chinese military and paramilitary alone suggests that these institutions are much more constrained in western China.

The vast majority of private firms in China are the product of economic reforms undertaken in the state sector rather than totally new entrepreneurial ventures. The best explanation of this process is given in the International Finance Corporation Report (hereafter IFC) on the new policy adopted by central government in 1995. In official documents this was described as the zhuada fangxiao policy or 'keep the large ones and let the smaller ones go' (IFC 2000: 14). This policy required reforms at two levels: rationalization of the large firms that remained in the hands of the state, and conversion of small-scale public sector firms into private firms by restructuring their ownership. The latter gave rise to the 'gaizhi' or new non-state firms. The process of converting from state to private ownership involved various mechanisms, including contracting, leasing, the sale of firm assets to new private owners, and the establishment of cooperatives and private firms in which the previous employees had shares (IFC 2000: 14). As the IFC report argues, the process of reform was not inevitably based on privatization: privatization did occur, but not necessarily in all cases where employees shared in the assets and management of former state-owned enterprises. This is where foreign observers have become very confused, as it has typically been assumed that the end of state control and ownership must give rise to privatization. In the Chinese model, however, a third possibility exists: joint ownership of firms that are no longer state owned. This last can best be described as 'employee shareholding' or 'employee-held companies'. Moreover, 


\section{Marika Vicziany and Guibin Zhang}

many of these 'employee shareholding companies' are not managed by the employees but rather by the state - in which case they are not fully within the private sector as understood in the market economies of the west.

These distinctions are important because the present chapter about the Hope Group is a case study of a totally new private company that in the beginning had no connections at all to former state-owned or state-controlled enterprises. The Hope Group represents raw entrepreneurial talent engaged in innovative business developments and meets all the Schumpeterian definitions of entrepreneurship. In this chapter we use the notion of 'raw entrepreneurship' to distinguish between the new firms that form the most dynamic aspect of China's emerging private sector and those 'private firms' which were former stateowned enterprises. Once the company accumulated significant capital to diversify production it could benefit from the state sector by purchasing bankrupt state enterprises and from time to time encouraging state-backed organizations to invest in the business. But critically, in the Hope Group, we are discussing raw entrepreneurship unrelated to state enterprise, state capital, state management or even state encouragement.

\subsection{Chengdu's industrial growth and the private sector}

As noted, the Hope Group emerged in Chengdu, Sichuan province. Like much of western China, Chengdu has served important strategic interests since the revolution of 1949, after which Mao declared it to be the inland city to which the central government would retreat in the event of war. This was the 'Third Front' strategy, and the cold war mentality that gave rise to it has survived into the present day. When the heat of Beijing becomes unbearable and the water crisis severe, Beijing residents talk of the central government relocating to Chengdu.

The early industrialization of Chengdu was given a boost with the relocation of important strategic and military industries to this city during the 1950s and 1960s. Today this western city of about 10 million people is ranked the sixth most important city in the PRC. Located at the crossroads of the southernmost section of the ancient 'Silk Road', Chengdu has a long history of private entrepreneurship spanning hundreds of years; but all this was buried and forgotten until the late 1970s when the household responsibility system began to replace the Maoist communes. Deng Xiaoping, the architect of the reforms in the post-Mao era, came from near Chengdu and returned China to the familiar prerevolutionary tradition of private enterprise. According to Li Bing, Chief Secretary of the Private Association of the City Industrial and Commercial Management Bureau, the contribution of the private sector to Chengdu's GDP had risen to 41 per cent by the end of 2001 ('Chengdu: capacity building for private enterprises' 2003). This is an increase of 11 per cent since the 30 per cent figure reported by the International Finance Corporation's study in 1998 (IFC 2000: 3). The IFC report also gave a breakdown of the spread of private firms, which we can assume has not changed much since 1998. Chemicals, food and garment production each represented about 20 per cent of the total private enterprises in Chengdu, followed by metal and non-metal producing firms (14 
per cent), electronics (10 per cent, machinery (11 per cent), primary industries and miscellaneous industries each representing about 5 per cent (IFC 2000: 4, Table 1.1).

In 1990, Chengdu became one of China's first cities to be allowed to engage in foreign trade and attract foreign direct investment. As Kennedy notes, Chengdu grew by all indicators: foreign investment, GDP and urbanization. During the 1990s, the urban area of Chengdu virtually trebled (Kennedy 2003 Chapter 1). Many foreign countries established trade offices in Chengdu during that time - including the Australian Trade Commission, which opened a Chengdu office in 1998.

In 1994 the provincial government of Sichuan embarked on a policy of creating gaizhi - that is, converting SOEs into private firms. Four years later almost 70 per cent of the targeted government enterprises had been restructured and moved into the 'private sector'. According to the IFC, the restructuring process was dominated by the creation of cooperatives and employee shareholding firms - about half went in this direction. Another ' 19 percent were sold to other firms; 15 percent were contracted out or leased out, and 7 percent were liquidated' (IFC 2000: 16).

Behind the restructuring of state-owned enterprises, a more dynamic capitalism was also at work both in Chengdu and more generally in China. The geti gongshang $h u$ or firms with a single proprietor (distinct from group, collective or communal ownership) were growing in importance. Legally, only small enterprises with no more than 8 employees could register as a geti gongshang hu, but after 1988 larger firms were permitted to do so (IFC 2000: 8). Despite this, the ongoing ambiguity about the legal status of genuinely privately owned enterprises placed a premium on the private sector hiding behind collective enterprises. The IFC report discusses a number of ways in which entrepreneurs could benefit from displaying a 'collective' face to the banks and other state-controlled institutions that were resistant to privatization and therefore likely to stand in the way of entrepreneurial success (IFC 2000: 20-21).

We have cited the IFC study at length because it provides such a lucid account of how an economic system dominated by state owned enterprises has transformed itself quite rapidly into an increasingly private sector economy. What the IFC study does not address, however, is how, when and where totally new start-up and innovative individual private sector enterprises emerged namely firms that did not grow out of the transformation of state-owned enterprises. This is the great achievement of Tsai's Back-Alley Banking (2002), a book that addresses how the original accumulation of capital has happened in the new start-up private sector firms and how private entrepreneurship has won out over the ongoing obstacles presented by the state-owned sector or semi stateowned and managed sector. Specifically, BackAalley Banking has identified a wide variety of legal, semi-legal and illegal ways in which new start-up private sector firms funded their initial growth: interpersonal lending, trade credit, credit associations, pawnshops, rural cooperative foundations, shareholding cooperative enterprises, financial societies and capital mutual assistance 
associations, professional brokers and moneylenders, private money houses, and pyramid investment schemes.

\subsection{The rise of the Hope Group - a case study in raw entrepreneurship}

The Hope Group of companies is amongst the richest private companies in China today, and the four brothers and one sister that founded it and remain its CEOs are among China's richest individuals. In 2001, Rupert Hoogewerf compiled the third list for Forbes Magazine of 'China's Richest 100'. In that year, the Hope Group's Liu family displaced CITIC Pacific, which had been previously ranked as No.1 ('Blooms Amid the Boom' 2001). Less than twenty years earlier the Hope Group had begun by taking Deng Xiaoping's slogan 'to get rich is glorious' very seriously. The production and eating of quails had been banned under Mao as bourgeois indulgence, but in the early 1980s the ban was lifted and the company began to raise quail for meat and eggs. In developing their quail business the company focused on the local market of Sichuan. In the following sections we explain how the company expanded into pig feed production and how this formed the basis of their diversification into other areas of economic activity that eventually took them to the highest level of entrepreneurial activity and made them into the largest shareholders of China's only private bank.

\section{Phase 1: Entrepreneurship and the role of the local market}

In 1983, when the Liu brothers started their business of producing quail eggs, quail meat and quail stock, they were responding to Deng Xiaoping's assurances that economic liberalization in farm production and trade had become an essential plank in the official reform policies of the Communist Party of China. Moreover, the liberalization of trade and marketing in the livestock sector preceded liberalization of other areas of trade in farm produce (Bingsheng 1997: 4). In line with Schumpeter's predictions, these announcements by Deng Xiaoping had two immediate effects: first, the high risk associated with private production in China before the early 1980s vanished and second, the prospect of monopoly profits loomed for the first producers that dared to enter this formerly prohibited area of production.

The Liu brothers registered their business in the name of Yuxin Liangzhong Chang. The name was partly based on the name of one of the brothers (Yuxin) while the word Liangzhong Chang literally means a farm that raises 'an excellent breed (of quails)' (Interview, 20 August 2003). The original capital investment of $1,000 \mathrm{RMB}$ or US $\$ 120$ was raised by the brothers and one sister selling their own watches and bicycles. The quail business grew very rapidly from the small capital investment that quails required. In this it was aided by the rapid growing cycle of quail: they mature within 35 days.

The early success of the Liu brothers was based on their use of the local market, where they quickly established a brisk retail business in baby quails and 
quail products. Again in line with Schumpeter's predictions, innovative production began with the imagination of the Liu brothers and their sister who saw the opportunities that market reforms had opened up. The buyers in the local markets were in no position to influence decisions about production, because the whole business of eating quails and quail products had been firmly stereotyped as a ' bourgeois' indulgence by the previous Maoist regime. That regime's ultimate destructiveness had been expressed in the violence of the Great Proletarian Cultural Revolution, where people who painted their fingernails, admired Buddhist artefacts, read western literature, and behaved in other ways that Maoist extremists determined to be reflective of corrupt western or Mandarin cultural practices were victimized and even killed. China had not recovered from the trauma of the Cultural Revolution when the Liu brothers decided to go into the quail business. In this sense, they were very entrepreneurial and willing to take the financial risks of doing this - provided the Communist Party of China was indeed willing to shield them from the Maoist accusations that had been rife in the previous decades. At the same time, the Liu brothers clearly saw the benefits of monopoly profits as the just returns to early entrants into the quail business.

Just as Schumpeter's theory would predict, the example of the Liu producers in the Dong Qing Shu Free Market (designated by the Communist Party as the official market at which perishable consumer goods could be sold to the consumers of Chengdu city) brought many other quail producers into the field. As this occurred, the early monopoly profits to the Liu brothers began to decline. For example, during the first year or so of their business, baby quails sold in the local market for about $10 \mathrm{RMB}$ each. Thereafter the real price began to fall. Today baby quails still sell for $10 \mathrm{RMB}$ per bird in the Chengdu markets, but the real price is about $1 / 20^{\text {th }}$ what it was two decades ago (Interview, 12 December 2003). The financial returns to their initial investment allowed the Liu brothers to build a presence in the markets of other cities in Sichuan province. By 1986 they had established an extensive sales channel within Sichuan province, and increased the total turnover more than ten times (Interview, 1 December 2003).

By 1989 , the firm's total investment had reached 10 million RMB or US $\$ 1.2$ million. This growth occurred solely through the reinvestment of the firm's profits. Ploughing back earnings to facilitate the accumulation of capital and the growth of business has been identified as the source of finance for about 90 per cent of China's private sector; even older businesses found themselves relying on this as the main or only funding source (IFC 2000: 32). Tsai's wonderfully detailed study of Back-Alley Banking identifies other sources of private-sector funding and the dangerously blurred line between legal and illegal methods (Tsai 2002), but at this stage of our research it is too soon to comment on whether any of these methods were also used by the Hope Group. For the moment, the rise of the Hope Group conforms to the familiar pattern of familybased capital aided by growth and ploughed-back profits: the turnover and profits depended on the scale of the quail business; and large-scale production was possible because the firm involved five siblings who were willing to work together, share the burdens and reinvest their earnings. This early growth of the 


\section{Marika Vicziany and Guibin Zhang}

Hope Company in Chengdu is no different from the evolution of small private businesses in other parts of the capitalist world.

\section{Phase 2: Entrepreneurship and pig feed production}

As more and more producers entered the business of producing and selling quails and quail products, declining monopoly profits encouraged the Liu siblings to look to new business ventures. In the late 1980s they moved into the production of pig feed. At that time, the pig feed industry in Sichuan was dominated by Charoen Pokphand, a Thai company, one of Asia's largest multinationals (Chengdu Zhengda Company Ltd 2003). Clearly, Charoen Pokphand were making monopoly profits, given that there were no local challengers because the development of agri-industries had been held back by Maoist prohibitions on private enterprise.

Again, the Lius saw the opportunities for reaping monopoly profits. This time they had a sufficiently large capital base to take on the Thai multinational. The market entry strategy of the Liu siblings consisted of two main components: developing a new, highly nutritious pig feed that used quail droppings as an ingredient, and undercutting the local selling price of the Thai company's pig feed. In undercutting the Thai company's selling price, it is reasonable to assume that they were still making monopoly profits, because in Sichuan there were no other domestic Chinese firms capable of competing with the Liu siblings. The initial investment in the first pig feed factory established by the Hope Group was 10 million RMB, the total savings accumulated from their previous business in quail production. The first factory covered an area of 30 or 40 mou (about 2 to 2.6 hectares) with a special workshop area of about 2 thousand square meters (Interview, 20 August 2003). During the initial period of expansion every additional factory set up by the Hope Group required an additional investment of about 15 million RMB, of which about $2-3$ million RMB was set aside for R \& D to improve the quality of the pig feed (Interview, 20 August 2003).

Liu Yongxing has stated that the company always believed in research. $\mathrm{He}$ has cited his own college education in mathematics to explain why the Hope Group places a high value on knowledge, something that they believe gave the firm an edge over other farmers ('China's Richest Man' 2002). As Schumpeter suggests, spending money on routine $\mathrm{R} \& \mathrm{D}$ is not an entrepreneurial function. However, the early belief in establishing R \& D within the Hope Group system was a highly innovative idea and enabled the company to develop a mass market for pig feed at a time when farmers preferred to allow their pigs to eat any rubbish they could find by foraging. In this sense, then, Schumpeter's definition of entrepreneurship certainly applies to this early stage when the Hope Group developed a research infrastructure.

The timing of the Lius' entry into pig feed production was very important. Known as a chronic under-producer of grains before 1980, during the 1980s and 1990s China was generating regular grain surpluses. Given that grain is an essential input into the pig feed industry, these surpluses meant that the risks to pig feed production from crop failure were minimal. Farmers throughout China 
began to feed their pigs with grains, a policy encouraged by the Chinese government as a way of dealing with the grain surpluses. However, only a handful of innovative producers entered the modern pig feed industry at this time, largely because private firms in China lacked the capital base needed to establish factory production. The result of these combined factors was an enormous growth in swine production. According to Bingsheng, livestock as a share of total agricultural output doubled from 15 per cent to 30 per cent between 1975 and 1995 (Bingsheng 1997: 2). Most of this growth occurred in the swine sector. China produces more pigs and has more pig farmers than any other country in the world. That is partly because of the huge domestic demand and partly because some 80 per cent of China's 180 million farmers each have on average between two and three pigs (Bingsheng 1997: 2). Moreover, Sichuan has the country's largest concentration of pig farmers and is a net pig exporter to other provinces. The Lius had, in other words, located themselves in the middle of China's swine industry. Large-scale producers specializing in pig farming were also growing and already producing 20 per cent of total output by the time of Bingsheng's report in 1997. However, small-scale production continued to remain important and profitable for a number of reasons. Despite the grain surpluses pigs continued to eat the unwanted parts of the rice crop and sweet potato; they cleaned up the local scraps and rubbish; and they supplemented farmers' income. In Sichuan, pigs generated about 20 per cent of the cash earnings of local farmers (Bingsheng 1997: 3).

Pig meat production in China today continues to have the world's lowest input of grain feed. Despite this, the success of the Liu siblings was based on persuading enterprising farmers that investing in modern pig feed was worth the extra cost because the pigs grew faster, had fewer illnesses, and grew bigger than those feeding on conventional scraps and forage. The faster production cycle that produced more edible pork more than covered the costs of Hope Group pig feed and generated attractive net profits for enterprising farmers. As a result, the Hope Group sold modern pig feed to both small individual farmers and larger, commercial producers including the state farms that remained on the outskirts of China's cities. ${ }^{1}$

The details of modern pig feed production and husbandry were not known to China's small-scale pig feed producers and ordinary farmers during the 1980s. To create a new mass market for pig feed, the Lius had to turn their innovative skills in the direction of modern marketing. As Schumpeter proposes, entrepreneurship is not restricted to any particular economic activity; and in the case of the Liu siblings, mass marketing was an essential strategy if they wanted to expand their business beyond Sichuan. Their marketing campaign resorted to cheap advertising in the form of painted slogans on buildings in Sichuan and highway billboards between China's provincial capitals. The company's logo captures the essence of their two-pronged marketing strategy: 'If your pig eats one kilogram of Hope feed he will grow by two' (Erickson and Mooney 1997). 
224 Marika Vicziany and Guibin Zhang

Table 13.3 The economic cost of material and energy in the production of Hope pig feed

\begin{tabular}{llllll}
\hline $\begin{array}{l}\text { Material and } \\
\text { Energy }\end{array}$ & Corn & $\begin{array}{l}\text { Bean } \\
\text { Dreg }\end{array}$ & Fishmeal & Fuel & Electricity \\
\hline$\%$ of total cost & $40 \%$ & $25 \%$ & $4.75 \%$ & $0.56 \%$ & $1.02 \%$ \\
\hline
\end{tabular}

Source: Interview with New Hope spokesman by Guibin Zhang, 3 September 2003.

Note

Information about the role of quail droppings in this breakdown of the constituents of Hope pig feed is not available.

The Lius also developed a mystique about their pig feed formula. Legend has it that Hope Group pig feed is more successful than the feeds of competitors because it has a secret ingredient based on quail droppings. By linking their pig feed business to their earlier spectacular rise in the quail industry, the Liu brothers also created their own history of corporate success. The other ingredients of the Hope Group pig feed are familiar to global pig producers and include commercial grains (Table 13.3). Recent reports in Britain have analysed the economics of pig feed production and confirmed the experience of the Hope Group. Growing larger pigs is more productive than having more pigs because the meat yield can be increased without increasing overheads: for example, a large pig can live in a pen no different from a small pig or a number of small pigs yet the final pork output is higher. In other words, the advertising campaign of the Liu brothers was based on their own insightful observations about the logistics of housing and breeding pigs in confined spaces.

The decision to enter the pig feed market was, in retrospect, a rather spectacular one because it moved the Liu siblings into one of China's largest domestic markets and indeed one of the world's most competitive areas of production. About 80 per cent of the meat produced in China is pork. The strategy was dramatically successful. Within a year the Hope Group's monthly sales in Chengdu had risen to 4,500 tons, three times the volume sold by the Thai competitor. Thereafter the Thai competitor continued to face strong opposition from Hope in Chengdu. In 1997, Charoen Pokphand began a second price war with Hope, but lost heavily at a time when its other activities inside China were threatened by the Asian Financial Crisis (Vatikiotis et al. 1998). ${ }^{2}$

\section{Phase 3: Entrepreneurship, diversification and globalization ${ }^{3}$}

Once the Hope Group was well established in Sichuan's pig feed industry, they had the capital base to diversify beyond Sichuan - provided that their entrepreneurial ideas still had the momentum they displayed at the beginning of their business ventures. They clearly had not abandoned their entrepreneurial drive, and by purchasing 25 state-owned animal feed manufacturing plants throughout China they quickly established a national presence in agri-industry by 1997 (Erickson and Mooney 1997). Converting unprofitable state-owned enterprises into profitable private-sector factories demonstrated the managerial 
flair that the Hope Group had acquired. In the process they also developed expertise in related areas of economic management including real estate, hotel management and plant machinery, and a knowledge of the wider China market. This expertise provided the essential knowledge base on which to build further market diversification into, amongst other things, China's financial markets. By 1996, a mere 13 years since its foundation, the Hope Group was able to buy into the Mingsheng Banking Corporation, China's first private bank. Today they remain the bank's largest shareholder. Their banking venture also demonstrates how by 1996 the wealth and expertise of the Liu siblings were being taken very seriously by the Chinese government, which made the ultimate decision about whether a private firm might join the bank and, if so, which firm might do so.

Perhaps the Liu siblings' knowledge about their original Thai competitor in Sichuan province also made them more aware than other emerging Chinese entrepreneurs about the possibilities of business beyond national boundaries. In 2000, the Hope Group became a transnational business when it established two modern pig feed factories in Ho Chi Min city and Hanoi. The initial investment is estimated at US\$9 million. Today the company remains 100 per cent owned by the New Hope Group. The Vietnamese market exposed the Hope Group to opportunities to produce air-conditioning equipment. Their new company, Great Star Air Conditioner, imported components from China, assembled and then sold the final products in Vietnam. Within 12 months, New Hope had diversified into the Philippines market by setting up the Philippine Biotop company in 2001. Unlike other private sector initiatives, this was a joint venture with a local Philippines firm. It began production that year by generating a wide range of high quality animal, poultry and aquatic feed. The success of these cumulative diversification strategies was reflected in the doubling of the earnings of the Hope Group between 1992 and 2002 from 300,000 RMB to 550 million RMB (US\$66 million).

\subsection{Conclusion}

Schumpeter insisted that entrepreneurship was not a long-term phenomenon even in the case of the most entrepreneurially minded business leader. There was only 'the moment of entrepreneurship', a short-time period during which a business leader assumed an entrepreneurial function by combining the factors of production in such a way as to catapult output to unprecedented levels. Using this very strict Schumpeterian definition, one can say that the Liu siblings have acted as entrepreneurs again and again during the last twenty years. Their successes are based on thousands of entrepreneurial acts. Moreover, their willingness to embark on a wide range of adventurous and imaginative enterprises first in Sichuan, then in China and finally in the Asian region has required them to be entrepreneurial across a wide range of functions including finance, acquisition of real estate and other property, factory and asset management, exporting and importing, marketing, R \& D and even reforming and making productive former state-owned factories. Over a period of two decades they have sustained their energy and willingness to embark on risky 


\section{Marika Vicziany and Guibin Zhang}

business ideas, provided that the general policy climate in China remained favourable to the growth of private initiative. As such the emergence and successes of the Hope Group are a role model that should provide inspiration to other families in western China. The Hope Group and similar firms also need to be distinguished from other new private firms that are reformed state enterprises now managed by collectives of various kinds. In this way, the Hope Group represents the rise of raw entrepreneurial talent in modern China.

Despite the role of private entrepreneurship, there is still room for state policies to play a special role, especially in western China. The Liu siblings, as members of the Han ethnic group, did not suffer from any of the disadvantages that affect minority nationality groups wishing also to benefit by the new opportunities to 'get rich quick' in China. Special state policies and incentives are needed for minority communities.

\section{Notes}

1 These state farms persisted longer than others as a way of guaranteeing that the cities of China would be supplied with meat and other produce.

2 The CP group has bounced back in the Chinese market since the end of the Asian Financial Crisis. With 104 feed mills of a diversified kind, it is China's largest animal feed producer (Achara Pongvutitham 2003).

3 For a more detailed analysis of the diversification, internationalization and changed company structure of the Hope Group see Vicziany and Zhang (2003). 


\section{Bibliography}

Aboody, D. and Lev, B. (1998) 'The value relevance of intangibles: the case of software capitalization', Journal of Accounting Research, 36, Supplement: 161-169.

Abrahams, T. and Sidhu, B. (1998) 'The role of R\&D capitalisations in firm valuation and performance measurement', Australian Journal of Management, 23(2): 169184.

Abrahart, A. and Verme, P. (2001) Social Protection in Asia and the Pacific, Manila: Asian Development Bank.

Accounting Standards Board (1997) Financial Reporting Standard 10: Goodwill and Intangible Assets, London: Accounting Standards Board.

Achara Pongvutitham (2003) 'CP begins to turn the corner in China', The Nation, 3 June. Online. Available HTTP:

<http://www.siamfuture.com/ThaiNews/ThNewsTxt.asp?tid=1462>.

Aiken, M., Lu, W. and Ji, X.D. (1995) 'The new accounting standard in China: a critical analysis', in B. Blake and S. Gao (eds) Perspectives on Accounting and Finance in China, London: Routledge, pp. 159-177.

Alfredson, K. (2001) 'Accounting for identifiable intangibles - an unfinished standardsetting task', Australian Accounting Review, 11(2): 12-21.

All-China Federation of Trade Unions (ACFTU) (2003) Blue Paper on the Protection of the Legitimate Rights and Interests of Workers by Chinese Trade Unions, January. Online. Available HTTP: <http:www.acftu.org/m8.jsp?lmbh=7\&bh=468>.

Almanac of China's Finance and Banking, Beijing: Editorial Department of the Almanac of China's Finance and Banking, various issues.

Amsden, A. (1989) Asia's Next Giant, New York: Oxford University Press.

- (1991) 'Diffusion of development: the late industrializing model and Greater Asia', American Economic Review, 81(2): 282-286.

(1992) 'A theory of government intervention in late industrialization,' in L. Putterman and D. Rueschmeyer (eds) State and Market in Development: Synergy or Rivalry? Boulder: Lynne Rienner, pp. 53-84.

Amsden, A. and Hikino, T. (1994) 'Staying behind, stumbling back, sneaking up, soaring ahead: late industrialization in historical perspective', in W. Baumol, R. Nelson and E. Wolf (eds) Convergence of Productivity, New York: Oxford University Press, pp. 285-315.

Aoki, M. (1986) 'Horizontal vs. vertical information structure of the firm', American Economic Review, 76: 971-983.

- (1990) 'Toward an economic model of the Japanese firm', Journal of Economic Literature, 28 (March): 1-27. 
- (1995) 'An evolving diversity of organisational mode and its implications for transitional economies', Journal of the Japanese and International Economies, 9: 330-353.

- (1996) 'Towards a comparative institutional analysis: motivations and some tentative theorising', Japanese Economic Review, 47: 1-19.

Appleton, S., Knight, J. Song, L. and Xia, Q.J. (2002) 'Labor retrenchment in China: determinants and consequences', China Economic Review, 13: 252-275.

Armitage, C. (2003) 'China's "Iron Rice Bowl" gets the chop', The Australian, January 13 , p. 12.

Ash, L. (2002) 'Inside China's sweatshops', transcript of a BBC News Report, July 20.

Asian Development Bank (ADB) (2002a) 'Social protection: reducing risks, increasing opportunities'. Online. Available HTTP: $<$ http://www.adb.org/SocialProtection/default.asp.

- (2002b) The 2020 Project: Policy Support in the People's Republic of China: Final Report and Policy Directions, Manila: Asian Development Bank.

Asiamoney (2002) China supplement, December.

Asiamoney (October 2002). Online. Available HTTP: <http//www.asiamoney.com>.

Australian Accounting Standards Board (AASB) (1987) AASB 1011 Accounting for Research and Development Costs, Melbourne.

- (1995) SAC 4 Definition and Recognition of the Elements of Financial Statements, Melbourne.

- (1996) AASB 1013 Accounting for Goodwill, Melbourne.

Australian Financial Review (AFR) (2003) 16 October.

Baker, G. (2002) 'New avenue for M\&A transactions', South China Morning Post, 28 October.

Bang, H.C. (2002) 'The reform of Chinese state commercial banks: responding to China's WTO accession', unpublished Masters thesis, Seoul National University.

Bank for International Settlements (BIS) (1999) 'Options for China's financial system', BIS Policy Papers, 7: 321-34.

Barth, J.R., Caprio, G. and Levine, R. (2002) 'Bank regulation and supervision: what works best?' NBER Working Paper, 9323, November.

Barth, J.R., Dopico, L.G., Nolle, D.E. and Wilcox, J.A., (2002) 'An international comparison and assessment of the structure of bank supervision', SSRN Working Paper, 306764, February.

Barth, M. (2000) 'Valuation-based accounting research: implications for financial reporting and opportunities for future research', Accounting and Finance, 40: 7-31.

Barth, M. and Clinch, G. (1996) 'International accounting differences and their relation to share prices: evidence from U.K., Australian, and Canadian firms', Contemporary Accounting Research, 13(1): 135-170.

BBC News, 19 March 2002. Online. Available HTTP: <http://news.bbc.co.uk/>.

Beck, C., Demirguc-Kunt, R. and Maksimovic, S. (2002) 'Financing patterns around the world: the role of institutions', World Bank Policy Research Working Paper, 2905, October.

Becker, J. (2003) 'China's gestures of reform leave workers in chains', International Herald Tribune, 8-9, February, p. 8.

Bei Hu (2001) 'Narcissus shareholders sue CSRC, Shanghai exchange over delisting', South China Morning Post, 28 April.

- (2002a) 'Door opens to foreign investors', South China Morning Post, 8 November.

- (2002b) 'Company trio get suspended jail terms for fraud', South China Morning Post, 15 November.

_ (2002c) 'China listings for big firms', South China Morning Post, 20 November.

_ (2003a) 'Citigroup seeks QFII licence', South China Morning Post, 21 March. 
- (2003b) 'Fund poised to enter stock market', South China Morning Post, 3 June.

Bentley, D. (2003) 'Corporate governance: Asia plays catch-up', International Bar News, 57 (2), June, p. 18.

Betcherman, G., Dar, A., Luinstra, A. and Ogawa, M. (2000) Active Labor Market Programmes: Policy Issues For East Asia, Washington: The World Bank Group.

Bian, Y. (2002) 'Network resources and job mobility in China's transitional economy', Draft prepared for presentation at University of California, Davis, March.

Bingsheng, K. E. (1997) 'Recent Developments in the Livestock Sector in China and Changes in Livestock/Feed Relationship', FAO Discussion Paper. Online. Available HTTP: <http://www.nrsm.uq.edu.au>

Bloomberg, T. (2003) 'Motorcycle firm avoids expulsion', South China Morning Post, 1 September.

'Blooms Amid the Boom: the most successful entrepreneurs in the Middle Kingdom' (2001), Forbes.com, 11 December. Online. Available HTTP: $<$ http://www.forbes.com>.

Bonin, J. and Huang, Y. (2001) 'Dealing with the bad loans of the Chinese banks', Journal of Asian Economics, 12: 197-214.

Bonin, J. and Wachtel, P. (2003) 'Financial sector development in transition economies: Lessons from the first decade', Financial Markets, Institutions \& Instruments, 12(1): $1-66$.

Bottelier, P. (2003) 'Where is pension reform going in China? Issues and options', Perspectives, 3(5): 30-40.

Brown, G.D. and O'Rourke, D. (2003) 'The race to China and the implications for global labor standards', International Journal of Occupational and Environmental Health, 9: 299-301.

Buch, C.M. and Golder, S.M. (2001) 'Foreign versus domestic banks in Germany and the US: a tale of two markets?' Journal of Multinational Financial Management, 11(4/5): 341-361.

Burkett, P. and Hart-Landsberg, M. (2000) 'Alternative perspectives on late industrialization in East Asia: a critical survey', Review of Radical Political Economy, 32(2): 222-264.

Caijing [Finance and Economics] (2002), 71, 5 September.

Cai, S. and Deng, Y. (2002) 'Corporate governance: obstacles and new developments', South China Morning Post, 12 April.

Cavusgil, S.T. and Das, A. (1997) 'Methodological issues in empirical cross-cultural research: a survey of the management literature and a framework', Management International Review, 37 (1): 71-96.

Census Centre of the China Statistical Bureau (2003), China Statistical Bureau, Beijing.

Chan, A. (2001) China's Workers Under Assault: The Exploitation of Labor in a Globalizing Economy, Armonk: M. E. Sharpe.

Chand, S., McCalman, P. and Gretton, P. (1998) 'Trade liberalisation and manufacturing industry productivity growth', in Productivity Commission and Australian National University, Microeconomic Reform and Productivity Growth, Melbourne: AusInfo.

Chen, J.G. (ed.) (2001) China Social Security System Development Report, Beijing: Social Science Documents Publishing House.

Chen, J.P., Gul, F.A. and Su, X.J. (1999) 'A comparison of reported earnings under Chinese GAAP vs IAS: evidence from the Shanghai stock exchange', Accounting Horizons, 13(2): 91-111.

Chen, J.P., Chen, S.M. and Su, X.J. (2001) 'Is accounting information value-relevant in the emerging Chinese stock market?' Journal of International Accounting, Auditing \& Taxation, $10(1): 1-22$. 


\section{Bibliography}

Chen, L. (1990) 'Social development mechanisms and social security functions', International Sociology, 5(1): 89-100.

Chen, Y., Jubb, P. and Tran, A. (1997) 'Problems of accounting reform in the People's Republic of China', The International Journal of Accounting, 32(2): 139-154.

Chen, Z. (2003) 'Capital markets and legal development: the China case', China Economic Review, 14: 451-472.

Cheng, Y.S. and Lo, D. (2002) 'Explaining the financial performance of China's industrial enterprises: beyond the competition-ownership controversy', China Quarterly, 170: 413-440.

'Chengdu: capacity building for private enterprises', new.tfol.com, 19 Jan, 2003. Online. Available HTTP: <http://news.tfol.com/news/sichuan/block/html/ 2003011900011.html>.

'Chengdu Zhengda Company Ltd', Animal Feed Trade Fair. Online. Available HTTP: <www.caaa.com.an/zhansi/company/sic/wjzd.htm>.

Child, J. (1994) Management in China During the Age of Reform, Cambridge: Cambridge University Press.

China Daily, 30 January 2001; 28 July 2001; 7 August 2001; 24, 25, 28 September 2002; 8 October 2002; 27 December 2002. Online. Available HTTP: $<$ http://www1.chinadaily.com.cn/cndy/>.

'China's Richest Man' (2002) People's Daily, 23 January. Online. Available HTTP $<$ http://www.english.peopledaily.com.cn>.

China Mainland Marketing Research Company (CMMR) (2003) 'China urban hotspots investigation 2002', Beijing: China Mainland Marketing Research Company.

China Monthly Economic Indicators (2003) Beijing: National Bureau of Statistics of China, January 2.

China Research Centre on Ageing (1994) Report on the Implications of an Ageing Population on the Support Systems for the Elderly in Urban and Rural China, Beijing: CRCA.

China Statistical Abstract (2002) Beijing: China Statistical Press.

China Statistical Yearbook (2002), Beijing: National Bureau of Statistics of China.

China Youth Daily (2003) 'Shenzhen Municipal Government sets up Compensation System for State-owned firms', China Youth Daily, 15 July.

Chinese Central Television (CCTV) 2 (2003) Economic Information News, 11 July.

Choe, C. and Yin, X. (2000) 'Contract management responsibility system and profit incentives in Chinese state-owned enterprises', China Economic Review, 11: 98112.

Choi, F.D.S. and Lee, C. (1991) 'Merger premia and national differences in accounting for goodwill', Journal of International Financial Management and Accounting, 3(3): 219-40.

Chow, C.K.W. and Fung, M.K.Y. (2000) 'Evidence from Shanghai's manufacturing sector', Journal of Business Venturing, 15(4): 363-383.

Chow, P. (2003) Speech at the CFO Forum organized by the Hong Kong Society of Accountants on 'Improving Corporate Governance', 29 September. Online. Available HTTP: <http://www.hkex.com.hk/library/speeches/SP031030.htm>.

Citro, C. F. and Michaels, R.T. (eds) (1995) Measuring Poverty: A New Approach, Washington D.C.: National Academy Press.

Claessens, S. (1996) 'Banking reform in transition-countries', World Bank Working Paper, 1642, August.

Claessens, S., Djankov, S. and Xu, C. (2000) 'Corporate performance in the East Asian financial crisis', World Bank Research Observer, 15: 23-46. 
Claessens, S., Glaessner, T. and Klingebiel, D. (2002) 'Electronic finance: reshaping the financial landscape around the world', Journal of Financial Services Research, 22(1/2): 29-61.

Clarke, D.C. (2003) 'Corporate governance in China: an overview', China Economic Review, 14: 494-507.

Clarke, G., Cull, R., Martinez Peria, M.S. and Sanchez, S.M. (2002) 'Foreign bank entry: experience, implications for developing countries and agenda for further research', background paper prepared for World Bank, World Development Report 2002: Institutions for Development.

Collett, P., Godfrey, J.M. and Hrasky, S. (2001) 'International harmonisation: cautions from the Australian experience', Accounting Horizons, 15(2): 171-182.

Cook, S. (2002) 'From rice bowl to safety net: insecurity and social protection during China's transition', Development Policy Review, 20 (5): 615-635.

Cook, S. and Jolly, S. (2000) 'Unemployment, poverty and gender in urban China: perceptions and experiences of laid off workers in three Chinese cities', Poverty Research Programme, Institute of Development Studies Research Report 50, Department for International Development, UK.

Cornea, A. (2001) 'Globalization and health: results and options', Bulletin of the World Health Organization, 79: 834-850.

Croll, E. (1999) 'Social welfare reform: trends and tensions', China Quarterly, 159: 684 699.

Crystal, J.S., Dages, B.G. and Goldberg, L.S. (2001) 'Does foreign ownership contribute to sounder banks in emerging markets? The Latin American experience', in R. Litan, P. Masson and M. Pomerleano (eds) Open Doors: Foreign Participation in Financial Systems in Developing Countries, Washington D.C.: Brookings Press, pp. 217-266.

Dages, G.B., Goldberg, L. and Kinney, D. (2000) 'Foreign and domestic bank participation in emerging markets: lessons from Argentina and Mexico', Federal Reserve Bank of New York Economic Policy Review.

Dai, L. (1999) 'A general report on the research about the reform of social security system in China', unpublished report by Shanghai Research Institute of Social Security System, July 1999.

Dai, X. (2002) 'China's Banking Industry After WTO Accession', Speech to the Hong Kong General Chamber of Commerce, 18 February.

Davis, D. (1999) 'Self-employment in Shanghai: a research note', China Quarterly, 157, $22-44$.

DeMark, E. (2002) 'What do you need to know about new FASB pronouncements that target business combinations and goodwill', The CPA Journal, 72(2): 10.

Deng, X. and Smyth, R. (2000) 'Non-tax levies in China: sources, problems and suggestions for reform', Development Policy Review, 18: 391-411.

Ding, D. Z., Goodall, K. and Warner, M. (2000) "The end of the "iron rice-bowl": whither Chinese human resource management?' The International Journal of Human Resource Management, 11 (2): 217-236.

Dittmer, L. (2003) 'Leadership change and Chinese political development', China Quarterly, 176: 903-925.

Dixon, P.B., Parmenter, B.R., Sutton, J. and Vincent, D.P. (1982) ORANI: A Multisectoral Model of the Australian Economy, Amsterdam: North-Holland Publishing Company.

Dixon, P.B. and Rimmer, M.T. (2002) Dynamic General Equilibrium Modelling for Forecasting and Policy: A Practical Guide and Documentation of MONASH, Amsterdam: North-Holland Publishing Company. 


\section{Bibliography}

Dollar, D. (2001) 'Is globalization good for your health?' Bulletin of the World Health Organization, 79: 827-833.

Dong, K. and Ye, X.F. (2003) 'Social security reform in China', China Economic Review, 14: 417-425.

Dong, Z. (2001) 'Changes in the Structure of Ownership during the 50 Years in New China', Beijing: Union Forum, August 10. Available HTTP: http://www.cei.gov.cn/union/doc/1 hcasrep/200108010858.htm.

Dowling, C. and Godfrey, J.M. (2001) 'AASB 1037 sows the seeds of change: a survey of SGARA measurement methods', Australian Accounting Review, 11(1): 45-51.

Dziobek, C. and Pazarbasioglu, C. (1997) 'Lessons from systemic bank restructuring: a survey of 24 countries', IMF Working Paper, WP/97/161, December.

Erickson, J. and Hsieh, D. (1998) 'Sunrises in Shanghai: China's city of enterprise finds ways to employ the unemployable', Asiaweek, 24: 51-52.

Erickson, J. and Mooney, P. (1997) 'Hope takes on the world', Asiaweek, 10 October. Online. Available HTTP: $<\mathrm{http}: / / \mathrm{www}$.asiaweek.com>.

Estrin, S. and Rosevear, A. (1999) 'Enterprise performance and corporate governance in the Ukraine', Journal of Comparative Economics, 27: 442-458.

Fan, C. (2002) 'The Elite, the natives, and the outsiders: migration and labor market segmentation in urban China', Annals of the Association of American Geographers, 92: 103-124.

Fan, M. and Zheng, Y. (2001) 'The impact of China's trade liberalisation for WTO accession - a computable general equilibrium analysis', in P. Lloyd and X. Zhang (eds) Models of the Chinese Economy, Cheltenham: Edward Elgar Publishing Limited.

Fine, B. (1982) Theories of Capitalist Development, New York: Holmes \& Meier.

Fleisher, B.M. and Yang, D.T. (2003) 'Labor laws and regulations in China', China Economic Review, 14: 426-433.

François, J.F. and Spinanger, D. (2002) 'Greater China's accession to the WTO: implications for international trade/production and for Hong Kong', paper presented at the Fifth Annual Conference on Global Analysis, June 5-7, Taipei.

Frenkel, S. and Kuruvilla, S. (2002) 'Logics of action, globalization, and changing employment relations in China, India, Malaysia, and the Philippines', Industrial and Labor Relations Review, 55: 387-412.

Frydman, R., Gray, C. and Rapaczynski, A. (eds) (1996) Corporate Governance in Central Europe and Russia, Budapest: CEU Press, Volumes 1 \& 2.

Fu Jing (2002) 'Foreign firms to advise on work-safety', China Daily, January 31, p. 2.

Gao, Y. (ed) (2002) Report on China's Financial Market Development 2001, Beijing: Economics Science Press.

Garnaut, R. and Huang, Y. (eds) (2001) Growth without Miracles: Readings on the Chinese Economy in the Era of Reform, Oxford: Oxford University Press.

Ge, M. (1996) 'China's social insurance: reflections on predicaments and directions', in G. White and X. Shang (eds) Issues and Answers: Reforming the Chinese Social Security System (Papers from an International Workshop held in Beijing, October 1995).

Geiger, R. (2002) Foreign Direct Investment in China's Regional Development, Paris: OECD.

Gerschenkron, A. (1962) Economic Backwardness in Historical Perspective, A Book of Essays, Cambridge, MA: Harvard University Press.

- (1966) Economic Backwardness in Historical Perspective, Cambridge, MA: The Belknap Press of Harvard University Press.

Gilbert, J. and Wahl, T. (2002) 'Applied general equilibrium assessments of trade liberalization in China', World Economy, 25: 697-731. 
Godfrey, J. and Koh, P.S. (2001) 'The relevance to firm valuation of capitalising intangible assets in total and by category', Australian Accounting Review, 11(2): 3948.

Goldstein, G., Helmer, R. and Fingerhut, M. (2001) 'Mobilizing to protect workers' health: the WHO Global Strategy on Occupational Health and Safety', African Newsletter on Occupational Health and Safety, 11: 56-60.

Groves, T, Hong, Y., McMillan, J. and Naughton, B. (1994) 'Autonomy and incentives in Chinese state enterprises', Quarterly Journal of Economics, 109(1): 183-209.

_ (1995) 'China's evolving managerial labor market', Journal of Political Economy, 103: 873-892.

Gu, E.X. (1997) 'Foreign direct investment and the restructuring of Chinese state-owned enterprises (1992-1995): A new institutionalist perspective', China Information, 12: 46-71.

_ (1999) 'From permanent employment to massive lay-offs: the political economy of transitional unemployment in urban China (1993-98)'. Economy and Society, 28: 281-299.

_ (2001a) 'Dismantling the Chinese mini-welfare state? Marketization and the politics of institutional transformation, 1979-1999', Communist and Post-Communist Studies, 34: 91-111.

- (2001b) 'Forging a labour market in urban China: the legacies of the past and the dynamics of institutional transformation', Asian Affairs: an American Review, 28 (2): 106.

Guan, X. (2000) 'China's social policy: reform and development in the context of marketization and globalization', Social Policy \& Administration, 34 (1): 115-130.

Guan, X. (2001a) 'An analysis of the impact of globalization on China's social policies after China joins the WTO', The Chinese Economy, 34: 12-32.

Guan, X. (2001b) 'Globalization, inequality and social policy: China on the threshold of entry into the World Trade Organization', Social Policy \& Administration, 35 (3): 242-57.

Guangzhou Topper Human Resource Consultants (2003) Report of C\&B Survey (20022003 Guangzhou), Guangzhou: Guangzhou Topper Human Resource Consultants Co. Ltd.

Guoji Jinrongbao (2002), 24 July.

Hare, D. (1999) 'Push versus pull factors in migration outflows and returns: determinants of migration status and spell duration among China's rural population', Journal of Development Studies, 35: 45-72.

Hay, D., Morris, D., Liu, G. and Yao, S. (1994) Economic Reform and State-owned Enterprises in China, 1979-1987, Oxford: Clarendon Press.

He, F. (2002) 'Consequences on the health and safety of workers - From evidence to action of intervention', unpublished manuscript, Institute of Occupational Health and Poison Control, Chinese Center for Disease, Prevention and Control.

He, Z. (2003) 'To establish a unified, capable and flexible enterprise annuity administration management'. Paper presented at the Australia-China Sectoral Conference on Social Insurance, Ministry of Labour and Social Security, Shanghai, January 20-22.

Hickey, W. (2003) 'MNC pharmaceutical compensation in China: a predictor for human capital trends', Journal of General Management, 29 (1): 32-46.

Higgins, B. (1968) Economic Development: Principles, Problems and Policies, New York: W.W. Norton \& Co.

Hoegh-Krohn, N.E.J. and Knivsfla, K.H. (2000) 'Accounting for intangible assets in Scandinavia, the UK, the US, and by the IASC: challenges and a solution', The International Journal of Accounting, 35(2): 243-265. 


\section{Bibliography}

Holkeri, H. (2001) 'Globalization and its effects on occupational health and safety', African Newsletter on Occupational Health and Safety, 11: 55.

Holz, C. (2002) 'Long live China's state-owned enterprises: deflating the myth of poor financial performance', Journal of Asian Economics, 13: 493-529.

Holz, C.A. and Zhu, T. (2002) 'Assessment of the current state of China's economic reforms', The Chinese Economy, 35(3): 71-109.

Hong Kong Institute of Company Secretaries (2002) 'Independent Directors Crucial to Corporate Governance', News Release, 18 September. Online. Available HTTP: $<$ http://www.hkics.org.hk/whatsnew/>.

Horridge, M. (2001) 'ORANI-G: a general equilibrium model of the Australian economy', Edition prepared for the Yogyakarta CGE Training Course, Centre of Policy Studies, Monash University.

Hussain, A. (2000) 'The social role of the Chinese state enterprise', in M. Warner (ed.) Changing Workplace Relations in the Chinese Economy, London: Macmillan Press, pp. 57-76.

Hussain, A., Stern, H. and Stiglitz, J. (2000) 'Chinese reforms from a comparative perspective", in P. Hammond and G. Miles (eds) Incentives, Organization and Public Economics: Papers in Honour of Sir James Mirrlees, Oxford: Oxford University Press.

Hussey, R. and Ong, A. (2000) 'Can we put a value on a name: the problem of accounting for goodwill and brand', Credit Control, 21(12): 32-38.

Ianchovichina, E. and Martin, W. (2001) 'Trade liberalisation in China's accession to WTO', unpublished paper, Washington D.C.: World Bank.

International Finance Corporation (IFC) (2000) China's Emerging Private Enterprises: Prospects for the New Century, Washington D.C.: International Finance Corporation.

International Labour Organization (ILO) (1995) China in Transition: Towards a Better Workplace Environment, Bangkok: ILO Regional Office for Asia and the Pacific.

- (1998) 'China: promoting safety and health in township and village enterprises', ILO Regional Office for Asia and the Pacific, Bangkok. Online. Available HTTP: $<$ http:www.ilo.org/public/english>.

- (2002) 'Employment injury insurance', Preparatory Assistance Project Concept Paper No. 6, Beijing: Beijing ILO Office.

International Montetary Fund (IMF) (2001) Social Dimensions of the IMF's Policy Dialogue, Washington DC: IMF.

Interview (2003) with New Hope Group spokesperson, Chengdu, by Guibin Zhang. 20 August, 25 August, 3 September, 12 September.

Jaffee, D. and Levonian, M. (2001) 'The structure of banking systems in transition economies', European Financial Management, 7(2): 161-181.

James, E. (2001) 'How can China solve its old age security problem? The Interaction between pension, SOE and financial market reform', Journal of Pension Economics and Finance, 1(1): 53-75.

Jefferson, G., Hu, A.G.Z., Guan, X. and Yu, X. (2003) 'Ownership, performance, and innovation in China's large and medium size industrial enterprise sector', China Economic Review, 14(1): 89-113.

Jefferson, G. and Rawski, T. (1994) 'Enterprise reform in Chinese industry', Journal of Economic Perspectives, 8(2): 47-70.

Jiang, Q. (2002) 'Speech at the Meeting on Summarizing the Experience of Establishing Modern Enterprise Systems in Listed Companies' (Abstract), 27 December. Online. Available HTTP:<http://www.setc.gov.cn>.

Johnston, M.F. (2002) 'Elites and agencies: forging labour policy at China's central level', Modern China, 28: 147-176. 
Kapstein, E.B. (2000) 'Winners and losers in the global economy', International Organization, 54: 359-384.

Kennedy, J. (2003) 'Reconciling Economic Growth and the Environment: A Case Study of Chengdu, China'. Unpublished Masters Thesis, Monash University.

Khanna, T. and Palepu, K. (1997) 'Why focused strategies might be wrong for emerging markets', Harvard Business Review, 75(4): 41-51.

Knight, J., Song, L. and Jia, H. (1999) 'Chinese rural migrants in urban enterprises: three perspectives', Journal of Development Studies, 35: 73-104.

Krug, B. (ed.) (2004) China's Rational Entrepreneurs: The Development of the New Private Business Sector, London: RoutledgeCurzon.

Kynge, J. (2003) 'Observer in Beijing', Financial Times, 24 January, p. 14.

La Porta, R., Lopez-De-Silanes, F. and Shleifer, A. (2002) 'Government ownership of banks', Journal of Finance, 57(1): 265-301.

Lai, R. (1996) 'Red-chip bosses reap profits', South China Morning Post, 16 August.

Lam, T. F. K. (2000) 'Occupational Health and Safety in China', Asian Labour Update. Online. Available HTTP: <http://www.amrc.org.hk/alu>.

Langlois, J.D. (2001) 'China's financial system and the private sector', paper for Financial Sector Reform in China Conference, John F. Kennedy School of Government, Harvard University, 11-13 September 2001.

Lardy, N. (1998) China's Unfinished Economic Revolution, Washington D.C.: Brooking Institute Press.

Lawrence, S. V. (2002a) 'Ally of the people', Far Eastern Economic Review, 165(18), 9 May: 26-29.

- (2002b) 'Wielding a double-edged sword', Far Eastern Economic Review 165 (24), 20 June: 28.

Leckie, S. H. (2003) 'Pension reform in China', Pensions: An International Journal, 8 (2): $147-151$.

Lee, C. (1993) 'China's transition towards the market: socialisation of the safety net', China Economic Review, 4 (2): 169-180.

Lee, C.K. (1995) 'Production, politics and labour identities: migrant workers in South China', in S. Pepper and T. Yuen (eds) China Review 1995, Hong Kong: Chinese University Press.

- (1999) 'From organized dependence to disorganized despotism: changing labour regimes in Chinese factories', China Quarterly 57: 44-71.

Lee, G. O. M. and Warner, M. (2001a) 'Human resources, employment and labour-market policies in China: a comparative study of Shanghai and Hong Kong', Employment Relations Record, 1(2): 43-64.

- (2001b) 'Labour-markets in "Communist" China and "Capitalist" Hong Kong: convergence revisited', Asia Pacific Business Review, 8(1): 167-191.

- (2002) 'Labour-market policies in Shanghai and Hong Kong: a study of "One Country, Two Systems" in Greater China', International Journal of Manpower, 23(6): 505-526.

Lee, G.O.M., Wong, L. and Mok, K.H. (2002) 'The decline of state-owned enterprises in China: causes, issues and challenges', China Report, 37(2): 165-212.

Lee, H.Y. (2000) 'Xiagang, the Chinese style of laying-off workers', Asian Survey, 40: 914-937.

Lejour, A. (2001) 'China and the WTO: the impact on China and the world economy', in $\mathrm{X}$. Li and A. Lejour (eds) WTO Membership and Prospects of Chinese Economy, Beijing: China Financial Publishing House.

Leung, E., Liu, L., Lu, S., Taback, K. and Wang, L. (2002) 'Financial reform and corporate governance in China', MIT Sloan School of Management, $50^{\text {th }}$ 


\section{Bibliography}

Anniversary Proceedings, June 2002, Cambridge, Massachusetts. Online. Available HTTP: <http://www.mitsloan.mit.edu/50th/corgovchina/>.

Leung, J.C.B. (1994) 'Dismantling the "Iron Rice Bowl": welfare reforms in the People's Republic of China', Journal of Social Policy, 23: 341-361.

Leung, M.K., Rigby, D. and Young, T. (2003) 'Entry of foreign banks in the People's Republic of China: a survival analysis', Applied Economics, 35(1): 21-31.

Leung, R.L.C. (2003) 'China's evolving corporate governance', Company Secretary 13: (2), February: 16.

Lev, B., and Sougiannis, T. (1996) 'The capitalization, amortization, and value-relevance of R\&D', Journal of Accounting and Economics, 21: 107-138.

Lev, B. and Zarowin, P. (1999) 'Investment in R\&D and the declining value-relevance of R\&D', Working Paper, New York University.

$\mathrm{Li}, \mathrm{F}$. and Han, X (1994) 'Age groups and educational composition of peasants leaving for non-agricultural work: studies of rural labour migration', China's Rural Economy, 8: 10-14.

Li, J. and Yau, J. (2001) 'China's banking reform: a single step in a thousand-mile journey', International Journal of Business, 6(2): 87-110.

$\mathrm{Li}$, Jing (2001) 'State puts stress on safety', China Daily, December 20, p. 2.

$\mathrm{Li}$, S., Zhai, F. and Liu, Y. (2001) 'WTO membership and implications for China and its regional economies', in X. Li and A. Lejour (eds) WTO Membership and Prospects of Chinese Economy, Beijing: China Financial Publishing House.

Li, T. Y. (2000) 'Establish a social security system with Chinese features', in J.Z. Yin, S.L. Lin, and D.F. Gates, Social Security Reform: Options for China, Singapore: World Scientific, pp. 39-50.

$\mathrm{Li}$, X., and Lejour, A. (2001) 'The sectoral impact of China's accession to the WTO: a dynamic CGE analysis', in X. Li and A. Lejour (eds) WTO Membership and Prospects of Chinese Economy, Beijing: China Financial Publishing House.

Liang, Y.X., Fu, H. and Gu, X. Q. 1998. 'Provision of occupational health services in China', Asian-Pacific Newsletter 2, 1-9. Online. Available HTTP: $<$ http:www.ilo.org/public/english>.

Litan, R., Masson, P. and Pomerleano, M. (2001) 'Open doors: foreign participation in financial systems in developing countries', Brookings Institute Conference Report 6 , June.

Liu, X. (ed.) (2000) Work-related Injury Insurance, Beijing: China Labour and Social Security Publishing House.

Lo, D. (1997) Market and Institutional Regulation in Chinese Industrialisation 19781994, London: Macmillan.

(1999a) 'Reappraising the performance of China's state-owned industrial enterprises, 1980-96", Cambridge Journal of Economics, 23(6): 693-718.

- (1999b) 'The East Asian phenomenon: the consensus, the dissent and the significance of the present crisis', Capital and Class, 67: 1-24.

Lo, D. and Smyth, R. (2004) 'Towards a reinterpretation of the economics of feasible socialism', Cambridge Journal of Economics (forthcoming).

Loewenson, R. (2001) 'Globalization and occupational health: a perspective from Southern Africa', Bulletin of the World Health Organization, 79: 863-868.

London, L. and Kisting, S. (2002) 'Ethical concerns in international occupational health and safety', Occupational Medicine 17: 587-603.

London Stock Exchange (1997) The Listing Rules, London: International Stock Exchange of the United Kingdom and the Republic of Ireland, Ltd.

Lou, J. (2000) New China - Fifty Years Government Finance Statistics, Beijing: Economic Science Press. 
Lu, S. and Dai, G. (eds) (2002) Report on China's Financial Development 2002, Shanghai: Shanghai Finance and Economics University Press.

Ma, G. and Fung, B.S.C. (2002) 'China's asset management corporations', BIS Working Papers, 115, August.

McNally, C. and Lee, P. (1998) 'Is big beautiful? Restructuring China's state sector under the zhuada policy', Issues and Studies, 34(9): 22-48.

Mai, Y.H. (2001) 'China's WTO entry and reform of SOEs', in X. Li and A. Lejour (eds) WTO Membership and Prospects of Chinese Economy, Beijing: China Financial Publishing House.

(2003) 'Effects of reducing tariffs and endogenous productivity growth', CoPS Working Paper No. G-139, Centre of Policy Studies, Monash University. Online. Available HTTP: <http://www.monash.edu.au/policy>.

Mai, Y.H., Brown, S. and Feng, L. (1998) 'Trade liberalisation within a unilateral, regional and global context', in Y. Wu and Q. Ye (eds) China's Reform and Economic Growth, Canberra: NCDS Asia Pacific Press.

Mai, Y., Horridge, M. and Perkins, F. (2003) 'Estimating the effects of China's accession to the World Trade Organisation', paper presented at the 6th Annual Conference on Global Economic Analysis, June 12-14 2003, Scheveningen, The Netherlands.

Maurer-Fazio, M. (1995) 'Labour reform in China: crossing the river by feeling the stones', Comparative Economic Studies, 37 (4): 111-123.

- (2002) 'The role of education in determining labor market outcomes in urban China's transitional labor markets', William Davidson Working Paper 459, 1-24.

Mayes, D.G. and Wang, J. (2002) 'China after WTO membership - a CGE analysis of the impact of trade liberalisation', paper prepared for the UNU/WIDER Research Programme: 'The Impact of the WTO Agreement on Low Income Countries'.

Meng, X. (2000) Labor market reform in China, New York: Cambridge University Press.

- (2002) 'An overview of China's insurance market' (unpublished paper, China Insurance Regulatory Commission).

Meng, X. and Kidd, M. (1997) 'Labor Market Reform and the changing structure of wage determination in China's state sector in the 1980s', Journal of Comparative Economics, 25: 403-421.

Meng, Z. (2003) 'Social security funds management in China'. Paper presented at the Australia-China Sectoral Conference on Social Insurance, Ministry of Labour and Social Security, Shanghai, January 20-22.

Milanovic, B. (2003) 'The two faces of globalization: against globalization as we know it', World Development, 31: 667-683.

Ministry of Education (2003) Report on China's Education and Human Resources Problem, Beijing: Ministry of Education.

Ministry of Finance (MOF) (1992) Accounting Standards for Enterprises, Beijing: Chinese Economy and Finance Publishing.

- (1996) Notice on Permitting Foreign Accounting Firms to Establish Multiple Member Firms in China, 22 January.

- (2001) 'Intangible Assets', Accounting Standards for Business Enterprises, Beijing: China Financial \& Economic Publishing House.

Ministry of Justice of the People's Republic of China (2002) Stipulations of the Ministry of Justice Concerning the Enforcement of the 'Regulations on the Management of Representative Offices set up by Foreign Law Firms in China', 4 July.

Mok, K.H., Wong, L. and Lee, G.O.M. (2002) 'The challenges of global capitalism: unemployment and state workers' reactions and responses in post-reform China', International Journal of Human Resource Management, 13 (3): 399-415.

Montgomery, H. (2003) 'The role of foreign banks in post-crisis Asia', Asian Development Bank Institute Discussion Paper, January. 


\section{Bibliography}

Morris, J., Sheehan, J. and Hassard, J. (2001) 'From dependency to defiance? Work unit relationships in China's state enterprises', Journal of Management Studies, 38: 697717.

Muller, K.A. (1999) 'An examination of the voluntary recognition of acquired brand names in the United Kingdom', Journal of Accounting \& Economics, 26: 179-191.

Myers, S. (1977) 'Determinants of corporate borrowing', Journal of Finance Economics, 5: $147-175$.

Nobes, C.W. and Norton, J.E. (1996) 'International variations in the accounting and tax treatments of goodwill, and the implications for research', Journal of International Accounting, Auditing and Taxation, 5(2), 179-196.

Nobes, C.W. and Parker, P. (2002) Comparative International Accounting, London: Prentice Hall.

Nolan, P. (1996) 'Large firms and industrial reform in former planned economies: the case of China', Cambridge Journal of Economics, 20(1): 1-29.

- (2002) 'China and the global business revolution', Cambridge Journal of Economics, 26: 119-137.

- (2001) China and the Global Business Revolution, Basingstoke: Palgrave.

Nolan, P. and Wang, X. (1999) 'Beyond privatization: institutional innovation and growth in China's large state-owned enterprises', World Development, 27(1): 169200.

Nolan, P. and Yeung, G. (2001a) 'Big business with Chinese characteristics: two paths to growth of the firm in China under reform', Cambridge Journal of Economics, 25: $443-465$.

- (2001b) 'Large firms and catch-up in a transitional economy: the case of Shougang Group in China', Economics of Planning, 34: 159-178.

Nolan, P. and Zhang, J. (2002) 'The challenge of globalization for large Chinese firms', World Development, 30(12): 2089-2107.

Nyland, C., Smyth, R. and Zhu, C. (2004) 'What determines the extent to which employers will comply with their social security obligations? Evidence from Chinese firm level data', unpublished paper, Monash University.

OECD (2002) China in the World Economy: The Domestic Policy Challenges, Paris: OECD.

Office of the Western China Development, State Council of the People's Republic of China (2001) Opinions on the Implementation of Certain Policies for the Western Development, 28 August.

O'Neill, M. (2002) 'China warns of 20 million urban jobless'. South China Morning Post, 30 April, Section A, p. 1.

Organisation for Economic Co-operation and Development (OECD) (2002) China in the World Economy: The Domestic Policy Challenges, Paris: OECD.

Pan, P. (2002) 'Poisoned back into poverty: as China embraces capitalism, hazards to workers rise', Washington Post, August 4, p. A01.

Parker, C. (1997) 'Looking for the Australian approach', Australian Accountant, May: $44-48$.

Peek, J. and Rosengren, E.S. (2000) 'Implications of the globalization of the banking sector: the Latin American experience', FRBB New England Economic Review, September/October: 45-62.

People's Bank of China (2002) 'Stipulations on the Enforcement of the Regulations on the Management of Foreign Financial Institutions in the People's Republic of China', Beijing: People's Bank of China.

People's Bank of China, Chengdu Branch Project Team (2001) 'How to treat Sichuan's bank credit and deposit situation in recent years', Xinan Jinrong [Southwestern Finance], 7: 10-13 
People's Daily (2003a) Sweeping Banking Reform Launched in East China City, February 21.

People's Daily (2003b) CPPCC Calls for Improved Safeguards, July 10.

People's Daily (Renmin Ribao), 30 July 2001, 29 November 2001, 26 September 2002. Online, Available HTTP: (http://english.peopledaily.com.cn/)

Perkins, D.H. (2002) 'The challenge China's economy poses for Chinese economists', China Economic Review, 13(4): 412-418.

Piore, M. (1992) 'Technological trajectories and the classical revival in economics', in M. Storper and A. Scott (eds) Pathways to Industrialisation and Development, London: Routledge.

Poret, P. (2001) 'Making FDI and financial-sector policies mutually supportive'. Paper presented at OECD Global Forum on International Investment, Mexico City, 26-27 November.

Price, R.H. and Fang, L. (2002) 'Unemployed Chinese workers: the survivors, the worried young and the discouraged old', International Journal of Human Resource Management, 13 (3): 416-431.

Project Team, Institute of Foreign Economy and Division of Foreign Affairs, State Planning and Development Commission (SPDC) (2001) Study on the Impact of the Development of Cross-Border Mergers and Acquisitions on China's Economy and Policy Response, Beijing: SPDC, August.

Radebaugh, L.H. and Gray, S.J. (2002) International Accounting and Multinational Enterprises ( $5^{\text {th }}$ edition), New York: John Wiley \& Son, Inc.

'Rebiya Kadeer', AIUSA Honours Human Rights Champions. Online. Available HTTP: $<$ http://www.amnesty.usa.org/events/media_awards/media2000/awards_action4.htm $1>$.

'Rebiya Kadeer: mother jailed for mailing newspaper cuttings'. Online. Available HTTP: <http://www.amnesty.org.au/hrd_subsite/people/kadeer.asp>.

Roldos, J. (2002) 'FDI in emerging markets banking systems'. Paper presented at $O E C D$ Forum on International Investment, Mexico City, 26-27 November.

Sachs, J. and Woo, W.T. (1994) 'Structural factors in the economic reforms of China, Eastern Europe and the former Soviet Union', Economic Policy, 18 (April): 101145.

Saunders, P., Chalmers, J., McHugh, M., Murray, C., Bittman, M. and Bradbury, B. (1998) Development of Indicative Budget Standards for Australia, Policy Research Report No. 74, Department of Social Security, Canberra.

Saunders, P. and Shang, X. (2001) 'Social security reform in China's transition to a market economy', Social Policy and Administration, 35: 274-289.

Schauble, J. (2002a) 'Safety is a dirty word in China's mining industry', Sydney Morning Herald, July 12-13, p. 20.

- (2002b), 'Miners' bodies concealed after blast', The Age, July 3, p. 8. (2002c) 'China buries a deadly secret', The Age, July 31, p. 13.

Schiller, R. J. (2000) Irrational Exuberance, New York: Scribe Publications.

Schumpeter, J. (1950) 'The march into socialism', American Economic Review Papers and Proceedings, 40: 446-456.

- (2002) The Theory of Economic Development: An Inquiry into Profits, Capital, Credit, Interest, and the Business Cycle; trans. Redvers Opie, New Brunswick/London: Transaction Publishers.

Shanghai Statistical Bureau (2002), Shanghai Tongji Nianjian 2002 (Shanghai Statistical Yearbook 2002) (Shanghai: Shanghai Tongji Chubanshe).

Shi, S. and Weisert, D. (2003) 'Corporate governance with Chinese characteristics', Company Secretary 13(2), February, p. 10.

Shieh, S. (1999) 'Is bigger better?' China Business Review, May-June: 50-55. 


\section{Bibliography}

Shih, T. H. (2003) 'Mainland salaries for executives to top HK', South China Morning Post, 24 November.

Sito, P. (2002) 'New SOE rules considered short of foreign needs', South China Morning Post, November 28.

Slaughter, S. and May, S. (2003) 'Review of the role and effectiveness of non-executive directors - Higgs Report', Online. Available HTTP: $<\mathrm{http} /$ /www.slaughterandmay.com $>$.

Smith, A. (1776) [1976] An Inquiry into the Nature and Causes of the Wealth of Nations, E. Cannan (ed), Chicago: University of Chicago Press.

Smyth, R. (1997) 'A (re)interpretation of recent developments in the reform of stateowned enterprises”, China Report, 33(4): 507-525.

- (1998) 'Recent developments in the institutional reform of state-owned enterprises in mainland China', Issues and Studies, 34(8): 102-131.

(1999) 'Labour-market and social-welfare reform in the state-owned sector in China', Journal of Developing Areas, 33 (2): 223-244.

- (2000a) 'Old-age pension reform in China's state-owned enterprises', Journal of Aging and Social Policy, 11: 69-85.

- (2000b) 'Should China be promoting large-scale enterprises and enterprise groups?' World Development, 28(4): 721-737.

Smyth, R. and Lo, D. (2000) 'Theories of the firm and the relationship between different perspectives on the division of labour', Review of Political Economy, 12: 333-349.

Smyth, R., Wang, J. and Deng, X. (2004) 'Equity-for-debt swaps in Chinese big business: a case study of restructuring in one large state-owned enterprise', Asia Pacific Business Review (forthcoming).

Solinger, D. J. (1999) Contesting Citizenship in Urban China: Peasant Migrants, the State, and the logic Of the market, Berkeley: University of California Press.

_ (2001) 'Why we cannot count the "unemployed", China Quarterly, 167, 573-833.

- (2002) 'Labour market reform and the plight of the laid-off proletariat', China Quarterly, 170, 303-326.

- (2003) 'State and society in urban China in the wake of the $16^{\text {th }}$ Party Congress', China Quarterly, 176; 943-959.

Song, S. and Chu, G.S.F. (1997) 'Social security reform in China: the case of old-age insurance', Contemporary Economic Policy, 15: 85-93.

Standard and Poors (2003a) 'Asia-Pacific banking outlook 2003: swimming against strong currents', Mimeo, New York.

(2003b) 'China banking outlook 2003-2004', Mimeo, New York. (2003c) 'Asia-Pacific banking outlook 2004', Mimeo, New York.

State Statistical Bureau (SSB) (1998) Report on the First National Census of Basic Units, Beijing: National Bureau of Statistics of China.

(2002) Zhongguo Tongji Nianjian 2002 (China Statistical Yearbook 2002) (Beijing: Zhongguo Tongji Chubanshe)

- (2003a), scol.com.cn, June 2. Online. Available HTTP: <http://www.scol.com.cn/economics/cjxw/20030602/20036285736.htm>.

- (2003b) China Monthly Economic Indicators: June, Beijing: State Statistical Bureau.

(2003c) Report on the Second National Census of Basic Units, Beijing: National Bureau of Statistics of China.

- (various), Zhongguo Laodong Tongji Nianjian (China Labour Statistical Yearbook) (Beijing: Zhongguo Tongji Chubanshe).

Steinfeld, E. (1998) Forging Reform in China: The Fate of State-owned Industry, Cambridge: Cambridge University Press. 
- (2001) 'China's program of debt-equity swaps: government failure or market failure', Financial Sector Reform in China conference, Harvard University, Cambridge, MA, 11-13 September.

Steinfeld, E.S. and Hulme, V.A. (2000) 'Free lunch or last supper? China's debt-equity swaps in context', The China Business Review, 27(4): 22-27.

Stephens, C.H. (2003) 'Policy collisions - China's banking reforms require dramatic changes affecting many policies and sectors', Banking Law Journal, 120(34): 1-8.

$\mathrm{Su}, \mathrm{Z}$., Wang, S. and Levine, S. (2000) 'National occupational health service policies and programs for workers in small-scale industries in China', Aihaj, 61, 842-849.

Sutherland, D. (2001) 'Policies to build national champions: China's "National Team" of enterprise groups' in P. Nolan, (ed.) China and the Global Business Revolution, Basingstoke: Palgrave, pp. 67-139.

Tabachnick, B.G. and Fidell, L.S. (1989) Using Multivariate Statistics ( $2^{\text {nd }}$ Edition), New York: Harper Collins Publishers.

Tadesse, S. (2002) 'Financial architecture and economic performance: international evidence', Journal of Financial Intermediation, 11(4): 429-454.

Tam, O.K. (ed.) (1995) Financial Reform in China, London and New York: Routledge.

- (1999), The Development of Corporate Governance in China, Cheltenham, U.K. and Northampton, MA, USA: Edward Elgar.

- (2002) 'Ethical issues in the evolution of corporate governance in China", Journal of Business Ethics, 37: 303-320.

- (2004), 'Financing the private sector', in R. Garnaut and L. Song (eds), China's Third Economic Transformation: The Rise of the Private Economy London and New York: RoutledgeCurzon, pp. 118-132.

Tang, M. (2001) 'Insurance to protect those injured on the job', China Daily, April 1, p. 2.

Tanzi, V. (2002) 'Globalization and the future of social protection', Scottish Journal of Political Economy, 49: 116-127.

Tenev, S. and Zhang C. (2002) Corporate Governance and Enterprise Reform in China: Building the Institutions of Modern Markets, Washington D.C., World Bank.

Tenev, S., Zhang, C. and Brefort, L. (2002) Corporate Governance and Enterprise Reform in China, Washington D.C., World Bank.

Thelen, K. and Steinmo, S. (1992) 'Historical institutionalism in comparative politics', in S. Steinmo, K. Thelen and F. Longstreth (eds) Restructuring Politics: Historical Institutionalism in Comparative Analysis, Cambridge: Cambridge University Press.

Tian, R. (2003) 'Maximising the function of a trustee to facilitate social security system reform'. Paper presented at the Australia-China Sectoral Conference on Social Insurance, Ministry of Labour and Social Security, Shanghai, January 20-22.

Titmuss, R.M. (1974) Social Policy: An Introduction, London: Allen \& Unwin.

Tsai, K.S. (2002) Back-Alley Banking: Private Entrepreneurs in China, Ithaca: Cornell University Press.

Vatikiotis, M. with Granitsas, A. and Yatsko, P. (1998) 'Trouble at the mill: facing a crushing debt burden', May 28. Online. Available HTTP: <http://www.ibiblio.org/obl/reg.burma/archives/199805/msg00319.html>.

Vicziany, M. and Zhang, G. (2003) 'The pig-ishness of economic reform and globalisation: western China and the rise of the Hope Group'. Paper presented at 'Institutional Challenges for the Global China' conference, Faculty of Business and Economics, Monash University, Melbourne, Australia, November 13-14.

Wade, R. (1990) Governing the Market, Princeton: Princeton University Press.

Walder, A. (1986) Communist Neo-Traditionalism: Work and Authority in Chinese Industry, Berkeley: University of California Press. 


\section{Bibliography}

Walter, C.E. and Howie, F.J.T. (2003) Privatizing China: The Stock Markets and their Role in Corporate Reform, Singapore: John Wiley \& Sons (Asia).

Walter, I. (1993) High Performance Financial Systems: Blueprint for Development, Singapore: Institute of Southeast Asian Studies.

Wang, M.K. (ed.) (2001) Restructuring China's Social Security System: Funding, Operation and Governance, Beijing: China Development Publishing House.

Wang, Y. (2003) 'Exploring the strategic implications of the development of the private economy', China Industrial and Commerce Times, 10 July.

Warner, M. (1995) The Management of Human Resources in Chinese Industry, London, Macmillan and New York: St. Martin's Press.

- (1999) (ed.) China's Managerial Revolution, London: Frank Cass.

- (2000) (ed.) Changing Workplace Relations in the Chinese Economy, London and New York: Macmillan and St. Martin's Press.

- (2002) 'Globalization, labour markets and human resources in Asia-Pacific economies: an overview', International Journal of Human Resource Management, 13 (3): 384-398.

_ (ed.) (2003a) The Future of Chinese Management, London: Frank Cass.

- (ed.) (2003b) 'Special Issue: The future of Chinese management', Asia Pacific Business Review, 9 (2).

Webb-site.com (2002), 'Listing rules review, part 2: board games'. Online. Available HTTP: <http://www.webb-site.com/articles/boardgames.htm>.

White, G. (1998) 'Social security reforms in China: towards an East Asian Model?' in. R. Goodman, G. White and H.J. Kwon (eds) The East Asian Welfare Model: Welfare Orientalism and the State, London: Routledge, pp. 175-97.

White, G. and Goodman, R. (1998) 'Welfare orientalism and the search for an East Asian welfare model', in R. Goodman, G. White and H.J. Kwon (eds) The East Asian Welfare Model: Welfare Orientalism and the State, London: Routledge, pp. 3-24.

White Paper (2002) White Paper on Labour and Social Security in China. Online. Available HTTP: <http://www.china.org.cn/e-white/20020429/1.III.htm>.

Whiteford, P. (2003) 'From enterprise protection to social protection: pension reform in China', Global Social Policy, 3(1): 45-77.

Whiteley, A., Cheung, S. and Quan, Z.S. (2000) Human Resource Strategies in China, Singapore: World Scientific.

Wolfson, M. and Evans, J. M. (1989) Statistics Canada's Low Income Cut-Offs. Methodological Concerns and Possibilities. A Discussion Paper, Ottawa: Statistics Canada.

Wong, C. (1992) 'Fiscal reform and local industrialization: the problematic sequencing of reform in post-Mao China', Modern China, 18: 197-227.

Wong, C.K. and Lee, N.S.P. (2000) 'Popular belief in state intervention for social protection in China', Journal of Social Policy 29 (1): 109-116.

Wong, W. (2000) 'Impacts of globalization in contemporary China from occupational safety and health perspective'. Christian Industrial Committee.

Woo, W.T. (2002) 'Some unorthodox thoughts on China's unorthodox financial sector', China Economic Review, 13(4): 388-393.

World Bank (1990) China: Reforming social security in a socialist economy, Report 8074-CHA.

(1994) Averting the Old Age Crisis: Policies to Protect the Old and Promote Growth, New York: Oxford University Press.

- (1997) China's Management of Enterprise Assets: The State as Shareholder, Washington D.C.: World Bank.

_ (1997) China's Emerging Capital Markets, Washington D.C.: World Bank. 
_ (1997), China 2020. Old Age Security. Pension Reform in China, Washington D.C.: World Bank

World Economic Forum, (1998, 2003) The Global Competitiveness Report 2002-2003, New York: Oxford University Press

Wu, X. (2003) Speech to Fifty People's Forum on China's Economy, Diaoyutai State Guest House, Beijing, 17 January.

Xiao, S. (2001) 'Strategic restructuring of the state economy and the development of the non-state economy', China Review 41: 16-18.

Xie, P. (2003) 'China's Monetary Policy Transition: Year 1998 to 2002'. Paper presented at 'Institutional Challenges for the Global China' conference, Faculty of Business and Economics, Monash University, ', Melbourne, Australia, November 13-14.

Xinbian Gongye Tongii Gongzuo Zhinan (XGTGZ) (1999) A New Guide to Industrial Statistics, Beijing: China Statistical Press.

Xinhua News Agency (2002) "China to Cut Limits on Population Mobility", 25 February.

- (2003) "FDI in China Soars in First Five Months", June 13.

Xue, Y.G. and Wang, Z.T. (2002) 'The disclosure of intangible assets and value relevance: evidence from Shanghai stock exchange", Working Paper, Shanghai University of Finance and Economics.

Yao, S. (1997) 'Profit sharing, bonus payments and productivity: a case study of Chinese state-owned enterprises', Journal of Comparative Economics, 24: 281-296.

Yin, J. Z., Lin, S. and Gates, D. F. (2000) Social Security Reform: Options for China, Singapore: World Scientific.

Yiu, E. (2003) 'One-third of recent listing applications had disclosure problems', South China Morning Post, 30 May.

Zhai, F. and Li, S. (2000) 'The implications of accession to WTO on China's economy'. Paper presented at the Third Annual Conference on Global Economic Analysis, Melbourne, Australia, June 27-30.

Zhao, G. and Wang, T. (eds) (2002) Development of the Western Part of China and Capital Markets, Beijing: Social Science Literature Press.

Zhao, S. (1998) Human Resource Management in Chinese Enterprises, $2^{\text {nd }}$ edn, Nanjing: Nanjing University Press.

(2001) Research on Human Resource Management, Beijing: China People's University.

- (2003) Research on Human Resource Management Strategies in Chinese Enterprise Groups, Nanjing: Nanjing University Press.

Zhao, Y. and Xu, J.J. (2002) 'China's urban pension system: reforms and problems', Cato Journal, 21(3): 395-414.

Zhang, Y. (2003) China's Emerging Civil Society, Washington D.C.: Brookings Institution.

Zheng, Y. and Fan, M. (1999) A Chinese CGE Model and Its Application to Policy Analysis, Beijing: Social Sciences Documentation Publishing House.

Zhongguo Gongye Fazhan Baogao (ZGFB) (2000) China Industrial Development Report, Beijing: Economic Management Press.

Zhongguo Gongye Jingji Tongii Nianjian (ZGJTN) (various years) China Industrial Economics Statistical Yearbook, Beijing: China Statistical Press.

Zhongguo Laodong Shehui Baozhang Nianjian (ZLSHBZN) (2001) China Labour and Social Security Yearbook, Beijing: China Statistical Publishing House.

Zhongguo Laodong Tongji Nianjian (ZLTN) (various years) China Labour Statistical Yearbook, Beijing: China Statistical Publishing House.

Zhongguo Tongji Nianjian (ZTN) (2001) China Statistical Yearbook, Beijing: China Statistical Publishing House. 


\section{Bibliography}

- (various years) China Statistical Yearbook, Beijing: China Statistical Press.

Zhongguo Tongji Zhaiyao (ZTZ) (various years) China Statistical Abstract, Beijing: China Statistical Press.

Zhonghua Gongshang Ribao [China Business Times] (2002), 30 September.

Zhou, X. (2003) 'Financial system innovations: problems and challenges'. Paper presented at 'Forum on Financial System Innovations: Problems and Challenges', Institute of Finance, Chinese Academy of Social Sciences, 22 August.

Zhu, C. J. and Nyland, C. (2004) 'Globalization and social protection reform: emerging HRM issues in China', The International Journal of Human Resource Management (forthcoming).

Zhu, C. J., Nyland, C. and Yang, Z. C. (2004) 'Marketization, globalization and social protection reform in China: implications for the global social protection debate and foreign investors', Thunderbird International Business Review (forthcoming).

Zhu, Y. (2002) 'Recent developments in China's social security reforms', International Social Security Review, 55(4): 39-54.

Zoli, E. (2001) 'Cost and effectiveness of banking sector restructuring in transition economies', IMF Working Paper, WP/01/157, October.

Zou, C., Gan, Y. and Ma, Q. (1997) 'Pneumoconiosis in China: current situation and counter measures', Mineral Dusts and Prevention of Silicosis, 4, 1-10. Online. Available HTTP: <http:www.ilo.org/public/english>. 


\section{Index}

A-shares 50, 51

Aboody, D.: and Lev, B. 89

Abrahams, T.: and Sidhu, B. 89

Administration of the Takeover of

Listed Companies Procedures 49

aged: attitude changes and informal support 170-4; family support 173; financial transfers 173-4; National Surveys of the Aged Population in China 174 agency problems: cross-border environment 46-60

All-China Federation of Trade Unions (ACFTU) 133, 187-8, 196; Blue Paper (2003) 188

All-China National Working Commission on Ageing 162

All-China Women's Federation (ACWF) 133, 136

allocative efficiency 22, 23, 24 Anheuser-Busch Companies Inc (A-B) 50

Asian financial crisis (1997) 2, 224 asset-management companies

(AMCs): state-owned banks (SOBs) 29, 35-6, 43

Assets Supervision and Administration Commission (SASAC) 111

Association of Board Secretaries of Listed Companies 60

Australia 34, 82-104; Accounting for Goodwill 85; accounting for intangibles 83-8; identifiable intangible assets 85-6; pensions 163

Australian Accounting Research Foundation (AARF) 85

Australian Stock Exchange 90

Back-Alley Banking (Tsai) 219, 221

Baibang Community Service Company 132

Baibang Industrial Centre 132, 133

Bank of China: Shandong Province Branch 50

banking: foreign investors 66-7; internet 41-2

banking system 27-43; banking laws (1996) 34; benefits of foreign market entry 63-4; challenges 65-71; Chinese banking sector compared to regional E.Asia 31-43; credit management system 65 ; developments in bank reform process 28-30; informal banking sector 27; lack of professional bank supervisors $38-9$; restrictions of Chinese banks 37 banks: foreign $40,62-81$; government ownership 39; stateowned (SOBs) 27, 28-9, 34-6, see also foreign banks; People's Bank of China; South America banks

Barth, M.: and Clinch, G. 90

Beijing Social Psychology Research Institute 146 
Beijing Tianzhu Airport Industrial Zone 193; insurance and safety issues 193-4

Bian, Y. 128

Bottelier, P. 159

business environment: changing 148

CAMEL framework: assessing domestic bank strength 67-8

Canadian Bank of Nova Scotia 79

capital markets: emerging 82-104

Central Bank 29

Chengdu: Australian Trade

Commission 219; private sector

and industrial growth 218-20

Chengzihe coal mine: explosion 178

China: accession to World Trade

Organization 1, 2, 30, 48, 106,

137, 155, 192, 199-207;

accounting for intangibles 88-9;

business reform 1-10;

implications of accession to

World Trade Organization 9-10;

reform of economy 1-10

China Banking Regulatory

Commission 29, 80

China Bureau of Statistics 200

China Insurance Regulatory

Commission 80

China Mainland Marketing

Research Co.(CMMR) 143

China National Committee on

Ageing (CNCA) 162

China Oilfield Services 46

China Research Centre on Ageing

(CRCA) 162, 171

China Securities Regulatory

Commission (CSRC) 47-8, 80

China Telecom 46

China Women's College 144

Chinese Academy of Social

Sciences 200

Chinese Accounting Standard for

Enterprises 82, 88

Chinese Central Bank 76, 79
Chinese Enterprise Directors

Association 188

Chinese enterprises: changing structure 106-23

Chinese listed companies: independent directors 53-60; supervisory committees 58-9

Citibank Group 70, 79

CITIC 67

Civil Procedure Law: China 52

Claessens, S. 27

Clinch, G. and Barth, M. 90

clothing industry 203

collective village and township enterprises (CVTEs) 182, 184, $185,187,188$

college graduates 107

command socialism 139

Communist Party 6, 16, 125, 127

Company Law: Chinese 51-3;

Hong Kong 51

company secretary 60

COMPUSAT 90

computable general equilibrium

(CGE) literature 9-10

contract management system 19

Cook, S.: and Jolly, S. 144-5

Cornea, A. 179

corporate governance 2-5

corporatization of state-owned

enterprises (SOEs) 19, 20

credit markets: informal 29

Cronbach's alpha coefficient 148-9

Czech Republic 28

Datastram 90

Deng Xiaoping 106, 214, 218, 220

diversification: entrepreneurship and globalization 224-5

division of labour: detailed 23-4;

social 23-4

Dollar, D. 179

domestic firms: cost of finance 28

Dong Qing Shu Free Market 221

downsizing drive: state-sponsored 21,26

Dziobek, C. and Pazarbasioglu, C. 27 
East Asian financial crisis 25 East Asian industrialization 21 Eastern Europe 40

EBucks: internet banking 41

Economist Intelligence Unit 200

employee shareholding 217

employment and unemployment: policy responses $124-38$

Engel's Law 167

Enron 3

enterprise ownership: changes in structure 110-13

enterprise reform: four stages 19-20

enterprise stakeholders 20 -1

enterprises: foreign-invested 111 ; manufacturing 111

entrepreneurship: diversification and globalization 224-5; and the new private sector; Western China 211-26; and pig feed production 222-4; role of local market 220-2; Soviet planning model 214

equity-for-debt swap (EDS) scheme 4

Ericsson 193

Everbright 67

exports 107

Fang, L.: and Price, R.H. 142

financial reform 2-5

financial statements: relevance in developed and emerging capital markets 82-104

firms: mixed ownership 111

FirstRand Bank 41

Forbes magazine 10

foreign bank entry 71-81; entry mode 72-6; establishment of bank branch 73-4

foreign banks: economic and market impacts 67-70; effect on domestic banks 70; impediments to expansion 76-80; insurance industry experience 70-1; market entry and foreign investment 62 81 foreign direct investment (FDI) 636,80

foreign investors: banking services 66-7

foreign-invested enterprises (FIEs) $140,146,149-50,153-5$

GDP growth 31, 217

Global Depository Receipts 46

globalization 1, 3, 10;

entrepreneurship and

diversification 224-5; and

occupational health and safety

regulation 177-97

Godfrey, J.: and Koh, P.S. 90, 97, 104

Goldstein, G. et al 179

Goodman, R.: and White, G. 161

Great Proletarian Cultural

Revolution 221

Great Star Air Conditioner 225

Gu, E.X. 142

Guangdong 206

Guangdong Academy of Social Science 196

Guangzhou P\&G Co. Ltd. 122

H-shares 46-7; approved companies 50; companies 54

Haier Group 122; Human Resource Development Center studies 122

Hanoi 225

Heilongjiang Province: Dingsheng coal mine explosion 186

Ho Chi Minh City 225

Holz, C. 12

Hong Kong 31, 34, 43; Chinese company listings 46-60

Hong Kong Securities Commission 51

Hong Kong Society of Accountants 57

Hong Kong Stock Exchange

(HKSX) 3, 46; listing rules 47, 51

Hope Group 9, 214-26; Liu

brothers 220; rise of 220-5

Hu Jintao 10 


\section{Index}

human resource management 1 , 106-23; compensation system 116; current situation 115-21; housing 114-15; performance evaluation 116; personal file 114; recent challenges 113-23; recruiting 115; residency card 113-14; in Shanghai 124-38; social security system 14 ; successful cases 122-3; training 115-16

human resources 5-6; three irons policy 5

Hungary 28

imports 107

independent directors: Chinese listed companies 53-60; guidelines of Chinese Securities Regulatory Commission (CSRC) 55-8; lack of qualified manpower $59-60$

industrial restructuring: observations and reinterpretation 13-16; state-owned enterprises (SOEs) 11-26

Institute of Development Studies 144

institutional reform 16-25; enterprise-level reform 19-21

institutions: comparative efficiency attributes 21-5

insurance industry: foreign competition 70-1

intangible assets: accounting in China and Australia 82-104; brand names $87,92,99$; deferred costs 87-8, 99; goodwill 85, 92 , 99; licence costs $88,92,99$; research and development 86-7, $92,97,99,104$; research and development costs 86-7, 89-90, 92; value relevance in Australia and China 99-104

Interim Provisions for Foreign Investors to Merge Domestic Enterprises 49
Interim Regulations on Occupational Injury and Disease Insurance (1996) 189

International Accounting Standards Board (IASB) 83, 85, 86

International Finance Corporation Report (IFC) 217, 218, 219

International Financial Reporting Standards (IFRS) 85

International Labour Organization (ILO) 179, 180, 183

International Monetary Fund (IMF) $43,83,177$

iron armchair 181

iron rice-bowl (tie fanwan) 124, $128,134,141,148,181$

James, E. 159

Japan: main bank system 22; Meiji era (1868-1912) 23

Jiang Zemin 10

Jilin: coal mine explosion 178, 185

Jolly, S.: and Cook, S. 144-5

JVC 193

Khanna, T.: and Palepu, K. 18

Kisting, S.: and London, L. 179, 181

Koh, P.S.: and Godfrey, J. 90, 97, 104

Labor Law 115

labour market: institutional changes 127-9

labour market model: Shanghai 129-34

labour market reform 5-6

Lam, T.F.K. 186

large-scale industrial enterprises (LEs) 12, 13, 25

late industrialization 17-18; East Asian model 17

Latin America 40

Law for the Promotion of Small and Medium-sized Enterprises 113

Lev, B.: and Aboody, D. 89; and Sougiannis, T. 89

Liaoning Province 160 
listed Chinese companies: lack of committee system 57-8

Lo, D. 12

loans: difficulty for private enterprises 112

Loewenson, R. 179

London, L.: and Kisting, S. 179, 181

London Stock Exchange 90

Mandatory Provisions (Hong Kong) 53, 58; individual shareholder rights 52-3; shareholders' meeting 51-2

Mao Tse-tung 141

marketization 1, 10, 142, 181, 185 , 192, 195, 197; progressive 16

Mexico 177

Mingsheng Banking Corporation 225

Ministry of Finance 29, 80, 88; accounting standards system 8 Ministry of Labour and Social Security 137, 180, 183, 184, 189; Social Administration Bureau 190, 191; Work Injury Insurance Division 192

Ministry of Social Welfare 132 minority shareholders' protection 51-3

modern enterprise system 17

Mok, K.H. et al 145

Morris, J. et al 181

Motor Vehicles industry 201, 203

Motorola 193

National Social Security Fund (NSSF) 49, 160

New York 46

NewBridge Capital Group 79

Nolan, P. 12; and Wang, X. 18 non-performing loans (NPLs) 28, $34,35,43,63,65,69$

occupational and health and safety: Chinese figures 182-4 occupational health and safety: employer groups and trade unions 187-8; foreign culture on safety 194-5; laws 8; standards and ownership forms 195 ; work accident insurance in a multinational enterprise 193-5 occupational health and safety regulation: and globalization 177 97; occupational insurance reforms 180-1; policies to increase awareness 189; protection of migrant workers 186-7; recent reforms 184-9 one-child family: policy 157 Open Door policy 10

Palepu, K.: and Khanna, T. 18

Panasonic 193

Parmalat 3

Pazarbasioglu, C.: and Dziobek, C. 27 pension reform 157-75; double burden dilemma 161; expenditures on necessities 167; living arrangements 163-4; mean incomes 165-6; review of recent reforms 159-62; subjective wellbeing 168; well-being of the aged 163-70

pensions: pay-as-you-go (PAYG) 160

People's Bank of China 28, 29, 50 , 67, 80

People's Construction Bank of China: Qingdao Branch 50 personnel management: history in China 107-9; three irons policy 108 petroleum extraction industry 16 pharmaceuticals industry 22 Philippines 225 pig feed production: economics of 224; and entrepreneurship 222-4 pneumoconiosis 184

Pokphand, C. 224

Poland 28

poverty 145

Price, R.H.: and Fang, L. 142 
250 Index

private sector: and entrepreneurship

in W.China 211-26; growth 9; growth in post-Mao China 21418 ; and industrial growth

(Chengdu) 218-20

privately owned enterprises (POEs)

146, 153-5

privatization 217

profit retention reform 19

Qingdao State-Owned Assets

Administration Office 51

Qingdao State-Owned Assets

Bureau 50

Qualified Foreign Institutional

Investor (QFII) 49

Regulations on Labour Insurance

in China (1951) 189

Ren Mi Bin: lending 30;

transactions 30

Russia 43, 177; mass privatization 2

Sample Survey of the Aged

Population in Urban and Rural

China 162

SARS virus 107

Schumpeter, J. 211-14, 220-1, 225;

March Into Socialism 212

Securities and Futures Commission 47

Shanghai: Labour and Social Security Bureau 129, 132; Reemployment Service Centre 129, $133,135,136$; social protection reform 139-56

Shanghai labour market model 12934 ; creation of employment 131-

3 ; job referral and counselling 133-4; retraining 131

Shanghai Pudong Development Bank 79

Shanghai Workers Mutual

Association (SWMA) 154

Shantou 187

Shanxi 187; gold mine explosion 186 shareholder accountability 24

shareholders: non-state 48

shareholding enterprises (SHEs)

140, 146; expansion 13-14

Shenzen Development Bank 79

Shenzhen 187

Shenzhen Municipal Government

116

Shi Baoquan 181

Shieh, S. 18

Shougang 22

Sichuan 225

silicosis 184

Singapore 31, 34, 43

Smith, A. 23

social insurance policies 153

social insurance regime 7

social protection: role of trade

unions 154-5

social protection policy:

determinants of employee

satisfaction 151-2

social protection reform 8 ; changes in ownership structure 140-2;

Shanghai employee perceptions 139-56; Three Security Lines policy 155; Two Guarantees policy 155

social security system 7

social welfare reform 7-8

societalization (shehuihua) 141

Sougiannsi, T.: and Lev, B. 89

South America: bank study 69

South Korea 28, 31

special economic zones (SEZs)

187

stakeholder accountability $21-2$;

corporate governance structure 24

State Administration of Foreign

Exchange 80

State Administration of Work

Safety $180,183,184,185,186$,

188, 189, 190, 194

State Bureau of Coal Mine Safety 184

State Council's Development

Research Centre 126 
State Economic and Trade Commission (SETC) 184, 185, 188

State Restructuring Commission 51

State Statistical Bureau 143

state-owned big business 16-19 state-owned enterprises (SOEs) 1 , 28-9, 48, 106, 111, 124, 139, 140, 153-5; industrial restructuring and corporate governance 11-26; restructuring 219

steel industry 22

Supreme People's Court: Beijing 52 swine industry 215,223

Taiwan 34,39

tariff reductions: and endogenous productivity 202-7; industry results 203-4; macroeconomic effects 202-3; regional effects 205-6

tax-for-profit reform 19 tobacco processing industry 16 Tsai, K.S. 29

Tsingtao Brewery 46, 50, 54, 57

unemployment and employment: policy responses $6,124-38$

United nations 179

United States 201; National Association of Securities Dealers 59

Using Foreign Investment to Reorganise State-owned Enterprises Tentative Provisions 49

Vietnam 225
Wang Dongjin (Vice-Minister of Labour and Social Security) 127

Wang, X.: and Nolan, P. 18

Wang, Z.T.: and Xue, Y.G. 97

Wen Jiabao 10

Wenzhou city 29

Western China: GDP growth rate 217

White, G.: and Goodman, R. 161

Whiteford, P. 160

Wong, C.K. 145

workplace accident/injury insurance reforms 189-93; definition of work-related injury 190; limitations of coverage 1913 ; recent legislation 189-90; social pooling 190-1

World Bank 159, 200; Old Age Security: Pension Reform in China 159

World Health Organization (WHO) 178-80

World Trade Organization (WTO) 1, 2, 30, 48, 106, 137, 155, 192, 199-207; Global Strategy 181

WorldCom 3

xiagong (lay-off) reforms 6

Xiamen 187

Xinjiang Production and

Construction Corps 214

Xinjiang Uighur Autonomous

Region of China 214-15

Xue, Y.G.: and Wang, Z.T. 97

Zhang, Y. 217

Zhu Rongji 10

Zhuhai 187 


